\title{
THE ISSUES OF IMPROVING LEGAL KNOWLEDGE IN THE XXI CENTURY: THE UNITY OF THEORY AND PRACTICE
}

Collective monograph

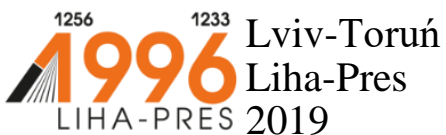




\section{Reviewers:}

Prof. dr hab. Sabina Grabowska, Uniwersytet Rzeszowski / University of Rzeszow (Republic of Poland);

Prof. dr hab. Joanna Marszalek-Kawa, Uniwersytet Mikotaja Kopernika w Toruniu / Nicolaus Copernicus University (Republic of Poland).

The issues of improving legal knowledge in the XXI century: the unity of theory and practice : collective monograph / V. Benkivsky, M. Burdonosova, O. Chepik-Trehubenko, O. Holovko, etc. - Lviv-Torun : Liha-Pres, 2019. $-260 \mathrm{p}$.

ISBN 978-966-397-164-3

Liha-Pres is an international publishing house which belongs to the category "C" according to the classification of Research School for Socio-Economic and Natural Sciences of the Environment (SENSE) [isn: 3943, 1705, 1704, 1703, 1702, 1701; prefixMetCode: 978966397]. Official website www.sense.nl. 


\section{CONTENTS}

THE EFFECT OF CAUSALITY ON SOLVING CRIMINAL LAW ISSUES

Volodymyr Benkivsky .......................................................................................... 1

RESEARCH OF PROFESSIONAL LEGAL CULTURE: METHODOLOGICAL ASPECT

Maryna Burdonosova

THE POLITICAL SYSTEM OF SOCIETY: FEATURES AND PROSPECTS OF DEVELOPMENT IN UKRAINE

Olha Chepik-Trehubenko

GENERAL REGULARITIES OF THE DEVELOPMENT

PROCESS OF THE HISTORY OF STATE

AND LAW ACCORDING TO THE DOCTRINE

OF GEORG WILHELM FRIEDRICH HEGEL

Oleksandr Holovko

TAXPAYER CRITERION AS A GROUND

FOR RECOGNIZING A LOCAL TAX RESIDENT

AND VOTER AT LOCAL ELECTIONS

Nataliia Iakymchuk

THE LATEST TRENDS OF ANNULMENT

OF THE COMMERCIAL ARBITRATION AWARDS

IN UKRAINE: GROUNDS, APPROACHES, CONSEQUENCES

Yuliya Kabrera .85

SYSTEM OF CONTRACTS FOR THE DISPOSAL OF INTELLECTUAL PROPERTY RIGHTS

Svitlana Mazurenko 109

STATE SYSTEM GUARANTEES: THEORETICAL AND LEGAL CHARACTERISTICS

Larysa Nalyvaiko 
RISK AS A MENTAL ELEMENT OF CIVIL LIABILITY

OF POLICE OFFICERS IN UKRAINE

Olha Panchenko

WAYS TO INTERPRET TAX LEGISLATION

Igor Samsin. 166

MULTICULTURALISM:

A HUMAN RIGHTS-BASED APPROACH

Vitalii Serohin 185

PROFESSIONAL AND ETHICAL STANDARDS

FOR CIVIL SERVANTS OF INTERNATIONAL

INTERGOVERNMENTAL ORGANIZATIONS

Tetiana Syroid 201

SOCIAL AND LEGAL SUPERVISION AND CONTROL FOR COMPLIANCE WITH FACTORY LEGISLATION

IN SCIENTIFIC VIEWS OF THE LATE XIX EARLY XX CENTURY

Halyna Terela

TERRITORIAL BOUNDARIES

OF CRIMINAL JURISDICTION OF UKRAINE

Oleksandr Zhytnyi 


\section{THE EFFECT OF CAUSALITY ON SOLVING CRIMINAL LAW ISSUES}

\section{Volodymyr Benkivsky}

\section{INTRODUCTION}

The issue of causation and causation in the criminal law of Ukraine and other countries is quite urgent.

The importance of the study of causation in modern criminal law is confirmed by its legal interpretations both within the Criminal Code of Ukraine $^{1}$ and within the codified acts of other countries. In particular, it is possible to note the previous editions of the Criminal Code of Moldova, the current version of the Criminal Code of Georgia ${ }^{2}$, the Model Criminal Code of the USA. With regard to the Criminal Code of Ukraine, the modeling of causality in the Criminal Code is a promising and possible way (tool) for accurate resolution of issues of criminal law evaluation.

Problems in criminal law were investigated in the scientific works of such scientists as M. Bury, I. Crees, A. Feuerbach, F. List, N.S. Tagantsev, V.I. Kofman, M.I. Kovalev, T.V. Tsereteli, A.A. Piontkovsky, T.L. Sergeeva, V.M. Kudryavtsev, M. Brainin, M.D. Shargorodsky, A.V. Uspensky, P. Leyland, V.B. Malinin, E.V. Fesenko, A.A. Muzyka, S.O. Efremov, S.R. Bagirov, O.L. Tymchuk and others.

In part, as part of the study of the differentiation of liability for negligent crimes, issues other than causal deterministic dependence were considered in the collective paper A.A. Muzyky and S.R. Bagirov's "Causal Connection: Criminal Law Outline" (2009).

However, at the dissertation and monograph level, only some criminal issues of causality were investigated; as a rule, the problem of causality in the context of modern criminal justice research was considered rather schematically.

In particular, scientists point out the difference between functional and causal relationships; temporal connections from causal; causal relationship relationships and more.

${ }^{1}$ Tatsiy V.Ya., Pshonka V.P., Borisova V.I., Tutyugina V.I. (eds.) (2013) Kryminaljnyj kodeks Ukrajiny: Naukovo-praktychnyj komentar. 2 t. [Criminal Code of Ukraine: Scientific and Pracrical Commentary, vol. 2]. Kyiv, p. 1040.

${ }^{2}$ Bigvava Z.K. (2002) Ugolovnyy kodeks Respubliki Gruzii [The Criminal Code of Georgia]. St. Petersburg: Law Center Press, p. 409. 
At the same time, there was almost no required institutional analysis within the framework of criminal law institutions.

The purpose of this study is to conceptually characterize the theory and legislative reflection of causation in criminal law. Within the framework of this study, it is necessary to pay attention to specifying the scientific provisions of the research topic; in particular, it is important to study the various aspects of the formation of modern approaches to the study of causation within Ukraine ${ }^{3}$ and abroad.

\section{Theoretical aspect of causation analysis in criminal law}

The notion of connections in philosophy forms the methodological basis for their implementation in criminal law.

The concept of connection (connections) in philosophy is at the same time justifying the emergence of fundamental philosophical approaches: dialectics, metaphysics, hermeneutics, etc.

The concept or conceptus ${ }^{4}$ in philosophy is a definite, generalization of the most characteristic features, features of a scientific object that reflects a real phenomenon.

The concept of "connection" in philosophy meets the criteria of logical scope and content of the concepts of "relation", "correlation"; by a criterion that can be described as a method or form of implementation, it is related to the concepts of "activity", "system", etc.

Yes, it is doctrinally obvious that the concept of "connection" in its ontological characteristics (real justification) are adjacent to the concept of "relation", which is the moment of interaction of phenomena, objects.

Within the general theory of systems, the founders of which are considered to be the founders of A. Bogdanov and L. von Bertalanffy, the system is described in particular as the set of certain elements between which there is a natural connection or interaction ${ }^{5}$.

These philosophical notions of connection underlie the notion of causation as being characterized by temporal (cause preceding in time of consequence) and genetic asymmetry (cause produces consequence, consequence does not cause).

3 Baulin Yu.V., Buromenny M.V., Golina V.V., Grishchuk V.K., Zaichuk O.V., Navrotsky V.O., Naden O.V., Nikitin Yu.V., Onishchenko N.M., Kharitonova Yu.V., Shakun V.I. (2015) Suchasna kryminaljno-pravova systema v Ukrajini: realiji ta perspektyvy [Modern criminal and legal system in Ukraine: realities and prospects]. Kyiv: Vaite, p. 688.

${ }^{4}$ Filosofskiy slovar' (2006) [Philosophical dictionary]. Kyiv: A.S.K., p. 439.

${ }^{5}$ Danilyan O.G., Taranenko V.M. (2012) Filosofiya: uchebnik [Philosophy: Textbook]. Kharkov: Right, p. 229. 
The modern concept of causality implies its modified characteristic as the interaction of phenomena. This somewhat explains the typical concept of cause and effect, as one-sided, asymmetric, within which the cause is generative or distinct. In the modified approach, causality is the connection between objects and phenomena, which is formed by the transfer of action from one object or phenomenon to another (others). However, this view is not about criminal law, but criminology

Generally, within the characteristics of causality and causation, the following provisions are postulated:

1) there is a preliminary assumption that causality is universal, that is, every event has a cause;

2) monotony: the same causes produce the same consequences;

3) temporal asymmetry: the consequence in time always follows for (after) reasons;

4) genetic asymmetry, which, as noted earlier, is somewhat complemented by the possibility of an inverse effect of a consequence (a generating factor) on the cause (in the classical sense, a generating factor).

It should be noted that in addition to the cause, other sub-causal factors (excuse, incentives, circumstances) are of particular importance not to criminal law (solving its problems) but to criminology and psychology; in criminal law, these sub-causal factors are taken into account indirectly, and usually when the stage of criminal procedural implementation of the normative prescriptions of criminal law comes.

The subjective sub-causal factor "motive" is considered as an addition to the characteristic of the behavior of a person considered in criminal law, and in the criminal procedural aspect contributes to a negative result, and in the procedural - substantiates the result.

Within the causality methodology, the following can be stated:

1) the category "connection" is correlated with other categories ("interaction", "system", "structure");

2) it can be argued that causality is the most common form or type of communication that is considered by criminal law;

3) the causal manifestation of the determination must be considered within the framework of the current system of scientific knowledge, modified to take into account relatively new and recent ideas about the functional role and content of causation.

The considerable "specific gravity" of the use of causation in law, in particular in criminal law, is due to the fact that the clarification of causation provides a legal (normative) description or characterization of acts, the commission of which gives rise to certain legal consequences, related to the structure of communication ("cause-and-effect"). 
The latter means that the link has a generalized form: cause-and-effect. But as part of a systematic and meaningful study of causal communication, a number of problems arise, as schematically noted above. The first of these is to establish the limits of causality for law, criminal law. The second is to determine the nature of the effect of the consequence on the cause that can be used in the analysis of causality, which has legal significance.

A separate problem of causality is the delimitation of the so-called "natural" causality from the "social".

"Natural" causality is considered within the limits of natural processes (physical, chemical and similar in nature); "Social" causality is related to the field of social sciences, including with a right, a criminal law. The peculiarity of "social" causality, in particular, lies in the specific mechanism of causing, causing significant and harmful (formally prohibited, punished) consequences.

Methodologically, it is also important to determine the criteria for establishing the true cause of a particular phenomenon and consequence.

In terms of the formal-logical interpretation of causal communication, the formal-logical approach is well-developed and widespread in science.

In particular, this conclusion is based on the existence of such a component of logical science as the logic of causality.

The prerequisites for the emergence of logic of causality are the notion of cause, effect, and causation as a one-sided relationship within which the decisive role is played (exercised) by the cause.

It should be noted that the logic of causality is considered as a special part of philosophical science and a component of logic.

The problem of causality logic is usually considered at the "intersection" of philosophical and logical approaches to understanding causality.

These approaches were implemented within the scientific developments of the famous English scientists F. Bacon and J.S. Mill. In particular, they are known for their ideas in terms of logical interpretation of the concepts of "cause", "causal basis" through the concept of conditions (conditions), which were considered (collectively) as a logical basis for interpretation, prediction of occurrence and logical justification of the result.

The scientific approach developed by these scientists is applied both within the limits of modern formal and logical approaches of understanding of causality, and for solving problems of law and criminal in particular. The purpose of the Bacon-Mill method: the logical demonstration of whether one can consider the previous phenomenon to be the cause of the following ${ }^{6}$.

\footnotetext{
p. 347.

${ }^{6}$ Konversky A.E. (2016) Loghika: pidruchnyk [Logic: a textbook]. Kyiv: Kyiv University,
} 
In this connection, it is worth paying attention to the application of logicalphilosophical approach. J.S. Mill, representatives of the German classical school of law in the development of the theory of causality conditio sine qua non.

A logical interpretation of causality as an objectively existing dependence of phenomena is possible because, in the opinion of specialists in the field, this dependence is characterized by logical content or can be analyzed by logic. As noted, within the logic of causality for causation and causation, the following statements are true:

1) nothing is cause of oneself;

2) if one event is the cause of the second, then the second is not the cause of the first;

3) the same event cannot be both the reason for the presence of an event and the reason for its absence.

Implementation to these prerequisites is concentrated in the causal implication $(A \rightarrow B)$.

In addition, causal logic, as noted in scientific doctrine, is constructed in such a way that the full and incomplete causes were investigated (established).

The combination of these provisions of the logic of causality (causal logic) with the idea of a sufficient basis for the onset of a certain result, which can take a logical form (statement, judgment) has a constructive, that is, necessary to solve the problems of a particular system of scientific knowledge, character.

It should be noted that in formal logic to characterize the dynamics of causal influence is applied not the concept or terminology of philosophical ontology (that is, causation, conditioning), but its special-logical interpretation: "implication".

Formal logic, being applied to solve specific scientific problems, in particular criminal law problems, becomes the logic of scientific research, in particular, the research of causation in criminal law.

Of particular importance in the logical interpretation of causation is the notion of a complete and incomplete cause.

The full reason, as the set of necessary and sufficient conditions for a certain logical result and the notion of an incomplete cause, are of somewhat controversial (ambiguous) importance for use in criminal law evaluation.

Analysis of causal, criminal and legal manifestations (causal relationship as a sign of the objective side; causal connection of the crime and its serious consequences, etc.) allows to make a conclusion regarding the emergence of the problem of the relationship of concepts "full reason", "incomplete reason" with the important, from the author's point of view, the notion of "reason enough". 
The application of a logical idea and the notion of a full cause in criminal law complicates the requirements for a lawyer (qualified, competent lawyer) to find out; in particular, the characteristics of an act that has a criminal law value and causes a criminal offense, harm.

The notion of incomplete cause (taking into account only the necessary conditions of a conceivable logical result) raises the problem of the degree of completeness or incompleteness of the cause in its criminal law interpretation.

Therefore, from the author's point of view, dominant in criminal law is the notion that there is sufficient cause for a criminal offense to occur.

This reason must be such that it can be taken into account criminal law interpretations and assessments.

In regard to the resolution of criminal issues, it is advisable to consider formed on the basis of theoretical generalizations and practical legal activity of the concept of "sufficient cause", which is established in the course of criminal law assessment.

The notion of a full cause makes it possible to identify issues sufficient, which can be considered in the criminal law interpretations of the cause.

Schematically: $P \rightarrow Q$, where $P$ is the set of necessary and sufficient conditions and $Q$ is the result.

With incomplete reason, only the necessary conditions of the result are available, but there are no sufficient ones.

A separate part, within the logical interpretation of causality, form, in terms of the author, the prerequisites for the logic of causality.

The prerequisites for the logic of causality can, from the author's point of view, be constructed in the following sequence:

1) logical operations;

2) terms (logical terminology);

3) Logical and technical means: symbols, logical "icons" used for the logisation of specific scientific operations, processes.

The prerequisite for causal logic and logical interpretation of the causal link under the conditional name "logical operation" is a set of operations accepted in formal logic, reflecting typical ways of thinking of man. These include: implication, conjunction, and disjunction.

Implication (logical operation "implication") can be considered as a logical form of causing (causing) or conditioning the result, regardless of ontological or epistemological approaches to understanding causality; schematic: " $a \rightarrow b$ ", where $a$, what follows the assertion (conclusion, result) $b$.

However, it should be noted that "real" causation cannot always be consistently described by "implication"7 . Example, logical statement: "If the

7 Toftul M.G. (2012) Loghika: slovnyk-dovidnyk [Logic: dictionary-directory]. Kyiv: Academy, p. 118. 
roof is wet, then the rain has passed". The real reason for the "wet" roof is rain; however, the logical cause of the event is the "wet" roof, from which it follows that the rain has passed. That is, "real" and "logical" causality are correlate as a "mirror" inversion.

The ratio of "mirror" inverse dependence (or "mirror" position of the object) is referred to as "inversion".

In connection with the formal and logical study of causation in criminal investigations of causation issues, the definition of is given. J.S. Mill views reason as a set of necessary and sufficient conditions (combined by the concept of "equivalence").

View of J.S. Mill the conditions was supported by K. Birkmeyer; $\mathrm{K}$. Binding believed that the reason arises when positive conditions prevail over negative ones ${ }^{8}$.

\section{Some aspects of the mapping of causal link in the criminal law of the continental and Anglo-Saxon countries}

According to the author, the legal mapping of cause and effect causality is based on the assertion that if the perpetrator implies the development of events then he is criminally responsible?

It should be noted that the main criterion in the comparative-normative study of causality is not the belonging of the law to a specific legal family, but the degree of regulatory explanation of causality in the laws of countries. Accordingly, a certain sequence of comparison is determined based on the specified criterion.

It should also be noted that the degree of regulatory explanation of causality in foreign criminal justice systems and in Ukraine has certain features that characterize causality in the complex of legal justification of a person's criminal liability.

The mapping of causality in the Common Criminal Code, attests to the special role of causation in the justification of criminal liability (the Criminal Code of Georgia, the United States (Model Code), San Marino, etc.).

It should be noted that criminal law and legislation in most countries (both continental and Anglo-Saxon legal systems) do not provide for a causal link (given the importance of this procedure - regulatory regulation).

As a rule, when characterizing a crime in the initial sections ("Books"), the punitive consequence of the crime is emphasized or the subject's guilt is emphasized for committing an act provided for by the criminal law of the

\footnotetext{
${ }^{8}$ Shargorodsky M.D. (2003) Izbrannye raboty po ugolovnomu pravu [Selected criminal law works]. St. Petersburg: Law Center Press, p. 434.

${ }^{9}$ Leyland P. (1996) Kryminaljne pravo [Criminal law]. Kyiv: Foundations, p. 41.
} 
countries; a consequence of the foregoing is that causation is not regarded as a material basis for criminal (criminal) liability; the classic version of the material cause in this case involves the scheme of the form "standardization of crime (with emphasis on its harm) - standardization of causation in a separate article of the General Part (Code, Books) - causation as a mandatory enforceable element and a condition of criminal liability".

It is also possible to draw a preliminary conclusion, based on the analysis of foreign criminal law, that causality (causation) is considered as the moment of legal evaluation of actions.

In particular, for example, the Criminal Code of the Republic of Poland (ed. of 01/01/2016) contains a requirement to law enforcement agencies that the court takes into account when assessing the degree of harmfulness of an act:

1) the type and nature of the infringed good;

2) the amount of the damage caused ${ }^{10}$;

3) the amount of damage that could have been caused;

4) the manner and circumstances of the act.

From the above we can conclude that the crime is considered as an objectively harmful act; items 2,3 , which form the content of the requirement to evaluate the act of interpretation, can be considered as the presence in the Polish criminal (punitive) law of the following types of cause and effect:

a) communication of the type of "action-harm ("real" consequence)";

b) communication of the type of "action-possible harm" or, interpretatively, the threat of harm.

Analysis of the criminal law of foreign countries on normalization of causality (in particular, causation) leads to the general conclusion about different algorithms, ways of its display.

In particular, there is a clear way in which causality in relation to relevancy (statutory characteristics, circumstances) is displayed in the form of regulation for law enforcement agencies; there is a way in which causation is revealed as a moment of criminal law of evaluation of an act (indication of harm, substantial harm, the possibility of harming the object of the attack).

The main goal of various ways of normalizing causal communication is to gain an understanding of the complex of differentiating punished and unpunished behavior of characteristics.

A separate way of normative display of causality is to create conditions for its interpretation within the system of criminal law.

This method, from the author's point of view, is used in the Criminal Code of Ukraine and most CIS countries. At the heart of the method is the idea of

${ }^{10}$ Menchinsky V.L. (ed.) (2016) Kryminaljnyj kodeks Respubliky Poljshha [The Criminal Code of the Republic of Poland]. Kyiv: OVK, p. 47. 
the necessary (regular) causal connection; consequently, causal connection is doctrinal-normative: the view of connection is viewed, in the view of the author of the study, as a certain doctrinal, axiomatic (does not need to prove that the necessary reason is legally significant).

At the same time, this doctrine of "axiomatic" causality can be regarded as a certain legal principle, the beginning of the assessment of the behavior of the subject, to resolve the issue of his criminal liability.

This principle is constantly "verified" and implemented through the Special Part of the Criminal Codes of the mentioned countries; the introduction of the concept of "material composition of the crime" confirms, from the author's point of view, the above.

In addition, it can be argued that the doctrinal-normative, axiomatic notion of causal connection is a benchmark for use by subjects of law.

In particular, in the Criminal Code of the Republic of Belarus from July 9, 1999 Art. 11 "Crime", is considered an act related to the occurrence of consequences; Art. 24 "Guilt in a crime not connected with the occurrence of consequences" in combination with the totality of material warehouses provided for by the Special Part of the said Code.

Interpretation of Part 2 of Art. 11 on the contrary (since "direct" is a characteristic of a minor act) allow us to emphasize causality (causality) at the theoretical and normative level of "crime" by establishing the legal position that the crime (as opposed to a minor action) causes significant harm.

The combination of the provisions of Art. 11 "Concept of crime" and paragraph 5 of Art. 67 ("grave consequences of a crime") provides for consideration of a connection (which is considered outside the composition of the crime) of the form of "crime-grave consequences".

Section II of the current Criminal Code of Ukraine ("Crimes against life and health"), because it contains varieties of murder (material depots), considers causations as an element of the legal constructs of crimes (Articles 115-119); other legal constructs of crimes related to life imprisonment contain specific or missing links (Article 129 "Threat of murder").

Section VI of the current Criminal Code of Ukraine ("Crimes against property"), in so far as it contains varieties of "selfish" crimes (material warehouses), contains causal links, and provides them within the limits of certain articles (Articles 185, 186, 189, 190 and some others).

The analysis of Section VIII ("Environmental Crimes") has the peculiarity (which is characteristic of the codes of individual foreign countries), which defines a specific kind of causal link: "acts-of-danger to objects protected by criminal law".

In the criminal law of other countries apply the concept of "threat", "the amount of harm that could have been caused" and others. 
Accordingly, for example, the legislation of the Republic of Poland interprets causation by focusing on "the amount of harm that could have been caused"; in the legislation of the Republic of Georgia - the action constitutes a "specific danger" in terms of the consequences.

In other sections of the Criminal Code of Ukraine of 05.04.2001, it is possible to distinguish certain legal constructs of actions containing as an element a causal link.

In particular, in this connection it is possible to distinguish Art. 286 of the Criminal Code of Ukraine (Section IX, "Crimes against Public Safety"), Art. 312 of the Criminal Code of Ukraine (Section XIII "Crimes in the Circulation of Narcotic Drugs, Psychotropic Substances, Their Analogues or Precursors, and Other Crimes against Public Health") and others.

Generalization of the peculiarities of normative fixation of causality in the criminal legislation of foreign countries is problematic to this day.

A separate "block" of comparative legal research related to clarification of theoretical issues and legislative reflection of the provisions of the theory of criminal law is the problem of interpretation and legislative consolidation of the activities of accomplices in parts of the criminal legislation of countries.

The analysis of this question leads to the general conclusion that the problem is solved.

However, problematic issues arise within the theoretical and legislative characteristics of the individual elements of complicity.

In particular, there is a distinction between incitement and provocation to commit crimes; determining the time of complicity and some other issues of criminal value.

It should be noted that the European legal tradition provides for detailed regulation of these issues.

At the same time, this regulation does not completely resolve the issue of delimitation of "role" complicity from group, as well as complicity from involvement, etc.

A separate problem related to the reflection of criminal phenomena in criminal law is the display (in some cases) of the so-called "adjudication", which (or the consideration of which) influences the criminal law evaluation of the action.

Prejudice as a criminal phenomenon, expressed in the concept of "pretrial", is envisaged in the legislation and law of some countries of the continental legal system.

Pre-eminence or re-assessment may be considered as a condition of:

1) criminal law evaluation of actions;

2) as a factor that gives rise to or is a condition for the occurrence of certain legal consequences against the person who committed the criminal offenses. 
In particular, it is a criminal law of the Republic of Belarus and some other countries.

It should be noted that the criminal law of some countries contains concepts that certain state institutions (in particular, such as legal commissions) propose to amend or abolish. These include causality-related notions, subcontracting, and more.

The study can be summarized in advance:

1) in both continental and Anglo-Saxon legal systems and the criminal law of the countries represented, historically formed causality theories have been applied; the peculiarity is a concrete situational modification of the approaches of the theories regarding the understanding and establishment of legally significant causal connection;

2) causation is generally considered, in the theory of criminal law, as a substantiating moment concerning the criminal liability of a person;

3) the causal link in the Anglo-Saxon legal system is "tied" to a courtspecific situation;

4) the effectiveness of causation as a condition of a person's liability depends on the normative fixing of its basic characteristics (defined doctrinally) in the General part of a criminal act ("Code", "Statute", etc.);

5) causality in theoretical and normative sense is a separate and not completely resolved problem if viewed through the methodology of comparing different types of criminal law and legislation;

6) causality (within the comparative approach) has its manifestations in such "loci" of the current legislation of foreign countries and Ukraine:

a) complicity in the crime;

b) preliminary assessment (if any);

c) crimes related to harming the victim.

In the Criminal Code of the Republic of Azerbaijan dated January 30, $1999^{11}$, Article 14 "The concept of a crime" contains part 14.2, which provides for the formulation of a minor act (also, which did not cause harm to the individual, society or state); Section VIII ("Crimes against the Person"), crimes related to harm to public relations, etc.

The following legal components of the Criminal Code of Ukraine, dated 05.04.2001, testify to the grounds for the interpretation of the causal link having a criminal legal value:

1) Art. 2 (the basis of criminal liability);

2) Art. 11 ("The concept of crime");

${ }^{11}$ Ragimov I.M. (ed.) (2001) Ugolovnyy kodeks Azerbaydzhanskoy respubliki [Criminal Code of the Republic of Azerbaijan], p. 325. Retrieved from: http://base.spinform.ru/ show_doc.fwx?rgn=2670 (accessed 11 October 2019). 
3) a combination of Art. 11 and item 5 of Art. 67;

4) Section II (Crimes against the life and health of the individual) in part;

5) Section VI ("Crimes against property") in part;

6) Section VIII ("Environmental Crimes");

7) other sections within which there are separate crimes containing causation.

With regard to Article 2 ("Ground of criminal responsibility"), in this case it is necessary to pay attention to the part of the wording of the first article: "The basis of criminal responsibility is the commission of a person of socially dangerous act...".

Obviously, a legal interpretation of the term "socially dangerous act" is needed; by analogy with the approach adopted in the Polish criminal law, in particular, attention should be paid to the harmfulness of the act (the properties of causing harm).

Accordingly, there is an initial opportunity to interpret a legally significant causal link.

Interpretation of Part 2 of Art. 11 and the provisions of the relevant articles of other criminal laws (criminal codes) lead to the conclusion the existence of acts that, although reminiscent of crime, are not such.

Combining the provisions of these articles with an indication of an increased degree of harmful acts constitutes a causal combination of these acts with particularly harmful consequences.

As already noted, Section II of the current Criminal Code of Ukraine ("Crimes against life and health") provides for causation as elements of the legal structures of crime (Articles 115-119); other legal constructs of crimes related to life imprisonment contain specific links or are not linked (Article 129 "Threat of Murder").

As already mentioned, section VI of the current Criminal Code of Ukraine ("Crimes against property") contains acts containing a causal link.

Similarly, the analysis of Section VIII ("Environmental Crimes") has the peculiarity (which is characteristic of the codes of individual foreign countries) that defines a specific kind of causal link: "acts-of-danger to objects protected by criminal law". The return to previous argumentation is driven by the importance of the issues analyzed in the study.

In the criminal law of other countries apply the concept of "threat", "the amount of harm that could have been caused" and others.

The laws of the "Visegrad Four" countries explain the cause-and-effect relationship with a focus on harm.

An analysis of the criminal law of both continental and Anglo-Saxon legal systems leads to the conclusion that causality (causal links) can be considered:

1) within the characteristics of the "complicity" institute; 
2) if there are cases or manifestations of a case-law and its influence on the resolution of the question of criminal liability of a person in the criminal justice systems of different foreign countries;

3) within the characteristics of the legal structures of individual crimes.

As already mentioned, within the Criminal Code of the Kingdom of Spain (adopted on 24/11/1995) $)^{12}$, articles characterizing intentional joint participation in the commission of a crime are published in the various "Books" of the above Code.

Article 17 of the said Code contains provisions on the agreement of two or more persons about the commission of a crime and its commission; Article 18 identifies incitement and provocation to commit a crime; Article 29 defines the time of complicity (causal temporality) at the same time or at the time before the crime.

Article 141 of the Criminal Code of the Kingdom of Spain defines the concepts of "incitement", "conspiracy", "proposal" (the term characterizing causation, connection conditioning).

Section 19 of Chapter 1 of the Criminal Code of Spain contains Art. 404-405, who are punished for abuse of office; Article 407, 408 of which is punishable by non-compliance with criminal prosecution obligations.

The following examples show, from the point of view of the author of the study, the existence of a correlation (causal correlation) between a person's competence and actions characterized as abuse.

In the Criminal Code of the Republic of Poland of 06/07/1996, in the General part, provided for Art. 18 which examines options for liability for a crime, depending on the nature of the crime:

1) performing a prohibited act on your own;

2) execution by agreement;

3) the responsibility of one who directed the commission of the criminal act by another person;

4) the responsibility of the person who used the addiction of the person and recommended the crime.

Item 2 can be interpreted as a manifestation of the correlation between the contracting parties; item 3 - correlation of the organizer with other accomplices; item 4 - exploit the situation or intentionally create such conditions when there is no other way than to commit a crime (communication is conditional).

Article 24 of the Criminal Code of the Republic of Poland provides for or defines the content of the behavior of such an accomplice as incitement:

\footnotetext{
${ }^{12}$ Menchinsky V.L. (ed.) (2016) Kryminaljnyj kodeks Korolivstva Ispanija [Criminal Code of the Kingdom of Spain]. Kyiv: OVK, p. 284.
} 
incitement, depending on the situation, can be considered as a cause (causation) or as a condition (then there is a conditional dependence that is causation).

Article 16 of the Criminal Code of the Republic of Belarus dated $09 / 07 / 1999^{13}$, gives a description of complicity and a list of role accomplices, which in many moments coincides with the provisions of Art. 26, 27 of the Criminal Code of Ukraine from 05/04/2001.

At the same time, a striking feature of the said Code is the presence of Art. 8 "Prejudice of a crime committed in the territory of a foreign country".

In particular, it is regulated (stipulated by law) that criminal convictions and other legal consequences of committing a crime in the territory of a foreign state are of criminal legal value for resolving the issue of criminal liability for a crime committed in the territory of the Republic of Belarus.

Section XIV of the Special Part of the Criminal Code of the Republic of Belarus, in particular, contains legal constructs that include as a causal link element; Article 455, 456 contain situations of abuse, excess or inactivity of "power" subjects.

As noted in such cases, there is a correlation between competence and actions that lead to injury, causing harm (as in the Criminal Code of Ukraine).

British criminal law contained the concept of "incitement"; the Law Commission recommended that the existing form of crime be "subjugated" and replaced with a serious crime; that is, in the Anglo-Saxon legal system one can study cause and effect, but it is mediated by judicial generalizations, decisions for each criminal episode.

\section{CONCLUSIONS}

The following conclusions are needed:

1) in both continental and Anglo-Saxon legal systems and the criminal law of the countries represented by them, scientifically sound grounds and preconditions are required for an in-depth understanding of the place and importance of causation in criminal law;

2) causation is considered in the theory of criminal law as a component of a criminal offense;

3) causality in the Anglo-Saxon legal system is established by lawyers taking into account specific criminal situations;

4) causation as a condition of criminal responsibility of a person depends on theoretical and situational interpretations adopted within the framework of criminal law systems of different countries;

${ }^{13}$ Lukashova A.I., Sarkisova E.A. (eds.) (2001) Ugolovnyy kodeks Respubliki Belarus' [Criminal Code of the Republic of Belarus], p. 312. 
5) causality in theoretical and regulatory sense is a separate and fundamental problem of criminal law and the solution of which depends on the perception of scientific approaches of scientists of different countries;

6) causations (within a comparative approach) have common features both within the theory and law of the continental and Anglo-Saxon countries.

In conclusion, it should be noted that theoretical analysis and legislative reflection of complicity are promising in the study of theory and legislative reflection of causation.

In particular, within the framework of the Institute of complicity (Articles 26-31 of the Criminal Code of Ukraine) a typical causal link between the acts of accomplices in the commission of a deliberate crime and a criminal result is recorded; relevant articles of foreign criminal codes are similarly interpreted or interpreted.

\section{SUMMARY}

The article deals with the problematic issues of theory and the legislative display (fixation) of causality, which is of criminal legal value.

Methods of establishment and specific ways of displaying causal link in criminal law are considered.

The methodological bases of causation are analyzed, which should be considered within the basic level of understanding of cause and effect. Formal and logical grounds for understanding and analyzing causation in criminal law are considered.

It is stated that logical ideas about the implication, the full and incomplete basis (cause) are the basis of separate theories of causation in criminal law.

Various ways of reflecting causation and its characteristics in the criminal law of the countries of continental and Anglo-Saxon legal systems are considered.

The definition of legislative "loci" or those legal institutions within which are considered manifestations of causality.

Particular attention is paid to such components of criminal law as "complicity", "prejudice" and others.

At the level of specific crimes (offenses), within the framework of the legislative display of causation, attention should be paid to crimes related to harming victims.

\section{REFERENCES}

1. Tatsiy V.Ya., Pshonka V.P., Borisova V.I., Tutyugina V.I. (eds.) (2013) Kryminaljnyj kodeks Ukrajiny: Naukovo-praktychnyj komentar. 2 t. [Criminal Code of Ukraine: Scientific and Pracrical Commentary, vol. 2]. Kyiv, p. 1040. 
2. Bigvava Z.K. (2002) Ugolovnyy kodeks Respubliki Gruzii [The Criminal Code of Georgia]. St. Petersburg: Law Center Press, p. 409.

3. Baulin Yu.V., Buromenny M.V., Golina V.V., Grishchuk V.K., Zaichuk O.V., Navrotsky V.O., Naden O.V., Nikitin Yu.V., Onishchenko N.M., Kharitonova Yu.V., Shakun V.I. (2015) Sucнаsna kryminaljno-pravova systema v Ukrajini: realiji ta perspektyvy [Modern criminal and legal system in Ukraine: realities and prospects]. Kyiv: Vaite, p. 688.

4. Filosofskiy slovar' (2006) [Philosophical dictionary]. Kyiv: A.S.K., p. 1056.

5. Danilyan O.G., Taranenko V.M. (2012) Filosofiya: uchebnik [Philosophy: Textbook]. Kharkov: Right, p. 229.

6. Konversky A.E. (2016) Loghika: pidruchnyk [Logic: a textbook]. Kyiv: Kyiv University, p. 391.

7. Toftul M.G. (2012) Loghika: slovnyk-dovidnyk [Logic: dictionarydirectory]. Kyiv: Academy, p. 312.

8. Shargorodsky M.D. (2003) Izbrannye raboty po ugolovnomu pravu [Selected criminal law works]. St. Petersburg: Law Center Press, p. 434.

9. Leyland P. (1996) Kryminaljne pravo [Criminal law]. Kyiv: Foundations, p. 207.

10. Menchinsky V.L. (ed.) (2016) Kryminaljnyj kodeks Respubliky Poljshha [The Criminal Code of the Republic of Poland]. Kyiv: OVK, p. 138.

11. Ragimov I.M. (ed.) (2001) Ugolovnyy kodeks Azerbaydzhanskoy respubliki [Criminal Code of the Republic of Azerbaijan], p. 325. Retrieved from: http://base.spinform.ru/show_doc.fwx?rgn=2670 (accessed 11 October 2019).

12. Menchinsky V.L. (ed.) (2016) Kryminaljnyj kodeks Korolivstva Ispanija [Criminal Code of the Kingdom of Spain]. Kyiv: OVK, p. 284.

13. Lukashova A.I., Sarkisova E.A. (eds.) (2001) Ugolovnyy kodeks Respubliki Belarus' [Criminal Code of the Republic of Belarus], p. 312.

\section{Information about the author: Volodymyr Benkivsky, $\mathrm{PhD}$ in Law,}

Chair of Criminal Law and Criminology, Taras Shevchenko National University of Kyiv

10a, Hnata Yuri str., Kyiv, 03148, Ukraine ORCID ID: orcid.org/0000-0003-4830-8322 


\section{RESEARCH OF PROFESSIONAL LEGAL CULTURE: METHODOLOGICAL ASPECT}

\section{Maryna Burdonosova}

\section{INTRODUCTION}

There are radical quantitative and qualitative changes taking place in modern Ukrainian society. In order for legal, political and administrative reforms that are taking place in our country not to "skid", but to realistically influence society and produce a positive result, it is necessary to take into account the level of legal consciousness and legal culture of the social groups to which these radical changes are directed. First of all, there is the question of researching the professional legal culture of lawyers. These categories of persons on a professional basis are called to engage in the implementation of the rules of law. Lawyers must ensure the normative regulation of social activity in accordance with the legal rules and requirements of law.

Revealing the nature of professional legal culture requires the use of the proper scientific instruments capable of guaranteeing adequate and reliable result. The basis of scientific knowledge is rationality preferring not feelings and emotions, it based on logic principles produced and proven over the centuries. It's about principles and methods of research, methodology in general. Each new stage of the progressive development of scientific intelligence is related to the further increasing importance of methodology. The study of issues of professional legal culture depends on the level of development of problems of methodology of research of legal phenomena in the life of society and lawyers, in particular ${ }^{1}$.

The dialectics of any scientific knowledge is expanding and deepening the issue under development causes rethinking and analysis at a new, higher level, baseline data and research background ${ }^{2}$. And the legal field is no exception for such approach of dialectics. Development of the methodology of professional culture can realize a significant contribution to the theory of legal culture and culture in general. Before modern researchers in the field of legal deontology, theory of state and law, legal psychology, legal culture, there are questions of

${ }^{1}$ Kerimov D.A. (2011) Metodologiia prava: Predmet, funktsii, problemy filosofii prava [Methodology of law: Subject, functions, problems of legal philosophy] (6th ed.). Moscow: Publishing House of the SGU, pp. 60-61. (in Russian).

${ }^{2}$ Sokolov N.Ya. (2014) Professionalnaia kultura yuristov. Poniatie. Sushchnost. Soderzhanie [Lawyers professional culture. Concept. Essence. Contents]. Moscow: Prospect, p. 52 (in Russian). 
complex analysis of the relationship between legal knowledge, legal awareness, legal action and implementation of law.

The purpose of this disquisition is scientific and theoretical analysis of methodological issues of research of the professional legal culture of lawyers. This is done by identifying the following tasks: - identify the specifics of the methodology of the study of legal culture; - to identify methodological features of research of the professional culture of lawyers; - to formulate particular qualities of using some methods of study of professional legal culture.

Various aspects of the study of professional legal culture have been considered in legal literature by such scientists as: Anufrienko O.A., Bezborodyi V.O., Vengerov A.B., Groshevyi Yu.M., Ilyin I.O., Kozyubra M.I., Kotiuk V.O., Onishchenko N.M., Orzikh M.V, Sokolov M.Ya., Slivka S.S. and others.

The methodology of law was analysed by such scientists as: Alekseev S.S., Baranov V.M., Bandura O.O., Bryzgalov A.I., Gusarev S.D., Kazimirchuk V.P., Kerimov D.A., Kresin O.V., Krizhanovsky A.F., Lapayeva V.V., Oborotov Y.M., Pershin V.B., Polyakov A.V., Rabinovych P.M., Radko T.M., Selivanov V.M., Serdyuk O.V., Syrykh V.M., Skakun O.F., Tarasov M.M., Tykhomyrov O.D. and others.

Despite the significant contribution of these and other scholars to the development of the methodological foundations of law and the professional culture of lawyers, it would be fair to emphasize that the question of their combination remained. Not sufficiently disclosed the analysis of methodological approaches to the study of professional legal culture and identification of their peculiarities in order to identify the most effective methods of comprehensive approach for new scientific advances in this direction.

\section{Methodological features of study of professional legal culture}

The importance of analysing methodological issues is related to the fact of increased role of law in the process of building a democratic, social, legal civil society. This formation places greater demands on the justification of basic methodological positions of scientific knowledge by legal scholars.

The modern stage of science progress is characterized by intense development of methodology problems, which characterizes all branches of scientific knowledge. Such intensity is explained first of all by needs of deeper and comprehensive knowledge of the complex processes of social life and prospects for its development. Interesting in this aspect is the thought of modern scientists that in our time in the legal science has developed a situation where the political and legal phenomena of the past could be 
adequately understood with the help of fundamentally new to legal science scientific methods ${ }^{3}$. Development of the methodology of professional legal culture will be able to make a significant contribution to the theory of legal culture. This, in turn, is the main structural unit of the general theory of state and law. In addition, modern legal science developed new techniques and methods of research, requires a clearer organization of the activities of legal scholars in order to effectively use the data they received in practice.

Such problems of the modern Ukrainian society as enhancing the legal culture of the society, reducing the level of legal nihilism, are simultaneously investigated by several separate scientists, independently of each other. However, it would be more appropriate to create a dedicated team of scientists who would concentrate their efforts to solve the problem promptly and effectively. The obstacle to the implementation of such interaction and communication between scientific lawyers is the lack of methodological developments in this area, as well as some doubts about in professional honesty of scientists and virtue of possible colleagues (fear of losing the results of the research or their assignment to third parties). It points on existence of certain limitations in the professional legal culture.

Furthermore, coordination and engagement in solving social and legal life problems acquires great importance. Contemporary Ukrainian reality sets new tasks before the science. And there is an objective need for the participation of legal scholar's teams in solving the problems of legal practice. First of all, it is relevant in solving the following issues: improvement of legislation; law enforcement activities; strengthening the rule of law in the state; formation of law and order; raising the level of legal culture of citizens. The demand to enhance the self-analysis of legal science is caused not only by the need to develop the theory itself, but also by the need to improve legal practice.

New scientific developments that affect practice put increased demands on the responsibility of legal scholars. Science must guarantee reliability of such recommendations. Therefore, the support of the prestige of legal science depends to a large extent on the objectivity of its judgments, providing guarantees of the reliability of scientific conclusions. In this regard, it is necessary to agree with Sokolov M., who argues that an important contribution of legal science in practice can be made by studying the laws and features of the formation of professional

${ }^{3}$ Chernetska O.V., Shilingov V.S. (2009) Yurydychna komparatyvistyka yak samostiyna yurydychna naukova dystsyplina [Legal comparative studies as an independent legal scientific discipline]. Ukrainian Greek International Scientific Law Journal "Comparative Legal Studies", 2009, vol. 1, p. 26. (in Ukrainian). 
legal culture of different categories of legal practitioners. Professional legal culture development will prevent possible deformation of legal consciousness and legal nihilism ${ }^{4}$.

Another reason for the appeal to the issues of methodology of legal science is essential to enrich it with new tools of research, the increasing involvement of funds, which were previously used by such sciences as mathematical logic and information theory. In particular, widespread among legal scholars method of sociological research, use of computer technology and Internet requires clarification of conditions for their adaptation in the field of law and influence legal science. Immediate accumulation scientific knowledge must be accompanied by knowledge of the science of special theoretical principles and methods of analysis. New knowledge should be evaluated not only the classical methodological tools, but also should facilitate the search for new approaches to their study ("new to new") that meet the needs of modern society. Legal science can solve new practical problems that arise exactly in our society.

One of such important social "orders" for legal scholars is to create a social-psychological portrait of a modern lawyer. In the existing scientific researches, the legal culture of specific professional groups, such as judges, prosecutors, police officers, heads of internal affairs bodies, has been considered to a greater extent. In support of this, more general philosophical and legal studies in this area have been initiated ${ }^{5}$. It should be noted that the issues of elucidation of the general laws of formation and development of professional legal culture of modern lawyers remain insufficiently covered. That's why it requires the development of the methodological component of such research.

Besides, it should be considered that the problem of professional legal culture has dual nature. The study of the professional culture of lawyers should take into account dual legal categories and concepts. In addition, the scientific apparatus includes the legal concepts of "right", "law", "duty", "responsibility", "social and legal order", "justice". It is necessary to apply also cultural, sociological, psychological concepts and categories, such as

\footnotetext{
${ }^{4}$ Sokolov N.Ya. (2014) Professionalnaia kultura yuristov. Poniatie. Sushchnost. Soderzhanie [Lawyers professional culture. Concept. Essence. Contents]. Moscow: Prospect, p. 54 (in Russian).

${ }^{5}$ Slivka S.S. (2002) Filosofsko-pravovi problemy profesiinoi kultury yurysta [Philosophical and legal issues of professional culture of lawyers]. (PhD Thesis), Kharkiv: National Yaroslav the Wise Law Academy of Ukraine, pp. 4, 9-11.

Chuprinsky B.O. (2010). Formuvannia profesiinoi kultury maibutnih yurystiv: filosofskopravove doslidzhennia [Formation of professional culture of future lawyers: philosophical and legal research]. Extended abstract of candidate's thesis. Lviv: Lviv State University of Internal Affairs, pp. 5, 9. (in Ukrainian).
} 
"values", "traditions", "social group", "activity" and "behaviour". So we can argue that this phenomenon is an integrative idea, which is located on the cutting edge of legal science, cultural studies, sociology, and psychology. Enumerated science from different points of research analyse the issues of legal consciousness of those who must defend the law in society.

Considering dual nature and interdisciplinar peculiarity, the most appropriate methodological construction of the legal culture study is as follows: 1) based on the laws and categories of dialectics, 2) using general scientific methods of legal science, 3) take as a basis the theoretical and legal categories, ideas, concepts of the laws of legal science and special scientific methods, 4) apply cultural studies, sociological, psychological concepts and categories.

The professional legal culture of lawyers is a complex concept and is interdisciplinary. In order to fully explore such phenomena it is necessary to use achievements of sciences:

- Sociology (concepts as social groups and subjects), since we reserch specific social group - lawyers, subjects united by a single profession;

- Cultural studies, namely, the concept of traditional values of a particular society, wich lawyers must protect;

- Psychology in particular, concept of activity and behaviour, which is the basis for distinguishing between legal and illegal actions and criminal behaviour;

- Jurisprudence, namely with the correlation of right and law, which is the basis of legal culture.

The interdisciplinary nature of the study of professional legal culture causes the emergence of special phenomena that arise at the intersection of the indicated areas. Therefore, to assess the level of such culture among lawyers, resercher should consider the presence of such qualities as:

- Sense of social justice and an awareness of the need to protect it as a representative of a profession based on this principle, Lady Justice (from latin: Iustitia) is an allegorical personification of the moral force in judicial systems;

- Internal responsibility for their actions and decisions combined with a sense of professional duty;

- Level of development of legal consciousness;

- Understanding the value of the legal order, ensuring the conflict-free existence of society (scheme 1).

\footnotetext{
${ }^{6}$ Burdonosova M.A. (2015) Metodolohichni osoblyvosti doslidzhennya profesiynoyi kultury yurystiv [Methodologocal features of reserch of professional culture of lawyers]. Public law, vol. 4(20)/2015, pp. 261-266. (in Ukrainian).
} 


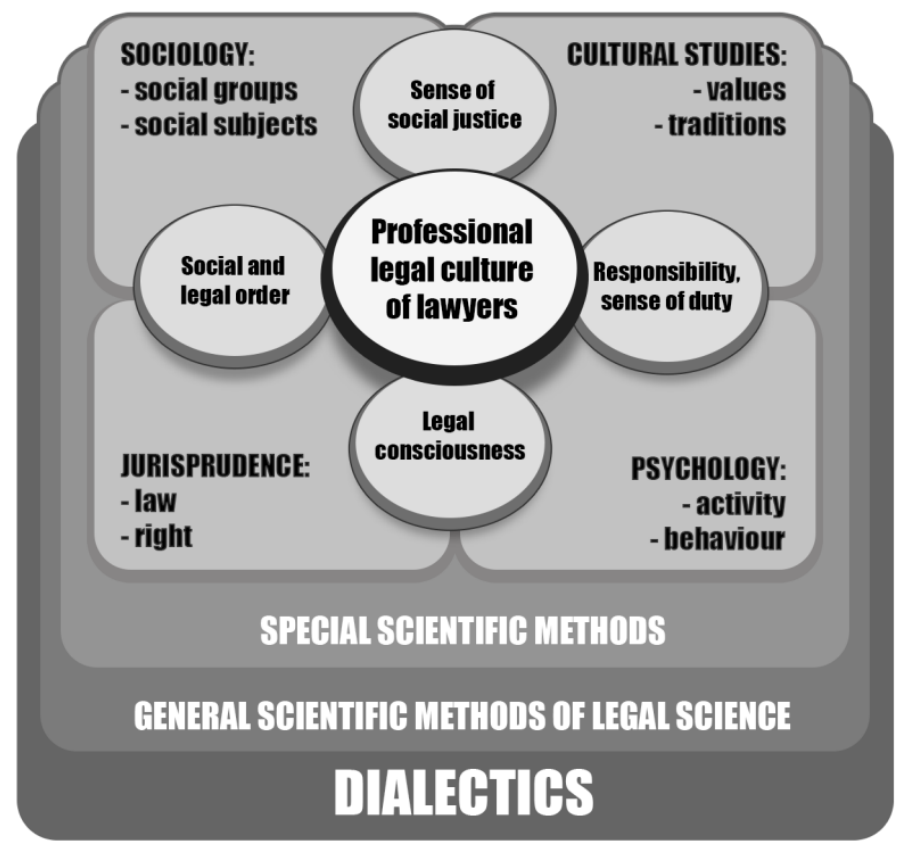

\section{Scheme. 1. Methodological construction of study of the professional legal culture of lawyers}

The problem of synthesis of legal and cultural concepts needs special attention of the researcher, as wel as their combination into united complex. Also, it would be advisable to apply a comprehensive, integrative approach to the study of the professional culture of lawyers. Taking this ratio into account will prevent unnecessary legitimization of the results of the study and at the same time avoid significant distortions towards cultural studies or psychology.

According to systematic approach the methodology of scientific knowledge is a system of different levels based on common methods of thinking (analysis, synthesis, abstraction, generalization, induction, deduction, analogy and modeling) ${ }^{7}$. And also, agreeing with Kazimirchuk V.P., that methodology of legal science is the application of a system of logical

${ }^{7}$ Yudin E.G. (1978) Sistemnyi podhod i printsip deiatelnosti. Metodologicheskie problem sovremennoi nauki [Systematic approach and the principle of action. Methodological problems of modern science]. Moscow: Nauka, pp. 41-44 (in Russian).

Gusarev S.D., Tykhomyrov O.D. (2010) Yurydychna deontologiia (Osnovy yurydychnoi diialnosti) [Legal deontology (Principles of Law): teach. guidances.] (4th ed.). Kyiv: Znannia, pp. 73-91 (in Ukrainian). 
techniques, special methods and methods of study of legal phenomena, which are determined by the theoretical principles of materialistic dialectics ${ }^{8}$. We can define the methodology for the study of the professional culture of lawyers, as, based on common methods of thinking, system of logical techniques, principles and methods of organization, construction and implementation of theoretical and cognitive activity in the field of professional legal culture research of various groups of lawyers.

It seems that the application of logical techniques, special methods and methods for the study of professional legal culture, which are determined by the theoretical principles of dialectics, will clarify the essence of the methodology of this phenomenon and reveal its vertical construction. Conducting research on specific types directs the researcher to the depth of horizontal construction of the system:

- At the level of philosophical methods, it is advisable to rely on the laws and categories of materialistic dialectics;

- At the level of general scientific methods - to apply systemic, synergistic, behavioral, structural, functional, method of comparison and modeling for legal "field";

- At the level of special scientific methods - to use interview, questioning and analysis of the answers of the professional-legal group, observation of the professional activity of lawyers, comparative, statistical, method of mathematical processing of results;

- At the level of specialized scientific methods - to work out the results of psychological methods of personality studying, different influences on it and checking the mental qualities of the lawyer's personality.

\section{Particular qualities of using some methods of study of professional legal culture}

Methods of researching the legal culture of lawyers are part of the methods of legal science. However researchers still need to study methods for solving a particular legal problem. A similar approach extends to the study of the diverse phenomena of professional legal culture.

The techniques of studying of professional legal culture include:

- Analysis of statistical data, official communications and documents, scientific literature, press appearances, radio and television, related to professional and legal activities;

${ }^{8}$ Kazimirchuk V.P. (1965) Pravo i metody ego izucheniia [Law and methods of its study [monograph]. Moscow: Yurydychna literatura, p. 44 (in Russian). 
- Methods of analysis of work of lawyers: observation, method of analysis of critical situations;

- Survey and analysis of group professional legal opinion;

- Psychological (social-psychological) methods;

- Interview and written surveys (questionnaires);

- Methods of mathematical processing.

Researching of legal culture of lawyers also involves two main ways. The first is related to the artificial isolation by the researcher some individual phenomenon of professional legal culture. For example, this is used in a laboratory experiment or simulation.

The second way is a "field research". Where the "field" is the natural space where the activity of the individual unfolds. The researcher's task is to organize the study with minimal influence on the natural conditions. Due to the specific nature of legal activity, compliance with this requirement is of fundamental importance. The influence of the researcher on the decision of legal workers of criminal and civil cases is inadmissible. This means that the principle of legality extends to the field of scientific study of professional legal culture.

1. Comparative method. This method is not just a certain system of thinking, that is, the sum of the criteria that must ensure that the right one is achieved result, but it is also a working method. Comparison in law is relatively independent, systematically organized a way of research in which comparison is necessary to achieve specific goals of cognition. A relatively legal study by comparisons systems discover the common and also finding out what different. Both tasks and opportunities are relatively legal research (establishing common and different in comparable objects) are also interconnected, both common and distinct in legal systems.

On the one hand, comparison involves establishing a commonality that can be detected only by the comparative method, and on the other - helps to distinguish between the compared objects. The comparative legal method is one of the important means of study legal phenomena. Thanks to its application it becomes possible to detect for general, particular and specific in the legal systems of the present day.

Criteria for comparative legal research should be considered in more detail. In this regard, it is important to identify decussate theories through which one can find the institutions and norms that belong to different legal systems, and they are so comparable, that this comparison is justified. The point of departure here is to use the same concepts and terms used in another legal system, and this has the effect of comparing related systems. Expanding the area for compared legal phenomena increases the risk of 
errors in process of searching for a foreign term that would correspond to the domestic one'.

Heterogeneous legal culture as well as the same type of professional legal culture can be the object of the comparative method. It can be applied not only to two or more legal systems or their structural components. We can use this method when organizing a comparative study of the professional culture of lawyers of various countries belonging to the European Union. This is relevant for the process of implementing European legal experience in the legal system of Ukraine.

At the same time, a comparative study of of professional culture of various groups of legal workers: judges, prosecutors, lawyers, notaries, legal advisers, police officers are of particular importance for increasing the level of their legal consciousness. Some components of a professional culture are difficult to determine without using a comparison method, for example, mutual evaluations of each other by different categories of legal workers. A comparison of professional legal culture allows more accurately establish its condition and develops scientific recommendations for practical legal institutions and bodies.

2. Systematic approach allows studying structure, functions, development of professional legal culture. It has cognitive capabilities, as well as the lack of use by legal scholars. The works in the legal literature, despite their great importance and deep theoretical content, can only be recognized as the beginning of a comprehensive study of legal phenomena.

Before using a systematic approach in the study of a particular legal object, it is necessary to estimate the possibility of considering the research object as a holistic system. System concepts are used very widely, sometimes even where they should not be used, where the application of a systematic approach is not dictated by scientific or practical necessity. That is why the consideration of a professional legal culture as a system should be justified by the choice of such an approach. Research on legal consciousness and legal culture is no exception. The issues of structure are given considerable importance. However, not always these studies in the full sense can be recognized as systemic. The notion of structure is used by their authors in a very broad sense, as a collection of elements and relationships. This resultis that the concept of structure identified with the concept of the whole. But more productive understanding of structure, in the narrow sense, as the

${ }^{9}$ Chernetska O.V., Shilingov V.S. (2009) Yurydychna komparatyvistyka yak samostiyna yurydychna naukova dystsyplina [Legal comparative studies as an independent legal scientific discipline]. Ukrainian Greek International Scientific Law Journal "Comparative Legal Studies", 2009, vol. 1, p. 27. (in Ukrainian). 
interconnecting and interacting parts of the whole. In the literature on the problems of the theory of legal culture, insufficient attention is paid to the analysis of the functional relations of the system of legal culture, the interaction of functions and structural elements, connection of legal cultural studies with practice.

Systematic approach allows combining analysis and synthesis, qualitative and quantitative in the study of social processes. This opens up great opportunities for the application of heuristic and logic-mathematical methods.

Professional legal culture can be considered as a relatively independent holistic system. It matches the requirements for holistic systems that are formulated in philosophical, cultural, sociological and legal sciences in the process of developing systemic problems in society, the state and law. An important result of these studies is the conclusion that systematicity is a universal attribute of matter and consciousness, but integrity is a specific property. Not all phenomena of reality have such specific property as systematicity.

The systematic nature of professional legal culture is the result of the systematic nature of the world around us, which acts as their inherent property. The legal culture, including professional, is systemic, since they reflect the legal reality. The systemic nature of legal reality naturally determines the systemic nature of the consciousness and culture reflecting and cognizing it, including professional level.

As noted by Sokolov N.Ya., professional legal culture matches all the requirements for holistic systems. These include: integrativity; the presence of the necessary connections between elements, components and the system; structurality (organization); purpose and expediency; functioning; control; development ${ }^{10}$.

The significance of a systematic approach to the study of professional legal culture is largely determined by the inextricable link of legal activity with management. In this area, such an approach was most developed and brought noticeable practical results. Research in this direction will further enhance the level of legal culture of legal personnel. The study of the system of professional legal culture can help improve the ways, means, methods and forms of increasing its level.

3. Statistical method studies the quantitative aspect of changes in the social life, processes the obtained results for the scientific and practical purposes of establishing and studying the quantitative characteristics of the

${ }^{10}$ Sokolov N.Ya. (2014) Professionalnaia kultura yuristov. Poniatie. Sushchnost. Soderzhanie [Lawyers professional culture. Concept. Essence. Contents]. Moscow: Prospect, 320 p. (in Russian). 
state-legal phenomena. Statistical surveys (for example, the number of normative acts regulating a particular relationship, the number of unsolved crimes) reveal some trends in the development of public relations.

Statistical method is one of the most powerful tools of social cognition. Social science cannot be based on random single data; the laws of the phenomena studied by it can be established only with mass statistical research. Statistical patterns are manifested in mass social processes, in aggregates of social objects consisting of a large number of units. They are formed in accordance with the law of large numbers. The simultaneous influence of a large number of random factors and causes leads to results that are almost independent of the case.

The law of large numbers is one of the basic laws used by statistics to study the phenomena of public life. It allows us to understand why, due to the large amount of random communication chaos, we can establish patterns in the development and trends of social phenomena. One or even a small number of cases in social life can give random, non-peculiar, overall indicators (for example, recidivists are usually people with low educational attainment, but some individuals with higher education may be identified).

Therefore, in the study of social phenomena, it is necessary to make mass observations, based on the law of large numbers. Otherwise, the conclusions drawn from a small number of facts can be misleading. Mass registration of facts and their research allow us to reject the accident, which may be inherent in individual manifestations and to determine the regularity contained in the totality of phenomena.

Statistical patterns express causal relationships that exist in the area of social phenomena and processes. Statistical patterns are also manifested in the field of professional legal activity, which allows us to make conclusions about the state of the professional culture of lawyers and identify factors that have a significant impact on it.

Material for the study of professional consciousness is provided by legal statistics characterizing the activities of various legal bodies and institutions for combating crime, statistical reports on the composition and movement of personnel of employees of the judiciary, court, prosecutor's office, etc. The same way data of criminal law and civil law statistics can be used to study professional legal culture.

The statistical method provides comprehensive, scientifically justified information on trends and patterns in crime development. The level of crime, the structure, the identity of the offender, the causes and conditions of the existence of crime, as well as the positive and negative consequences of the work of law enforcement agencies on its prevention can be studied on the basis of statistics. 
The statistical method plays a significant role in the legal process of coordinating the activities of different law enforcement agencies in order to overcome their fragmentation. Systematic study and use of legal statistics is necessary in order to increase the level of professional legal culture, improve personnel work in legal bodies. For example, the study of the causes of judicial errors will increase the efficiency of the judicial authorities, including the level reduction of offenses, participation in the legal education of citizens.

4. Modeling method is based on the theory of similarity. It is based on the assumption that one-to-one correspondences can be established between different objects; therefore, knowing the characteristics of one, resercher can to establish the other. The object, by monitoring which you can get an idea of another object, is called a model, and the research process based on this correspondence is called modeling.

In the modeling process, an analogue of the object under study is created, in our case, professional legal culture, or its components. Phenomens correlates of on the basis of "cause - effect". Modeling allows you to create informative situations, and not just wait for their occurrence. It is associated with the process, dynamics, development and search. Due to the ability of modeling to provide a compact organization of facts, it is able to more clearly demonstrate their relationship, which is not always possible in the process of establishing and describing them. The modeling method also has a significant prospect in the study of professional legal culture in the sense that it allows more widespread involvement of quantitative data into the analysis, the use of the mathematical apparatus, and the introduction of new variables ${ }^{11}$.

Before starting the modeling of the problem, an understanding of the structure of the object or its elements is necessary. If the structure of professional legal culture is defined, then the purpose of modeling is its functioning in different conditions. If the researcher of professional legal culture has information about the individual elements and functions of an object, then the purpose of modeling is its structure.

Modeling of professional legal culture corresponds to those tasks which are usually set before it. It is functionally essential to practice. Accordingly, the work of the model has a direct influence on practice. In the legal literature, it is correctly noted that one of the main advantages of this method is that it allows you to "simulate the activities of people involved in law, especially lawyers, in such important areas of public life as management, law-making,

${ }^{11}$ Brudnyi A.A. (1977) K probleme modelirovaniya v sotsialnoy psikhologii [To the problem of modeling in social psychology]. Metodologiya i metody sotsialnoy psikhologii. [Methodology and methods of social psychology]. Moscow: Nauka, pp. 86-95 (in Russian). 
and the administration of justice. It is of great importance for the use of cybernetic machines in law" 12 .

By analyzing the effect of the model, it is possible to find previously unknown structural and functional features of the object of modeling - the existing legal culture. In the course of the study of professional legal culture conducted by Sokolov, the significance of the stereotype of the criminal in the professional activities of a lawyer was established. It helps to determine in a preliminary, schematic form a plan for a possible solution to a particular case. Thus, when the model is correct and correctly reproduces the object under study, the researcher can move from it to the model, which begins to temporarily replace the object ${ }^{13}$.

With all the advantages of the modeling method, it has several disadvantages. Model-schemes have limited possibilities for influencing cognitive activity. Schemes alone cannot prove results; they can only illustrate the process if its individual elements are clarified theoretically.

Modeling, especially when the model has proved its efficiency, allows us to plan and conduct new observations and studies. For example, the model of the structure of professional legal culture is constant for studying the legal social and professional group as a whole. After making clarifying adjustments to it, it can be used to study the professional culture of different groups of legal workers.

\section{CONCLUSIONS}

One of important social "order" for legal scientists is to create social and psychological portrait of the modern lawyer. Enough questions remain illuminated clarify the general laws of formation and development of modern legal culture of professional lawyers, which in turn requires the development of methodological part of the study.

It should be considered that the problem of professional legal culture has dual nature. The study of the professional culture of lawyers should take into account dual legal categories and concepts. In addition to the fact that the scientific apparatus includes the legal concepts of "right", "law", "duty", "responsibility", " social and legal order", "justice". It is necessary to apply also cultural, sociological, psychological concepts and categories, such as "values", "traditions", "social group", "activity" and "behaviour".

${ }^{12}$ Kazimirchuk V.P. (1965) Pravo i metody ego izucheniia [Law and methods of its study [monograph]. Moscow: Yurydychna literatura, P. 163 (in Russian).

${ }^{13}$ Sokolov N.Ya. (2014) Professionalnaia kultura yuristov. Poniatie. Sushchnost. Soderzhanie [Lawyers professional culture. Concept. Essence. Contents]. Moscow: Prospect, P. 68. (in Russian). 
Considering dual nature and interdisciplinar peculiarity, the most appropriate methodological construction of the study of legal culture is as follows: - based on the laws and categories of dialectic; - using general scientific methods of legal science; - take as a basis the theoretical and legal categories, ideas, concepts of the laws of legal science; - apply cultural studies, sociological, psychological concepts and categories.

Profesional legal culture of lawyers is an integrative idea, which is located on the cutting edge of legal science, cultural studies, sociology, and psychology. Enumerated science from different points of research analyse the issues of legal consciousness of those who must defend the law in society. Methodology of the research of culture of professional lawyers is - based on the general methods of thinking, logical system techniques, principles and methods of organization, construction and implementation of epistemological research activities in the field of professional legal culture of various groups of lawyers who are involved in different areas of society.

Comparative study of of professional culture of various groups of legal workers: judges, prosecutors, lawyers, notaries, legal advisers, police officers are of particular importance for increasing the level of their legal consciousness. A comparison of professional legal culture allows more accurately establish its condition and develops scientific recommendations for practical legal institutions and bodies.

The significance of a systematic approach to the study of professional legal culture is largely determined by the inextricable link of legal activity with management. Research in this direction will further enhance the level of legal culture of legal personnel. The study of the system of professional legal culture can help improve the ways, means, methods and forms of increasing its level.

The statistical method plays a significant role in the legal process of coordinating the activities of different law enforcement agencies in order to overcome their fragmentation. Systematic study and use of legal statistics is necessary in order to increase the level of professional legal culture, improve personnel work in legal bodies.

Modeling of professional legal culture corresponds to those tasks which are usually set from practice. The main advantages of this method is that it allows to simulate the activities of people involved in law, especially lawyers, in such important areas of public life as management, law-making, and the administration of justice.

\section{SUMMARY}

The theoretical analysis of methodological questions of research of professional culture of lawyers is conducted in the reserch. For this purpose 
the specific of methodology is outlined and the methodological features of research of professional culture of lawyers are determined. Special methodological construction is offered for such research.

Development of the methodology of professional legal culture will be able to make a significant contribution to the theory of legal culture. This, in turn, is the main structural unit of the general theory of state and law. In addition, modern legal science developed new techniques and methods of research, requires a clearer organization of the activities of legal scholars in order to effectively use the data they received in practice.

Author defines the following problems: identify the specific research methodology of legal culture; identify methodological features of studies professional culture of lawyers; identify particular qualities of using such methods of study of professional legal culture as: comparative, systematic, statistical, modeling. On the basis systematic approach author defines understanding of methodology of research of professional culture of lawyers.

\section{REFERENCES}

1. Kerimov D.A. (2011) Metodologiia prava: Predmet, funktsii, problemy filosofii prava [Methodology of law: Subject, functions, problems of legal philosophy] (6th ed.). Moscow: Publishing House of the SGU, $521 \mathrm{p}$. (in Russian).

2. Sokolov N.Ya. (2014) Professionalnaia kultura yuristov. Poniatie. Sushchnost. Soderzhanie [Lawyers professional culture. Concept. Essence. Contents]. Moscow: Prospect, 320 p. (in Russian).

3. Slivka S.S. (2002) Filosofsko-pravovi problemy profesiinoi kultury yurysta [Philosophical and legal issues of professional culture of lawyers]. (PhD Thesis), Kharkiv: National Yaroslav the Wise Law Academy of Ukraine, $32 \mathrm{p}$.

4. Chuprinsky B.O. (2010) Formuvannia profesiinoi kultury maibutnih yurystiv: filosofsko-pravove doslidzhennia [Formation of professional culture of future lawyers: philosophical and legal research]. Extended abstract of candidate's thesis. Lviv: Lviv State University of Internal Affairs, 20 p. (in Ukrainian).

5. Burdonosova M.A. (2015) Metodolohichni osoblyvosti doslidzhennya profesiynoyi kultury yurystiv [Methodologocal features of reserch of professional culture of lawyers]. Public law, vol. 4(20)/2015, pp. 261-266. (in Ukrainian).

6. Yudin E.G. (1978) Sistemnyi podhod $i$ printsip deiatelnosti. Metodologicheskie problem sovremennoi nauki [Systematic approach and the principle of action. Methodological problems of modern science]. Moscow: Nauka, 378 p. (in Russian). 
7. Gusarev S.D., Tykhomyrov O.D. (2010) Yurydychna deontologiia (Osnovy yurydychnoi diialnosti) [Legal deontology (Principles of Law): teach. guidances.] (4th ed.). Kyiv: Znannia, 495 p. (in Ukrainian).

8. Kazimirchuk V.P. (1965) Pravo i metody ego izucheniia [Law and methods of its study [monograph]. Moscow: Yurydychna literatura, $204 \mathrm{p}$. (in Russian).

9. Chernetska O.V., Shilingov V.S. (2009) Yurydychna komparatyvistyka yak samostiyna yurydychna naukova dystsyplina [Legal comparative studies as an independent legal scientific discipline]. Ukrainian Greek International Scientific Law Journal "Comparative Legal Studies", 2009, vol. 1, pp. 23-28. (in Ukrainian).

10. Brudnyi A.A. (1977) $\mathrm{K}$ probleme modelirovaniya $\mathrm{v}$ sotsialnoy psikhologii [To the problem of modeling in social psychology]. Metodologiya $i$ metody sotsialnoy psikhologii. [Methodology and methods of social psychology]. Moscow: Nauka, pp. 86-95 (in Russian).

\section{Information about the author: \\ Maryna Burdonosova,}

$\mathrm{PhD}$ in Law,

Associate Professor at the Department of Constitutional and Administrative Law, Faculty of Law, Institute of Management and Technology, State University of Infrastructure and Technologies 2, Heroiv of Stalinhradu Ave, Kyiv, Ukraine ORCID ID: orcid.org/0000-0003-1050-6892 


\section{THE POLITICAL SYSTEM OF SOCIETY: FEATURES AND PROSPECTS OF DEVELOPMENT IN UKRAINE}

\section{Olha Chepik-Trehubenko}

\section{INTRODUCTION}

The social order of each country implies the existence of such a component as political system. At present, Ukrainian society is undergoing a stage of transformation of the political system, moving towards becoming an equal actor in the society-state relationship, thus developing the characteristic qualities of civil society. The multifunctionality of such a cognitive structure as the political system of society has caused the pluralism of opinions in the approaches to its interpretation, in particular from the point of law. The information component is key in the development of the political system of society.

Despite the significant contribution of such domestic and foreign scientists as O. Babkina, M. Baimuratov, E. Batalov, O. Batanov, P. Bieglov, Y. Bytiak, V. Bogatyriov, I. Butko, A. Vengerov, D. Vydrin, B. Gaievskyi, V. Helman, V. Horbatenko, V. Hrygoriev, O. Danylian, O. Dzioban, O. Demianchuk, M. Idrisova, D. Easton, V. Kampo, G. Klimova, M. Kononchuk, S. Korzh, V. Kostytskyi, S. Maksymov, M. Marchenko, L. Nalyvaiko, M. Orzikh, M. Panov, O. Petryshyn, V. Pohorilko, O. Proskurina, P. Rabinovych, O. Rudakevych, Y. Riaboi, P. Sas, H. Sashchuk, S. Seriohina, O. Skakun, V. Tatsii, Yu. Todyka, V. Trushyna, V. Khropaniuk, Y. Shemshuchenko, I. Shtuka, V. Yakoviuk, I. Yarulin and others, who have researched individual issues of the political system of society, there is a lack of a modern and effective scientific theoretical approach to understanding this category and features of the current state and further development, which negatively affects the formation of civil society and the rule of law in Ukraine.

The modernization of the political system of Ukrainian society in the modern era is one of the ambiguous phenomena, which results in the process of changing not only the political course of the state, but practically the whole substantive part of the political system of society. At the present stage, when Ukraine is getting rid of the remnants of the past and direct total interference in all spheres of society, it is important to analyze the nature and content of modernization of the political system of society, the features of its formation process and the prospects for its further development. For more than twenty years, Ukrainian society has been in a state of systemic transit - the transition to a new quality level of all spheres of its activity. 


\section{Concepts and features of the political system of society}

Every society, regardless of its level of development, is undergoing some degree of political and legal transformation. This is characteristic of both highly developed (civil) and the underdeveloped (tribal) society ${ }^{1}$. The problem of interaction between political existence and political consciousness has always interested scientists. But studies of the relationship between the ideal and the real in politics become relevant at the turning points of history, when the processes of democratization include broad sections of the population in socio-political life ${ }^{2}$. Since these issues need legal regulation, there is a need to study them from the standpoint of science of theory of state and law.

Today, the inability of political party leaders to consolidate and make important compromise decisions should be acknowledged as a negative phenomenon in the political system of society. The main transformational measures in the political system of society should be development of the Ukrainian political elite; harmonization of relations between all subjects of the political system of society; reform and adjustment of national legislation with international standards. The effectiveness of the political system ensures the proper functioning of the social, economic, spiritual and cultural spheres.

Each system of society is a single, orderly system of components, the interaction of which causes the emergence of a different quality. The political system is no exception. The term "political system of society" provides an opportunity to identify and characterize the political interests of different actors.

Confusion in legal terminology on the understanding of the term "political system of society" needs to turn to theoretical developments in this field.

The category "political system of society" has been introduced into the scientific field relatively recently, at the stage of development of society, when political parties, public associations, movements began to operate alongside state institutions. Exploring the issues of the political system of society, L. Nalyvaiko concludes that in a broad sense it is a set of interrelated and interdependent political institutions stipulated by the Constitution and laws of Ukraine, which exercise power in society, regulate political relations, political activity, ensure stability and order in accordance with the achieved level of political culture. The scientist also emphasises that understanding the political system of society as a set of state and non-state institutions fetishizes

\footnotetext{
${ }^{1}$ Mynjkovych-Slobodjanyk O.V. (2015) Pravova ta politychna kuljtura v umovakh politykopravovoji transformaciji suspiljstva [Legal and political culture in the conditions of political and legal transformation of society]. Chasopys Kyjivsjkogho universytetu prava, no. 4, p. 28.

${ }^{2}$ Ishmanova G.D. (2007) Struktura politicheskoy kul'tury i proyavlenie ee komponentov v sotsial'no-politicheskoy zhizni sovremennoy Rossii [The structure of political culture and the manifestation of its components in the socio-political life of modern Russia] (PhD Thesis). Ufa: Bashkirskiy gosudarstvennyy universitet, p. 46-47.
} 
the state as a subject of the political system, thus denying the priority role of the people. After all, the political system is usually called the political system of society, not the political system of the state $^{3}$. This approach is of great practical importance for understanding the political sphere of society and the importance of active public in it. In the rule of law, the primary tasks of the political system of society are to ensure public order, to create conditions for political stability, and to harmonize important interests for society.

The emergence of the term "political system" was conditioned by the isolation of a set of different political phenomena into a certain integrity against the background of the rest of society ${ }^{4}$. In legal science, domestic studies of the political system of Ukrainian society began in the $60 \mathrm{~s}$ of the $20^{\text {th }}$ century". In general, the term "political system" was hardly used in the scientific works of domestic scientists until the $70 \mathrm{~s}$ of the $20^{\text {th }}$ century. Instead, the term "political organization of society" was applied ${ }^{6}$. In Soviet times, the political system was regarded, as a rule, formally, symbolically, as a collection of political organizations ${ }^{7,8}$.

The political system does not exist separately from the external environment with which it interacts with aid, carrying out "transformation" within itself. This makes it possible to speak of the implementation of the political system and, accordingly, of its internal processes in some general plane 9 .

Today in the scientific literature, in particular the legal, political systems of society are offered to understand as follows: the political system is an integrated set of state and non-state social institutions that exercise power, manage the affairs of society, regulate the relationship between citizens, social groups, nations, states, states stability of society, a certain social $\operatorname{order}^{10}$;

\footnotetext{
${ }^{3}$ Nalyvajko L.R. (2009) Derzhavnyj lad Ukrajiny: teoretyko-pravova modelj [State system of Ukraine: theoretical and legal model]: monoghrafija. Kharkiv: Pravo, p. 38-40.

${ }^{4}$ Ghotun A. (2011) Osnovni koncepciji doslidzhennja komunikaciji v politychnij systemi suspiljstva [Basic concepts of communication research in the political system of society]. Politychnyj menedzhment, no. 1, p. 75.

5 Nedbajlo P.O. (1967) Politychna orghanizacija suspiljstva [Political organization of society]. Kyjiv: In-t derzhavy i prava AN Ukrajiny, Naukova dumka.

${ }^{6}$ Il'inskiy I.P. i dr. (1975) Politicheskaya organizatsiya i upravlenie obshchestvom pri sotsializme [Political organization and management of society under socialism]. Moskva: Mysl'

7 Butko I.P., Kornijenko M.I. (1988) Politychna systema radjansjkogho suspiljstva [The political system of Soviet society]. Kyjiv: Radjansjka shkola, p. 23.

${ }^{8}$ Nalyvajko L.R. (2009) Derzhavnyj lad Ukrajiny: teoretyko-pravova modelj [State system of Ukraine: theoretical and legal model]: monoghrafija. Kharkiv: Pravo, p. 38-40.

${ }^{9}$ Ghotun A. (2011) Osnovni koncepciji doslidzhennja komunikaciji v politychnij systemi suspiljstva [Basic concepts of communication research in the political system of society]. Politychnyj menedzhment, no. 1, p. 76.

${ }^{10}$ Keljman M.S., Murashyn O.Gh., Khoma N.M. (2003) Zaghaljna teorija derzhavy ta prava [General theory of state and law]: pidruchnyk. Ljviv: Novyj svit-2000, p. 145.
} 
component, organic part of the social system, which includes the totality of different social subjects and institutions, united by participation in the political life of society, the various forms of political relations and relationships in which it is realized and the core of which are relations about state power and the results of political activity ${ }^{11}$; set of political institutions and organizations, political activity, political relations, political norms, principles and traditions, political consciousness, culture and media in their interaction, reflecting the interests and will of the social associations that exercise political power, struggle for its exercise within rights through the state ${ }^{12}$; holistic, orderly set of political institutions, political roles, relations, processes, principles of political organization of society, subordinate to the code of political, social, legal, ideological, cultural norms, historical traditions and principles of political regime of a particular society ${ }^{13}$; holistic, orderly set of political institutions, political relations, processes, principles of political organization of a society, subject to certain political, social, legal, ideological, cultural norms, historical traditions and principles of political regime of a particular society $^{14}$; a comprehensively organized and orderly set of political institutions, which are intended to carry out their activities on the normative and legal basis and to promote the legitimacy of political power in the state, as well as to provide social and spiritual guarantees for the development of society ${ }^{15}$. The concept of a political system is multidimensional in nature, the content of which are organizational and political institutions.

In its system, the phenomenon under study includes the organization of political power, relations between society and public authority.

Successful development of Ukraine as a European democratic state is impossible without realizing the importance of introducing effective ways of modernizing the political system of society.

${ }^{11}$ Ghoncharov P.K. (2009) Polytycheskaja systema rossyjskogho obshhestva v uslovyjakh postsovetskogho tranzyta: socyologhycheskyj analyz [The Political System of Russian Society in Post-Soviet Transit Conditions: A Sociological Analysis] (PhD Thesis). Moskva: Ros. akad. ghos. Sluzhby, p. 19-20.

${ }^{12}$ Volynyka K.Gh. (2003) Teorija derzhavy i prava [The theory of state and law]: navch. posib. Kyjiv: MAUP, p. 23.

13 Aznagulova G.M. (2010) O vzaimodeystvii pravovoy i politicheskoy system [On the interaction of legal and political systems]. Yurisprudentsiya, T. 20, vol. 4, p. 6.

14 Jusov A.V. (2008) Politychna systema suchasnogho suspiljstva: ponjattja, struktura, funkciji [The political system of modern society: concepts, structure, functions]. Derzhava $i$ pravo. Jurydychni i politychni nauky, vol. 41, p. 113.

${ }^{15}$ Nazarenko O. (2012) Politychna systema suspiljstva: sutnistj, osnovni rysy, funkciji [Political system of society: essence, main features, functions]. Visnyk Kyjivsjkogho nacionaljnogho universytetu imeni Tarasa Shevchenka. Jurydychni nauky, vol. 94, p. 87. 
Based on this analysis, it is appropriate to define the term "political system of society" as a coherent and complex set of elements, the tasks of which are aimed at achieving and ensuring the stable functioning of society through their effective interaction and implementation of political functions in accordance with the fundamental principles of law.

Among the features of the political system of society are the following: the integrity and complexity of the elements; conditional independence; internal and external relationships; static and dynamic character; normative regulation.

\section{Institutions of the political system of society and their characteristics}

Political parties that really represent society are an indispensable element of representative democracy ${ }^{16}$. One of the basic principles of such parties is openness to dialogue with the public and with other political parties in the country.

In modern democratic states, the political systems of society seek to balance in every possible way, taking into account the interests and needs of all subjects.

As of January 1, 2019, 352 political parties have been registered in Ukraine in accordance with the procedure established by law ${ }^{17}$. At the same time, the overwhelming majority of parties do not engage in active political activity; new parties are mostly registered for further "commercial use" 18 .

An integral part of the political system of any democratic society is the functioning of the opposition and the basis for the development of civil society. In the system of political relations, the opposition performs significant positive functions: it promotes the separation, reflection and generalization of the interests of population groups that are not satisfied with the activities of different branches of government in the centre and regions ${ }^{19}$. However, it is not necessary to exaggerate the positive role of the opposition, since individual opposition groups used democratic norms and procedures as a means of protecting the narrowminded interests and ambitious claims of their leaders for national representation $^{20}$. The effectiveness of political opposition is determined by a

${ }^{16}$ Grin'ko V.V. (2006) Sotsial'no-politicheskaya sistema obshchestva kak elektoral'naya model' [Socio-political system of society as an electoral model]. Sotsiologiya vlasti, no. 3, p. 150.

${ }^{17}$ Vidomosti z sajtu Ministerstva justyciji Ukrajiny [Information from the website of the Ministry of Justice of Ukraine] https://minjust.gov.ua/m/4561

${ }^{18}$ Jakymenko Yu., Bychenko A., Zamjatin V. ta in. Ukrajina 2016-2017: oznaky proghresu ta symptomy rozcharuvannja (analitychni ocinky) [Ukraine 2016-2017: signs of progress and symptoms of disappointment (analytical estimates)]. Kyjiv.

${ }_{19}$ Morarj M.V. (2017) Politychna opozycija jak nevid'jemnyj element politychnoji systemy suspiljstva [Political opposition as an integral part of the political system of society]. Ghileja, vol. 118.

${ }^{20}$ Mykhaljchenko M., Kuras I., Rudych F. ta in. (2002) Vzajemodija politychnoji vlady i opozyciji jak politologhichna problema [The interaction of political power and opposition as a political problem]. Suchasna ukrajinsjka polityka i politologhija pro neji. Kyjiv: In-t derzhavy i prava im. V.M. Korecjkogho, p. 26. 
number of factors, in particular: normative and legal regulation, public support for the opposition, and constructiveness of opposition forces.

Accordingly, the processes taking place in the political system have a significant impact on the results of transformations throughout society. The maintenance of Ukraine as an independent state depends on the content of its activity, quality of functioning, coherence of actions of all its subsystems.

Special communication tools are required to maintain a constant connection between policy makers. This is conditioned by the very nature of politics as a collective, complexly organized purposeful activity, a specialized form of communication of people for the realization of group goals and interests that interest the whole society. The collective nature of the goals that are pursued in politics implies a compulsory awareness of the divisions within the collective (states, nations, parties, etc.) and the coordination of activities of people and organizations. All this, of course, is impossible with the direct, contact interaction of citizens and requires the use of special means of information transmission, which ensure the unity of will and focus of actions of a large number of distant people ${ }^{21}$. An effective communication channel between the subjects of the political system and other entities requires permanent improvement of information and communication technologies, since the current state of information and technological support in Ukraine does not correspond to international and advanced achievements in this field.

Among the novelties of domestic legislation in the political sphere of society, the rule on state financing of the statutory activities of political parties deserves special attention. According to the approved changes, the statutory activities of political parties, not related to their participation in the elections of the People's Deputies of Ukraine, elections of the President of Ukraine and local elections, are financed at the expense of the State Budget of Ukraine, as well as the expenses of political parties related to the financing of their election campaigning during the next and early elections of the People's Deputies of Ukraine are reimbursed. The annual amount of state funding for the statutory activities of political parties is set: two hundredths of the minimum wage set for January 1 . It is determined that the right to receive state funding for statutory activity is held by a party whose election list received at least $2 \%$ of the valid votes of voters who took part in the last regular or early elections of the People's Deputies of Ukraine in the national constituency ${ }^{22}$. However, on October 2, 2019, the Verkhovna Rada of Ukraine

${ }^{21}$ Ghotun A. (2011) Osnovni koncepciji doslidzhennja komunikaciji v politychnij systemi suspiljstva [Basic concepts of communication research in the political system of society]. Politychnyj menedzhment, no. 1, p. 78.

${ }_{22}$ Chernoivanenko A.V. (2016) Funkcionuvannja politychnykh partij v Ukrajini: osoblyvosti normatyvno-pravovogho zabezpechennja [Functioning of political parties in Ukraine: features of normative legal support]. Teorija ta praktyka derzhavnogho upravlinnja, vol. 3, p. 70-71. 
cancelled funding for parties that did not overcome the 5\% barrier in elections.

The main task of the law is to reduce the risks of political corruption by introducing comprehensive amendments to the legislation of Ukraine in the field of financing political parties and election campaigning, in particular: reducing the dependence of parties on financing by private donors (oligarchs, industrial-financial groups, and so on); creating conditions for free and fair inter-party competition and the development of new parties through the introduction of state funding for parties; enhancing the transparency of funding for political parties and their local organizations, as well as enhancing the transparency of election campaign funding; imposition of effective, proportionate and efficient sanctions for violations in party financing and election campaigning ${ }^{23}$.

Expert opinions on financing political parties in Ukraine should be provided. V. Taran, in particular, believes that this law will take time to implement it if the parties are more virtuous and not tied to the money received from certain patrons. The expert also emphasised on foreign practice: in Lithuania and Estonia similar changes worked immediately, while in Latvia and Poland there are still problems ${ }^{24}$. The system of state funding of parties is very simple - it assesses the effectiveness of parties by election results and, according to these results, political forces are compensated for their activities. In our country, the financing of political parties needs to be brought to a completely new transparent system. This should be a system of membership contributions, one-off contributions from party members in the election year, etc. Political parties should be financed exclusively from transparent, taxconfirmed funds, according to V. Tsybulko ${ }^{25}$. However, it is important to develop appropriate mechanisms for the legal accountability of political parties for violating the relevant rules of the law.

Moreover, it should be noted that this issue needs further thorough study due to the lack of trust of the citizens of Ukraine in the activities of political parties. As of March 2019, after a sociological survey, 76\% of citizens expressed their distrust.

${ }^{23}$ Zakon pro finansuvannja politychnykh partij iz derzhavnogho bjudzhetu [Law "On financing political parties from the state budget”] https:/uk.wikipedia.org/wiki/ Закон_про_фінансування_політичних_партій_із_державного_бюджету

${ }^{24}$ Chernoivanenko A.V. (2016) Funkcionuvannja politychnykh partij v Ukrajini: osoblyvosti normatyvno-pravovogho zabezpechennja [Functioning of political parties in Ukraine: features of normative legal support]. Teorija ta praktyka derzhavnogho upravlinnja, vol. 3, p. 70.

${ }^{25}$ Derzhavne finansuvannja partij: pljusy ta ryzyky [Public party funding: benefits and risks] https://antikor.com.ua/articles/59246-derhavne_finansuvannja_partij_pljusi_ta_riziki 
Thus, in March 2019, 1.4\% of citizens fully trusted parties, $10.1 \%$ - rather trusted $^{26}$. So, in general, the public is very negative about most parties. The early parliamentary elections in July 2019 had a significant impact on the Ukrainian political party and became unprecedented, with the first opportunity to form a coalition of members of one party (including majority members who are members of the respective party) - a total of $43,16 \%$ of votes.

Despite the recent developments, the political system of society in the sphere of political parties' activity needs significant modernization.

An important area for domestic parties is international cooperation. In particular, the implementation of Ukraine's European integration course requires consolidation of efforts by diplomats and non-governmental policy makers in promoting the country's interests in the European community. Inter-party cooperation has a significant potential in shaping the image of the state favourable for European integration and achieving political support for the country's position in the EU. Promising in this context is the development of links with European transnational parties, which are becoming increasingly influential in Europe $^{27}$.

Sufficient social experience of the developed democracies is convincing evidence that the current political system, in its present form, could not have developed without the influence of the institution of local self-government. The question of the existence and development of the system of local selfgovernment is a dialectical transformation of the whole system of power relations in the country, and its local economic, political and other local and autonomous activity serves as a powerful source of change in these spheres. Under this approach, local self-government should be characterized as a power. But it is a power of a special kind, the power of the people, which has all the necessary capabilities for self-organization in the local territory, without the pressure of strict standards, capable of realizing its control function $^{28}$. In the modern democratic, social-legal state the necessity of formation and development of local self-government is caused by a number of reasons. One of them is the growing importance and strengthening of the role

${ }^{26}$ Rivenj doviry do suspiljnykh instytutiv ta elektoraljni orijentaciji ghromadjan Ukrajiny [The level of trust in public institutions and the electoral orientation of Ukrainian citizens] http://razumkov.org.ua/napriamky/sotsiologichni-doslidzhennia/riven-doviry-do-suspilnykhinstytutiv-ta-elektoralni-oriientatsii-gromadian-ukrainy-2

27 Partijno-ideologhichna strukturyzacija jevropejsjkogho politychnogho prostoru ta mozhlyvosti prosuvannja interesiv Ukrajiny v JeS [Party-ideological structuring of the European political space and opportunities for promoting Ukraine's interests in the EU] http://www.niss.gov.ua/articles/693/

${ }_{28}^{28}$ Trebin M. p. ta in. (2013) Ghromadjansjke suspiljstvo: politychni ta socialjno-pravovi problemy rozvytku [Civil society: political and socio-legal problems of development]: monoghrafija. Xarkiv: Pravo, p. 218. 
of territorial communities. Under the conditions of a political system of a democratic society, the territorial communities, which are the basis and the primary subject of local self-government, play an undeniable role, since they ensure its normal and effective functioning.

The importance of the development of the scientific problems of the place of the territorial community in the political system of society in the present transformational conditions requires comprehensive research. This is due to their mobile nature, dependence of development and essence on changes in state and public life, on political, economic, social and other transformations.

It is the awareness of the importance of the territorial community in the political system of society that significantly updates the search for researchers in this field.

Territorial communities are one of the important institutions of the political system. The concept of territorial community is relatively new to the legal science of Ukraine. Despite the lack of consensus among scientists on the definition of "territorial community", it has received its legislative definition, including in the Constitution of Ukraine. This once again confirmed the importance of this institute. According to the provisions of the Basic Law of the state and the law of Ukraine "On local self-government in Ukraine", a territorial community is residents united by permanent residence within a village, settlement, city, which are independent administrativeterritorial units, or voluntary union of residents of several villages having a single administrative centre. Also, the legislation of Ukraine, in particular in the mentioned legal acts, enshrines a rather wide range of powers of the territorial community in public administration, namely elections of deputies of local councils, village, town and city mayors, local referendums, general meetings (conferences), public hearings initiatives, management of communal property, approval of the programme of socio-economic and cultural development and control of their implementation, etc.

Territorial community in modern conditions acts as a form of social organization of society, a kind of social institution that provides implementation in a certain area of integration policy on the common interests of local residents ${ }^{29}$. An active, influential and advanced civil society is an essential element of any democratic state and plays one of the key roles in implementing urgent social change and good governance, managing public affairs and addressing local issues, developing and implementing effective public policies, asserting the rule of law responsible to the person, solving

${ }^{29}$ Baranovsjka T.M. (2017) Derzhavna polityka rozvytku terytorialjnykh ghromad v Ukrajini [State Policy for Development of Territorial Communities in Ukraine] (PhD Thesis). Kharkiv: Nacionaljna akademija derzhavnogho upravlinnja pry Prezydentovi Ukrajiny, p. 6. 
political, socio-economic and humanitarian problems. The empowerment of the local community in the exercise of local self-government is defined as an important direction in the implementation of the National Strategy for Promoting Civil Society Development in Ukraine for 2016-2020 $0^{30}$. In spite of the thorough regulatory support of the rights of the territorial community, there are still some gaps in their legislative regulation and a number of problems in the mechanism of their implementation.

Since becoming an independent state, Ukraine has developed a system of local self-government, but in its essence it has many Soviet features, which hinders the democratic development of society and the state. Therefore, the current direction of institutional changes in the political system of Ukrainian society is the reform of public authorities at the regional and local levels.

Without a doubt, reforming the system of local self-government to a state that would maximize the interests of citizens in all spheres of life is of utmost importance. According to the majority of experts and practitioners, the main task of reforming the system of organization of power at the local level is the formation of a proper resource base for the realization of the right to local self-government by territorial communities ${ }^{31}$.

The implementation of a series of effective measures will help to establish in Ukraine a democratic model of the political system of the European model, which will allow to ensure in practice the principles of the rule of law, the possibility of real implementation of the constitutional rights of territorial communities, their proper management, the effective functioning of local self-government.

The legal institutionalization of a territorial community is conditioned by the growing role of the territorial community and the need to strengthen legal statehood. The territorial community is an important component of the political system of society and plays a decisive role in the democratization of Ukraine's state system. Further scientific elaborations of this problem are necessary for the prospect of development of local self-government, extension of rights of territorial communities and improvement of the mechanism of their realization, in the conditions of formation of the rule of law and civil society.

${ }^{30}$ Nacionaljna strateghija spryjannja rozvytku ghromadjansjkogho suspiljstva v Ukrajini na 2016-2020 roky [National Strategy for Promoting Civil Society Development in Ukraine for 2016-2020]:Ukaz Prezydenta Ukrajiny vid 26 ljutogho 2016 r. Oficijnyj visnyk Prezydenta Ukrajiny, 2016, no. 7

${ }^{31}$ Pro vnutrishnje ta zovnishnje stanovyshhe Ukrajiny v 2013 roci [On the internal and external situation of Ukraine in 2013]: Shhorichne Poslannja Prezydenta Ukrajiny do Verkhovnoji Rady Ukrajiny. Kyjiv : NISD, 2012, p. 200. 


\section{Political culture as an element of the political system of society}

Political culture is a fundamental component of the political system of society. Political values are dominant in political culture. Political values include: equality, justice, democracy, freedom, socialism, security, state, statism, paternalism, monarchy, peace, etc. Political values are socio-political ideals (freedom, justice, equality, etc.) and political phenomena reflected in consciousness (state, monarchy, statism, etc.). For each subject of political life, the range of significant political phenomena will be different. Therefore, it can be said that political values are the value orientations in the sphere of politics of a particular subject of political life and the objects of these orientations. On the other hand, values that are inherent only in the political culture of these societies are formed in the political culture of different societies. They reflect the general aspirations of the people. Formed under the influence of various factors, including under the influence of the national culture of society, these values are embodied in the minds of the people, determine the general order of their opinions regarding political power, political system, future of the country, define political culture as such. Therefore, more precisely, political values can be defined as extremely general orientations and ideals of society in the socio-political sphere, as well as politically significant social phenomena that are fixed in the mind of people and represent a characteristic feature of general life activity ${ }^{32,33}$.

However, the urgency of the problem now lies in the fact that in Ukraine there has not yet emerged a full-fledged political nation with clearly defined national interests, for which a consensus would emerge both among the elite and among citizens. In these circumstances, the process of Ukrainian state formation is difficult and ambiguous ${ }^{34}$. Thus, in today's reality, in the context of active integration of politics into people's lives, it is urgent and necessary to determine the proper place and role of political culture, since the latter has a fundamental influence on the formation of citizenship and, accordingly, the formation of a democratic state.

However, despite the diversity of political parties and public associations, new associations and parties are emerging in the current political system. The

${ }^{32}$ Djomina O.S. (2014) Politychna kuljtura jak cinnisno-normatyvna systema suchasnogho ukrajinsjkogho suspiljstva [Political culture as a value-normative system of modern Ukrainian society]. Naukovyj chasopys NPU imeni M. P. Draghomanova, vol. 15, p. 149.

${ }^{33}$ Korzh S.A. (2009) Fraghmentarna politychna kuljtura jak vyjav perekhidnogho periodu rozvytku ukrajinsjkogho suspiljstva [Fragmentary political culture as a manifestation of the transitional period of development of Ukrainian society] (PhD Thesis). Kyjiv: Nac ped. un-t im. M. P. Draghomanova, p. 8.

${ }^{34}$ Karlova V.V. (2013) Nacionaljna samosvidomistj jak dukhovna osnova derzhavotvorchykh procesiv v Ukrajini: upravlinsjkyj aspekt [National consciousness as the spiritual basis of statemaking processes in Ukraine: the administrative aspect] (PhD Thesis). Kyjiv 
emergence of new political parties and public associations indicates the development of civil society and civic initiatives ${ }^{35}$.

The defining concept of political culture was proposed and introduced for the first time by American political scientist G. Almond, who in connection with an attempt to develop a classification for comparing political systems, noted that each political system was included in a specific model of policy orientation. This, according to the scientist, is appropriate to call political culture $^{36}$. Today, the term "political culture" can rightly be called one of the most common and, at the same time, one of the most controversial concepts in science.

From the moment of the emergence of political relations, that is, the institutionalization and alienation of the majority of members of one or another community of management relations, political culture emerges as a specification of the general culture ${ }^{37}$. Political culture is an integral part not only of politics but also of human existence. In the course of historical development, the interaction of culture and politics manifests itself as a dialectic of political, social, cultural processes, and manifests itself differently, depending on the specific efforts of the functioning of a society ${ }^{38}$. Culture is manifested and embodied in political and legal ideas, values, attitudes and institutions, power relations ${ }^{39}$. Political culture is a kind of translation of political experience and reproduction of political life of society, which makes it possible to consider it as the most important characteristic of the political system, which is going through a difficult stage of its development - the stage of democratic transition ${ }^{40}$. Contemporary political culture acts as a means of reproducing the political life of the society, a system of worldviews, orientations, patterns of behaviour of individuals and groups, as well as forms of functioning of political institutions that are manifested in the direct activity

35 Zimina N.V. (2014) Analiz politicheskikh partiy i obshchestvennykh ob'edineniy v partiynykh sistemakh [Analysis of political parties and public associations in party systems]. Vlast', no. 12, p. 63.

${ }^{36}$ Almond G.A. (1956) Comparative Political System. Journal of Politics, no. 18, p. 396.

${ }^{37}$ Duka A.V. (1995) Politicheskaya kul'tura: problemy genezisa i printsipy tipologii [Political culture: problems of genesis and principles of typology] ( $\mathrm{PhD}$ Thesis). Sankt-Peterburg, p. 4.

38 Ovsyannikov Yu.A. (2005) Politicheskaya kul'tura: sotsiokul'turnye osnovy vzaimodeystviya politiki i vlasti [Political culture: socio-cultural foundations of the interaction between politics and power] (PhD Thesis). Rostov-na-Donu: Rostovskiy gosudarstvennyy universitet, p. 6.

${ }^{39}$ Gurevich A.Ya. (1984) Kategorii srednevekovoy kul'tury [Medieval Culture Categories]. Moskva: Iskusstvo, p. 26.

${ }^{40}$ Ishmanova G.D. (2007) Struktura politicheskoy kul'tury i proyavlenie ee komponentov v sotsial'no-politicheskoy zhizni sovremennoy Rossii [The structure of political culture and the manifestation of its components in the socio-political life of modern Russia] (PhD Thesis). Ufa: Bashkirskiy gosudarstvennyy universitet, p. 3 . 
of the subjects of the political process. Political culture has a systemic character at the national level, because it is part of a complex adaptation mechanism of a particular people to the conditions of their own life ${ }^{41}$. The public's positive or negative attitude to decisions made by public authorities depends, among other things, on the level of political culture.

Political culture as part of human culture can change under the influence of changes in the system of values of the culture of society. But the basic values (value bases) change rather slowly, they are little prone to changes, while peripheral values can undergo more frequent changes, be transformed in times of crisis of society, changes of political regimes. Political culture is a fairly conservative element of society's culture. Once formed, political culture remains a stable, integral formation at its core ${ }^{42}$.

Nowadays, politics is becoming increasingly active in the practical life of citizens. Therefore, it is especially important to take into account the place of political culture in public life, its influence on the civic position of the population, etc. Political culture is understood as a qualitative composition of the political life of a society, determined by historical, socio-economic and political conditions and reflects the awareness of the subject - society, group of persons, person - relevant political relations, ways of activity, norms and values, the degree of socio-cultural development of man and the degree of their activity in the transformation of political and social reality ${ }^{43}$. The political culture of civil society must be developed as one of the main conditions for socio-political stability. Involving citizens in the decisionmaking process will help to shape a democratic political culture in Ukraine. In turn, citizens should also understand that the position of removal from politics, which is often observed today in the formation of public authorities, is far from being better on condition that the authorities try to secure a space of self-control and permissiveness.

Analyzing the influence of political culture on the transformation processes of Ukrainian society, Yu. Riaboy concludes that political culture is a set of political values, norms, orientations and ways of behaviour of citizens in relation to politics in general, the political system, as well as their role in

${ }^{41}$ Trebin M. p. ta in. (2013) Ghromadjansjke suspiljstvo: politychni ta socialjno-pravovi problemy rozvytku [Civil society: political and socio-legal problems of development]: monoghrafija. Xarkiv: Pravo, p. 318.

${ }^{42}$ Djomina O.S. (2014) Politychna kuljtura jak cinnisno-normatyvna systema suchasnogho ukrajinsjkogho suspiljstva [Political culture as a value-normative system of modern Ukrainian society]. Naukovyj chasopys NPU imeni M. p. Draghomanova, vol. 15, pp. 150.

${ }^{43}$ Korzh S.A. (2009) Fraghmentarna politychna kuljtura jak vyjav perekhidnogho periodu rozvytku ukrajinsjkogho suspiljstva [Fragmentary political culture as a manifestation of the transitional period of development of Ukrainian society] (PhD Thesis). Kyjiv: Nac ped. un-t im. M.P. Draghomanova, p. 7. 
this system. The scientist also points out that increasing the level of political culture seems to be possible by increasing the openness of the political system, as well as by acquiring it with the ability to react in a timely manner to socio-political transformations; raising ideological and organizational pluralism; creating effective and efficient mechanisms for preventing the violation of citizens' rights; formation of a new adequate time and democratic norms of the political elite; closing the gap between citizens and political power; providing opportunities for real participation of the population in political processes, etc. ${ }^{44}$

Thus, political culture is a multifaceted phenomenon with its historical, social, political, legal and psychological roots. In addition to the fact that political culture is considered one of the indispensable components of the institutions of society, it influences all spheres of both state and public life, it is a system of values that shape the identity of nations, the unity of the state. An analysis of the current state of political culture allows us to find answers to a number of questions that are important for an objective assessment of the progress of reforms, clarification of the strategy and tactics of our country's development.

\section{CONCLUSIONS}

Based on a comprehensive theoretical and legal analysis of the political system of society, we can state the following.

1. The political system of society is a coherent and complex set of elements, the task of which is aimed at achieving and ensuring the stable functioning of society through their effective interaction and exercise of political functions in accordance with the fundamental principles of law. Features of the political system of society are: the integrity and complexity of the elements; conditional independence; internal and external relationships; static and dynamic character; normative regulation. The following is defined: 1) in Ukraine, civil society institutions do not act as full (real) subjects of political and public activity; 2) the national model of political culture as a component of the political system of society has not been formed in society. This causes the social order of Ukraine to be frozen; active participation of the public in the management of public and state affairs will produce renewal and modernization of the political system, emergence of new public and political leaders, formation of citizens' trust in the authorities, strengthening of democracy. Political opposition is a necessary element and factor in the development of an open society, a democratic and rule of law.

44 Rjaboj Yu.O. (2012) Vplyv politychnoji kuljtury na transformacijni procesy ukrajinsjkogho suspiljstva [The influence of political culture on the transformation processes of Ukrainian society] (PhD Thesis). Mykolajiv: Chornomor. derzh. un-t im. Petra Moghyly, p. 5-6. 
2. It is important to develop inter-party cooperation at: 1) internal (between domestic parties) level and 2) external (implies two strategic directions: European parties and parties of other democratic states of the world). The current political system of Ukrainian society is open and requires communication of its subjects with international partners. In today's democratic, social-legal state, the need for the establishment and development of local self-government is due to a number of reasons. Under the conditions of a political system of a democratic society, the territorial communities, which are the basis and the primary subject of local self-government, play an undeniable role, since they ensure its normal and effective functioning.

3. Political culture is the deterministic historical, political, social, psychological, legal influence of the views, values and ideals of a society, group of persons or persons, expressed in the attitude of these subjects to the political process in the country of residence. Political culture must be developed as one of the main conditions for socio-political stability. Involving citizens in the decision-making process will help to shape a democratic political culture in Ukraine. In turn, citizens should also be aware that the position of removal from politics, which is often followed today in the formation of state bodies, is far from being better when the authorities try to secure a space of self-control and permissiveness.

\section{SUMMARY}

The paper deals with the problems of functioning of the political system of society in Ukraine from the standpoint of theoretical and legal science. It is emphasised that the political system of society is a coherent and complex set of elements, the task of which is aimed at achieving and ensuring the stable functioning of society through their effective interaction and implementation of political functions in accordance with the fundamental principles of law. The features of the political system have been identified. It is stressed that in Ukraine civil society institutions do not act as full (real) subjects of political and public activity. It is also noted that the national model of political culture as a component of the political system of society has not been formed in society. It is emphasised that the modern political system of Ukrainian society is open and requires communication of its subjects with international partners. The role of the territorial community in the development of Ukraine's political system is revealed. The definition of political culture is proposed. Political culture must be developed as one of the main conditions for socio-political stability. 


\section{REFERENCES}

1. Mynjkovych-Slobodjanyk O.V. (2015) Pravova ta politychna kuljtura $\mathrm{v}$ umovakh polityko-pravovoji transformaciji suspiljstva [Legal and political culture in the conditions of political and legal transformation of society]. Chasopys Kyjivsjkogho universytetu prava, no. 4, pp. 28-31 [in Ukrainian].

2. Ishmanova G.D. (2007) Struktura politicheskoy kul'tury i proyavlenie ee komponentov v sotsial'no-politicheskoy zhizni sovremennoy Rossii [The structure of political culture and the manifestation of its components in the socio-political life of modern Russia] ( $\mathrm{PhD}$ Thesis). Ufa: Bashkirskiy gosudarstvennyy universitet [in Russian].

3. Nalyvajko L.R. (2009) Derzhavnyj lad Ukrajiny: teoretyko-pravova modelj [State system of Ukraine: theoretical and legal model]: monoghrafija. Kharkiv: Pravo [in Ukrainian].

4. Ghotun A. (2011) Osnovni koncepciji doslidzhennja komunikaciji v politychnij systemi suspiljstva [Basic concepts of communication research in the political system of society]. Politychnyj menedzhment, no. 1, pp. 75-86 [in Ukrainian].

5. Nedbajlo P.O. (1967) Politychna orghanizacija suspiljstva [Political organization of society]. Kyjiv: In-t derzhavy i prava AN Ukrajiny, Naukova dumka [in Ukrainian].

6. Il'inskiy I.P. i dr. (1975) Politicheskaya organizatsiya i upravlenie obshchestvom pri sotsializme [Political organization and management of society under socialism]. Moskva: Mysl' [in Russian].

7. Butko I.P., Kornijenko M.I. (1988) Politychna systema radjansjkogho suspiljstva [The political system of Soviet society]. Kyjiv: Radjansjka shkola [in Ukrainian].

8. Keljman M.S., Murashyn O. Gh., Khoma N.M. (2003) Zaghaljna teorija derzhavy ta prava [General theory of state and law]: pidruchnyk. Ljviv: Novyj svit-2000 [in Ukrainian].

9. Ghoncharov P. K. (2009) Polytycheskaja systema rossyjskogho obshhestva v uslovyjakh postsovetskogho tranzyta: socyologhycheskyj analyz [The Political System of Russian Society in Post-Soviet Transit Conditions: A Sociological Analysis] (PhD Thesis). Moskva: Ros. akad. ghos. Sluzhbы [in Russian].

10. Volynyka K.Gh. (2003) Teorija derzhavy i prava [The theory of state and law]: navch. posib. Kyjiv: MAUP [in Ukrainian].

11. Aznagulova G.M. (2010) O vzaimodeystvii pravovoy i politicheskoy system [On the interaction of legal and political systems]. Yurisprudentsiya, T. 20, vol. 4, pp. 5-15 [in Russian].

12. Jusov A.V. (2008) Politychna systema suchasnogho suspiljstva: ponjattja, struktura, funkciji [The political system of modern society: 
concepts, structure, functions]. Derzhava $i$ pravo. Jurydychni $i$ politychni nauky, vol. 41, pp. 112-116 [in Ukrainian].

13. Nazarenko O. (2012) Politychna systema suspiljstva: sutnistj, osnovni rysy, funkciji [Political system of society: essence, main features, functions]. Visnyk Kyjivsjkogho nacionaljnogho universytetu imeni Tarasa Shevchenka. Jurydychni nauky, vol. 94, pp. 86-90 [in Ukrainian].

14. Grin'ko V.V. (2006) Sotsial'no-politicheskaya sistema obshchestva kak elektoral'naya model' [Socio-political system of society as an electoral model]. Sotsiologiya vlasti, no. 3, pp. 149-157 [in Russian].

15. Vidomosti z sajtu Ministerstva justyciji Ukrajiny [Information from the website of the Ministry of Justice of Ukraine] https://minjust.gov.ua/m/4561 [in Ukrainian]

16. Jakymenko Ju., Bychenko A., Zamjatin V. ta in. Ukrajina 2016-2017: oznaky proghresu ta symptomy rozcharuvannja (analitychni ocinky) [Ukraine 2016-2017: signs of progress and symptoms of disappointment (analytical estimates)]. Kyjiv [in Ukrainian].

17. Morarj M.V. (2017) Politychna opozycija jak nevid'jemnyj element politychnoji systemy suspiljstva [Political opposition as an integral part of the political system of society]. Ghileja, vol. 118, pp. 323-326 [in Ukrainian].

18. Mykhaljchenko M., Kuras I., Rudych F.ta in. (2002) Vzajemodija politychnoji vlady i opozyciji jak politologhichna problema [The interaction of political power and opposition as a political problem]. Suchasna ukrajinsjka polityka i politologhija pro neji. Kyjiv: In-t derzhavy i prava im. V.M. Korecjkogho, pp. 20-33 [in Ukrainian].

19. Chernoivanenko A. V. (2016) Funkcionuvannja politychnykh partij v Ukrajini: osoblyvosti normatyvno-pravovogho zabezpechennja [Functioning of political parties in Ukraine: features of normative legal support]. Teorija ta praktyka derzhavnogho upravlinnja, vol. 3, pp. 67-74 [in Ukrainian].

20. Zakon pro finansuvannja politychnykh partij iz derzhavnogho bjudzhetu [Law "On financing political parties from the state budget"] https://uk.wikipedia.org/wiki/Закон_про_фінансування_політичних_партій_ із_державного_бюджету [in Ukrainian]

21. Derzhavne finansuvannja partij: pljusy ta ryzyky [Public party funding: benefits and risks] https://antikor.com.ua/articles/59246-derhavne_ finansuvannja_partij_pljusi_ta_riziki [in Ukrainian]

22. Rivenj doviry do suspiljnykh instytutiv ta elektoraljni orijentaciji ghromadjan Ukrajiny [The level of trust in public institutions and the electoral orientation of Ukrainian citizens] http://razumkov.org.ua/napriamky/ sotsiologichni-doslidzhennia/riven-doviry-do-suspilnykh-instytutiv-ta-elektoralnioriientatsii-gromadian-ukrainy-2 [in Ukrainian] 
23. Partijno-ideologhichna strukturyzacija jevropejsjkogho politychnogho prostoru ta mozhlyvosti prosuvannja interesiv Ukrajiny $\mathrm{v}$ JeS [Partyideological structuring of the European political space and opportunities for promoting Ukraine's interests in the EU] http://www.niss.gov.ua/articles/693/ [in Ukrainian]

24. Trebin M.P. ta in. (2013) Ghromadjansjke suspiljstvo: politychni ta socialjno-pravovi problemy rozvytku [Civil society: political and socio-legal problems of development]: monoghrafija. Xarkiv: Pravo [in Ukrainian].

25. Baranovsjka T.M. (2017) Derzhavna polityka rozvytku terytorialjnykh ghromad v Ukrajini [State Policy for Development of Territorial Communities in Ukraine] (PhD Thesis). Kharkiv: Nacionaljna akademija derzhavnogho upravlinnja pry Prezydentovi Ukrajiny [in Ukrainian].

26. Nacionaljna strateghija spryjannja rozvytku ghromadjansjkogho suspiljstva v Ukrajini na 2016-2020 roky [National Strategy for Promoting Civil Society Development in Ukraine for 2016-2020]:Ukaz Prezydenta Ukrajiny vid 26 ljutogho 2016 r. Oficijnyj visnyk Prezydenta Ukrajiny, 2016, no. 7 [in Ukrainian].

27. Pro vnutrishnje ta zovnishnje stanovyshhe Ukrajiny v 2013 roci [On the internal and external situation of Ukraine in 2013]: Shhorichne Poslannja Prezydenta Ukrajiny do Verkhovnoji Rady Ukrajiny. Kyjiv : NISD, 2012 [in Ukrainian].

28. Djomina O.S. (2014) Politychna kuljtura jak cinnisno-normatyvna systema suchasnogho ukrajinsjkogho suspiljstva [Political culture as a valuenormative system of modern Ukrainian society]. Naukovyj chasopys NPU imeni M.P. Draghomanova, vol. 15, pp. 148-155 [in Ukrainian].

29. Karlova V.V. (2013) Nacionaljna samosvidomistj jak dukhovna osnova derzhavotvorchykh procesiv $v$ Ukrajini: upravlinsjkyj aspekt [National consciousness as the spiritual basis of state-making processes in Ukraine: the administrative aspect] (PhD Thesis). Kyjiv [in Ukrainian].

30.Zimina N.V. (2014) Analiz politicheskikh partiy i obshchestvennykh ob"edineniy v partiynykh sistemakh [Analysis of political parties and public associations in party systems]. Vlast', no. 12, pp. 62-64 [in Russian].

31. Almond G.A. (1956) Comparative Political System. Journal of Politics, no. 18, p. 394-409.

32. Duka A.V. (1995) Politicheskaya kul'tura: problemy genezisa i printsipy tipologii [Political culture: problems of genesis and principles of typology] (PhD Thesis). Sankt-Peterburg [in Russian].

33. Ovsyannikov Yu.A. (2005) Politicheskaya kul'tura: sotsiokul'turnye osnovy vzaimodeystviya politiki i vlasti [Political culture: socio-cultural foundations of the interaction between politics and power] ( $\mathrm{PhD}$ Thesis). Rostov-na-Donu: Rostovskiy gosudarstvennyy universitet [in Russian]. 
34. Gurevich A. Ya. (1984) Kategorii srednevekovoy kul'tury [Medieval Culture Categories]. Moskva: Iskusstvo [in Russian].

35. Korzh S. A. (2009) Fraghmentarna politychna kuljtura jak vyjav perekhidnogho periodu rozvytku ukrajinsjkogho suspiljstva [Fragmentary political culture as a manifestation of the transitional period of development of Ukrainian society] (PhD Thesis). Kyjiv: Nac ped. un-t im. M.P. Draghomanova [in Ukrainian].

36. Rjaboj Yu.O. (2012) Vplyv politychnoji kuljtury na transformacijni procesy ukrajinsjkogho suspiljstva [The influence of political culture on the transformation processes of Ukrainian society] ( $\mathrm{PhD}$ Thesis). Mykolajiv: Chornomor. derzh. un-t im. Petra Moghyly [in Ukrainian].

Information about the author: Chepik-Trehubenko Olha,

Candidate of Law, Associate Professor at the Department of General Legal Disciplines, Dnipropetrovsk State University of Internal Affairs 26, Gagarina Ave, Dnipro, Ukraine ORCID ID: orcid.org/0000-0001-5499-5793 


\section{GENERAL REGULARITIES OF THE DEVELOPMENT PROCESS OF THE HISTORY OF STATE AND LAW ACCORDING TO THE DOCTRINE OF GEORG WILHELM FRIEDRICH HEGEL}

\section{Oleksandr Holovko}

\section{INTRODUCTION}

Ukrainian historical and legal science has been going through a difficult and contradictory path over the last incomplete three decades from the postSoviet paradigm to broad pluralistic European approaches. The consciousness and methodological tools of a scholar, especially those from the Soviet times, as well as those formed in the traditions of the respective scientific school, were difficult to change. The simplicity and logic of Marxist methodological constructions remained familiar and comprehensible; moreover, they are attractive to new generations of scholars, not only in the history, but also in the theory of law and state, branch legal sciences. It is especially difficult both mentally and rationally for the national science of the history of law and state, to abandon the formative approach to the history of society, which makes the development of state and legal institutions natural and logical.

Absolutized formative approach to the history of law and state has led, in a number of cases, to a kind of "rounding", adapting to its provisions of certain unimpugnable or difficultly rebuttable facts, such as underdevelopment of slavery in the ancient Eastern states (so-called "domestic" or patriarchal slavery), and obviously the same prevalence of this phenomenon in the Old Rus' State, did not interfere to refer the first group to the slave-owning, and the second - to the feudal socio-economic formation. On the other hand, the theory of basis and superstructure defines law and state as secondary phenomena in regard to the socio-economic structure. According to this approach, the study of the most general, universal regularities of the development of law and state as social institutions is beyond the realm of legal reality within its historical dynamics. Hence, there is the desire to periodize the historical and legal process according to the chronology of state entities that existed by changing each other on a certain territory, which nowadays is the territory of really existing state.

Other universal approaches to general regularities of world history of law and state, in particular civilizational, are developed superficially, since the issue of the very existence of such regularities is very difficult from the standpoint of philosophy of law, and philosophy of history. Meanwhile, the solution of the task of searching for the general regularities of the historical 
and legal process requires not just a philosophical and legal, but a historical and legal approach, that is, the analysis of philosophical knowledge about the essence of the history of law and state, its orientation and content. It is important, in this context, to systematically analyze the answers to these largescale and "age-old" questions, provided by the most prominent philosophers of law from the past. The views of prominent German philosophers of the second half of the XVIII - first half of the XIX century occupy a worthy place among them.

The philosophical system created by Georg Wilhelm Friedrich Hegel (1770-1831) is fairly believed as ultimate of German classical philosophy. It is really one of the most versatile and universal. There are few such powerful products of intellectual activity in the New History of mankind that would try to explain and logically order all phenomena of both social medium and human nature, and the natural world in terms of a single system. One may call the names of Kant, Hegel, Spencer, Marx and Engels. At the same time, their titanic efforts have proved that it seems impossible to develop a philosophic system that would be single absolutely perfect and in no aspect irrefutable, not subject to logical and rationalistic critique. There is no sweepingly "the only true" doctrine and it can not be.

However, the critical mind must choose one of these global theories, get acquainted with all others, and apply it in accordance with one's own scientific worldview within the studies, in particular, within the history of law and state. Eventually, the methodology of scientific research, the main "production tool" of a researcher, is precisely formed and drawn in the depths of philosophical knowledge. Addressing to the Hegelian understanding of the history of law and state from this point of view is both relevant and timely and interesting, especially since this issue has not been covered specifically in Ukrainian legal science. Analysis of this problem constitutes the purpose of this research.

\section{Hegel's Views on the Development of Legal Phenomena within Historical Context}

There are few thinkers in the history of humanity, the attitude to whom would be as constant and controversial as to Hegel's scientific heritage, his ideas. The range is incredibly wide - from the acknowledgment of the ultimate in the world philosophical thought (there is no need to list scholars who had similar opinion about the German thinker, their hundreds, if not thousands, in different countries) up to the accusations in scientific fraud (A. Schopenhauer among contemporaries, K. Popper - the century ago). Like in every ideologically and meaningfully textually large and diverse acquisition, some researchers find, as they believe, justification for opposing 
things, as constitutional state and the police state, liberalism and totalitarianism.

Critical and cautious attitude to the Hegel's doctrine dominated in the Soviet scientific tradition, justified by the fact that K.H. Marx the creator of "the only true doctrine" thoroughly and consistently criticised Hegel's philosophy of law ${ }^{1}$. In particular, the founder of Marxism sought to prove that the convergence of the absolute spirit and the absolute mind in the state and legal sphere is Hegel's desire to justify private property and the monarchical system. Marx criticized the legal characteristics of particular societies, such as Ancient Rome and medieval estate society.

It is interesting that Marx, by raising objections against Hegel's philosophical understanding of law and its development, constantly appeals to the concept and content of the state. From his point of view, a man, a family and civil society are the components of the state. He noted that "State purpose" and "State power" in Hegel's philosophy were mystified, when they were declared as certain "ways of existence" of the substance, and they appeared to be detached from their real existence ..."

The collapse of the USSR, the formation of the independent state of Ukraine were accompanied by the transformation of scientific paradigms, in particular in the field of historical and theoretical jurisprudence. The Marxist monism of understanding social history, including the history of law and state (in its rather simplistic, Soviet, "Marxist-Leninist understanding") was replaced by philosophical, worldview and methodological pluralism. That also led to an unbiased view of the ideological opponents of Marxism. Both open access to neo-Hegelian concepts and rethinking of the original sources themselves were of interest. According to M. I. Pyliankevych, "We observe the final development of rationalism in Hegel's philosophy. The higher the desire of rationalism - to liberate oneself from any living content in nature and in the world of people, to reach the final point regarding abstract speculation, to spiritualize the world in the concept - it is completely fulfilled in Hegel's philosophy",3.

Hegel's philosophical and legal views are set out in a large array of his fundamental works. His ideas in concentrated form are contained in the monograph "Fundamentals of the Philosophy of Law or Natural State

\footnotetext{
${ }^{1}$ See: Marx K.H. (1927) K kritike gegelevskoj filosofii prava. Retrieved from: lugovoyk.narod.ru/marx/01/12.htm

${ }^{2}$ Ibid.

${ }^{3}$ Pilinkevich N.I. Istoriya filosofii prava. Filosofiia ta entsyklopediia prava $v$ Universyteti sviatoho Volodymyra: In 2 Vol. Kyiv: Lybid, 2011. Vol. 1. P. 273.
} 


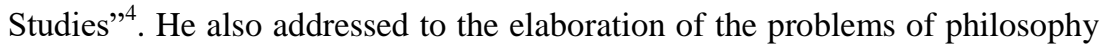
of history. The special work "Philosophy of History" is focused on that problem $^{5}$. It is generally accepted that the philosophical understanding of history by Hegel became the first universal scheme of the historical development of mankind. Hegel occupies a prominent place in the history of philosophical, political and legal thought. His ideas had a significant impact on further spiritual development around the world and gave a powerful impetus to new research in a variety of intellectual fields ${ }^{6}$.

The ideas and conclusions of the thinker also influenced the formation and development of the history of state and law as a science. First of all, he made an attempt to create unified philosophical scheme of history as universal, and secondly, he determined the philosophical content of such phenomena as law and state. All this created the basis for the development of the history of law, not just as a "descriptor" and "re-teller" of legal phenomena and facts, but created its unified concept. Understanding of law and history in terms of Hegel's dialectical philosophical system was extremely important for the development of the history of state and law as a science.

The creative heritage of the philosopher is extremely voluminous and diverse. All his works are intrinsically and substantively interconnected, that is why the philosophical and legal understanding of the history is presented in many of Hegel's works, including not very popular (mostly early ones). In 1798-1802 the young teacher paid great attention to the problems of the state and legal system of Germany. The result was the work of the "Constitution of Germany". "Hegel covered many issues there, including the history of the German Empire and its breakup into separate independent states (principalities, lands, etc.), the current state of affairs with statehood in Germany, the nature of relations between different states, European politics, war, future German state, etc."7. Naturally, the thinker begins his systematic study of the philosophical and legal characteristics of the history of one particular state (it is by ethnic, tribal and legal principle) - the German one. It is clear that he analyzes the regularities of his own homeland.

It is not a surprise that Hegel's main idea is centralistically national - he supports the unification of German state formations in one centralized state, and makes philosophical and legal conclusions and generalizations from historical and legal material from this angle. Herewith, the historical types of

\footnotetext{
${ }^{4}$ Hegel G.W.F. Osnovy filosofii prava abo pryrodne derzhavoznavstvo. Pereklad z nimetskoi R. Osadchuka ta M. Kushnira. K.: Yunivers, 2000.

5 Hegel G.W.F. Filosofiya istorii. Retrieved from: http://books.google.com.ua/books? $\mathrm{hl}=\mathrm{ru} \& \mathrm{id}=\mathrm{i} Y \mathrm{eNCwAAQBJ} \& \mathrm{oi}=\mathrm{fnd} \& \mathrm{pg}=\mathrm{PT}$.

${ }^{6}$ Nersesyants V.S. Filosofiya prava Gegelya. M.: Yurist, 1998. P. 5.

${ }^{7}$ Ibid. P. 15.
} 
public administration, finance, and justice for him in this work seem irrelevant to understanding the concept of the state. Here the philosopher distinguishes two main types of state - centralized in exercising state functions and decentralized.

It is the second type that seems attractive to the author, since according to G.W.F. Hegel it successfully combines the common interest and individual freedom of personality that the thinker, like his predecessors (Kant and Fichte), places at the center of his ethics and in general anthropological, legal, social constructions. The central state power in a decentralized state, gives its citizens freedom in everything that does not relate to the direct purpose of state power ${ }^{8}$.

The author expressed one of the pivotal ideas of his philosophical and legal, philosophical and historical doctrine in the "Constitution of Germany" that the state is the realization and convergence of the spirit in three stages (stages of the state and legal history of mankind):

- Eastern tyranny;

- republic;

- constitutional monarchy with a representative system.

He considered the latter to be German according to national and cultural nature, as the highest and most relevant to the ideas of society, man, his freedom. Hegel also argued that each nation must independently go through own cultural stages, before entering into the universal world correlation ${ }^{9}$. Thus, as we can see, the views of the philosopher coincide with the ideas of his contemporaries, representatives of the German Historical School of Law (see below).

"Historical Essays" (1797-1800) is another early work of Hegel, which is relatively unknown to scientific community. Here he makes a conclusion, interesting till now - about the fact when the social majority (lower class) becomes real actors in the historical and political reality. "... The moments when people behave actively, acquiring subjective qualities, are extremely interesting and important. Apparently, the history rarely offers such opportunities. Hegel calls two such points: the war (or rather, the direct battle) and the revolutionary protest against tyranny" ${ }^{\prime 10}$. That interest of the philosopher about the participation of the masses, social lower class in the creation of the history that mostly interested the Soviet scholars as representatives of orthodox-Marxist philosophy and the history of law.

\footnotetext{
${ }^{8}$ Ibid. P. 17.

${ }^{9}$ Ibid. P. 18-19.

${ }^{10}$ Karimskiy A.M. Filosofiya istorii Gegelya. M.: Izd-vo MGU, 1988 P. 12.
} 
The philosophical and legal views of the thinker are set out in the most holistic form; in the fundamental work "Fundamentals of the Philosophy of Law, or Natural Law and State Studies" (1821). The disclosure of the role and importance of the conceptual apparatus, its historical conditionality has great importance among its provisions for the methodological justification of historical and legal research: "... Every definition in law is dangerous. ... For example, the definition of a human being would be impossible for Roman law, because a slave would not fall under this definition...; the definition of ownership or owner would be also risky for many systems. Dermining the definition often derives from etymology, at least derived from it and abstracted from the specific cases, the basis of which are people's feelings and ideas. The correctness of the definition is determined through the comparison with existing ideas. ... Concepts in themselves and in their truth, and concepts in the imagination can and should differ in form and manner". This meant that historical and legal science had to operate with a clear conceptual apparatus, to have a specific and historical approach to it. Moreover, a similar approach to the concepts and definitions demonstrates the use of understanding of the dialectical interrelation of content and form.

The legal systems, according to Hegel, simultaneously have historical and national conditionality: "The law is generally positive: a) in the form of its validity in a certain state ... b) in content ... because of the special national character of the people, the stage of its historical development and through the interaction of all relations belonging to natural necessity ... Observing the progress and development of legal definitions over time is exlusevely historical task, as well as the study of their influence on thought, manifested in comparison with other legal relations"11. Thus, Hegel, through his dialectical analysis, like no one before, demonstrates the dynamism of historical and legal processes, changes in legal reality over time.

Thus, the philosopher is essentially the first who fully revealed not only the content of concepts, their speculative nature in science, but also the relationship of legal and historical in them. The meaning of Hegel's teachings resulted that the existence of the universal spirit is carried out in the world history in the full extent of its internal and external essence ${ }^{12}$. The law and state as manifestations of this spirit have the development of its manifestations, that is, the history. The national and historical character of law and its conceptual apparatus, according to Hegel's reasoned opinion, had one

11 Hegel G.W.F. Osnovy filosofii prava abo pryrodne derzhavoznavstvo. Pereklad z nimetskoi R. Osadchuka ta M. Kushnira. K.: Yunivers, 2000. P. 19-20.

${ }^{12}$ Pilinkevich N.I. Istoriya filosofii prava. Filosofiia ta entsyklopediia prava $v$ Universyteti sviatoho Volodymyra: In 2 Vol. Kyiv: Lybid, 2011. Vol. 1. P. 302. 
of the greatest manifestations of the spirit and will of the people in classical Roman law.

Here, he uses the findings of the founder of the German law school, G. von Hugo, concerning the studies of the latter on Roman civil law. Moreover, the philosopher, in our opinion, is ahead of time, giving in the analysis of Roman law a prototype of the concept of "living law", which was formed a century later in the writings of E. Ehrlich. This opinion is worded as follows: "... The inconsistency of Roman jurists and praetors should be regarded as one of the greatest advantages that made it possible to retreat from unjust and abhorrent institutions ..."13

However, this true and profound conclusion of the thinker on the importance of law enforcement within legal existence, he did not extend to the case law, without generalizing the importance of law making during law enforcement. In general, specific historical and legal stories sometimes give the thinker very subjective estimates. Thus, Hegel in his later work "Philosophy of the History", gave the following assessment for the English legal system: "In terms of private law, liberty of property, the English people are incredibly behind" $"$.

Hegel also paid attention to the elements of geographical determinism in the historical process. These conclusions, to some extent, have lost their scientific relevance today, although nowadays some scholars continue to share his point of view about the favorable climate of the mankind's civilizational development. "Philosophy of the History" like other Hegel's monographs and textbooks, contains many conclusions that have significant predictive value. Thus, given that the United States of America at the time was relatively sparsely populated, had a large reserve of vacant lands in the West, did not have borders with strong and developed, similar states, he pointed on the ungratefulness of the comparisons between the European states and the United States of America. "As a consequence, America is the country of the future ... those who are tired of the historical museum of ancient Europe are seeking this country" 15 .

But the predictability of Hegel's philosophy of law was not equally effective in all cases. Incidentally, we mention another philosopher's prediction about the state and legal development of mankind, which has not come true, and the beginning of the XXI century stressed it: "Islam having been pushed to Asia and Africa and tolerated in only one corner of the Europe

${ }^{13}$ Hegel G.W.F. Osnovy filosofii prava abo pryrodne derzhavoznavstvo. Pereklad z nimetskoi R. Osadchuka ta M. Kushnira. K.: Yunivers, 2000. P. 24.

${ }^{14}$ Hegel G.W.F. Filosofiya istorii. M.: Sotsekgiz, 1935. P. 421.

${ }^{15}$ Ibid. P. 81. 
due to the rivalry of Christian states, has long left the world historical arena and again returned to the Eastern calm and inviolability"16.

However, we do not analyze Hegel's prognostic achievements in this case, but his approaches to the history of state and law. It is difficult for a scholar to be a predictor, although it is known that K. Popper referred Hegel to the brightest representatives of the "philosophy of the oracles"

\section{Hegel's Dialectics and Historical and Legal Process}

Based on the fundamental positions of philosophical and legal subjectivism and dialectical understanding of both the deontic and the substantive sphere, creating a universal system of explaining the logic of the world's existence and development, Hegel had to be confronted with the issue of the internal regularities of the historical process concerning social, state and legal phenomena. He sought to study, logically derive and explain which engine is the driving force of the development of both law, and its concepts, and its history, and the state, and the human universe in general. On the one hand, "Law is something sacred in general already because it is the being of an absolute concept, of self-conscious freedom"18, and on the other, "Every stage of the development of the idea of freedom has its own law, since it is represented as being of freedom in one of its definitions"19. Thus, we see the development and own vision of the Kantian idea about the ascent to freedom as a sense of the history of law and state.

And the driving force is, of course, Hegel's dialectics: "The moving principle of the concept, not only destroying, but also generating the separation of the common, I call the dialectic... ...The higher dialectic of the concept is to consider the definition not only as a boundary and something opposite, but to generate positive content and positive result from it, which is the reason why it is the development and immanent promotion. Such dialectic is not the external action of subjective thinking, but the very soul of the content, which is the organic basis for its branches and fruits". The possibility of knowing the absolute spirit through its manifestations also means the possibility of knowing the history as the highest form of historical knowledge through the identification of causal relationships and regularities ${ }^{20}$.

\footnotetext{
${ }^{16}$ Ibid. P. 340.

${ }^{17}$ Popper K. Otkrytoye obshchestvo i ego vragi. Per. s angl. pod red. V.N. Sadovskogo. M.: Feniks. Mezhdunarodnyy fond «Kulturnaya initsiativa», 1992. Vol. 2. P. 16-17.

${ }^{18}$ Hegel G.W.F. Osnovy filosofii prava abo pryrodne derzhavoznavstvo. Pereklad z nimetskoi R. Osadchuka ta M. Kushnira. K.: Yunivers, 2000. P. 44.

${ }^{19}$ Ibid. P. 45.

${ }^{20}$ Karimskiy A.M. Filosofiya istorii Gegelya. M.: Izd-vo MGU, 1988 P. 59.
} 
Thus, a large-scale, comprehensive, scientific method of cognition was offered for current and further historical and legal studies, which retains its methodological relevance not only now, but also in the foreseeable future. The dialectical interrelation of legal phenomena and processes in their historical development, their causes, mechanism and direction, was the Hegel's answer to the question about the content and regularities of the history of state and legal institutions.

Moreover, the historical process both has its own regularities, and it is the highest law, but Hegel has observed the world history in indissoluble unity with the history of the state as an institution. We share the point of view of V.S. Nersesiants, who interpreted the thought of the German thinker: "The highest regularity of the history breaks its way through the peculiarities of states, peoples and individuals" ${ }^{\prime 21}$.

The notorious Hegel's triad, the first element of which is being ("being nothing - formation"), was necessarily applied both to law being and the mechanism of its transformation over time. From the point of view of law being, Hegel, in particular, formulated the concept of a combination of law making and law enforcement. In fact, the modern three-level understanding of the law being (law as ideas; law as norms; law as legal relations) is fully set forth in the writings of the German thinker.

He also creates a substantial basis for understanding law as a measure of not only of freedom, but also of human behavior. "An act becomes the expression of will as subjective or moral"22. It also brought the possibility of historical and legal knowledge to a qualitavely new level. The state of human legal consciousness is the determinant of legally significant activity of a person: "However, the law does not work, only the real person acts, and while evaluating human actions, according to this principle, one can talk about how much it has taken this law, how far it has entered into its beliefs" ${ }^{\text {"23 }}$.

In the hierarchy of special rights, constructed by G.W.F. Hegel, the state occupies the highest place, that is, according to V.S. Nersesiants, the most specific law is the state ${ }^{24}$. Thus, the law and state for the German thinker are correlated as more general and more specific - in fact there is a convergence from the concept of abstract law to the state as the most specific law, that is, from general to specific. Thus, methodological prerequisites were formed for the priority of law over the state as the subject of special historical research, and therefore the thinker not only formulated the theory of the rule of law

\footnotetext{
${ }^{21}$ Nersesyants V.S. Filosofiya prava Gegelya. M.: Yurist, 1998. P. 93.

${ }^{22}$ Hegel G.W.F. Osnovy filosofii prava abo pryrodne derzhavoznavstvo. Pereklad z nimetskoi R. Osadchuka ta M. Kushnira. K.: Yunivers, 2000. P. 107.

${ }^{23}$ Ibid. P. 127.

${ }^{24}$ Nersesyants V.S. Filosofiya prava Gegelya. M.: Yurist, 1998. P. 53.
} 
state, but also substantiated the rule of law principle from a philosophical point of view.

In our deep conviction, the Section of "Philosophy of Law", entitled "World History", is primarily concerned about the history of state and law. The history of material production or the arts hardly has a logical extension of the philosophical and legal discourse on the essence and content of law as a social phenomenon. The principal provisions are set forth by the thinker as follows: "... World history is not just a court, which is acted upon by the power of the world spirit, that is, by abstract and the need for a blind fate devoid of the sense, but if the world spirit is the mind in itself and for itself, but being of the mind in the spirit for itself - is knowledge, then the world history - it is necessary development of moments of mind only from the concept of freedom of spirit and, therefore, self-consciousness and freedom of spirit - interpretation and realization of the common spirit" ${ }^{\prime 25}$.

The dialectical development of the absolute spirit is, according to Hegel, the most profound and fundamental content of historical development, above all the changes of state and legal forms. Accordingly, Hegel defines the four basic (initial - as he calls them) principles and the corresponding four world "kingdoms" (roughly the same as what was later called formations or civilizations - depending on the fundamental historiosophical approach).

The content of these four principles can be most fully and accurately expressed in the words of the author:

"This self-consciousness in the first as direct revelation has its principle the image of the substantive spirit as an identity, where the singularity remains immersed in its essence and not justified for itself". The Eastern "kingdom" corresponds to this principle.

"The second principle is the knowledge of this substance spirit and the fact that it is a positive content, realization and being for itself as a living form of this content, a wonderful moral personality". The Greek "kingdom" corresponds to this principle.

"The third principle is intensification in the middle of oneself for being for itself to abstract generality, and thus to infinite opposition in regard to the equally abandoned spirit of objectivity". The Roman "kingdom" corresponds to this principle.

"The principle of the fourth formation is the transformation of this spirit's opposition, which consists in the fact that it perceives its true and concrete essence in its inner life and is at home concealed in objectivity; and since this spirit returned from infinite opposition, it knows own truth both as a thought

25 Hegel G.W.F. Osnovy filosofii prava abo pryrodne derzhavoznavstvo. Pereklad z nimetskoi R. Osadchuka ta M. Kushnira. K.: Yunivers, 2000. P. 292. 
and as a world of legitimate activity, and thus generates it" ${ }^{26}$. The German "world-historical kingdom" corresponds to this principle.

The historical process is a progressive stage development of the mind in the history ${ }^{27}$.

These ideas were developed in the "Philosophy of History" (1830). The scholar's conclusion about three types of historiography is determining for the development of both legal and general historiography:

- original history;

- reflective history;

- philosophical history.

Thus, we have the traditional for Hegel three-staged ascendancy from recording historical, historical and legal facts, descriptive historiography through analytical to philosophical understanding.

Hegel is primarily interested in the world history as the process occurring in the spiritual sphere, the world and historical process occurring reasonably and therefore in accordance with certain regularities. Since these are the regularities of spirit and mind's development, then a person is able to experience them. This requires:

- to find abstract definitions of the spirit's nature;

- to find out the means used by the spirit in order to realize its idea;

- to clarify the form of the complete realization of the spirit in the existing being - the state ${ }^{28}$.

Thus the thinker in the analysis of the world and historical process, like in case of philosophical and legal understanding of legal phenomena, emphasizes on the use of deductive method. He struck a certain blow to the empirical basis of the sciences of history and history of state and law in particular, which traditionally have to deal with facts, that is, single, special. However, this methodological contradiction, in our opinion, is removed, if this provision is applied only to the third of the above types of knowledge, namely the philosophy of history (in this case we can talk about the philosophy in general in the Hegelian sense, including the philosophy of law).

As an idealist, the scholar "ties" the objective history to the subjective one. "... There is no objective history for the centuries or millennia that preceded the historiography and when there were a series of revolutions, migrations, and in the highest degree turbulent changes, because they did not have a subjective history, a historical narrative. ... The considered actions

\footnotetext{
${ }^{26}$ Ibid. P. 205.

27 Hlushchenko H.Yu. Problema zakonomirnostei ystorycheskoho protsessa v fylosofyy Hehelia. Vestnyk Russkoi khrystyanskoi humanytarnoi akademyy. 2015. Vol. 16. Issue 3. P. 194.

${ }^{28}$ See: Hegel G.W.F. Filosofiya istorii. Retrieved from: http://books.google.com.ua/books? hl=ru\&id=iYeNCwAAQBJ\&oi=fnd\&pg=PT.
} 
accompanied by a clear consciousness about them developing the ability and the need to protect them in this form are realized only in the state, where the awareness of laws has been developed" ${ }^{29}$. Thus, the world history in the sense of Hegel is first of all the history of law and state.

Since the primary, pre-legal, and pre-state status of human society is not the object and subject matter of the study of the science of the history of state and law, then the most applicable to it it are Hegel's conclusions. So, according to his philosophy, the sense is the key interpreter of the meaning of the national state. The rational purpose of a man is to live in the state, and if there is no state yet, then there is a requirement of reason for it to be created ${ }^{30}$.

At the same time, a number of Hegel's historiographical provisions appear to be insufficiently substantiated. They include, in particular, the statement that history, like the sun, moves from East to West. By "fitting" the historiographical reality into its system, he sometimes makes very doubtful conclusions as to the present time, for example, that the Ancient Egypt borrowed its civilization, and therefore the law and the state ... in neighboring Ethiopia $^{31}$.

Considering the great popularity of Hegel's doctrine in the intellectual sphere of the Western world of the first half of the XIX century, we believe that such approaches of the great scholar also had their imprint on the science of the history of state and law, especially common at the time. It should be noted that later scholars of Hegel's scientific inheritance also had the question - why did the thinker pay so much attention to the history of the Ancient East, which is the least well-preserved (at least for European scholars)? "... He paid more attention to the East than to the Middle Ages and Modern Times, although he had lack of reliable historiographical material about the East, obviously, he took into account the awareness of listeners about European history issues" 32 .

The thinker pays tribute to the earliest interpretation of the content of the historical process and its periodization on the development of state and legal institutions - to correlate them with age specific features of human life. The first stage is the "childhood" of the history (the Ancient East), there is also "adolescence" within this epoch (it is the Front Asia, the Inter-Rivers and Persia, which are united by the geographical concept "Central Asia" - in the sense of Hegel it is not at all as nowadays Tashkent, Bishkek or Ashgabat). "Youth" - is Ancient Greece. "Maturity" is "... the kingdom of abstract

\footnotetext{
${ }^{29}$ Hegel G.W.F. Filosofiya istorii. M.: Sotsekgiz, 1935. P. 76.

${ }^{30}$ Grishchuk V.K. Filosofsko-pravovaya paradigma otvetstvennosti cheloveka: monograph. Khmelnytsky: Khmelnytsky University of Management and Law, 2015. P. 76.

${ }^{31}$ Hegel G.W.F. Filosofiya istorii. M.: Sotsekgiz, 1935. P. 189.

${ }^{32}$ Karimskiy A.M. Filosofiya istorii Gegelya. M.: Izd-vo MGU, 1988 P. 25.
} 
omnipotence; it is Roman state, the hard work of the age of history's maturity". And then "... there is the fourth moment of the world history: the German state; ... that would correspond to great age. Naturally, great age is a weakness, but the spirit's great age is its full maturity, where it returns to unity, but as a spirit" ${ }^{33}$.

Much attention Hegel paid to the analysis of all four eras ("kingdoms"). In our opinion, this part of his historical and legal research is specifically and historically conditioned. It had a great influence on contemporaries, but, over time, and with the expansion of knowledge of historians in the field of state and law on ancient times, particularly the Ancient East, this influence was significantly diminished. It is worth noting that one of the main sources in the history of Ancient Egypt for him was the work of Herodotus. However, with regard to ancient history, the philosopher provides a high and striking, even for modern historical and legal knowledge, a brief analysis of general regularities and the course of state and legal development of cities - the states of Ancient Greece and Ancient Rome.

Methodologically important is the conclusion that the need for the correspondance of legal system and the state system to public needs, about the possibility of filling the legal form with a completely different, sometimes opposite content. Hegel predicted to some extent the future extreme aspects of positivism: “... The great transition to empire has changed almost nothing in the constitution. Only the people's assembly no longer corresponded to the state of affairs and disappeared. The emperor was princeps senatus, censor, consul, tribune, he combined all these positions ... The Constitution was completely a non-substantive form, which became absolutely lifeless ...."34

The influence of Hegel doctrine on the development of the most important specific historical and legal subjects is not always mentioned today. Its addressing to the highest possible peaks of abstract thinking increased the angle of view on historical and legal issues, strengthened a critical component of the approach to such phenomena as Roman private law ${ }^{35}$, comprehensively studied by Hegel's contemporaries - representatives of the German Historical School of Law, which is going to be discussed further.

Hegel considered his current period - "the German world" as the most perfect from the point of view of realization of the absolute spirit. It refers to both German state and legal entities, and everything created by Germanic tribes, starting from the Goths and the Franks, the Anglians, the Saxons, the

${ }^{33}$ Hegel G.W.F. Filosofiya istorii. M.: Sotsekgiz, 1935. P. 103-104.

${ }^{34}$ Hegel G.W.F. Filosofiya istorii. M.: Sotsekgiz, 1935. P. 298.

${ }^{35}$ Mytiukov K.A. Kurs rymskoho prava. Rymske pravo $v$ Universyteti Sviatoho Volodymyra. In 2 books. Book 1 /Contributors I.S. Hrytsenko, V.A. Korotkyi; under the edition of I.S. Hrytsenko. K.: Lybid, 2010. P. 6. 
Alemans, etc. This epoch has received the most attention regarding the volume of the text. The author has defined the legal characteristics of theocracy, which the scholar did not consider the state in its full sense. At the same time the author has demonstrated the judicial system of the Carolus Magnus Empire, has addressed other historical and legal subjects, relatively private according to the set universal scientific task. He correctly interpreted feudalism as the absence of law in the traditional sense, as the law - the privileges and personal dependence of some feudal lords on others.

"The formation of states begins, while feudalism does not recognize any states" ${ }^{36}$. We believe that it is not the states in the whole as a social institution, but the national states that started to emerge with the advent of Modern Times. The next stage that the thinker considers as the most perfect - is the transition to the hereditary monarchy. There were three ways for that transition:

- the sovereign subordinates his independent vassals, destroys their demesnial ("particular") power and concentrates it in his hands;

- vassals are released from dependence and become sovereigns themselves in their possessions;

- the sovereign joins peacefully (for some reason the author - O.H. focuses his attention on this way) certain possessions to his individual possession.

In particular, Hegel pointed to a particular way of forming the English constitutional monarchy, noting the importance of the "Magna Carta" for the introduction of freedom and democratic values in England, the beginnings of parliamentarism: "...And Cities supported by the Kings against Barons, formed the third state and elected their representatives to the House of Commons"37.

Hegel considered the Reformation as the most significant event of the fourth epoch of the world history, which had a decisive influence on the legal system of modern states. It has assisted the Western world to overcome the lag of the world spirit. “... It is important to transfer all functions, duties and rights of the authority to the state's control that belongs to the state in accordance with its concept... Now, the system of states is objectively formed, and mutual relations between the states are established" ${ }^{38}$.

Hegel's opinion about the revolution was inspired by the success of the Reformation in England, Austria, Germany, Holland and its failure in France. Its content before the Jacobin dictatorship was that: "The real significance was

\footnotetext{
${ }^{36}$ Hegel G.W.F. Filosofiya istorii. M.: Sotsekgiz, 1935. P. 376.

${ }^{37}$ Ibid. P. 379.

${ }^{38}$ Ibid. P. 399-401.
} 
at once provided to the opinion, the concept of law, and the old boards, which were the basis for unfairness could not stand. Thus, a constitution was developed with the thought of law, and henceforth everything had to be based on it" ${ }^{39}$.

As we believe the elements of justification of the monarchical state system existed in Prussia at the time, the desire to give the religious character to the theory of the development of the absolute spirit, the consideration of its historical improvement as the only true theodicy - and many other things had historically conditioned nature and did not facilitate the universal process of improving theoretical and historical grounds of legal science. The history of law and state as a separate scientific specialty was only being formed at that time; it had the form of describing and commenting on state and legal phenomena. The state of that science of those days lagged behind in many aspects, from the great achievements of the philosophical, first of all, philosophical and legal, philosophical and historical system of Hegel. But the methodological basis was modern and for a long time.

\section{CONCLUSIONS}

1. An important contribution of G.W.F. Hegel into the formation of methodological principles and the very field of science of the history of state and law is raising attention to law as a unique social phenomenon, its removal from the shadow of state and political phenomena and institutions. Deep study of the philosophical discourse of law and its social content and significance, the formation of concepts of constitutional state and civil society have determined the way of development of historical and legal science in the world for centuries ahead.

2. The dialectical method, which had been offered by the scholar and thoroughly developed, further became the most heuristically powerful and applicable for the analysis of comprehemsive processes inherent in the history of law and state, finding the causes, sources and directions of its development, its regularities. We believe that the dialectical approach became the most effective basis for the development of the methodology of historical and legal research for the decades and centuries.

3. It is noteworthy that Hegel revealed the unity, orientation and regularity of the world history to the science, on the basis of the Kantian explanation of the historical process, in particular its state and legal component. Such a vision had an impact on the formation of all further concepts of the world (universal) history of law and state, without exaggeration.

\footnotetext{
${ }^{39}$ Ibid. P. 404.
} 


\section{SUMMARY}

The author has studied philosophical and legal views of G.W.F. Hegel in regard to the history of law and state. His universal philosophical system also covered the problems of historical development of state and legal phenomena and processes. Hegel's teaching on forming the modern methodology of historical and legal studies, in particular regarding the application of the dialectical philosophical approach to legal reality played an extremely important role. That made it possible to view the history of law and state as a dynamic process. The scholar offered a holistic conception of the history of law and state in the context of world history as the process of dialectical development of society; noted the role of the formation of a civil society and the rule of law state. Hegel distinguished four stages in the history of law and state: the Eastern (Ancient East), Ancient Greek, Ancient Roman and Germanic (he characterized the modern stage like that). The content of this process is the progressive development of the mind in the history. The thinker constantly and skillfully used specific historical and legal material in presenting his concept of historical process.

\section{REFERENCES}

1. Marx, K.H. (1927). K kritike gegelevskoj filosofii prava [Regarding the criticism of Hegel's philosophy of law]. Retrieved from lugovoyk.narod.ru/marx/01/12.htm [in Russian].

2. Pilinkevich, N.I., Hrytsenko, I.S., \& Korotkyi, V.A. (2011). Istoriya filosofii prava [History of philosophy of law]. Filosofiia ta entsyklopediia prava $v$ Universyteti sviatoho Volodymyra - Phylosophy and Enciclopedy of law in St. Vladimir University (Vols. 1), (pp. 101-306). Kyiv: Lybid. [in Russian].

3. Hegel, G.W.F. (2000). Osnovy filosofii prava abo pryrodne derzhavoznavstvo [Fundamentals of the philosophy of law or natural constitutional law]. (R. Osadchuk, M. Kushnir, Trans). K.: Yunivers [in Ukrainian].

4. Hegel, G.W.F (1935). Filosofiya istorii [Philosophy of the history]. Retrieved from http://books.google.com.ua/books?hl=ru\&id=iYeNCwAAQ BJ\&oi=fnd\&pg=PT [in Russian].

5. Nersesyants, V.S. (1998). Filosofiya prava Gegelya [Hegel's philosophy of law]. M.: Yurist [in Russian].

6. Karimskiy, A.M. (1988). Filosofiya istorii Gegelya [Hegel's philosophy of the history]. M.: Izd-vo MGU [in Russian].

7. Hegel, G.W.F. (1935). Filosofiya istorii [Philosophy of the history]. M.: Sotsekgiz [in Russian]. 
8. Popper, K. (1992). Otkrytoye obshchestvo i ego vragi [Open society and its enemies]. (V. Sadovskiy, Trans). M.: Feniks. Mezhdunarodnyy fond "Kulturnaya initsiativa" [in Russian].

9. Hlushchenko, H.Yu. (2015). Problema zakonomirnostei ystorycheskoho protsessa $\mathrm{v}$ fylosofyy Hehelia [The problem of regularities of the historical process in Hegel's philosophy]. Vestnyk Russkoi khrystyanskoi humanytarnoi akademyy - Bulletin of the Russian Christian Humanitarian Academy, 16 (3), 192-199 [in Russian].

10. Grishchuk, V.K. (2015). Filosofsko-pravovaya paradigma otvetstvennosti cheloveka [Philosophical and legal paradigm of human responsibility]. Khmelnytsky: Khmelnyts. un-t upravleniya i prava [in Russian].

11. Mytiukov, K.A., Hrytsenko, I.S., \& Korotkyi, V.A. (2010). Kurs rymskoho prava [The course of Roman law]. Rymske pravo $v$ Universyteti Sviatoho Volodymyra - Roman law in St. Vladimir University. (Book 1), (pp. 1-94). K.: Lybid [in Russian].

\section{Information about the author: Oleksandr Holovko, Doctor in Law, Professor,} Head of the State and Legal Subjects Department, School of Law of V.N. Karazin Kharkiv National University 4, Svobody Sq., Kharkiv, 61022, Ukraine ORCID ID: orcid.org/0000-0003-1770-9027 


\section{TAXPAYER CRITERION AS A GROUND FOR RECOGNIZING A LOCAL TAX RESIDENT AND VOTER AT LOCAL ELECTIONS}

\section{Nataliia Iakymchuk}

\section{INTRODUCTION}

The establishment of suffrage as a legal institution has come a long way, driven by the formation and development of legal doctrine, the history of the emergence of the principles and mechanisms of democracy in Europe, the recognition of universal suffrage and the consolidation of that principle and its guarantees at the international level.

The focus of the researchers is both the state of recognition and consolidation in law of all elements of suffrage, as well as the analysis of enforcement, those technical and bureaucratic barriers that do not allow a person to fully establish their rights in the electoral process.

Some issues of participation of citizens - internally displaced persons and foreigners in local elections in EU countries in Ukraine were investigated by M.M. Antonovich, V.I. Ivancho, A.V. Levenets, E.V. Tkachenko, O.V. Chernetska, and other scientists. However, such a circumstance as having by resident resident tax status with a fixed tax address, as well as a voter in local elections, which characterize their financial and political connection not only with the state but also with the relevant territorial community (municipality, commune, etc.)), remains mainly out of the researcher's attention.

\section{The emergence of the phenomenon of "tax exemptions" and refusal to recognize it at the constitutional level of universal suffrage}

The use of a wide range of electoral qualifications was characteristic of the period of "censorship democracy" prior to the constitutional implementation of the principle of universal suffrage, not limited by property (tax) qualification, the emergence of which is associated with the emergence of electoral law and the propagation of electoral theory, co-authored by the famous French politician B. Constant de Rebecque. According to this theory, only those individuals who have material well-being and proper education could be involved in the elections, which, in particular, provides them with freedom and independence in making the choice ${ }^{1}$.

\footnotetext{
${ }^{1}$ Shapoval V.M. (2005) Suchasniy konstitutsionalizm : monogr. [Modern Constitutionalism: monogr.], Kiev: Salkom. p. 319 [in Ukrainian]
} 
The electoral qualification (Latin census - valuation; property) is defined as a condition established by law for obtaining and exercising a suffrage by a citizen (active or passive). In the world practice, the most common was the property qualification (the need to own a set minimum of ownership) and the associated tax qualification.

Thus, in the Netherlands, the electoral law established by the Constitutions of 1798 and 1848 was burdened with a rather high tax standard. It was first abolished by the Constitution of 1887 and later by the laws of the 1990s.

In the United States, when the Constitution was adopted in 1787, all thirteen states had an economic qualification to vote: ten provided for ownership of property and three required tax payments. At the same time, the eligibility requirements were greatly reduced. For example, in Rhode Island, men who took the Oath of Freeman - acquired the right to vote if they owned real estate worth 40 pound sterlings or rented for 40 shillings a year; and in 1800, tax certification was commonplace and only three states (Kentucky, New Hampshire and Vermont) imposed universal suffrage, but only for white men. By 1830 , ten states had introduced universal suffrage without property or tax qualifications, but the other eight states restricted voting by taxpayers and a property qualification was imposed in six. In 1860, only five states retained the tax qualification and two states property ${ }^{2}$. Only in 1964, the 24th Amendment to the US Constitution was adopted, which prohibits states from depriving any citizen of the right to vote in certain elections, "as a result of non-payment of any poll tax or other tax". Since then, confirmation of permanent or temporary residence determines whether a person has the right to vote.

According to the Sardinian Constitution of 1848, the provisions of which later extended to the entire Italian kingdom, the right to vote belonged only to citizens who were twenty-five years of age and paid a tax of 40 francs $^{3}$.

In 1973, property and tax standards were imposed in Austria, and elections were held on curia, which limited the number of voters. Since 1896, the tax requirement has decreased, but only men who paid 8 korunas in direct taxes had the right to vote.

In France in 1791, only 16 percent of the adult population were eligible to vote. After the adoption of the Constitution in 1791, the property qualification was increased and the proportion of those eligible to participate in the elections was reduced to 8 percent, with the elections being indirect and two-

${ }^{2}$ Carol Berkin The Evolution of Voting Rights (2018). The Gilder Lehrman Institute of American history. www.gilderlehrman.org. Retrieved from https://www.gilderlehrman.org/ history-by-era/government-and-civics/essays/winning-vote-history-voting-rights

${ }^{3}$ Istoriya XIX veka. Konets veka, 1870-1900. (1939) Chast' 1. [History: The Nineteenth Century. End of the Century, 1870-1900. Part 1] / ed. E. Lavisse, A. Pambaud, E. Tarle. Moscow: State Economic and Social Publishing, p. 291. [in Russian]. 
stage. In 1817 , the election became direct, and the property qualification was set at 300 francs of direct tax (such a tax was paid by only 0.3 percent of the adult population of the country). The revolution in France in 1830 brought the reduction of property qualifications for the use of active suffrage up to 200 francs of direct tax. It was only as a result of the revolution of 1848 that universal suffrage was proclaimed in France, but since women and some other categories of citizens were not eligible to participate in the elections, no more than one third of the population could participate in the elections.

The tax requirement was also established by the Belgian Constitution in 1831 and was also quite high, in particular, 35-year-old men who were both homeowners and paid 1000 florins of direct tax held an active suffrage, and men of 25 years who paid a tax minimum of 20 florins; however, in different provinces the own size could be set. Only a wealthy taxpayer could be elected.

In Japan, on the basis of the Constitution of 1889, a sufficiently high tax standard was established. As a result, in the early twentieth century approximately 3 percent of the country's population were granted with voting rights.

Thus, at the beginning of the First World War, direct property and tax qualifications for active suffrage were maintained in several countries.

In the modern period, in some countries the tax qualification remains, but in a truncated form. In particular, regarding active suffrage, Article 29 (1) of the Constitution of the Kingdom of Denmark states: “... the law establishes in which cases criminal penalties and social assistance for poverty may be legitimate grounds for deprivation of suffrage." As a result, in some municipalities, persons who did not pay the municipal tax in time are not entered in the voter register. Other times, in some municipalities, persons who receive poverty relief or bankruptcy do not have the right to vote ${ }^{4}$. However, in individual states (Argentina, Norway, Canada), the tax qualification has been maintained solely with respect to passive suffrage ${ }^{5}$.

Instead, in the twentieth century, at the constitutional and international levels, the principle of universal suffrage was adopted, which did not provide for the possibility for states to establish an economic qualification (property or

\footnotetext{
4 Daniya: analiz izbiratel'nogo zakonodatel'stva $\mathrm{V}$ kontekste soblyudeniya obshchedemokraticheskikh standartov i prav cheloveka. (2009) [Denmark: analysis of electoral law in the context of observance of democratic standards and human rights.] Sait of CIS-Europe Monitoring Organization. venice.coe.int. Retrieved from http://www.cis-emo.net/ru/ materials/demokraticheskie-processy/daniya-analiz-izbiratelnogo-zakonodatelstva-v-kontekstesoblyudeniya-obshchedemokraticheskih [in Russian].

${ }^{5}$ Martselyak, O.V., Martselyak, S.M. (2015) Pravova pryroda y vydy tsenziv u vyborchomu pravi [Legal nature and types of qualifications in electoral law]. Konstytutsiyno-pravovi akademichni studiyi [Constitutional Law Academic Studies.], № 2, p. 110. [in Ukrainian].
} 
tax) and to promote the continued development of a set of electoral rights guarantees.

In the first stage of affirmation of the principle of universal suffrage in the world, voter status was generally recognized by citizens, but for local elections, voters were recognized by citizens according to their official place of residence. Almost all modern constitutions contain the provision that citizens have the right to vote. In particular, Article 70 of the Constitution of Ukraine establishes that citizens of Ukraine who have reached the age of eighteen have the right to vote in elections and referendums.

In the second stage, universal suffrage was recognized by citizens who, in the event of changing their actual place of residence, could declare their desire to participate in local (municipal elections) at their address.

\section{Establishing in the law of relationship between the tax address and the electoral address}

The constitution of Ukraine and international human rights standards clearly define the universality and equality of the rights of all citizens, in particular in matters of suffrage.

Important European standards for suffrage include the provisions of Article 3 of Protocol No. 1 (1952) to the The European Convention on Human Rights, which establishes the right to free elections and states: "The High Contracting Parties undertake to hold free elections at reasonable intervals by secret ballot, under conditions which will ensure the free expression of the opinion of the people in the choice of the legislature" $"$. Article 14 of the Convention prohibits discrimination on any ground such as sex, race, colour, language, religion, political or other opinion, national or social origin, association with a national minority, property, birth or other status ${ }^{7}$.

${ }^{6}$ Lenher Ya.I. (2016) Vyborchi prava vnutrishn'operemishchenykh osib v Ukrayini: koliziyni pytannya ta mozhlyvi shlyakhy yikh usunennya. [Voting Rights of Internally Displaced Persons in Ukraine: Conflict Issues and Possible Remedies]. Konstytutsiyno-pravovi akademichni studiyi [Constitutional Law Academic Studies], № 1, pp. 19-25 [in Ukrainian].

${ }^{7}$ Frants Macher (2004) Dopovid' pro skasuvannya obmezhen' prava holosu na zahal'nykh vyborakh, skhvalena Venetsians'koyu Komisiyeyu (Venetsiya, 3-4 hrudnya 2004 r.). [Franz Macher Report on the Abolition of Restrictions on the Right to Vote in the General Election of, approved by the Venice Commission (Venice, 3-4 December 2004).] Yevropeys'kyy demokratychnyy dorobok $u$ haluzi vyborchoho prava: Materialy Venetsians'koï Komisiï, Parlaments'koï Asambleï, Komitetu Ministriv, Konhresu mistsevykh i rehional'nykh vlad Rady Yevropy: per. $z$ anhl. / za red. Yu. Klyuchkovs'koho. [European democratic achievements in the field of suffrage : Proceedings of the Venice Commission, Parliamentary Assembly, Committee of Ministers, Congress of Local and Regional Authorities of the Council of Europe: trans. from English. / per row Y. Klyuchkovsky, Vyd. 2-e, vypr. i dopovn]. K., P. 140 [in Ukrainian] . C. 140. 
At the same time, the citizenship requirement for the right to vote or to be elected has never been challenged in court decisions, and the requirement of a certain period of residence has also been found admissible (Polacco and Garofalo / I, 1997).

The European Court of Human Rights has consistently emphasized that there is scope for natural restrictions within the scope of Article 3 of Protocol No. 1 and that States enjoy a wide margin of appreciation, of course, under the control of the Court.

However, measures taken by States should not infringe the very nature of the rights protected by Article 3 of Protocol No. 1. The measures under consideration should have a legitimate aim and not be arbitrary or disproportionate.

It is possible to conclude from the above recent judgments (Labita / I, 2002; Zadenoka / LV, 2004; Hirst / GB, 2004) that the Court is inclined to agree to restrictions only if they have a strong basis.

Thus, paragraph 9 of the Council of Europe Committee of Ministers' Recommendations of the Committee of Ministers to member states on internally displaced persons (2006) stipulates that Member states should take appropriate legal and practical measures to enable internally displaced persons to effectively exercise their right to vote in national, regional or local elections and to ensure that this right is not infringed by obstacles of a practical nature ${ }^{8}$.

Council of Europe Parliamentary Assembly Recommendation 1877 (2009) draws the attention of States to the need to ensure that "internally displaced persons can exercise their right to participate in public affairs at all levels, including their right to vote or stand for election, which may require special measures such as IDP voter registration drives, or absentee ballots (para. 15.3.12) ${ }^{9}$.

It should be noted that the development of the electoral law of Ukraine is at a specified stage, namely, the right to change the place of the election address, according to the voter's application, is being put into practice. Today, a motivated request of a voter to change the voting place of a citizen who has the right to vote in the relevant election or referendum can be carried out in the cases provided for in Art. 7 and 20 of the Law of Ukraine "On the State Voter Register" and Article 8 of the Law of Ukraine "On Ensuring the Rights and Freedoms of Internally Displaced Persons". However, these provisions

\footnotetext{
${ }^{8}$ Recommendation $\operatorname{Rec}(2006) 6$ of the Committee of Ministers to member states on internally Recommendation $\operatorname{Rec}(2006) 6$ of the Committee of Ministers to member states on internally displaced persons. rm.coe.int. Retrieved from https://rm.coe.int/16806b5aaf

9 Recommendation 1877 (2009) Parliamentary Assembly "Europe's forgotten people: protecting the human rights of long-term displaced persons". rm.coe.int. Retrieved from http://assembly.coe.int/nw/xml/XRef/Xref-XML2HTML-EN.asp?fileid=17759\&lang=en
} 
have not been reproduced in the provisions of the Law of Ukraine "On Local Elections".

However, Article 3 of the above-mentioned Law states that the right to vote in elections of deputies of a village, settlement, city council, election of a village, settlement, city mayor shall have citizens of Ukraine who have the right to vote under Article 70 of the Constitution of Ukraine, who belong to the respective territorial community and reside within the relevant constituency. Therefore, the criterion defines the belonging to the territorial community, which can be first of all confirmed by the fact that the person has defined the administrative-territorial point of the respective territorial community with his tax address.

\section{Dependence of the voter's legal status at local elections on recognition by the person of the status of the local tax resident according to the law of EU and Ukraine}

In the third historic phase, which began in the middle of the last century, universal suffrage was also recognized by foreigners, first and foremost EU nationals within the EU, and later by non-EU citizens who reside on a permanent basis or (and) are tax residents.

The right of EU citizens to vote and stand in local and European Parliament elections in their own countries is one of the aspects of European integration processes. Most EU countries have already introduced the electoral rights of foreigners in national law. In Belgium and Portugal, even citizens of Ukraine who live there have the right to choose local authorities.

Local elections can be a different matter. Eleven states have statutes that permit nonresidents, such as second-home owners or business owners, to vote in local, municipal, and/or special district elections such as irrigation, water, sewer and conservancy districts. There are: 1) three states allow nonresident voting in municipal or town elections: Connecticut, Delaware, New Mexico; 2 ) ten states allow nonresident voting in certain special district elections. New Mexico and Delaware have provisions allowing nonresidents to vote in special district elections in addition to municipal elections: Arizona, Arkansas, California, Colorado, Delaware, Nebraska, New Mexico, Oregon, Tennessee, Wyoming ${ }^{10}$.

In recent years, property owners across the country have called for the extension of suffrage for non-residents. Relying on John Adams' argument, they claim that their economic interest in a particular community gives them the right

${ }^{10}$ Voting by Nonresidents. (2018) The Gilder Lehrman Institute of American History. 6.20.2018. Retrieved from http://www.ncsl.org/research/elections-and-campaigns/non-residentand-non-citizen-voting.aspx 
to speak in local affairs. Attempts have been made to counter this trend. For example, in Del, Connecticut, residents of the city have come to court over this issue, claiming that non-residents are diluting their voting authority. The court held that the statute had a "sound basis" for the extension of suffrage to nonresidents and was thus decided in favor of the property owners.

Since then, the impulse has increased in other places. In 1995, this movement was the most diverse, and the resort town of Mountain Village, Colorado has approved a statute that allows non-residents to vote if they own at least 50 percent of the ownership of the local property.

One of the important international instruments enshrining the electoral rights of non-citizens is the Council of Europe Convention on the Participation of Foreigners in Public Life at Local Level, which has been ratified by only nine states, including Denmark, Finland, the Netherlands, Norway and Sweden, but Ukraine is now among the Council of Europe member states that have not yet ratified the Convention. In particular, Art. 6 of the Convention states that "Each Party undertakes, subject to the provisions of Article 9, paragraph 1 (concerning permissible restrictions during a war or other state of emergency in the country which threatens the life of the nation), to grant to every foreign resident the right to vote and to stand for election in local authority elections, provided that he fulfils the same legal requirements as apply to nationals and furthermore has been a lawful and habitual resident in the State concerned for the 5 years preceding the elections. However, a Contracting State may declare, when depositing its instrument of ratification, acceptance, approval or accession, that it intends to confine the application of paragraph 1 to the right to vote only" 11 .

According to Venice Commission's Code of Good Practice in Electoral Matters $\left.^{12}: 1\right)$ universal suffrage means in principle that all human beings have the right to vote and to stand for election; 2) This right may, however, and indeed should, be subject to certain conditions, which include residence: that is, the state may require residence, while it is recommended to allow foreigners who reside in the locality for a longer period to participate in local elections (CDL-AD (2004) 040, para. 9). A similar recommendation of the Parliamentary Assembly also applies to the participation of foreigners in local referendums (Recommendation 1704 (2005), paragraph 13.vi.c). However, some member states of the Council of Europe have not yet implemented a general recommendation, which of course requires some administrative effort.

\footnotetext{
${ }^{11}$ Convention on the Participation of Foreigners in Public Life at Local Level. Strasbourg, Council of Europe 5.II.1992. rm.coe.int. Retrieved from https://rm.coe.int/168007bd26

${ }^{12}$ Guidelines on Elections. Adopted by the Venice Commission at its 51st Plenary Session (Venice, 5-6 July 2002). venice.coe.int. Retrieved from https://www.venice.coe.int/webforms/ documents/CDL-AD(2002)013-e.aspx
} 
Thus, Member States should pursue policies that are consistent with the Council of Europe's goals, but there is no legal obligation to follow ideas stemming from the various legally non-binding instruments (resolutions, recommendations) of the Council of Europe institutions, including the Code of Good Practice in Electoral Matters (Venice Commission document of July 2003). The same applies to the 1992 Convention on the Participation of Foreigners in Public Life at Local Level, until it has been ratified.

The right of participation of foreigners and stateless persons in elections is enshrined in the sources of European Union law, in particular Article 19 of the Treaty establishing the European Community, in Art. 10 (former Article 8a) of the Treaty on European Union, which provides that "Every citizen shall have the right to participate in the democratic life of the Union. Decisions shall be taken as openly and as closely as possible to the citizen"13. In Art. 8b of Part Two of the Treaty on Nationality states that "every citizen of the Union residing in a Member State of which he is not a national shall have the right to vote and to stand as a candidate at municipal elections in the Member State in which he resides, under the same conditions as nationals of that State" ${ }^{\text {.14 }}$. Most Member States have enshrined in national law the suffrage of EU citizens who do not have the nationality of their country of residence, both in elections to the EU Parliament and in local elections, but in some cases EU countries, in particular, Bulgaria and Latvia have not yet fully implemented these rules. So, "ODIHR expressed respective concerns in Bulgaria where resident foreigners were not granted right to vote in local elections. A recommendation was also made in Latvia to grant non-citizens a right to vote in local elections" $" 15$.

Detailed measures for the exercise of the right to vote and to nominate candidates for municipal elections are laid down in Council Directive 94/80/EC, which states that the right to vote and to participate in the elections of candidates for municipal elections in the Member State of residence contained in Article 8b (1) of The Treaty establishing the European Community is an example of the application of the principle of equality and unlawfulness, discrimination between citizens and non-citizens and the

${ }^{13}$ Treaty on European Union (Maastricht, 7 February 1992) - Consolidated version 2007. www.cvce.eu. Retrieved from https://www.cvce.eu/en/obj/treaty_on_european_union_maastricht_ 7_february_1992_consolidated_version_2007-en-e92737d6-7557-4ea1-9ca5-123368a7fb88.html

${ }^{14}$ Treaty establishing the European Community - part two: citizenship of the Union - article $8 \mathrm{~b} / *$ Codified version of the treaty establishing the European Community. Official Journal. eur-lex.europa.eu. p. 224, 31/08/1992 p. 0011. Retrieved from http://eur-lex.europa.eu/legalcontent/RO/TXT/?uri=CELEX:11992E008B

${ }^{15}$ Review of Electoral legislation and Practice in OSCE participating states. OSCE, Office for Democratic Institutions and Human Rights (Warsaw, October 15, 2013). www.osce.org. Retrieved from www.osce.org/odihr/elections/107073?download=true 
consequence of the right of free movement and residence enshrined in Article 8a of this Treaty.

Any derogation from the general rules of this Directive must be justified, in accordance with Article 8b (1) of the Treaty, by problems specific to the Member State; given that any deviation should, by its nature, be revised. Directive 94/80 / EC states that such specific problems may arise in a Member State in which the proportion of Union citizens of the voting age, who reside in it but are not citizens of it, is very much above the average. Such a circumstance is justified when such citizens make up more than $20 \%$ of the total number of voters; however, such derogations from a Member State should be based on residence criteria ${ }^{16}$.

Regarding the participation in local and regional elections, if the stipulated period of residence does not exceed several months, the residence requirement does not seem to be contrary to the principle of universal suffrage; the establishment of a longer term is permissible only for the protection of national minorities (decision of the European Commission on Human Rights No 23450/94 of 15.09.97 in the case of Polacco and Garofalo v. Italy (concerning Trentino-Alto Adige)).

It is important to note that the Venice Commission Interpretation Directive states that states may "Registration could take place where a voter has his or her secondary residence, if he or she resides there regularly and it appears, for example, on local tax payments; the voter must not then of course be registered where he or she has his or her principal residence"17. It is clear that in this case, voter registration at the main residence is not allowed.

We would like to emphasize that the fact of voter recognition of the taxpayer to the local budget, at the expense of which the functions are performed and the tasks of local self-government are accomplished, is a fact of belonging of the person to the territorial community, his/her financial participation in joint solving of problems of the residents of the respective administrative-territorial unit.

Recognition of a person as a tax resident, and especially a regional tax resident whose tax address does not correspond to the official place of registration - is, in our opinion, sufficient reason for recognizing the person as

${ }^{16}$ Council Directive 94/80/EC of 19 December 1994 laying down detailed arrangements for the exercise of the right to vote and to stand as a candidate in municipal elections by citizens of the Union residing in a Member State of which they are not nationals. eur-lex.europa.eu. Retrieved from http://eur-lex.europa.eu/legal-content/EN/TXT/HTML/?uri=CELEX:31994 L0080\&from $=\mathrm{EN}$

${ }^{17}$ Explanatory report adopted by the Venice Commission at its 52nd Plenary Session (Venice, 18-19 October 2002). Europian commission for democracy through law (Venice commisson). www.venice.coe.int. CDL-AD(2002)023rev2-cor. p. 14. Retrieved from https://www.venice.coe.int/ webforms/documents/default.aspx?pdffile=CDL-AD(2002)023rev2-cor-e 
a member of the territorial community. In this case, the polling address must match the voter's tax address.

Paragraph 5 of Council of Europe Parliamentary Assembly Resolution 1459 (2005) on the abolition of restrictions on voting rights of 24 June 2005 states that all legal residents are normally obliged to pay local taxes and their lives are directly affected by the decisions of local authorities. The right to vote and to stand as candidates in local elections should therefore be granted to all legal residents having lived long enough in the country, regardless of their nationality or ethnic origin. In this context, the Assembly urges the countries concerned to implement the recommendations by the Council of Europe Commissioner for Human Rights on granting that right to residents with the special status of "non-citizens", in accordance with the Convention on the Participation of Foreigners in Public Life at Local Level.

Residents are accounted for as taxpayers in state registers that are separate from the voter register or combined into a single state register. Voter registration can be either automatic or by application, which is relevant for citizens of the state who belong to the circle of internally displaced persons, as well as for non-citizen residents, if the voter register and the register of taxpayers are not combined in a single state register. However, in individual states, people must register before they can vote or stand as a candidate in an election, which is seen not as a restriction on universal suffrage, but as a component of the way it is exercised.

Directive 94/80/EC provides that Member States, where voting is optional, may adopt an automatic voter registration system. This is already happening in Austria (except Burgenland), Denmark, Estonia, Finland, Germany, Hungary, Latvia, Lithuania, Malta, the Netherlands, Romania, Slovakia, Slovenia and Sweden, Chile and several other countries. Such practices will not create an additional burden for citizens who wish to exercise their right to vote, since they are not required to submit a new application for registration during the imperative restriction.

Typically, voter registries are updated using a variety of sources, including tax authorities. Thus, in Canada it is the Canadian Revenue Agency, in Denmark it is the National Register used for tax and election lists kept by the Ministry of Welfare (Velfærdsministeriet). In Finland, a change of address in the register is automatically registered by all other public authorities (eg local tax authority, social security authorities, etc.). In Norway, a national register (Folkeregisteret,) is used for tax lists, voter lists, membership of a unified health care system and other purposes, and is maintained by the tax authorities ${ }^{18}$.

${ }^{18}$ Yevropeys'kyy vyborchyy dorobok [European Electoral Achievement]. CDL (2002) 7 rev (f). www.venice.coe.int. Retrieved from https://www.venice.coe.int/files/CDL-elec-opinionsUKR.pdf [in Ukrainian]. 
Ukraine also provides for automatic registration of citizens as voters. According to Art. 8 the voter's electoral address is the address at which his place of residence is registered in accordance with the Law of Ukraine "On Freedom of Movement and Free Choice of Residence in Ukraine", in accordance with Art. 6 of which a citizen of Ukraine, as well as a foreigner or stateless person permanently or temporarily residing in Ukraine, is obliged to register their place of residence within thirty calendar days after withdrawal from registration of residence and arrival at a new place of residence, as a result of which information is entered in the Register of Territorial Communities (Art. 11-2).

A motivated request to change the voting place of a citizen who has the right to vote in the relevant election or referendum, in accordance with the Law of Ukraine "On the State Register of Voters" is possible: 1) without changing the electoral address, ie with the purpose of temporary (for the period of their holding), change of the polling station for the voter, but not later than five days before the day of voting in the respective election or referendum (part 3 of Article 7 of the Law), which does not give the right to vote in local elections at the specified polling station, but only at national elections; 2) with change of the electoral address, the voter who: a) in case of change of his personal data (part 1 of Article 20 of the Law), submits to the body of keeping the Register at the new electoral address an application to which documents (copies of documents) confirming the change of voter's electoral address (Part 2 of Article 20) b) has no registered place of residence (Part 3 of Article 8 of the Law), but appeals with a reasoned request, the acceptance of which gives him the right to exercise active suffrage both in the Ukrainian and local elections.

In the case of a voter's request for a change of election address, the Register authority examines the validity of the application (Part 20 of Article 20 of the Law). The Register authority may check the change of the voter's personal data specified in the application by contacting the relevant bodies, institutions, institutions referred to in Article 22 of this Law.

In accordance with the provisions of Article 8 of the Law of Ukraine "On Ensuring the Rights and Freedoms of Internally Displaced Persons", an internally displaced person (a person who has been forced to leave or abandon their place of residence as a result of or to avoid the negative effects of armed conflict, temporary occupation, pervasive acts of violence, human rights abuses and natural or man-made emergencies) exercises his/her right to vote in elections of the President of Ukraine, Peoples' Deputies of Ukraine, local elections, and referendum by changing the place of voting without changing the election address in accordance with Part 3 of Art. 7 of the Law of Ukraine "On the State Voter Register". However, the fact that without changing the 
election address, the IDP has the right to participate in local elections on an equal footing with other members of the territorial community to which he / she temporarily belongs, has not developed in the provisions of the Law "On Local Elections".

However, Article 3 of the Law of Ukraine "On Local Elections" states that the right to vote in the elections of deputies of village, town, city council, elections of village, town, mayor shall be vested in the citizens of Ukraine who have the right to vote under Article 70 of the Constitution of Ukraine, who belong to the relevant territorial community and reside within the respective constituency. Therefore, the criterion is not so much the electoral address as the belonging to the territorial community.

It is important that the request (application) to change the electoral address should occur exactly to the Register authority at the new electoral address (Part 2 of Article 20 of the Law), similarly, when it comes to changing the polling station. However, the following are of concern: 1) the list of bodies that provide information to the State Voter Register authority does not mention the bodies of income and fees (fiscal bodies) that keep information cards of individuals-taxpayers, containing information about the tax address of citizens and foreigners, which are entered into these cards at the request of such person who can determine as his tax address his place of actual residence or place of residence, which is registered in the State Demographic Register; 2) the question remains: whether for the legislator of Ukraine is sufficient argument for recognition of a person as a member of a territorial community that he has a tax address at his place of actual residence, since according to Article 64 of the Budget Code of Ukraine it is the budget of a territorial community of an administrative-territorial unit, at which the tax address of an individual is recognized, is received in the appropriate share, paid by him/her income tax without the intermediary of the tax agent, which certifies its financial participation in the life of the territorial community and local self-government.

European practitioners solve the problem of exercising active suffrage in the following way: voting by mail (Greece, Belgium, the United Kingdom), proxy voting (Netherlands, France, Belgium), and the most progressive way voting via the Internet (tested in Estonia, Portugal and France) ${ }^{19}$.

Estonia is now the most successful example. In 2000, an electronic identification card was introduced in the country. Every adult of the country has it, like a passport. It allows to control bank accounts, use an electronic signature, file a tax return, pay for transportation services in major cities, travel to EU countries, and more recently participate in elections.

19 Recommendation $\operatorname{Rec}(2006) 6$ of the Committee of Ministers to member states on internally displaced persons. rm.coe.int. Retrieved from https://rm.coe.int/16806b5aaf 
In Ukraine, the law about ID cards has already been adopted and may also become an opportunity to vote in the future.

Thus, in Ukraine there are delimited: Unified demographic register (the register of citizens); registers of territorial communities (places of official registration of a person); Unified voter register; register of taxpayers (tax address of individuals), register of insured persons (individuals who are insured in the system of compulsory state social insurance), register of displaced persons who do not agree among themselves and correction of information in one of them does not cause automatic changes in the in other cases, and in some cases, it is the responsibility of the citizen to apply to make changes to the said resets in case of their change to permanent or temporary residence.

\section{CONCLUSIONS}

Thus, the criterion of payment by the voter of the tax, which in the first stage of the establishment of suffrage played the role of restriction, that is, the tax qualification, became a significant factor (a kind of legal guarantee) of recognition of an individual (first and foremost a citizen, and in some states a foreigner), who has active and passive right to elections of a certain level (local, nationwide, to the EU Parliament). Accordingly, when improving the national electoral legislation, it is necessary to take into account the tax address factor as much as possible when determining the election address of an individual, as well as to take into account the data of the State Register of Individuals of Taxpayers in the automatic and application procedure of the State Register of Voters.

Thus, in the course of establishing the universal suffrage in view of the voter being recognized as a taxpayer in the country of residence, there was: 1) a waiver of the tax qualification; 2) distribution of suffrage, first and foremost, to all citizens regardless of their change to permanent or temporary residence; 3) a recommendation has been introduced, and for EU Member States the obligation to grant voting rights to non-residents who are permanently resident and recognized as residents; 4) removing barriers to the exercise of voter rights and minimizing compulsory registration by filing petitions by persons who has voting rights and are residents, which is facilitated by the practice of establishing a single state register based on the register of taxpayers and insured persons and unification of tax and election addresses of persons with suffrage.

Of course, in every state there is a complex of difficulties of philosophical, political, historical, static, demographic, etc. nature, which leads, first, to civil society disputes about the expediency and timeliness of expanding both the number of persons to whom electoral rights are recognized and the guarantees of such rights, and secondly, to their implementation in law and in practice. However, the European choice of Ukraine necessitates the gradual 
consolidation of the principle of universal suffrage in its modern sense, by means of unification and harmonization of national electoral law with EU law, as well as bringing it into line with international standards, while respecting the interests of the statehood of Ukraine at every step.

\section{SUMMARY}

The article explores the stages of the formation of universal suffrage, namely from the abolition of the tax qualification to the recognition and consolidation of universal and equal suffrage at the constitutional level. The state of recognition of universal suffrage in the sources of international law, European Union legal documents, as well as the experience of legal fixing at the level of laws in a number of countries of the world the right to participate in local elections for foreign residents of the host country are analyzed. The influence of the criterion of foreigners paying taxes to the local budget, recognition of their belonging to the territorial community and the status of the local tax resident on the recognition of their right to participate in local elections are investigated. The state of fulfillment by the European Union Member States of their obligations to ensure that foreigners - tax residents exercise their voting rights in local elections - is highlighted. The problems of realization by the citizens of Ukraine by forced temporary internal migrants of their right to vote in local elections to local self-government bodies of the territorial community of which they are temporary members are investigated. The problematic issues of fixing the voting rights of foreigners - tax residents in local elections in the legislation of Ukraine are covered. It was emphasized that the criterion of payment by the voter of the tax, which in the first stage of election rights played the role of restriction, ie the tax qualification, became a significant factor (a kind of legal guarantee) recognition of an individual (above all a citizen, and in some states a foreigner) as a person who owns active and passive right to elections of a certain level (local, nationwide, to the EU Parliament). Accordingly, in improving the national electoral law, it is necessary to take into account the tax address factor as much as possible when determining the electoral address of an individual, and when forming in the automatic and application procedure of the State Voter Register to take into account the data of the State Register of Individuals Taxpayers.

\section{REFERENCES}

1. Shapoval V.M. (2005) Suchasniy konstitutsionalizm : monogr. [Modern Constitutionalism: monogr.], Kiev: Salkom. 559 p. [in Ukrainian].

2. Carol Berkin The Evolution of Voting Rights (2018). The Gilder Lehrman Institute of American history. www.gilderlehrman.org. Retrieved from https://www.gilderlehrman.org/history-by-era/government-and-civics/ essays/winning-vote-history-voting-rights 
3. Istoriya XIX veka. Konets veka, 1870-1900. (1939) Chast' 1. [History: The Nineteenth Century. End of the Century, 1870-1900. Part 1] / ed. E. Lavisse, A. Pambaud, E. Tarle. Moscow: State Economic and Social Publishing, 340 p. [in Russian].

4. Daniya: analiz izbiratel'nogo zakonodatel'stva v kontekste soblyudeniya obshchedemokraticheskikh standartov i prav cheloveka. (2009) [Denmark: analysis of electoral law in the context of observance of democratic standards and human rights.] Sait of CIS-Europe Monitoring Organization. venice.coe.int. Retrieved from http://www.cis-emo.net/ru/materials/demokraticheskieprocessy/daniya-analiz-izbiratelnogo-zakonodatelstva-v-kontekste-soblyudeniyaobshchedemokraticheskih [in Russian].

5. Martselyak, O.V., Martselyak, S.M. (2015) Pravova pryroda y vydy tsenziv u vyborchomu pravi [Legal nature and types of qualifications in electoral law]. Konstytutsiyno-pravovi akademichni studiyi [Constitutional Law Academic Studies.], № 2, pp. 91-123. [in Ukrainian].

6. Lenher Ya.I. (2016) Vyborchi prava vnutrishn'operemishchenykh osib v Ukrayini: koliziyni pytannya ta mozhlyvi shlyakhy yikh usunennya. [Voting Rights of Internally Displaced Persons in Ukraine: Conflict Issues and Possible Remedies]. Konstytutsiyno-pravovi akademichni studiyi [Constitutional Law Academic Studies], № 1, pp. 19-25 [in Ukrainian].

7. Frants Macher (2004) Dopovid' pro skasuvannya obmezhen' prava holosu na zahal'nykh vyborakh, skhvalena Venetsians'koyu Komisiyeyu (Venetsiya, 3-4 hrudnya 2004 r.). [Franz Macher Report on the Abolition of Restrictions on the Right to Vote in the General Election of, approved by the Venice Commission (Venice, 3-4 December 2004).] Yevropeys'kyy demokratychnyy dorobok $u$ haluzi vyborchoho prava: Materialy Venetsians'koï Komisii, Parlaments'koï Asambleï, Komitetu Ministriv, Konhresu mistsevykh i rehional'nykh vlad Rady Yevropy: per. z anhl. / za red. $Y$ Y.Klyuchkovs'koho. [European democratic achievements in the field of suffrage : Proceedings of the Venice Commission, Parliamentary Assembly, Committee of Ministers, Congress of Local and Regional Authorities of the Council of Europe: trans. from English. / per row Y. Klyuchkovsky, Vyd. 2-e, vypr. i dopovn]. K., 500 p. [in Ukrainian].

8. Recommendation $\operatorname{Rec}(2006) 6$ of the Committee of Ministers to member states on internally displaced persons. rm.coe.int. Retrieved from https://rm.coe.int/16806b5aaf

9. Recommendation 1877 (2009) Parliamentary Assembly "Europe's forgotten people: protecting the human rights of long-term displaced persons". rm.coe.int. Retrieved from http://assembly.coe.int/nw/xml/XRef/XrefXML2HTML-EN.asp?fileid=17759\&lang=en

10. Voting by Nonresidents. (2018) The Gilder Lehrman Institute of American History. 6.20.2018. Retrieved from http://www.ncsl.org/research/ elections-and-campaigns/non-resident-and-non-citizen-voting.aspx 
11. Convention on the Participation of Foreigners in Public Life at Local Level. Strasbourg, Council of Europe 5.II.1992. rm.coe.int. Retrieved from https://rm.coe.int/168007bd26

12. Guidelines on Elections. Adopted by the Venice Commission at its 51st Plenary Session (Venice, 5-6 July 2002). venice.coe.int. Retrieved from https://www.venice.coe.int/webforms/documents/CDL-AD(2002)013-e.aspx

13. Treaty on European Union (Maastricht, 7 February 1992) - Consolidated version 2007. www.cvce.eu. Retrieved from https://www.cvce.eu/en/obj/ treaty_on_european_union_maastricht_7_february_1992_consolidated_version_2 007-en-e92737d6-7557-4ea1-9ca5-123368a7fb88.html

14. Treaty establishing the European Community - part two: citizenship of the Union - article $8 \mathrm{~b} / *$ Codified version of the treaty establishing the European Community. Official Journal. eur-lex.europa.eu. P. 224, 31/08/1992 P. 0011. Retrieved from http://eur-lex.europa.eu/legal-content/RO/TXT/?uri= CELEX:11992E008B

15. Review of Electoral legislation and Practice in OSCE participating states. OSCE, Office for Democratic Institutions and Human Rights (Warsaw, October 15, 2013). www.osce.org. Retrieved from www.osce.org/odihr/ elections $/ 107073$ ?download=true

16. Council Directive 94/80/EC of 19 December 1994 laying down detailed arrangements for the exercise of the right to vote and to stand as a candidate in municipal elections by citizens of the Union residing in a Member State of which they are not nationals. eur-lex.europa.eu. Retrieved from http://eur-lex.europa.eu/legal-content/EN/TXT/HTML/?uri=CELEX: 31994L0080\&from $=\mathrm{EN}$

17. Explanatory report adopted by the Venice Commission at its 52nd Plenary Session (Venice, 18-19 October 2002). Europian commission for democracy through law (Venice commisson). www.venice.coe.int. CDL$\mathrm{AD}(2002) 023$ rev2-cor. P. 14. Retrieved from https://www.venice.coe.int/ webforms/documents/default.aspx?pdffile $=$ CDL-AD(2002)023rev2-cor-e

18. Yevropeys'kyy vyborchyy dorobok [European Electoral Achievement]. CDL (2002) 7 rev (f). www.venice.coe.int. Retrieved from https://www.venice.coe.int/files/CDL-elec-opinions-UKR.pdf [in Ukrainian].

Information about the author: Nataliia Iakymchuk,

Doctor of Science (Law), Professor, Professor at the Department of Financial Law, Law Faculty, Taras Shevchenko National University of Kyiv Kyiv, Ukraine ORCID ID: orcid.org/0000-0002-4848-2323 


\section{THE LATEST TRENDS OF ANNULMENT OF THE COMMERCIAL ARBITRATION AWARDS IN UKRAINE: GROUNDS, APPROACHES, CONSEQUENCES}

\section{Yuliya Kabrera}

\section{INTRODUCTION}

The history of arbitration nascence reaches the millennia. There is an opinion that the arbitration arose together with appearing of the trade relations, which in turn, off course, leads to dispute-resolution issues, and the main guarantee of successful trade provides settlement of such disputes in a peaceful way. A qualitative litigation method - international arbitration arose already in the Ancient World, in order to resolve controversies between medieval merchants in marketplaces in Europe and Mediterranean and Baltic sea trade. The intense usage of commercial arbitration became achievable only after it acquired a modern look and legal backing in The English Arbitration Act 1889. This act actually meant that Courts were empowered to enforce parties' agreement to arbitrate and established basic foundations of arbitration: voluntary participation in arbitration, the right of all citizens who have signed the contracts to court, as well as the arbitration rules. It was later adopted by arbitration statutes in most countries of the British Commonwealth ${ }^{1}$.

The pace of development of international relations is gradually accelerating, globalizing and unifying. Interaction with a foreign element is a big integral part of our lives. With the growth of international trade, the demand for the settlement of international commercial disputes is directly proportional. The main purpose of commercial arbitration is to resolve disputes between the parties on the basis of substantive rules of substantive law, on foreign trade contracts, misunderstandings arising in the process of cooperation, companies of different nationalities and states in any specific legal relationship. There is an extremely high demand for commercial dispute resolution through international arbitration tribunals around the world, generated by the efficiency of arbitration proceedings.

It is worth mentioning that positive and favorable to arbitration court practice is in an overwhelming majority in Ukraine. The author, however,

\footnotetext{
${ }^{1}$ Sait of electronic encyclopedia "The new Encyclopedia Britannica" [Sait of encyclopedia "The new Encyclopedia Britannica"]. britannica.com. Retrieved from https://www.britannica.com/topic/arbitration [in English].
} 
does not aim to cover it, but rather draft the attention to some peculiarities that might be a challenge for potential recognition and enforcement. With this deep analyzes of the Ukrainian legal practice and set aside arbitration awards for the last few years, we can determine trends, directions, or special traits/features of the Ukrainian legal system. In this way we will have a full picture of how the Ukrainian system works and what obstacles lawyers and parties of the dispute can face. International arbitration rules, mixed with the Ukrainian national ones, can create a coherent hybrid whose functional existence, in the author's view, is impractical and fictitious, since it is inconsistent with generally accepted norms of international arbitration practice.

Knowing such debatable special features (that are used for the annulment of the arbitral awards in Ukraine) of the Ukrainian legal machine in advance, and deep understanding of their effects and consequences on both: setting aside the award and legal arbitration practice in general, we can prevent all possible options for the abolition of arbitral awards of a controversial, ambiguous and unreliable nature and, which is even more important, to set a vector of a neutral, predictable, fruitful and resultative justice in Ukraine.

The main grounds for the cancellation of arbitral awards and for the refusal to recognize and enforce them are enshrined in transnational and national laws. The New York Convention of 1958 (hereinafter - the NY Convention), whereto 159 states are parties, including Ukraine since $1960^{2}$, seeks to unify general approaches to recognition and enforcement of arbitral awards and establishes the main reasons for setting aside, refusal to recognize and enforce arbitral awards in the countries that have ratified the convention. Grounds for cancellation and refusal of recognition were also reflected word by word in Art. 459 of the Code of Civil Procedure of Ukraine (hereinafter the CPC of Ukraine) $)^{3}$ and in Art. 34, 36 of the Law of Ukraine "On International Commercial Arbitration" (hereinafter - the ICA Act) ${ }^{4}$ created on the basis of the UNCITRAL Model Law. The analysis of the current court practice over the past few years will be based on the provisions of Art. 5 of the NY Convention.

2 Convention "On the Recognition and Enforcement of Foreign Arbitral Awards" [Convention "On the Recognition and Enforcement of Foreign Arbitral Awards"] (n.d.) newyorkconvention.org. Retrieved from http://www.newyorkconvention.org/list+of+ contracting+states [in English].

3 Tsyvilnyi protsesualnyi kodeks Ukrainy [Ukrainian Code of Civil Procedure] (n.d.) kodeksy.com.ua. Retrieved from https://kodeksy.com.ua/tsivil_nij_protsesual_nij_kodeks_ ukraini/459.htm [in Ukrainian].

${ }^{4}$ Zakon Ukrainy "Pro mizhnarodnyi komertsiinyi arbitrazh" [The Law of Ukraine "On

International Commercial Arbitration"]. (n.d.) zakon.rada.gov.ua Retrived from https://zakon.rada.gov.ua/laws/show/4002-12 [in Ukrainian]. 


\section{The arbitration agreement is not valid under the law to which the parties have subjected it}

This was the ground for setting aside the award in LG Electronics Ukraine $v$ Ant Yapi $^{5}$, considered by the Supreme Court. Two companies, LG Electronics Ukraine and Ukrnekstpulbrut, concluded a contract for the sale of goods whereunder Ukrnekstpulbrut purchased goods and undertook to pay their cost. The contract contained an arbitration clause.

Ant Yapi firm provided security for due performance by Ukrnekstpulbrut of its payment obligation under the contract in favor of LG Electronics Ukraine. Ant Yapi and LG Electronics Ukraine (the creditor) entered into a suretyship agreement, according to the terms of which the guarantor, Ant Yapi, took on a commitment to bear the full responsibility of Ukrnekstpulbrut (the debtor) to the creditor for all obligations under the sale contract concluded earlier. Also, the parties had an additional agreement to the suretyship agreement, which contained the arbitration clause.

Ukrnekstpulbrut failed to perform its payment obligation and LG Electronics Ukraine filed claims against both the principal debtor and the surety with the International Commercial Arbitration Court at the Ukrainian Chamber of Commerce and Industry (hereinafter - the ICAC at the UCCI). The dispute was subjected to the Ukrainian law, which had been chosen by the parties. At some point, LG Electronics Ukraine requested the tribunal to direct all its claims only to Ant Yapi rather than to Ukrnekstpulbrut. The ICAC at the UCCI terminated proceedings against Ukrnekstpulbrut and ultimately monetary claims against Ant Yapi were granted.

Being unsatisfied with the final award, Ant Yapi wanted to set it aside in the competent Court of Ukraine. Ant Yapi emphasized that the additional agreement to the suretyship agreement, which contained the arbitration clause, was concluded in English and Russian with the latter prevailing in case of discrepancies. At the same time, only English (namely non-prevailing) version of the agreement was duly signed by the parties. On that ground, Ant Yapi requested the Court to find that the arbitration clause was invalid since the prevailing version of it was not signed by the parties. Ukrainian Court considered the matter and set aside the final award, reasoning that the arbitration Court did not have the competence to consider the dispute, because there was no actual arbitral agreement between the parties.

5 Sprava "LG Electronics Ukraine v Ant Yapi Sanayi Ve Ticaret Anonim Shirketi no. 761/605/17-ц" [Case LG Electronic Ukraine v Ant Yapi Sanayi Ve Ticaret Anonim Shirketi № 761/605/17-ц]. (n.d.). reyestr.court.gov.ua. Retrieved from http://www.reyestr.court.gov.ua/ Review/70416292 [in Ukrainian]. 
Such decision was based on Art. 547 of the Civil Code of Ukraine (hereinafter - the CC of Ukraine), according to which a juridical act to secure the fulfillment of an obligation must be made in writing and juridical act is null and void if it is not made in written form. In accordance with Art. 207 (2) of the CC of Ukraine, a juridical act is considered to be done in writing, if it is signed by the party (parties). Also, in accordance with Art. 215 of the CC of Ukraine, it is necessary for the local Courts to distinguish types of invalidity of juridic acts: void acts - if their invalidity is established by law (and there is no need in recognition or proof of this fact in a Court) and disputed acts - if their nullity is not directly established by law, but one of the parties or other interested person denies their validity on the grounds established by law ${ }^{6}$.

So, the logic of the Court meant that the juridic act was null and void because of its non-compliance with the requirements of the law. In our case, the written form is the requirement of the Ukrainian law and this written form means signed agreement. The Russian variant (prevailing version) of the additional agreement to the suretyship agreement was not signed, so, in the Court's opinion, it was not made in written form. Hence, the additional agreement to the suretyship agreement was null and void and thus, there was no actual arbitration agreement between the parties.

One more document was used in The Court's reasoning - The Resolution № 12 of the Plenum of the Supreme Court of Ukraine of 24 December 1999 "On practice of consideration by courts of motions for recognition and enforcement of foreign courts' awards and arbitral tribunals' awards and on annulment of awards rendered by international commercial arbitration courts in the territory of Ukraine" (hereinafter - the Resolution № 12). According to Art. 20 of the Resolution № 12, only on the condition that if the parties have, in a written contract or arbitration clause, manifested their agreed will to resolve their disputes in arbitration tribunal, the court may consider that the arbitration tribunal has competence ${ }^{7}$.

Virtually, in our opinion, it looks as if the Court of Ukraine, construed this resolution № 12 in it’s own very specific way, which means that if the parties

${ }^{6}$ Tsyvilnyi kodeks Ukrainy [The Civil Code of Ukraine]. (n.d.). zakon.rada.gov.ua. Retrived from https://zakon.rada.gov.ua/laws/show/435-15 [in Ukrainian].

${ }^{7}$ Postanova no. 12 Plenum verkhovnoho sudu Ukrainy "Pro praktyku rozghliadu sudamy klopotan pro vyznannia y vykonannia rishen inozemnykh sudiv ta arbitrazhiv i pro skasuvannia rishen, postanovlenykh u poriadku mizhnarodnoho komertsiinoho arbitrazhu na terytorii Ukrainy" [The Resolution no. 12 of the Plenum of the Supreme Court of Ukraine "On practice of consideration by courts of motions for recognition and enforcement of foreign courts' awards and arbitral tribunals' awards and on annulment of awards rendered by international commercial arbitration courts in the territory of Ukraine"]. (n.d.) zakon.rada.gov.ua Retrived from https://zakon.rada.gov.ua/laws/show/v0012700-99 [in Ukrainian]. 
have not concluded an arbitration agreement in writing, no arbitral tribunal has the legitimacy to arbitrate their case at all.

Eo ipso, the Court ruled that there was a legal relationship between two companies on the grounds of a suretyship agreement, which by its legal nature was a juridical act to secure the performance of the obligation and, therefore, had to be in writing. The court reasoned that if the additional agreement was not in writing, it was null and void and, hence, the arbitral tribunal did not have legitimacy and thus, the competence to resolve the dispute.

In our opinion, this annulment looks very controversial and generates lots of questions for further discussion. Firstly, the approach used by the Court to set aside the award in the above mentioned case contradicts the Ukrainian legislation itself in three aspects.

The first is, because of the Art. 218 (2) of the CC of Ukraine which has the provision that if the juridical act, for which the law establishes its invalidity in case of non-compliance with the written form, has been concluded verbally and one of the parties has performed an action and the other party has confirmed it, in particular, by the way of acceptance of its enforcement, such a juridical act in case of a dispute can be recognized by the court as valid ${ }^{88}$. So, in this way, I can assume, that the failure to comply with a simple written form of the juridical act does not entail the invalidity of the latter, but only complicates the proof of its existence.

The second aspect is that Ukraine, like most countries, adheres to the principle of "competence - competence" and enshrines this principle in Art. 16 (1) of the Law of Ukraine "On ICA" . The basic provision of the "competence - competence" principle is that the judges of the arbitral tribunal is authorized or has the competence to decide by themselves on the validity of the arbitration clause from which it extracts its prerogative power to resolve the dispute ${ }^{10}$. Therefore, I consider resolving issues about the competence of the arbitral tribunal is out of the jurisdictional sphere of the state Ukrainian Courts at all.

And the third, in our vision, this Court's decision denies the existence of "separability" concept. That means, if the arbitration tribunal thinks that the

${ }^{8}$ Tsyvilnyi kodeks Ukrainy [The Civil Code of Ukraine]. (n.d.) zakon.rada.gov.ua Retrived from https://zakon1.rada.gov.ua/laws/show/435-15/ed20120618 [in Ukrainian].

9 Zakon Ukrainy "Pro mizhnarodnyi komertsiinyi arbitrazh" [The Law of Ukraine "On International Commercial Arbitration"]. (n.d.) zakon.rada.gov.ua Retrived from https://zakon.rada.gov.ua/laws/show/4002-12 [in Ukrainian].

${ }^{10}$ Phillip Landolt, The Inconvenience of Principle: Separability and Kompetenz-Kompetenz (2013) [The Inconvenience of Principle: Separability and Kompetez-Kompetenz] Journal of International Arbitration, (Vols 30), (pp. 511-530). The Netherlands: Kluwer Law International BV [in English]. 
contract which includes the arbitration clause is invalid, it can still rule on its own jurisdiction and decide the dispute under the invalid contract ${ }^{11}$. This idea comes from the notion of the "separability" of the arbitration agreement from the main contract Art. 16 (1) Model Law and Article 16 (1) of the Law of Ukraine "On ICA", an arbitration clause which is an integral part of a contract shall be treated as an independent agreement. The decision by the arbitral court that the contract is null and void shall not entail ipso iure the invalidity of the arbitration clause ${ }^{12}$.

The matter of arbitration agreement validity was also raised in Naumann Machyny i Pallety v Bruma case ${ }^{13}$. Naumann Machyny i Pallety and Bruma entered into an investment contract, which concerned transfer of equipment. The investment contract provided for resolution of all disputes thereunder by the German Arbitration Institute (the DIS). When the dispute arose, Naumann Machyny i Pallety filed claims with the DIS requesting that the equipment is returned and damages are paid.

Before the final award in the case was rendered, Naumann Machyny i Pallety requested that the tribunal imposes interim measures upon Bruma to limit its capacity to dissipate assets. The interim measures were granted and Naumann Machyny i Pallety moved to enforce them at the place of residence of the debtor. At the recognition and enforcement stage Bruma denied validity of DIS arbitration agreement having submitted to the court a written addendum to the main contract, according to which all disputes had to be resolved by the ICAC at the UCCI.

The Ukrainian courts considered the matter and ruled that DIS did not have jurisdiction to consider the dispute They ruled, furthermore, that such a dispute cannot be considered by either the arbitral tribunal at the place where the plaintiff is located, nor by the ICAC at the UCCI, as it is impossible to give preference to one or another body for consideration of the dispute. Under such circumstances, the courts opined, the arbitration agreement cannot be performed and the dispute mentioned above should be considered by the state

${ }^{11}$ Ronán Feehily, (2018). Separability in international commercial arbitration; confluence, conflict and the appropriate limitations in the development and application of the doctrine [Separability in international commercial arbitration; confluence, conflict and the appropriate limitations in the development and application of the doctrine] Arbitration International, 34. Retrived from https://academic.oup.com/arbitration/article-abstract/34/3/355/5098414 [in English].

${ }^{12}$ The UNCITRAL Model Law [The UNCITRAL Model Law]. (n.d.) uncitral.un.org. Retrived from https://uncitral.un.org/en/texts/arbitration/modellaw/commercial_arbitration [in English].

${ }^{13}$ Sprava "Naumann Machyny i Pallety v Bruma № no. 159/4966/15-ц " [ Case Naumann Machyny i Pallety v Bruma № no. 159/4966/15-ц ] (n.d.). reyestr.court.gov.ua. Retrieved from http://www.reyestr.court.gov.ua/Review/63323683 [in Ukrainian]. 
court at the place of residence of the respondent and there was no other legal way out of this situation.

\section{The party against whom the award is invoked was not given proper notice of the appointment of the arbitrator or of the arbitration proceedings and was otherwise unable to present his case}

The proper notice issue is usually invoked at the setting aside and enforcement stages and court practice shows that this ground may be one of the most successful given the Ukrainian court being rather formalistic in their approaches. One of the cases concerned recognition and enforcement of a DIS award for interim measures in support of the pending arbitral proceedings in Naumann Machyny $i$ Pallety $v$ Bruma case already considered in section I above.

Besides, the double inconsistent arbitration clause issue, Bruma also claimed that it was not duly notified of the arbitral proceedings. In particular, in the present case the documents were send per registered post, however it was impossible to establish who was the sender of the notification (the letter bore no reference to DIS, case number etc).

Naumann Machyny i Pallety insisted that the notification originated form one of the arbitrators however could not provide satisfactory proof to support its position. Having considered the matter, the courts ruled that postal dispatch, however per registered e-mail, has to be sent by the institution or an authorized official to be considered a due notification.

Another case, in which due notification was considered by the court, concerned enforcement of LCIA arbitral award in Sea Emerald S.A. v Sudnobudivny zavod imeni 61 comunara case ${ }^{14}$. By concluding a contract for execution of construction works and sale of a refrigerator vessel, the parties agreed that any disputes arising within the scope of that contract shall be submitted to arbitration and would be governed by the law of England and LMAA Rules. The contract provided that all notifications and communications between the parties would be made per post to specified postal addresses. The arbitration clause included parties' phone numbers and faxes, but not e-mail addresses.

The procedure for considering arbitration disputes in England is governed by The Arbitration Act 1996 (hereinafter - The Law). In accordance with paragraph 76 (1) of The Law, the parties are free to agree on the method of

14 Sprava "Sea Emerald S.A. V Sudnobudivny zavod imeni 61 comunara case no. 1423/15646/2012" [Case Sea Emerald S.A. v Sudnobudivny zavod imeni 61 comunara no. 1423/15646/2012]. (n.d.). reyestr.court.gov.ua. Retrieved from http://www.reyestr.court.gov.ua/ Review/62203095 [in Ukrainian]. 
delivery of notices and other documents ${ }^{15}$. Thus, the laws of England provide for the right of the parties to decide on the method of delivering documents.

The Supreme Court of Ukraine came to the conclusion that in determining whether the notification was properly made the Court had to proceed from the relevant procedures specified by the parties in the arbitration clause. By prior agreement on the method of delivery of the documents, the parties did not foresee the use of electronic notifications and there were no e-mail addresses of Sea Emerald S.A. and Sudnobudivny zavod imeni 61 comunara specified in the contract. Such a method of documents delivery or other notices that was not agreed by the parties in the contract could not be considered appropriate and, therefore, the recognition and enforcement of the arbitral award was denied.

\section{The composition of the arbitral authority or the arbitral procedure was not in accordance with the agreement of the parties, or, failing such an agreement, was not in accordance with the law of the country where the arbitration took place}

The issue of the tribunal composition arose between Nussed Serbia d.o.o. $v$ Kompaniia RAIZ case $^{16}$ when in the submission of a dispute for consideration to ICAC at the UCCI each party independently chose the same person to act as an arbitrator, while the contract signed between the parties provided for all disputes thereunder to be considered by two arbitrators under the ICAC at the UCCI Rules $^{17}$. In such circumstances, the President of the ICAC at the UCCI, despite the arbitration agreement between the participants in the dispute, decided that the case had to be considered by the sole arbitrator instead of two.

Having received an unfavorable decision, the respondent in the case referred to a domestic Court to set aside the award because the arbitral tribunal was formed in violation of the parties' agreement. The Ukrainian Court considered the matter and ruled that two arbitrators were foreseen and the parties did not change the terms of the contract by choosing the same person but only chose an arbitrator, one from each side, without knowing that they had chosen the same person. Ukrainian Court grounded its decision stating that the ICAC chairman did not have any legal power to make changes in the quantitative composition of the court by his own decision contrary to the provisions of the arbitration clause. On the contrary, he had to propose to both parties of the process a candidacy of the second arbitrator.

${ }^{15}$ The Arbitration Act 1996 [The Arbitration Act 1996]. (n.d.). legislation.gov.uk. Retrived from https://www.legislation.gov.uk/ukpga/1996/23/section/76 [in English].

${ }^{16}$ Sprava "Nussed Serbia d.o.o. v Rise Company case no. 761/5425/16-ц" [ Case Nussed Serbia d.o.o. v Rise Company case no. 761/5425/16-ц ]. (n.d.). reyestr.court.gov.ua. Retrieved from http://www.reyestr.court.gov.ua/Review/71534619 [in Ukrainian].

17 The ICAC at the UCCI Rules 2018 [The ICAC at the UCCI Rules 2018]. (n.d.). icac.org.ua Retrived from https://icac.org.ua/en/arbitrazh/reglament/ [in English]. 
Plea of Nussed Serbia d.o.o. that Kompaniia RAIZ waived its right to object because the latter continued participating in the arbitration proceedings without objecting to the change of the arbitrator, was the subject matter of investigation of a cassation Court. However, the Court did not accept such arguments of the party as proper.

In my opinion, cancellation of the award in the case described above looks rather doubtful because one of the basic principles of the Model Law is bona fides, fairness in the use of procedural rights vested in the parties. The manifestation of this principle is the waiver of the right to object by virtue of Art. 4 of the Model Law and Art. 4 of the Law of Ukraine "On ICA". According to those articles, a sanction is imposed on the party who did not use the time reasonably given to it for raising objections under certain conditions, namely on the basis of general principles such as estoppel or venire contra factum proprium (to act against one's own previous conduct $)^{18}$. That means that the party was given a special period of time for raising any objections, but if this party did not use its own right to object during the time given to it and proceeded with the arbitration, such party will be precluded from raising any objections or invoking the non-compliance as a ground for setting aside the award, or from using objections as a reason for refusing to recognize and enforce the award after it had been rendered, as it was vividly interpreted in analytical commentary to Art. 4 on draft Model Law on international commercial arbitration ${ }^{19}$.

Similar issue of tribunal composition arose in SES Astra ABv Ukrkosmos $\operatorname{case}^{20}$. A contract between SES Astra AB and Ukrkosmos contained arbitral agreement according to which any disputes must be resolved by a panel of three arbitrators under the Rules of ICC. When the arbitral proceedings were commenced, SES Astra AB suggested to the Secretariat that the dispute is considered by the sole arbitrator. The Secretariat notified the matter to Ukrkosmos. Ukrkosmos in its reply to SES Astra AB suggestion stated that it would not object to the case being submitted to the sole arbitrator provided that the two parties would manage to agree upon its candidacy. Apparently, no agreement was reached between the parties, but the Secretariat nevertheless submitted the case to the sole arbitrator.

${ }^{18}$ Reinhold, Steven, Good Faith in International Law (2013). [Good Faith in International Law] Journal of Law and Jurisprudence, 2. Retrived from https://ssrn.com/abstract=2269746 [in English].

19 Analytical Commentary on Draft Text of a Model Law on International Commercial Arbitration A/CN.9/264 [Analytical Commentary on Draft Text of a Model Law on International Commercial Arbitration A/CN.9/264]. (n.d.). mcgill.ca Retrived from https://www.mcgill.ca/ arbitration/files/arbitration/Commentaireanalytique-en.pdf [in English].

${ }^{20}$ Sprava SES Astra AB v Ukrkosmos no. 757/34281/14-ц [Case SES Astra AB v Ukrkosmos no. 757/34281/14-ц ] (n.d.). reyestr.court.gov.ua. Retrived from http://www.reyestr.court.gov.ua/ Review/62960687 [in Ukrainian]. 
First instance court refused recognition and enforcement. Appellate court, when revoking the refusal, considered that Ukrkosmos was duly notified of the proceedings, arbitrator's appointment and even informed the tribunal of its legal representative and requested extension for presenting its case. In such circumstances, opined the appellate court, Ukrkosmos had all reasonable opportunities to present its case and, among others, to object to tribunal formation, and having failed to do so, Ukrkosmos is barred from doing it at the recognition and enforcement stage.

Cassation court, when considering the matter and the ruling of which is final and binding, did not agree with the appellate court and noted as follows: irrespective of the notification of and attorney appointing by Ukrkosmos, regard has to be given to the fact that Ukrkosmos did not file any submission on the merits of the case. Thus, Ukrkosmos cannot be considered as barred from filing objections on jurisdiction, including those related to the number of arbitrators, considering its case. Since Ukrkosmos had a right to claim inadequate tribunal formation, such argument had to be considered by the court.

In considering the formation of tribunal issue, the cassation court noted that Ukrkosmos's consent to sole arbitrator was strictly conditional upon his joint nomination by the parties. Since such joint nomination was unsuccessful, the case ought to have been referred to the panel of three judges as provided for in the contract. The cassation has therefore ruled, that the award could not be recognized and enforced, the tribunal having been formed in violation of parties arbitration agreement provisions.

One more case that may fall within the present category deals with the mandatory pre-litigation dispute settlement procedures, entered into by the parties. In the case the obligatory pre-trial settlement of a dispute, which excludes the possibility of filing a statement of claim before it is complied with, is in place, failure to observe all the steps may be treated as violation of the arbitral procedure, agreed upon by the parties.

The mandatory out-of-court dispute settlement procedures agreed upon in agreements entered into by the parties in the case Odeskyi morskyi torhivelnyi port $v$ International Port Services Ltd ${ }^{21}$. The decision rendered by the ICAC in favor of Odeskyi morskyi torhivelnyi port was set aside. The reason for the cancellation was neglect of the necessity to conduct initial pre-trial settlement negotiations as a mandatory prerequisite prior to arbitration, as it was required by the arbitral agreement of the parties. In response to the claim, the Ukrainian Court proceeded

21 Sprava "Odessa Sea Commercial Port v International Port Services Ltd case no. 6-18634св07" [Case Odessa Sea Commercial Port v International Port Services Ltd case no. 6-18634св07]. (n.d.). reyestr.court.gov.ua. Retrieved from http://www.reyestr.court.gov.ua/ Review/ 1603221 [in Ukrainian]. 
from the fact that when the arbitral tribunal adjudicated a dispute, the arbitration procedure was violated, since the fact of observance of the terms of the arbitration clause and the pre-trial settlement of the dispute was not verified by the arbitral tribunal. There was no evidence of bilateral pre-trial negotiation between the parties on the subject matter of the dispute. In the consideration of the matter, the Supreme Court of Ukraine analyzed the arbitration agreement between the parties and ruled that the negotiation was mandatory and verified that materials carried no evidence of the bilateral pre-trial negotiations.

Thus, the necessity of conducting initial pre-trial settlement negotiations, as a mandatory prerequisite prior to arbitration, was neglected. With that, the Supreme Court of Ukraine found that the arbitration procedure was not in conformity with the agreement between the parties and set aside the award.

The above-discussed case is very demonstrative because, in my opinion, there is no common strategy or procedure in the Ukrainian legal practice to solve mediation issues. The first proof to support my idea is that there is no law about mediation in Ukraine. The latest attempt of the Ukrainian parliament to vote for the bill on mediation № 3665 failed in $2019^{22}$. Thus, the main question that arises is to what extent the preliminary negotiation before the lawsuit is mandatory? To answer this question it is worth discussing an example from legal practice about mediation issues.

The Constitutional Court of Ukraine rendered the decision for pre-trial settlement of disputes known as the case Campus Cotton Club ${ }^{23}$. The Constitutional Court of Ukraine reasoned that the provisions of Art. 124 (2) of the Constitution of Ukraine must be considered in a systemic connection with other provisions of the Constitution that provide legal guarantees for everyone to protect their rights and freedoms of man and citizen by any means not prohibited by Art. 55 (5) of the Constitution of Ukraine. In the opinion of the Constitutional Court, each person has the right to freely choose any means of protecting rights and freedoms that are not prohibited by law, including judicial protection. Those provisions ensure implementation of the constitutional right to judicial protection, which right can not be restricted even under conditions of martial law or state of emergency in accordance with Art. 64 of the Ukrainian Constitution ${ }^{24}$. The Constitutional Court also stated,

${ }^{22}$ Verkhovna Rada Ukrainy [Verhovna Rada of Ukraine]. (n.d.). rada.gov.ua. Retrived from http://w1.c1.rada.gov.ua/pls/zweb2/webproc4_1?pf3511=57463 [in Ukrainian].

${ }^{23}$ Rishennia Konstytutsiinoho Sudu Ukrainy u spravi za konstytutsiinym zvernenniam Tovarystva z obmezhenoiu vidpovidalnistiu "Torhovyi Dim "Kampus Kotton klab" [Ruling of the Constitutional Court of Ukraine]. (n.d.). zakon.rada.gov.ua. Retrived from https://zakon.rada.gov.ua/laws/show/v015p710-02 [in Ukrainian].

${ }^{24}$ Konstytutsiia Ukrainy [The Constitution of Ukraine]. (n.d.) zakon. rada.gov.ua Retrived from https://zakon.rada.gov.ua/laws/show/254к/96-вр.[in Ukrainian]. 
that in the case of obligatory pre-trial settlement of a dispute, which excludes the acceptance of a statement of claim for consideration and enforcement of justice, the right of a person for judicial protection will be violated. The possibility for persons to use pre-trial settlement of disputes might be an additional method of legal defense; the purpose of such complicated clauses is clear - to provide the parties with the opportunity to resolve their dispute without unnecessary expenses related to an arbitration hearing or to reduce and accelerate an arbitration procedure by reaching a certain compromise or even to resolve the merit of the dispute. And, also, proceeding from the need to increase the level of legal protection, the state can stimulate resolution of legal disputes within the framework of pre-trial procedures, but their use is discretionary standard rather than a binding one. The right to effective judicial protection does not deprive subjects of legal relations of the possibility of pretrial settlement of disputes. This can be provided for by a civil law contract when persons voluntarily choose means of protecting their rights. Pre-trial settlement of a dispute can also take place by the will of each of the participants in the legal relationship and even in the absence of the contract regarding such kind of settlement of the dispute.

Ergo, we can conclude, that selection of a certain legal remedy, including pre-trial settlement of a dispute in Ukraine, is a dispositive right of a person who may voluntarily, based on his own interests, use it. Legal establishment of mandatory pre-trial settlement of a dispute limits the possibility of exercising the right to judicial protection. Application for arbitration is contractual and not constitutional. Consequently, there may be restrictions stipulated by the agreement (contract of the parties) only.

Despite all the difficulties with mediation in Ukraine, one, but big and definitely positive step forward towards mediation was made not that long ago. On the $7^{\text {th }}$ of August 2019 Ukraine has signed the United Nations Convention on International Settlement Agreements Resulting from Mediation, called the Singapore Convention on Mediation. Mediation is a means of dispute resolution and an alternative to the court is only beginning to grow in Ukraine. The signing of the convention will be another impetus for the adoption of the Ukrainian national law on mediation and the improvement of the whole legal system. It will encourage the use of mediation to resolve transnational disputes in international commercial arbitration. As we know, the legal validity (force) of the agreement entered into as a result of mediation is one of the crucial factors in deciding the parties of a dispute to betake mediation.

Execution of mediation agreements with an international element makes it difficult to find parties in different jurisdictions. But, the Convention, therefore, provides for the obligation of the states parties to the Convention to enforce international mediation agreements in accordance with national 
procedural law and in accordance with the conditions laid down in the Convention. If, for example, a Ukrainian company and another foreign company from a member country of the Convention has a dispute that was settled during and by means of mediation, one will only need to go to the Court for a simplified procedure for formally reviewing and recognizing such a decision and obtaining a court order for implementation.

Hence, this Convention adds guarantees of execution of the mediation and implementation of agreements that have been concluded as a result of mediation. Ukraine's participation in the signing of the Convention gives a good sign for the world international trade business, as well as, a huge step for Ukraine in recognition of the mediation process and joining the world community. Also, for the long run, it will have the effect of creating a more favorable investment climate, reducing the costs of business to settle disputes and unloading the courts.

One more issue is extremely important. It is necessary to differentiate mediation and settlement agreements. Settlement agreements can be concluded not only in the mediation process but also in the process of other peaceful methods of dispute settlement (negotiation, reconciliation), authors of the Convention stressed in the text that the Convention will be applied only to the agreements concluded as a result of mediation.

\section{The award deals with a difference not contemplated by or not falling} within the terms of the submission to arbitration or contains decisions on matters beyond the scope of submission to arbitration, provided that, where the decisions on matters submitted to arbitration can be separated

from those not so submitted, that part of the award which contains decisions on matters submitted to arbitration may be recognized and enforced

Cargill International SA $v$ LZ Group INC case was initiated under a partnership agreement concluded between companies in 2001 in accordance with the laws of England ${ }^{25}$. In 2006, a debt repayment agreement was concluded between the same parties. It is seen from the preamble of debt repayment agreement that the parties did business on the basis of the agreement concluded in 2001, out of which the indebtedness emerged. Thus, a debt repayment agreement was derived from a partnership agreement which provided for their joint business.

${ }^{25}$ Sprava "Cargill International SA v LZ Group. Inc case no. 6-4902cr12" [Case Cargill International SA v LZ Group. Inc no. 6-4902cr12]. (n.d.). reyestr.court.gov.ua. Retrieved from http://www.reyestr.court.gov.ua/Review/23930277 [in Ukrainian]. 
The debt repayment agreement specified that any dispute arising out of an existing contract had to be transferred for final settlement to the ICAC at the UCCI. Such a dispute between the parties was considered and resolved by the ICAC at the UCCI. In July 2009, LZ Group Inc. applied to the Court for setting aside the final award. The application was based upon the allegation that the decision was made with an infraction of the law, whereunder arbitral tribunals may not consider matters beyond the scope of arbitral agreement. Ukrainian Court granted the application for setting aside the award taking into account the fact that the ICAC considered the case that was not covered by an arbitration agreement between the parties.

In the above mentioned case, we can again observe, that the Court of Ukraine does not take into account the principle of the competence of the arbitral tribunal and the principle of the waiver of the right to object that we have discussed above.

\section{The award has not yet become binding on the parties, or has been set aside or suspended by a competent authority of the country in which, or under the law of which, that award was made}

Polske hurnitstvo naftove $i$ hazovnitstvo S.A. v Devon case ${ }^{26}$. Ukrainian local Court considered the evidence that had to be provided to the Court to prove the entry into force of an arbitral award. The application from the party must be accompanied by a decision of the foreign Court and an official document to the effect that the decision has come into force and is enforceable or that it is enforceable until it is legally valid unless this is evident from the decision itself in accordance with Art. 7 of the Resolution № $12^{27}$.

The arbitration award itself stated that it was final, but it did not indicate at which moment the Court's decision would come into force, and there was no any official document mentioning that the arbitral award was legally valid. Therefore, the case was transferred for a new trial to the Court of first instance in Ukraine.

${ }^{26}$ Sprava "Polske hurnitstvo naftove i hazovnitstvo S.A. v Devon" case no. 757/1469/16-ц" [Case Polske hurnitstvo naftove i hazovnitstvo S.A. v Devon no. 757/1469/16-ц] (n.d.). reyestr.court.gov.ua. Retrieved from http://www.reyestr.court.gov.ua/Review/70845941 [in Ukrainian].

${ }^{27}$ Postanova no. 12 Plenum verkhovnoho sudu Ukrainy "Pro praktyku rozghliadu sudamy klopotan pro vyznannia y vykonannia rishen inozemnykh sudiv ta arbitrazhiv i pro skasuvannia rishen, postanovlenykh u poriadku mizhnarodnoho komertsiinoho arbitrazhu na terytorii Ukrainy" [The Resolution no. 12 of the Plenum of the Supreme Court of Ukraine "On practice of consideration by courts of motions for recognition and enforcement of foreign courts' awards and arbitral tribunals' awards and on annulment of awards rendered by international commercial arbitration courts in the territory of Ukraine"]. (n.d.) zakon.rada.gov.ua Retrived from https://zakon.rada.gov.ua/laws/show/v0012700-99 [in Ukrainian]. 
The matter of binding nature of the award was also considered in the Ukrmedpostach v Vamed Engineering GmbH \& Co KG case ${ }^{28}$. The Cassation Court, considering the motion of Ukrmedpostach for recognition and enforcement of an arbitral award took into consideration, that Vamed has filed an application for setting aside of the award. At the moment of consideration by the cassation court, Vamed had obtained a ruling for setting aside of the award, in view of which recognition and enforcement in favor of Ukrmedpostach was denied.

\section{The subject matter of the difference is not capable of settlement by arbitration under the law of that country}

The matter was considered in the Ukrmedpostach v Vamed Engineering $\mathrm{GmbH} \& \mathrm{Co} \mathrm{KG}$ case cited above. The dispute between the parties arose a state owned company Ukrmedpostach and Vamed out of a contract for purchase and installation of medical equipment. The contract provided for resolution of all disputes thereunder by the ICAC at the UCCI.

Given the poor performance of obligations under the contract Ukrmedpostach filed its claims against Vamed with the ICAC at the UCCI and obtained an award in its favor. Vamed moved to set the award aside. In its setting aside application Vamed claimed, among others, that the dispute was not capable of being settled in arbitration due to its non-arbitrable nature under the Ukrainian law, which governed the contract.

The courts considered the matter and agreed with Vamed, ruling to set aside the award. In particular, the courts considered, that contract between the parties was concluded for the purposes of public needs satisfaction. As of the date of contract conclusion public needs contracts were not arbitrable under Ukrainian and could be resolved solely in the competent domestic court. Thus, the court ruled, that the dispute between the parties could not have been subjected to arbitration and thus the award could should be set aside.

\section{Recognition or enforcement of the award would be contrary to the public policy of the respective country}

The case between JKX Oil\&Gas Plc et al v Ukraine (represented by the Ministry of Justice of Ukraine $)^{29}$. An investment dispute over the failure of the

${ }^{28}$ Sprava "Ukrmedpostach v Vamed Engineering GmbH \& Co KG case no. 6-42203св14" [Case Ukrmedpostach v Vamed Engineering GmbH \& Co KG case no. 6-42203cв14] (n.d.). reyestr.court.gov.ua. Retrieved from http://www.reyestr.court.gov.ua/Review/43475034 [in Ukrainian].

${ }^{29}$ Sprava "JKX Oil\&Gas Plc et al v Ukraine case no. 757/5777/15-ц" [Case JKX Oil\&Gas Plc et al v Ukraine case no. 757/5777/15-ц] (n.d.). reyestr.court.gov.ua. Retrieved from http://www.reyestr.court.gov.ua/Review/76596637 [in Ukrainian]. 
debtor to comply with its international legal obligations under the Energy Charter Treaty (was ratified by the Verkhovna Rada of Ukraine in 1998).

The parties appealed to the Arbitration Institute of the Chamber of Commerce of Stockholm. The arbitral tribunal made a decision whereby the state of Ukraine was ordered to refrain from imposing a rent on the Poltava Petroleum Company for the use of mineral resources, for the extraction of natural gas by at a rate higher than $28 \%$, which rate was stipulated by the Ukrainian tax code of July 31, 2014. The Ministry of Justice of Ukraine, which represents the state of Ukraine in the dispute, objected to satisfaction of Poltava Petroleum Company's claim, reasoning that the arbitral award violated public order and threatened economic interests of Ukraine.

The Supreme Court found that according to the Resolution № 12 (10), the public order means the legal order of the state, basic principles, and foundations of the existing state system (related to its independence, integrity of the territory, autonomy and inviolability, basic constitutional rights, freedoms, guarantees, etc.) ${ }^{30}$. Also, in accordance with Art. 12 (1) of the Private international law (hereinafter - "On PIL"), the law of a foreign country does not apply when its application leads to consequences that are clearly incompatible with the principles of law and public order of Ukraine ${ }^{31}$.

The Supreme Court of Ukraine reasoned its decision that the relationships arising in the field of collection of taxes and mandatory charges are regulated by the Tax Code of Ukraine. The Tax Code sets out the exhaustive list of taxes and charges that are enforceable in Ukraine, the procedure for their administration, payers of taxes and charges, their rights and duties, competence of the authorities, the powers and responsibilities of their officials in the tax control, as well as responsibility for violating tax laws. In accordance with Article 7 (3) of the Tax Code of Ukraine, any taxation issues are regulated by that Code and can not be established or changed by other laws of Ukraine, except for the laws that contain provisions to amend that code and provisions that establish liability for violation of tax legislation. Only the Tax Code of Ukraine specifies the grounds for the

${ }^{30}$ Postanova no. 12 Plenum verkhovnoho sudu Ukrainy "Pro praktyku rozghliadu sudamy klopotan pro vyznannia y vykonannia rishen inozemnykh sudiv ta arbitrazhiv i pro skasuvannia rishen, postanovlenykh u poriadku mizhnarodnoho komertsiinoho arbitrazhu na terytorii Ukrainy" [The Resolution no. 12 of the Plenum of the Supreme Court of Ukraine "On practice of consideration by courts of motions for recognition and enforcement of foreign courts' awards and arbitral tribunals' awards and on annulment of awards rendered by international commercial arbitration courts in the territory of Ukraine"]. (n.d.) zakon.rada.gov.ua Retrived from https://zakon.rada.gov.ua/laws/show/v0012700-99 [in Ukrainian].

${ }^{31}$ Zakon Ukrainy "Pro mizhnarodne pryvatne pravo" [The law of Ukraine " On Private International Law”]. (n.d). zakon.rada.gov.ua. Retrived from https://zakon.rada.gov.ua/laws/ show $/ 2709-15$ ?find $=1 \&$ text $=\% \mathrm{EF} \% \mathrm{~F} 3 \% \mathrm{E} 1 \% \mathrm{~EB} \% \mathrm{~B} 3 \% \mathrm{~F} 7 \% \mathrm{ED} \% \mathrm{E} 8 \% \mathrm{E} 9$ [in Ukrainian]. 
granting of tax privileges and the procedure for their application ${ }^{32}$. The Court ruled that the arbitral award was contrary to the requirements of the Ukrainian Tax Code and could actually change the rental fees to be paid by a legal entity Poltava Petroleum Company for the use of resources to extract natural gas from $55 \%$ to $28 \%$.

The opinion of the Supreme Court was motivated by the fact that extending the competence of arbitral Courts to change the size of taxes or mandatory charges is contrary to the rules of the tax code of Ukraine and would be a violation of the basic, determined principles of taxation established in the state and by the state and, therefore, recognition and enforcement of an arbitral award violates the public order of Ukraine, and therefore, an arbitral award can not be recognized and enforced in the territory of Ukraine.

In authors opinion, on the one hand, the definition of public order in Ukraine is generalized and rather inexact, but on the other hand, the result of enforcement of the foreign arbitration award - change of the whole Ukrainian taxation system - is very vivid and obvious. Therefore, we will get the conflict of two laws in one jurisdiction: national and foreign. Thus, the very concept of public order in Ukraine means that no foreign law can compete with the norms of the national law and the latter will always prevail.

There are a number of other grounds for canceling or refusing in recognition of arbitral awards, but they probably relate to more technical issues, for example, the case between SPACE-COMMUNICATION LTD and the TV-broadcasting company "MIST $T B$ "33. The request of SPACECOMMUNICATION LTD on recognition and enforcement of the ICAC award was not signed by the person in whose favor the decision was made and I application for recognition and enforcement shall be submitted in writing and signed by the person in whose favor the decision has been made or by its representative. Such applications submitted without compliance with the requirements remain unmoved, but the deadline for the elimination of deficiencies is mentioned in Article 185 of the CPC of Ukraine. Few more reasons, it is when an arbitration agreement does not contain the exact name of the court to which the parties must refer disputes, the case "ARSLAN" and "HUAWEI"34, or when order of enforcement issued by the state court of Ukraine does not meet the requirements of the law of Ukraine.

32 Podatkovyi kodeks Ukrainy [The Tax Code of Ukraine]. (n.d.). zakon.rada.gov.ua. Retrived from https://zakon.rada.gov.ua/laws/show/2755-17 [in Ukrainian].

33 Sprava "Space-communication LTD v. MIST TB no. 22-k/796/190/18" [Case Spacecommunication LTD v. MIST TB no. 22-k/796/190/18] (n.d.). reyestr.court.gov.ua. Retrieved from http://www.reyestr.court.gov.ua/Review/76153012 [in Ukrainian].

${ }^{34}$ Sprava “Arslan v Huawei no. 910/8259/13" [Case "Arslan v Huawei no. 910/8259/13"]. (n.d.). reyestr.court.gov.ua. Retrived from http://www.reyestr.court.gov.ua/Review/33822930 [in Ukrainian]. 
Just the same as it was in the case "Metalurhiinyi zavod Dniprostal" and "DALMOND TRADE HOUSE LTD”, because order of enforcement did not contain full information about the debtor and full-resolution part of the decision of the ICAC of Ukraine, as well as it did not specify the correct date of legal validity of the award ${ }^{35}$.

\section{CONCLUSIONS}

In solving a particular case in court, we have to consider countless nuances. Legal practice is always ambiguous, diverse and complex, irrespective of the country, but we should follow those approaches or tendencies that could bring us most fruitful and predictable results.

Each arbitration-friendly jurisdiction should strictly follow the transnational rules, conventions, and other international norms, especially when dealing with grounds for annulment of international commercial arbitration awards and, of course, take into consideration their own national laws. The balance between international and national laws is very fragile, and it is very easy to cross the borderline in using norms of the national law more than it is necessary or preferring to use the norms of the domestic law rather than settled legal doctrines, rules, concepts, principles of international commercial arbitration.

As it is seen from the cases analyzed above, grounds for setting aside arbitral awards in Ukraine are set out in provisions of the NY Convention and in very specific and peculiar national norms, such as provisions of the $\mathrm{CC}$ or the CPC of Ukraine, resolutions, special juridical acts or provisions about the public order. Even the absence of the law, (e.g. the mediation law, which existence, in my understanding, as a doctrine still must be created in Ukraine) may be the ground to set aside an arbitral award. Till that time, from one side, Ukraine has constitutional norms, which do not contain any restrictions or warnings that prohibit rendering justice before an attempt of the preliminary settlement of the dispute by the parties. From the other side, one can also understand the existence of the idea that an appeal to arbitration is a contractual right of the parties, which implies its subordination to and limitedness by the terms of the arbitration clause.

We can also distinguish three dominating approaches used by judges for the cancellation of the arbitral awards in Ukraine. Although the approaches look controversial, debatable and ambiguous, they are the parts of the legal

\footnotetext{
${ }^{35}$ Sprava "Metalurhiinyi zavod Dniprostal v Dalmond Trade House LTD no. 202/4050/16-ц" [Case "Metalurhiinyi zavod Dniprostal v Dalmond Trade House LTD no. 202/4050/16-ц"] (n.d.). reyestr.court.gov.ua.Retrived from http://www.reyestr.court.gov.ua/Review/61445459 [in Ukrainian].
} 
mechanism used for annulment of arbitration awards in Ukraine. National Ukrainian Courts generally do not fully take into consideration such legal phenomena as 1) waiver of the right to object, 2) recognition of arbitral tribunal's competence, 3) conclusion of an arbitration agreement by exchanging the statement of claim and the answer to this claim. These tendencies are dominating in the Ukrainian litigation. They make a tremendous most principal impact on setting aside the arbitral awards in Ukraine and they are shaped with the influence of the Ukrainian national laws.

The percentage of the set aside arbitration awards or refusals of their recognition and enforcement in Ukraine is rather small. Among such a small number there are cancellations which seem to be very reasonable, logical and do not raise any specific questions or objections, for example, when the party was not duly informed about arbitral hearing or when the decision of the tribunal has not yet entered into force. However, there are, also, other grounds for cancellation of the arbitral awards in Ukraine. Their legal mechanisms for cancellation are based on the national legal norms and domestic law. These grounds look rather controversial not only because they exclude some arbitration very basic concepts, but also referring to the one norm of the Ukrainian law while cancelling the award, the judge does not take into consideration the fact that this norm is contrary to the other norm of the Ukrainian law while both these norms (laws) have equal legal power. Moreover, if such contradictions are accompanied by the lack of the clarity, for instance, in the definition of the public order or by the absence of the law such as mediation, thus, we will get the result absolutely incompatible with the idea of predictable legal practice.

The way out of this situation is quite easy and possible. From my perspective, judges should follow and take into consideration the norms of international law, international commercial arbitration case law, legal doctrines, and principles, rather than only national Ukrainian laws, even if the parties have chosen the Ukrainian law to be applied to the merit of the dispute. And, of course, judges dealing with the cases for annulment of arbitral awards in local Ukrainian courts must have a degree in international law and must know at least one world language, preferably English at a very high level.

The consequences of reference to and application of the national laws when cancelling arbitration awards, without taking into account transnational concepts, doctrines and the world arbitration principles and practice can result in ambiguity and, hence, can lead to unpredictable, untrustworthy and unclear practice. The latter, in its turn, will lead to loss of interest in cooperation with this jurisdiction, as well as in worsening of commercial relations.

Court practice is proven to be the key source in interpreting the current legislation. Overall analysis suggests that each of the potential obstacles in 
arbitration proceedings could be overcome given an understanding of how the mechanism of juridical logic is functioning in a state, hence, ensuring that the proceedings and, which is the most important result of it, enforcement of the arbitral award would be easy, efficient and successful.

I kept one more idea for last. The Ukrainian legal practice shows that cancellation of the arbitral awards is considered by civilian judges. It means that judges with specialization in Ukrainian domestic law must consider cases connected with private international law and transnational norms. Hence, in my belief, national judges as a minimum should know the English language and the International Commercial Arbitration case law and follow its development. But, the absence of the mediation law made workload per judge extremely heavy, as well as the existence of the language barrier, prevent them from mastering it to the required level. We can assume that the Ukrainian jurisdiction is not the only one to face these issues. A large number of other states might have the same problems as well. Thus, the best way out for Ukraine in this situation, as far as the author sees it, is to have high-skilled judges with a degree in international law and knowledge of at least one foreign world language. In this case, judges in local Ukrainian Courts will be able to deal with such category of cases more predictably and to solve them according to the world tendencies in international arbitration.

\section{SUMMARY}

This article deals with issues that are closely related to the interpretation and practical application of transnational legal norms and national legal acts in the cancellation of arbitral awards in the Ukrainian jurisdiction. Legal analysis of reasons for the cancellation of arbitral awards, as well as for the refusal to recognize and enforce them, is based on the Ukrainian legal practice and can be of considerable interest to practicing lawyers, judges, advocates, and students. This research into the Ukrainian legal practice enables us to understand the specificities of the national legislation and the extent of its consistency with theoretical and practical doctrines in the world's international arbitration. It also makes it possible to make conclusions about current tendencies (approaches) in the settled legal practice.

Over recent years, Ukraine has proven to be an arbitration-friendly jurisdiction, but still, there are cases of setting aside arbitration awards and refusing to recognize and enforce them. The idea of this article is to use examples from legal practice to reveal current peculiarities of the Ukrainian legal system, approaches to, reasoning, grounds and consequences for setting aside of arbitral awards in Ukraine; to show mechanisms of work, structure and argumentation of juridical logic behind cancelling or refusing to enforce arbitral awards in Ukraine. 


\section{REFERENCES}

1. Sait of electronic encyclopedia "The new Encyclopedia Britannica" [Sait of encyclopedia "The new Encyclopedia Britannica"]. britannica.com. Retrieved from https://www.britannica.com/topic/arbitration [in English].

2. Convention "On the Recognition and Enforcement of Foreign Arbitral Awards" [Convention "On the Recognition and Enforcement of Foreign Arbitral Awards"] (n.d.) newyorkconvention.org. Retrieved from http://www.newyorkconvention.org/list+of+contracting+states [in English].

3. Convention on the Recognition and Enforcement of Foreign Arbitral Awards, June 10, 1958. Available at: http://www.newyorkconvention.org/ list+of+contracting+states

4. Tsyvilnyi protsesualnyi kodeks Ukrainy [Ukrainian Code of Civil Procedure] (n.d.) kodeksy.com.ua. Retrieved from https://kodeksy.com.ua/ tsivil_nij_protsesual_nij_kodeks_ukraini/459.htm [in Ukrainian].

5. Zakon Ukrainy "Pro mizhnarodnyi komertsiinyi arbitrazh" [The Law of Ukraine "On International Commercial Arbitration"]. (n.d.) zakon.rada.gov.ua Retrived from https://zakon.rada.gov.ua/laws/show/400212 [in Ukrainian].

6. Sprava "LG Electronics Ukraine v Ant Yapi Sanayi Ve Ticaret Anonim Shirketi No. 761/605/17-ц" [Case LG Electronic Ukraine v Ant Yapi Sanayi Ve Ticaret Anonim Shirketi № 761/605/17-ц]. (n.d.). reyestr.court.gov.ua. Retrieved from http://www.reyestr.court.gov.ua/Review/ 70416292 [in Ukrainian].

7. Tsyvilnyi kodeks Ukrainy [The Civil Code of Ukraine]. (n.d.). zakon.rada.gov.ua. Retrived from https://zakon.rada.gov.ua/laws/show/43515 [in Ukrainian].

8. Postanova No. 12 Plenum verkhovnoho sudu Ukrainy "Pro praktyku rozghliadu sudamy klopotan pro vyznannia y vykonannia rishen inozemnykh sudiv ta arbitrazhiv i pro skasuvannia rishen, postanovlenykh u poriadku mizhnarodnoho komertsiinoho arbitrazhu na terytorii Ukrainy" [The Resolution No. 12 of the Plenum of the Supreme Court of Ukraine "On practice of consideration by courts of motions for recognition and enforcement of foreign courts' awards and arbitral tribunals' awards and on annulment of awards rendered by international commercial arbitration courts in the territory of Ukraine"]. (n.d.) zakon.rada.gov.ua Retrived from https://zakon.rada.gov.ua/laws/show/v0012700-99 [in Ukrainian].

9. Tsyvilnyi kodeks Ukrainy [The Civil Code of Ukraine]. (n.d.) zakon.rada.gov.иа Retrived from https://zakon1.rada.gov.ua/laws/show/43515/ed20120618 [in Ukrainian].

10. Zakon Ukrainy "Pro mizhnarodnyi komertsiinyi arbitrazh" [The Law of Ukraine "On International Commercial Arbitration"]. (n.d.) zakon.rada.gov.ua Retrived from https://zakon.rada.gov.ua/laws/show/400212 [in Ukrainian]. 
11. Phillip Landolt, The Inconvenience of Principle: Separability and Kompetenz-Kompetenz (2013) [The Inconvenience of Principle: Separability and Kompetez-Kompetenz] Journal of International Arbitration, (Vols 30), (pp. 511-530). The Netherlands: Kluwer Law International BV [in English].

12. Ronán Feehily, (2018). Separability in international commercial arbitration; confluence, conflict and the appropriate limitations in the development and application of the doctrine [Separability in international commercial arbitration; confluence, conflict and the appropriate limitations in the development and application of the doctrine] Arbitration International, 34. Retrived from https://academic.oup.com/arbitration/article-abstract/34/3/355/ 5098414 [in English].

13. The UNCITRAL Model Law [The UNCITRAL Model Law]. (n.d.) uncitral.un.org. Retrived from https://uncitral.un.org/en/texts/arbitration/ modellaw/commercial_arbitration [in English].

14. Sprava "Naumann Machyny i Pallety v Bruma № No. 159/4966/15-ц" [Case Naumann Machyny i Pallety v Bruma № o. 159/4966/15-ц] (n.d.). reyestr.court.gov.ua. Retrieved from http://www.reyestr.court.gov.ua/Review/ 63323683 [in Ukrainian].

15. Sprava "Sea Emerald S.A. v Sudnobudivny zavod imeni 61 comunara case No. 1423/15646/2012" [Case Sea Emerald S.A. v Sudnobudivny zavod imeni 61 comunara No. 1423/15646/2012]. (n.d.). reyestr.court.gov.ua. Retrieved from http://www.reyestr.court.gov.ua/Review/62203095 [in Ukrainian].

16. The Arbitration Act 1996 [The Arbitration Act 1996]. (n.d.). legislation.gov.uk. Retrived from https://www.legislation.gov.uk/ukpga/ 1996/23/section/76 [in English].

17. Sprava Nussed Serbia d.o.o. v Rise Company case No. 761/5425/16-ц [Case Nussed Serbia d.o.o. v Rise Company case No. 761/5425/16-ц]. (n.d.). reyestr.court.gov.ua. Retrieved from http://www.reyestr.court.gov.ua/Review/ 71534619 [in Ukrainian].

18. The ICAC at the UCCI Rules 2018 [The ICAC at the UCCI Rules 2018]. (n.d.). icac.org.ua Retrived from https://icac.org.ua/en/arbitrazh/ reglament/ [in English].

19. Reinhold, Steven, Good Faith in International Law (2013). [Good Faith in International Law] Journal of Law and Jurisprudence, 2. Retrived from https://ssrn.com/abstract=2269746 [in English].

20. Analytical Commentary on Draft Text of a Model Law on International Commercial Arbitration A/CN.9/264 [Analytical Commentary on Draft Text of a Model Law on International Commercial Arbitration A/CN.9/264]. (n.d.). mcgill.ca Retrived from https://www.mcgill.ca/arbitration/files/arbitration/ Commentaireanalytique-en.pdf [in English]. 
21. Sprava SES Astra AB v Ukrkosmos No. 757/34281/14-ц [Case SES Astra AB v Ukrkosmos No. 757/34281/14-ц] (n.d.). reyestr.court.gov.ua. Retrived from http://www.reyestr.court.gov.ua/Review/62960687 [in Ukrainian].

22. Sprava "Odessa Sea Commercial Port v International Port Services Ltd case No. 6-18634св07" [Case Odessa Sea Commercial Port v International Port Services Ltd case No. 6-18634св07]. (n.d.). reyestr.court.gov.ua. Retrieved from http://www.reyestr.court.gov.ua/Review/1603221 [in Ukrainian].

23. Verkhovna Rada Ukrainy [Verhovna Rada of Ukraine]. (n.d.). rada.gov.ua. Retrived from http://w1.c1.rada.gov.ua/pls/zweb2/webproc4_ 1?pf3511=57463 [in Ukrainian].

24. Rishennia Konstytutsiinoho Sudu Ukrainy u spravi za konstytutsiinym zvernenniam Tovarystva z obmezhenoiu vidpovidalnistiu "Torhovyi Dim "Kampus Kotton klab" [Ruling of the Constitutional Court of Ukraine]. (n.d.). zakon.rada.gov.ua. Retrived from https://zakon.rada.gov.ua/laws/show/ v015p710-02 [in Ukrainian].

25. Konstytutsiia Ukrainy [The Constitution of Ukraine]. (n.d.) zakon. rada.gov.ua Retrived from https://zakon.rada.gov.ua/laws/show/254K/96вр.[in Ukrainian].

26. Sprava "Cargill International SA v LZ Group. Inc case No. 6-4902cr12" [Case Cargill International SA v LZ Group. Inc No. 6-4902cr12]. (n.d.). reyestr.court.gov.ua. Retrieved from http://www.reyestr.court.gov.ua/ Review/23930277 [in Ukrainian].

27. Sprava "Polske hurnitstvo naftove i hazovnitstvo S.A. v Devon" case No. 757/1469/16-ц [Case Polske hurnitstvo naftove i hazovnitstvo S.A. v Devon No. 757/1469/16-ц] (n.d.). reyestr.court.gov.ua. Retrieved from http://www.reyestr.court.gov.ua/Review/70845941 [in Ukrainian].

28. Postanova No. 12 Plenum verkhovnoho sudu Ukrainy "Pro praktyku rozghliadu sudamy klopotan pro vyznannia y vykonannia rishen inozemnykh sudiv ta arbitrazhiv i pro skasuvannia rishen, postanovlenykh u poriadku mizhnarodnoho komertsiinoho arbitrazhu na terytorii Ukrainy" [The Resolution No. 12 of the Plenum of the Supreme Court of Ukraine "On practice of consideration by courts of motions for recognition and enforcement of foreign courts' awards and arbitral tribunals' awards and on annulment of awards rendered by international commercial arbitration courts in the territory of Ukraine"]. (n.d.) zakon.rada.gov.ua Retrived from https://zakon.rada.gov.ua/laws/show/v0012700-99 [in Ukrainian].

29. Sprava "Ukrmedpostach v Vamed Engineering GmbH \& Co KG case No. 6-42203 св14" [Case Ukrmedpostach v Vamed Engineering GmbH \& Co KG case No. 6-42203св14] (n.d.). reyestr.court.gov.ua. Retrieved from http://www.reyestr.court.gov.ua/Review/43475034 [in Ukrainian]. 
30. Sprava "JKX Oil\&Gas Plc et al v Ukraine case No. 757/5777/15-ц" [Case JKX Oil\&Gas Plc et al v Ukraine case No. 757/5777/15-ц] (n.d.). reyestr.court.gov.ua. Retrieved from http://www.reyestr.court.gov.ua/Review/ 76596637 [in Ukrainian].

31. Postanova No. 12 Plenum verkhovnoho sudu Ukrainy "Pro praktyku rozghliadu sudamy klopotan pro vyznannia y vykonannia rishen inozemnykh sudiv ta arbitrazhiv i pro skasuvannia rishen, postanovlenykh u poriadku mizhnarodnoho komertsiinoho arbitrazhu na terytorii Ukrainy" [The Resolution No. 12 of the Plenum of the Supreme Court of Ukraine "On practice of consideration by courts of motions for recognition and enforcement of foreign courts' awards and arbitral tribunals' awards and on annulment of awards rendered by international commercial arbitration courts in the territory of Ukraine"]. (n.d.) zakon.rada.gov.ua Retrived from https://zakon.rada.gov.ua/laws/show/v0012700-99 [in Ukrainian].

32.Zakon Ukrainy "Pro mizhnarodne pryvatne pravo" [The law of Ukraine " On Private International Law"]. (n.d). zakon.rada.gov.ua. Retrived from https://zakon.rada.gov.ua/laws/show/2709-15?find=1\&text=\%EF\%F3\% E1\%EB\%B3\%F7\%ED\%E8\%E9 [in Ukrainian].

33. Podatkovyi kodeks Ukrainy [The Tax Code of Ukraine]. (n.d.). zakon.rada.gov.ua. Retrived from https://zakon.rada.gov.ua/laws/show/ 2755-17 [in Ukrainian].

34. Sprava "Space-communication LTD v. MIST TB No. 22-k/796/190/18" [Case Space-communication LTD v. MIST TB No. 22-k/796/190/18] (n.d.). reyestr.court.gov.ua. Retrieved from http://www.reyestr.court.gov.ua/Review/ 76153012 [in Ukrainian].

35. Sprava "Arslan v Huawei No. 910/8259/13", [Case "Arslan v Huawei No. 910/8259/13”]. (n.d.). reyestr.court.gov.ua. Retrived from http://www.reyestr.court.gov.ua/Review/33822930 [in Ukrainian].

36. Sprava "Metalurhiinyi zavod Dniprostal v Dalmond Trade House LTD No. 202/4050/16-ц" [Case "Metalurhiinyi zavod Dniprostal v Dalmond Trade House LTD No. 202/4050/16-ц"] (n.d.). reyestr.court.gov.ua.Retrived from http://www.reyestr.court.gov.ua/Review/61445459 [in Ukrainian].

\section{Information about the author: \\ Yuliya Kabrera,}

Postgraduate Student,

Institute of Law, Economics and International Relations, International Humanitarian University in Odessa

33, Fountain Road str., Odessa, Ukraine ORCID ID: orcid.org/0000-0002-7357-1491 


\section{SYSTEM OF CONTRACTS FOR THE DISPOSAL OF INTELLECTUAL PROPERTY RIGHTS}

\section{Svitlana Mazurenko}

\section{INTRODUCTION}

One of the important issues in the study of intellectual property rights is the determination of the principles of regulation of relations with the disposal of economic rights to intellectual property.

Legislative provisions on the disposal of economic rights to intellectual property are regulated in the Central Committee of Ukraine, Civil Code of Ukraine and in special legislative acts. In the Civil Code of Ukraine, the regulation of contractual relations on the objects of intellectual property is devoted to Chapter 75 "Disposal of intellectual property rights" book 5 "Obligatory law". Chapter 16 of the Civil Code of Ukraine "Use of Intellectual Property Rights in Economic Activity" defines the principles of the use of intellectual property rights objects in economic relations. At the level of individual laws on the regulation of relations within individual intellectual property institutions, the provisions of the Laws of Ukraine "On Copyright and Related Rights" (Articles 31, 32), "On Protection of Rights to Inventions and Utility Models" (Art. 28), "On protection of rights to industrial designs", "On protection of rights to marks for goods and services" (Article 16), etc.

Intellectual property rights management contracts are a group of intellectual property agreements aimed at acquiring, changing or terminating economic rights for intellectual property objects ${ }^{1}$. The system of agreements on the creation of intellectual property results and the disposal of economic rights can be defined as the unity of an orderly set of civil legal agreements, which has as its systemic sign the purpose - the use of intellectual property rights and equivalents of individualization ${ }^{2}$. According to Art. 1107 of the

1 Iakubivskyi I. (2007) Dohovory shchodo rozporiadzhannia mainovymy pravamy intelektualnoi vlasnosti za zakonodavstvom Ukrainy [Agreements on the disposal of intellectual property rights under the legislation of Ukraine]. Pidpryiemnytstvo, hospodarstvo ta pravo, № 8, S. 16. [in Ukrainian].; Kryzhna V. (2004) Zahalna kharakterystyka dohovoriv shchodo rozporiadzhennia mainovymy pravamy intelektualnoi vlasnosti [General characteristics of the agreements on the disposal of intellectual property rights]. Pravo Ukrainy, № 9, S. 68. [in Ukrainian].

${ }^{2}$ Ruzakova O. (2008) Problemy postroeniya sistemy dogovorov o sozdanii rezultatov intellektualnoj deyatelnosti i rasporyazhenii isklyuchitelnymi pravami [Challenges in constructing the system of agreements on the creation of intellectual deliverables and exclusive rights]. YS. Avtorskoe pravo y smezhnye prava, № 6, S. 26. [in Russian]. 
Civil Code of Ukraine the disposal of intellectual property rights may be exercised on the basis of the following agreements: a license for the use of the object of intellectual property rights; license agreement; contract for the creation of a custom and use of the intellectual property object; an agreement on the transfer of exclusive intellectual property rights; another contract for the disposal of intellectual property rights.

The most common classification of intellectual property contracts by type of intellectual property is: copyright contracts; agreements on the use of related rights; patent-license agreements for objects of patent law; agreements on the use of the rights to the means of individualization of the participants of civil turnover, goods and services; agreements on the use of rights to the topology of integrated circuits; breeding rights agreements etc. Intellectual property rights management contracts are usually bilateral, consensual and repayable.

The essential terms of the contract for the disposal of intellectual property rights are:

- the subject matter of the contract (the object of intellectual property rights, the rights of use of which are transferred under the contract; the specific rights that are transferred; the ways of using the object, etc.);

- price (fee for the use of the intellectual property right object, which can be determined in the form of a flat-rate payment, initial (advance) payment, royalties, deductions from the proceeds received by the user; mutual charges on the wholesale price of the goods sold by the right holder and the user; advertising and promotion of goods and services in the relevant market; remuneration for specific services of the right holder, etc.);

- term (during which the contract, which does not exceed the term of the economic rights transferred under the contract), is valid.

The parties to the contract can be both natural persons who have reached the age of 14 (part 1 of Article 32 of the Civil Code of Ukraine), and legal entities (regardless of ownership and location). It should be noted that specific contractual arrangements impose special requirements on the status of the parties, such as: a commercial concession agreement requires that the parties be entities.

The form of contracts for the disposal of intellectual property rights is written. In the case of non-compliance with the written form, these contracts are void. However, the law may stipulate cases in which contracts for the disposal of intellectual property rights may be concluded verbally (Part 2 of Article 1107 of the Civil Code of Ukraine).

Contracts on the disposal of intellectual property rights are not subject to mandatory state registration, although they may be executed at the request of one of the parties in the manner prescribed by law. The absence of state 
registration does not affect the validity of the rights granted by a license or other contract and other rights to the relevant object of intellectual property rights, in particular the right to go to court for the protection of their rights (Part 1 of Article 1114 of the Civil Code of Ukraine).

The exception to this general rule applies to the contract for the transfer of exclusive intellectual property rights for the invention, utility model, industrial design, trademark, integrated circuit layout, plant variety or animal breed. In this case, the contract is valid only from the moment of its state registration in the State Intellectual Property Service of Ukraine. This conclusion follows from Part 2 of Art. 1114 of the Civil Code of Ukraine, according to which the fact of transfer of exclusive property rights of intellectual property, which in accordance with the Civil Code of Ukraine or other law are effective after their state registration, is subject to state registration ${ }^{3}$.

The direct procedure for the state registration of agreements on the disposal of intellectual property rights and other legal actions of state bodies for the implementation of the rules of law is governed by the Cabinet of Ministers of Ukraine Resolution "On Approval of the Procedure of Payment of Fees for Actions Related to the Protection of Intellectual Property Rights", "On State Registration of Copyright and Contracts Concerning the Author's Right to Work", "On Approval of the Procedure for Granting the Permission to You by the Cabinet of Ministers of Ukraine use of a patented invention (utility model) or registered topography of an integrated circuit "and acts of the Ministry of Education and Science of Ukraine adopted in due course. The latter include orders from the Ministry of Education and Science of Ukraine "On approval of the Instruction on the submission, review, publication and entry in the register of transfer of ownership of the invention (utility model) and the issue of a license to use the invention (utility model)"; "On approval of the Instruction on the submission, review, publication and entry in the register of information on the transfer of ownership of an industrial design and the issue of a license for the use of an industrial design"; "On approval of the Instruction on the submission, review, publication and entry in the register of information on the transfer of ownership of a mark for goods and services and the issue of a license to use the mark for goods and services"; "Approval of the Instruction on the Official Publication of a Statement of Readiness to Grant to Any Person the Permission to Use the Patented Invention (Utility Model) and Request for its Revocation", etc.

3 Kryzhna V. (2004) Zahalna kharakterystyka dohovoriv shchodo rozporiadzhennia mainovymy pravamy intelektualnoi vlasnosti [General characteristics of the agreements on the disposal of intellectual property rights]. Pravo Ukrainy, № 9, S. 68. [in Ukrainian]. 


\section{Licenses and License agreement}

Characterizing individual contractual structures in the field of intellectual property rights, we pay attention to licenses and license agreement.

Based on the content of Art. 1108 of the Civil Code of Ukraine can give the following definition of licenses in the field of intellectual property. A license is a written authorization granted by a person who has the exclusive right to authorize the use of an intellectual property object (licensor) to another person (licensee) for the use of that object in a particular limited area.

In general, the term "license" (from Latin licitus - authorization, law) is quite widely used in modern legislative terminology. In the context of intellectual property laws, licenses have traditionally been considered as a permit to use an intellectual property object. Thus, according to Art. 1 of the Law of Ukraine "On Protection of Rights to Inventions and Utility Models" license - permission of the patent owner (licensor) granted to another person (licensee) to use the invention (utility model) under certain conditions ${ }^{4}$.

With regard to license types, it should be noted that there are several criteria for classifying license types.

The criteria for classification are the licensee's right to grant licenses to others and the licensee's right to protect their exclusive rights against the unlawful acts of others.

In the former case, it is a simple (non-exclusive) license under which the licensee may grant the right to use the result of intellectual activity or the means of individualization to others. Licenses issued by a licensor to others must only provide for such use as is specified in the license agreement.

In the second case, it is an exclusive license under which the licensee is forbidden to issue licenses for the use of the result of intellectual activity or means of individualization to other persons. The essence of an exclusive license is the ability to use the facility in the absence of competitors. The right to prohibit all other persons from using the object still belongs to the right holder of the exclusive rights ${ }^{5}$.

Chapter 75 of the CC introduces the concept of a single license, which recognizes a license issued to one licensee and excludes the licensor from granting licenses to other persons for the use of the intellectual property right

4 Iakubivskyi I. (2007) Dohovory shchodo rozporiadzhannia mainovymy pravamy intelektualnoi vlasnosti za zakonodavstvom Ukrainy [Agreements on the disposal of intellectual property rights under the legislation of Ukraine]. Pidpryiemnytstvo, hospodarstvo ta pravo, № 8, S. 16. [in Ukrainian].

5 Naumova E. (2008) Dogovornoe regulirovanie oborota prav na intellektualnuyu sobstvennost [Contractual regulation of the circulation of intellectual property rights]. Yntellektualnaia sobstvennost. Avtorskoe pravo y smezhnye prava, № 6, S. 70-71. [in Russian]. 
in the field, which is limited by this license, but does not exclude the licensee's use of this license ect in the said field ${ }^{6}$.

The second classification of license agreements can be made depending on the will of the holder of exclusive rights to transfer the right to use the object of intellectual activity ${ }^{7}$.

First, it is a "voluntary license" under which the intellectual property right holder - the licensor voluntarily grants or undertakes to grant the other party the licensee the right to use the intellectual property object.

Second, it is a compulsory license where, at the request of the person concerned, the court, in the cases specified by law, may decide to grant that person the right to use the result of intellectual activity under certain conditions, that is, against the will of the owner of intellectual property rights ${ }^{8}$.

The third classification is in accordance with the method of protection of the object of the license agreement. License agreements are divided into: patent; patent-free; complex.

Patent license agreements are contracts for the use of intellectual property that are protected by appropriate security documents: patents or certificates.

Patent-free licenses include licensing agreements that grant the right to use scientific and technical achievements that do not have legal protection, production experience, confidential information of a managerial, commercial, organizational nature, ie production secrets ("know-how") and decisions on which applications for legal protection were filed ${ }^{9}$.

A special variety of patent and non-patent licenses should include license exchange agreements. This type of "cross-license" ("cross-license") is widespread in practice for a variety of reasons. On the one hand, later patents are often dependent on previously issued ones and cannot be used without the acquisition of a patent protected prototype. In its turn, the owner of this prototype is interested in purchasing more advanced technical solutions. As a result, licenses are exchanged between owners of related patents. On the other hand, competing firms that are interested in improving the technical and

${ }^{6}$ Kuvyrkova A.Yu. (2009) Licenzionnyj dogovor o predostavlenii prava ispolzovaniya obekta intellektualnyh smezhnyh prav [License agreement on granting the right to use the object of intellectual related rights]. Zakonodatelstvo, № 5, S. 58. [in Russian].

${ }^{7}$ Melnyk O. (2003) Dohovory u sferi intelektualnoi vlasnosti za novym Tsyvilnym kodeksom Ukrainy [Intellectual property contracts under the new Civil Code of Ukraine]. Pidpryiemnytstvo, hospodarstvo ta pravo, № 9, S. 8. [in Ukrainian].

8 Naumova E. (2008) Dogovornoe regulirovanie oborota prav na intellektualnuyu sobstvennost [Contractual regulation of the circulation of intellectual property rights]. Yntellektualnaia sobstvennost. Avtorskoe pravo y smezhnye prava, № 6, S. 70-71. [in Russian].

${ }^{9}$ Dobrynina H. (2007) Litsenziina diialnist shchodo obiektiv prava intelektualnoi vlasnosti [Licensing activity towards intellectual property objects]. Spravochnik ekonomista, № 3. S. 5. [in Ukrainian]. 
economic level of their products are more likely to use licenses than sell them without sharing any secrets ${ }^{10}$.

Under a comprehensive license agreement, a licensee obtains the right to use several intellectual property objects, some of which have legal protection and the other does not.

Depending on the object, the following license agreements are distinguished: copyright; about the grant of related rights; granting an invention, utility model or industrial design right; on the granting of trademark rights; on granting rights to the topology of integrated circuits; about granting breeding achievement rights ${ }^{11}$.

As a kind of license agreements can be considered sub-license agreement, the provisions of which are contained in part 2 of Art. 1109 of the Central Committee of Ukraine. Under this agreement, the licensee grants permission to use the intellectual property object to another person (sub-licensee). Sublicense agreement is possible only in cases, which are expressly stipulated in the license agreement between the licensee and the licensee. However, since the sublicensee is not in direct contractual relationship with the licensee, the licensee is liable to the licensee for the actions of the sublicensee, unless otherwise stipulated by the license agreement.

The Central Committee of Ukraine permits the possibility of issuing a license without concluding a license agreement. In Art. 1107 license and license agreement are defined as separate types of contracts for the disposal of intellectual property rights. However, the license itself is a one-sided transaction and cannot be regarded as a type of contract ${ }^{12}$.

Therefore, it is inappropriate to include it alongside a license agreement as a type of intellectual property rights management agreement. Assignment of a license to agreements on the disposal of intellectual property rights in Art. 1107 of the Central Committee of Ukraine is wrong ${ }^{13}$.

10 Levchenko D. (2006) Aspekty licenzionnyh dogovorov. Otnositelno licenzionnyh dogovorov o peredache prav na obekty intellektualnoj sobstvennosti [Aspects of license agreements. On license agreements on the assignment of intellectual property rights]. Yurydycheskaia praktyka, № 11, S. 22. [in Russian].

${ }_{11}$ Ruzakova O. (2008) Problemy postroeniya sistemy dogovorov o sozdanii rezultatov intellektualnoj deyatelnosti i rasporyazhenii isklyuchitelnymi pravami [Challenges in constructing the system of agreements on the creation of intellectual deliverables and exclusive rights]. YS. Avtorskoe pravo y smezhnye prava, № 6, S. 26. [in Russian].

12 Kryzhna V. (2004) Zahalna kharakterystyka dohovoriv shchodo rozporiadzhennia mainovymy pravamy intelektualnoi vlasnosti [General characteristics of the agreements on the disposal of intellectual property rights]. Pravo Ukrainy, № 9, S. 68. [in Ukrainian].

13 Iakubivskyi I. (2007) Dohovory shchodo rozporiadzhannia mainovymy pravamy intelektualnoi vlasnosti za zakonodavstvom Ukrainy [Agreements on the disposal of intellectual property rights under the legislation of Ukraine]. Pidpryiemnytstvo, hospodarstvo ta pravo, № 8, S. 16. [in Ukrainian]. 
Special laws, unlike the Central Committee of Ukraine (for example, Article 32 of the Law of Ukraine "On Copyright and Related Rights", Article 28 of the Law of Ukraine "On Protection of Rights to Inventions and Utility Models" Article 20 of the Law of Ukraine "On Protection of Rights to industrial designs", Article 16 of the Law of Ukraine" On Protection of Rights to Marks for Goods and Services", Article 40 of the Law of Ukraine" On Protection of Rights to Varieties of Plants", Article 16 of the Law of Ukraine" On Protection of Rights for Topographies integrated circuits") proceed from the fact that a license is always issued on the basis of a license agreement. Apparently, this approach is more grounded and correct. It is difficult to imagine the option of granting an entity that owns intellectual property rights a license to use the object without entering into a contract. It is the license agreement in this case that is the basis for granting the permit (issuing a license) and, at the same time, a means of determining the conditions for granting such a license.

Referring to the characteristics of the license agreement, it should be noted that it occupies an important place among the agreements on the disposal of intellectual property rights. According to Art. 1109 of the Civil Code of Ukraine under a license agreement one party (the licensee) grants the other party (the licensee) permission to use the object of intellectual property (license) on terms determined by mutual agreement of the parties, taking into account the requirements of the Central Committee of Ukraine and other law.

In the scientific literature, the following specific features of the license agreement are distinguished: the intellectual product offered for transfer under the contract is intangible; the licensee acquires the right to use the intellectual property rights defined in the contract by the contract; tangible objects, if transferred under a license agreement, are only carriers of information that is the object of intellectual property; the core element of the license object - the exclusive intellectual property right does not pass to the licensee, but is only granted a temporary right to use the object of that right; the patent holder retains proprietary rights to the intellectual property when granting the license ${ }^{14}$.

A license agreement is considered to have been concluded if the parties have agreed to the essential terms (ie, those conditions which are recognized as essential by law or necessary for contracts of this type), ie such agreement is legally consensual ${ }^{15}$. In addition, a mandatory condition for the validity of a

14 Bazylevych V.D. (2008) Intelektualna vlasnist: pidruchnyk [Intellectual property: a textbook]. K. : Znannia, S. 221. [in Ukrainian]

${ }^{15}$ Kyryliuk A.V. (2008) Litsenziinyi dohovir na vykorystannia literaturnykh tvoriv: poniattia, umovy, forma [License agreements on the use of literary writings: concept, conditions, form]. Aktualni problemy derzhavy i prava, № 41, S. 192. [in Ukrainian]. 
license agreement is to conclude it in writing, since failure to comply with the written form results in the nullity of such agreement (Part 2 of Article 1107 of the Civil Code of Ukraine). Please note that the license agreement may not be the right to use an intellectual property object that was not valid at the time the contract was concluded.

Based on the provisions of Part 1 of Art. 638 and Part 3 of Art. 1109 of the Civil Code of Ukraine to the essential terms of the license agreement belong to the subject of the contract; type of license; scope of the intellectual property right object (specific rights conferred by the contract, ways of using the said object, territory and terms to which the rights are granted, etc.), size, procedure and payment terms for the use of the intellectual property right object property.

The parties to the license agreement must clearly identify the possible extent of the use of the intellectual property object, the possibility of transferring the intellectual property object to third parties, maintaining the confidentiality of the content of the license agreement, the procedure and amount of payment.

It should be noted that the Central Committee of Ukraine has expanded the scope of the license agreement. If in the special legislation on intellectual property the copyright contract in the field of copyright and the license agreement in the field of industrial property differ, then the Central Committee of Ukraine establishes a universal design of the license agreement, which applies to both the objects of copyright and the objects of industrial property.

The primary legal purpose of this agreement is to grant a license (license) for the use of a specific intellectual property right. The license agreement is one of the options for obtaining a license for the use of intellectual property rights (Part 2 of Article 1108 of the Civil Code of Ukraine). Therefore, the provisions of Art. 1108 of the Civil Code of Ukraine on licenses for the use of intellectual property rights should also be applied to the license agreements ${ }^{16}$.

Typical contracts have traditionally played an important role in the legal regulation of contractual relations in the field of intellectual property. In the Central Committee of Ukraine the provisions on standard license agreements are contained in Art. 1111. The Institute for Standard License Agreements is intended to provide enhanced protection of the interests of the creator of the intellectual property object in the contractual relationship. The right to approve standard license agreements in accordance with Part 1 of Art. 1111 of

16 Kossak V.M., Yakubivskyi I.Ie. (2007) Pravo intelektualnoi vlasnosti: pidruchnyk [Intellectual property law: a textbook]. K. : Istyna, S. 158-159. [in Ukrainian] 
the Central Committee of Ukraine was provided to authorized agencies and creative unions.

The license agreement may, in the cases provided for by law, entail the conclusion of a sub-license agreement whereby the licensee grants a sublicense to another (sub-licensee) for the use of the intellectual property object. In this case, the licensee shall be liable to the licensee for the actions of the sub-licensee, unless otherwise stipulated by the license agreement.

\section{The contract on the creation and use of the intellectual property object}

The contract on the creation and use of the intellectual property object plays a special role in the mechanism of civil law regulation of copyright, creating the preconditions for their dynamics. Relationships for the creation of a copyright object can be described as organizational relations, namely preordering, since the contractual contractual relations of the copyright order are the legal connection of the parties that arises before the creation of the copyright object. Assuming that copyright regulates relationships that arise in the process of using a work already created, then before the creation of the work itself, the party to the copyright contract can only be called by the author provisionally, correctly call her the person who is obliged to create the work ${ }^{17}$.

The essential terms of the contract are: the subject of the contract, the term of creation of the object of intellectual property rights, methods and conditions of its use, the price.

When considering the content of the copyright contract, it is proposed to split it into two parts. The first part of the contract consists of the conditions aimed at regulating the relations that arise from the author's creation of his work. The second part of the conditions consists of the conditions inherent in the copyright agreement under which the finished work is transmitted ${ }^{18}$.

The first part of the contract includes the terms of the subject of the contract and its description, the rights and obligations of the parties, the goods of the contract, responsibility for breach of contract.

Attention should be paid to the specifics of the copyright contract. It is concluded at a time when the intellectual property object does not yet exist, and due consideration should be given to the characterization of the subject matter of this agreement and the definition of its features. As a rule, objects of copyright and related rights are the subject of the contract because the creation

${ }^{17}$ Sorokyna L.V. (2008) Otgranichenie avtorskogo dogovora zakaza ot smezhnyh dogovorov [Delimitation of commissioning agreement from related agreements]. Rossyiskyi yurydycheskyi zhurnal, № 5, S. 204. [in Russian].

${ }^{18}$ Zavalna Zh. (2002) Osoblyvosti dohovoru zamovlennia v avtorskomu pravi [Special aspects of an ordering agreement in copyright law]. Pidpryiemnytstvo, hospodarstvo i pravo, № 12, S. 15. [in Ukrainian]. 
of an industrial property right occurs under the contract of research or development and technological works.

When characterizing the subject of the contract, the following should be noted.

The more specific the work to be created, the less likely it is that disputes arise over the parties' performance of their contractual obligations. Such features may include, in particular, the volume, type, genre, purpose, working title of the future work, the scope of its possible use, and, if appropriate, a summary of the work (plan, synopsis, etc.), its intended content. etc. The work can be created by the author and sent to the customer on a physical medium or in another form (for example, using computer equipment and transferring the results of works on the digital network $)^{19}$.

In some cases, it is useful to add drafts to the contract, a description of stylistic features, a list of actors, character descriptions, and more. This will additionally protect the customer from cases when the author transfers the rights to the created work to other persons, and will help the author to resolve disputes in case of refusal of the customer to accept the work created by the copyright contract.

Based on the content of Article 1109 of the Civil Code of Ukraine and Articles 31-33 of the Law of Ukraine "On Copyright and Related Rights", copyrights that are not valid at the time of the conclusion of the relevant contract, in particular, have not been subject to transfer (or enjoyment). at the time of the conclusion of the contract (the rights to the undeveloped object). The only exception is the contract for the creation of a custom and use of the copyright object (Article 1112 of the Civil Code of Ukraine). According to its terms, only if there are clear requirements for a work that has not yet been created (ordered), the parties have the right to determine the transfer of copyright to such object or the procedure for its use in the future.

In light of the above, the condition of a comprehensive agreement for the transfer (or use) of rights to works that do not already exist and which will be created by a party in the future in the performance of its contractual obligations without a detailed description of the requirements for such works, does not correspond to the content of the legislation and may to be declared null and void.

In order to avoid the specified risk in the agreement, the parties may, for example, provide for a suspensive condition that the provision of the contract

${ }^{19}$ Blyznets Y.A., Leontev K.B. (2009) Avtorskoe pravo i smezhnye prava: uchebnik: uchebnyk [Copyright and related rights: a textbook]. M. : Prospekt, 2009. S. 124-125. [in Russian] 
for the transfer of rights to the work not yet created at the time of the conclusion of the contract enters into force from the moment of creation of such work ${ }^{20}$.

Among the rights and obligations of the parties to the copyright contract, the following questions must be addressed: whether the author should work alone or may seek the assistance of others; whether the author may, during the term of the agreement, carry out other orders of third parties for the creation of intellectual property objects; whether the author can share some of the created object or make it known to third parties; to determine the terms and stages of acceptance of the work; the possibility of returning the work with the customer's comments for the author's revision; terms of making changes to the work, the possibility of transferring the right to use the work to third parties; order of acceptance of the order; stages of payment, etc.

The final terms of the first part of the contract are the responsibility of the author and the customer for the failure or improper performance of the obligations to create and accept the commissioned work. Such conditions may be: the responsibility of the author for the late submission of the work, the responsibility of the customer for the late acceptance of the work, etc. In practice, it is suggested in the form of responsibility for the customer to apply an advance to be left to the author, or full payment of the fee for the late acceptance of the work or for non-acceptance of the work. Penalties may be applied as a percentage of the fee ${ }^{21}$.

It is also proposed to charge the author with a penalty if this is stipulated in the contract. However, the amount of amounts charged to the author may not exceed the amount of actual damages caused by the author's failure to perform or improper performance of the contract ${ }^{22}$.

When considering the allocation of intellectual property rights to a custom-made object, you should refer to the content of Art. 430 of the Central Committee of Ukraine.

According to Part 1 of Art. 430 of the Civil Code of Ukraine provides that the personal non-proprietary intellectual property rights of the custom-made object belong to the creator of that object. In cases provided for by law,

20 Mamunia A. (2008) «Avtorstvo» v kommercheskom dogovore. Rasporyazhenie imushestvennymi pravami avtora v ramkah kompleksnogo soglasheniya ["Authorship" in the commercial contract. Disposal of property rights of the author under the framework of a complex agreement]. Yurydycheskaia praktyka, № 21 (543) ot 20.05.08 h. // http://yurpractika.com. [in Russian].

${ }^{21}$ Zavalna Zh. (2002) Osoblyvosti dohovoru zamovlennia v avtorskomu pravi [Special aspects of an ordering agreement in copyright law]. Pidpryiemnytstvo, hospodarstvo i pravo, № 12, S. 15. [in Ukrainian].

${ }^{22}$ Blyznets Y.A., Leontev K.B. (2009) Avtorskoe pravo i smezhnye prava: uchebnik: uchebnyk [Copyright and related rights: a textbook]. M. : Prospekt, 2009. S. 127. [in Russian] 
individual personal non-proprietary intellectual property rights in such an entity may belong to the customer.

This section of the article establishes that in the cases provided for by law, individual personal non-proprietary intellectual property rights in such an object may belong to the customer. In our view, this provision is contrary to Art. 266, 269, 438 of the Civil Code of Ukraine, because only the author may own personal non-property rights to the object of intellectual property rights. In addition, it should be noted that personal non-property rights are inalienable, absolute in nature, and belong to the author as long as the author exists as a subject.

Since the law did not provide either a list of personal non-proprietary intellectual property rights that may belong to the customer, or the conditions for the acquisition of such rights, in applying Art. 430 of the Civil Code of Ukraine should be based on the nature of one or another personal nonproprietary intellectual property right. Therefore, it can be concluded that the customer may have the right to ensure the integrity of the work, to counteract any encroachment on the work. In order to avoid in practice difficulties in applying Art. 430 of the Civil Code of Ukraine it is necessary for the legislator to clearly define under what conditions and what personal nonproperty intellectual property rights may belong to the customer ${ }^{23}$.

Part two of Article 430 of the Civil Code of Ukraine regulates the property relations between the customer and the contractor and establishes a rule on the commonality of ownership of intellectual property rights to the object created by order. This provision is dispositive and enables the parties to independently decide on the distribution of intellectual property rights.

\section{The contract for the creation and use of work}

Considering the contract for the creation and use of official work, it should be noted that the labor relations between employers and authors of the results of creative activities are different from those of other employees in that personal rights are granted to authors of the results of creative activities. Creators of any other results of non-creative activity do not have personal non-proprietary rights to the objects that are created. The difference between creative and any other activity that does not lead to the creation of intellectual property objects, has led to the formation of professional creative results ${ }^{24}$.

${ }^{23}$ Paladii M.V., Myronenko N.M., Zharov V.O. (etc.) (2006) Pravo intelektualnoi vlasnosti: naukovo-praktychnyi komentar do Tsyvilnoho kodeksu Ukrainy [Intellectual property right : scientific and practical commentary to the Civil Code of Ukraine]. K. : Parlamentske vydavnytstvo, S. 72. [in Ukrainian]

${ }^{24}$ Sudarykov S.A. (2009) Avtorskoe pravo: uchebnik [Copyright: a textbook]. M. : Prospekt, S. 73. [in Russian] 
With regard to the employment contract, copyright theory has long been in dispute as to what kind of legal relationship arises when creating copyright objects in connection with the fulfillment of the terms of the employment contract - single copyright or separate labor and copyright. This question was resolved in favor of the second point of view. When creating and using official works, there are both employment and copyright relationships. This position was expressed by BS Antimonov and EA Fleischitz, and also rightly supported later by V. O. Kalyatin ${ }^{25}$.

You can talk about the existence of a comprehensive agreement in the case where:

- the contract for the creation and use of official works is a set of two independent obligations: labor (in the general order of creation of the work) and copyright (in the order of disposal of economic rights to the work);

- the existence of a single contract for the creation and use of official work is an admission of contractual technique, which is aimed at simplifying the contractual process. In fact, it is possible to conclude two separate contracts labor and copyright, by which in their totality would regulate the relations on the creation and use of official work. This confirms the fact that labor and copyright obligations may exist autonomously. However, combining them into a single contract is essential. When concluding such an agreement, the peculiarities of official creativity - its copyright and labor aspects - are taken into account ${ }^{26}$.

Part one of Art. 429 of the Civil Code of Ukraine regulates the procedure for the acquisition of intellectual property rights on "service" objects of intellectual property rights, solely on the basis of their direct connection with the employment contract. This article of the Central Committee of Ukraine defines a special legal regime for an object of intellectual property right, which is created within a certain period of time, that is, within the term of a duly executed employment contract. It is this fact that is decisive for establishing an appropriate legal regime for the regulation of intellectual property rights in respect of the objects covered by this CC. The second legal fact, the existence of which is obligatory for the application of part one of Art. 429 of the Criminal Code of Ukraine, is that the result of intellectual,

${ }^{25}$ Antymonov B.S., Fleishyts E.A. (1957) Avtorskoe pravo [Copyright]. M.: Hosiuryzdat, S. 64; Kaliatyn V.O. (2000) Intellektualnaya sobstvennost (isklyuchitelnye prava): uchebnik dlya vuzov [Intellectual property (exclusive rights): a textbook for higher education]. M.: NORMA, S. 165. [in Russian]

${ }^{26}$ Zhylynkova E. (2009) Klassifikaciya dogovorov v sfere realizacii imushestvennyh prav na obekty avtorskogo prava na Ukraine [Contracts classification in the area of intellectual property rights in Ukraine]. Yntellektualnaia sobstvennost. Avtorskoe pravo y smezhnye prava, № 1, S. 48. [in Russian]. 
creative activity must be directly related to the performance of work functions (work duties) of the employee. There are no other indications that could affect the regulation of relations regarding the creation of an intellectual property object and the acquisition of the right to it in connection with the performance of an employment contract. Moreover, in Article 429 of the Civil Code of Ukraine, the legislator focused not on identifying the features of intellectual property rights created under certain conditions but on the subjective composition of the legal relationship ${ }^{27}$.

It is believed that the works created by the employee during working hours are automatically official in the workplace. However, in order for the work to become official, you must:

- Before the beginning of its creation, send to the employee a written job assignment, possibly in the form of a business note, to create a certain work, part of it (in the case of co-authorship, revision, etc.). In the task it is necessary to describe as much as possible the purpose, technical requirements for the work being created, in order that in the future no one would have any doubt that it is for this, the already created work was sent a task from the employer to the author. In addition, the employer is advised to submit such a task to the employee's schedule;

- enter into an employment contract and / or civil contract detailing the assignments, technical requirements for the work created and other specifications regarding the work $^{28}$.

In determining whether a work is created as a service, as Khokhlov V.A. points out, the following provisions should be considered:

- only the work whose creation came directly into the employee's job functions can be considered official;

- the case-law is based on the fact that the employer must prove the official nature of the work; the job title itself, the workplace do not give grounds for qualifying the work as an official;

- does not affect the recognition of the work official time and place of its creation (in practice, known cases where the work was recognized as official, although created by employees not at work, but at home);

${ }^{27}$ Paladii M.V., Myronenko N.M., Zharov V.O. (etc.) (2006) Pravo intelektualnoi vlasnosti: naukovo-praktychnyi komentar do Tsyvilnoho kodeksu Ukrainy [Intellectual property right : scientific and practical commentary to the Civil Code of Ukraine]. K. : Parlamentske vydavnytstvo, 2006. S. 62. [in Ukrainian]

${ }^{28}$ Danevych B. (2009) Raspredelenie prav na avtorstvo. Problemnye aspekty raspredeleniya prav intellektualnoj sobstvennosti mezhdu rabotnikom i rabotodatelem [Allocation of author rights. Challenges of allocation of intellectual property rights between employee and employer]. Yurydycheskaia praktyka, 2009. № 39 (61) ot 29.09.09 h. // http://yurpractika.com. [in Russian]. 
- the fact of using the materials or equipment of the organization where the author works does not lead to the definition of the work as official;

- the legal regime of an official work does not change in the case of an employee being dismissed, it also does not matter whether the employee is a full-time employee or a part-time employee;

- the official nature of the work does not change in case the employer additionally provided or, conversely, did not provide with any sums of money (increased wages, bonuses, etc.);

- the notion of "task", which as a result of clarification of the essence of the necessary actions, their actualization and localization, is capable of answering the questions in the disputed cases is essential for the correct qualification, and is not a job task. However, the mere issuance of a task outside the work function, even if performed, does not give grounds for recognition of the work as official.

The need to establish the official nature of the work is explained by the special division of rights and responsibilities between the employer and the employee in this case ${ }^{29}$.

If the primary subject of copyright (the bearer of personal non-property and economic rights of intellectual property) is the author of the work (part one of Art. 435 of the Civil Code of Ukraine), his copyrights arise at the moment of creation of the work (part of Art. 437 of Civil Code of Ukraine), and in situation, which is provided for in part one of Art. 429 of the Civil Code of Ukraine, the moment when the employee's intellectual property rights arise is determined not by the fact of creation of the object of intellectual property right, but by the fact of notification by the employee of the employer of the creation of such object. From now on, based on the content of part two of Art. 429 of the Civil Code of Ukraine parties to the employment contract - the employee and the employer must regulate their relations on the intellectual property right to the object of intellectual property rights, created in connection with the performance of the employment contract, in a civil legal way, ie contract. There is no other procedure for transferring an employee's intellectual property rights to an employer by law. From the literal interpretation of the norm of Article 429 of the Civil Code of Ukraine, it follows that the fact of creation of a work by an employee is a consequence of fulfilling their official duties, and the creation of this particular result of intellectual, creative activity is caused not by the personal creative abilities of the employee, but by job requirements, respectively, the

${ }^{29}$ Khokhlov V.A. (2008) Avtorskoe pravo: zakonodatelstvo, teoriya, praktika [Copyright: legislation, theory, practice]. M. : «Horodets», S. 76-77. [in Russian] 
work is a natural result production activity of the employee as any natural person occupying this position ${ }^{30}$.

The intellectual property rights of the object created in connection with the performance of the employment contract belong to the employee who created the object and the legal or natural person where or in which it works. This provision is dispositive and, with the agreement of the parties, may be stipulated otherwise in the contract.

There are two opposing views on the issue of remuneration for authors of official works, which are based on the question of what the author should receive remuneration for: for the creation of the work or for its use. According to the first, royalties are paid to the author in the form of wages. Supporters of the other believe that wages are only remuneration for scientific and creative work, not for industrial or commercial use of the work. In this case, there should be a separate fee, depending on the particular use of the work. The reward is the sense of existence of the copyright institute itself, the main object of the authors' requirements. National law of different countries generally recognizes the right of the author of a work of work to receive, in addition to wages, a separate royalties due to the use of the results of his creative work $^{31}$.

Under the agreement on the transfer of exclusive intellectual property rights, one party (a person who has exclusive rights) transfers to the other party, in part or in full, these rights in accordance with the law and under the terms and conditions specified in the contract (Part 1 of Article 1113 of the Civil Code of Ukraine).

The essential terms of a contract for the transfer of exclusive intellectual property rights are: the term of the contract, the ways of using the work, the territory to which the transferable right extends, the amount and procedure of payment of royalties, as well as other conditions on which at the request of one of the parties to be agreed.

However, the terms of the contract for the transfer of exclusive intellectual property rights that impair the position of the creator of the respective object or its heirs in comparison with the situation stipulated by the Civil Code of Ukraine or other law, and also limit the creator's right to create other objects, are null and void.

${ }^{30}$ Paladii M.V., Myronenko N.M., Zharov V.O. (etc.) (2006) Pravo intelektualnoi vlasnosti: naukovo-praktychnyi komentar do Tsyvilnoho kodeksu Ukrainy [Intellectual property right : scientific and practical commentary to the Civil Code of Ukraine]. K. : Parlamentske vydavnytstvo, 2006. S. 63. [in Ukrainian]

${ }^{31}$ Bondarenko S.V. (2008) Avtorske pravo ta sumizhni prava [Copyrigh and related rights]. K. : In-t intel. vlasn. i prava, S. 71. [in Russian] 


\section{The contract of commercial concession (Franchising)}

According to Art. 1115 of the Civil Code of Ukraine under the contract of commercial concession one party (right holder) undertakes to grant to the other party (user) for payment the right of use according to its requirements by a complex of rights belonging to that party for the purpose of production and / or sale of a certain type of goods and (or) services.

In concluding a commercial concession agreement, in addition to the provisions of the Civil Code of Ukraine, Civil Code of Ukraine, the provisions of special normative acts governing the relations in the sphere of turnover and protection of rights to certain types of intellectual property objects should be taken into account.

The essential features of a commercial concession are that under a commercial concession agreement, the right holder grants the user the right to use for a fee a set of exclusive intellectual property rights to promote the promotion of goods (services) in a particular market. The requirements stipulated by law and which can be included in the contract include instructions on the territory of use, the sphere of civil turnover, the right to enter into a commercial sub-concession agreement, the obligation to carry out state registration of the contract, the transmission of technical and commercial documentation, quality control of goods, etc.

Franchising in practice is implemented in various forms. It is customary to classify by species by different criteria. Most often in the legal literature, franchising is classified by type according to the functions it performs. In the Franchise Guide, WIPO is divided into three types of franchising:

- franchise for processing (production);

- franchise for services (service);

- Wholesale franchise (distribution).

The basis of this division is historically the way and the amount of activity that the user performs under the franchise stipulated in the commercial concession agreement ${ }^{32}$.

In other words, the basis of the division is the amount of rights regarding possible activities that can be performed under a commercial concession agreement by the user ${ }^{33}$, depending on the nature of the economic relations ${ }^{34}$.

Production franchising is widely represented in the production of soft drinks (Coca-Cola, Pepsi and Seven-Up). It should be noted that using this type of

${ }^{32}$ VOIS (1995) Rukovodstvo po franshize [Franchising guide]. Zheneva: VOIS, 1995. S. 15. [in Russian]

${ }^{33}$ Biloshytskyi S. (2008) Modeli dohovoriv komertsiinoi kontsesii [Models of franchise agreement]. Pravovyi tyzhden, № 13 (86) vid 25.03.2008 r., S. 8. [in Ukrainian].

${ }^{34}$ Klymenko A. (2004) Dogovor franchajzinga - analiz soderzhaniya [Franchise agreement content analysis]. Nalohy y bukhhalterskyi uchët, № 74 (736) ot 13.09.2004, S. 25. [in Russian]. 
commercial concession agreement, the user carries out the entire production cycle of manufacturing the final product under the trademark of the right holder. In this case, the right holder provides the user with the necessary ingredients, ingredients, equipment, and the other party, ie the user, produces the final product under the trademark and has the right to distribute it to consumers ${ }^{35}$.

When franchising services are provided, technology is provided to provide services to hotels (Holiday Inn, Hilton, Marriotvn), peters, fast food establishments (McDonald's, Pizza Hut, etc.), branded car service stations, gas stations, insurance companies, banks, etc ${ }^{36}$.

Business franchise ("package - franchise") ${ }^{37}$ is a method of doing business in such a way that the right holder benefits from the rapid growth of the franchise network at limited costs and risk, and the user - from the right to use a proven commercial system.

When entering into such an agreement, the right holder grants the right of use to private individuals or legal entities to open shops, supermarkets for sale to buyers of a set of products or services under the rightholder's name and trademark. In Ukraine, a business concession is used, for example, "Silpo"38.

\section{CONCLUSIONS}

Under a commodity (trade) franchise agreement, the user purchases the right of the parent company to sell goods with its trademark (in fact, it is a right to sell goods on behalf of the manufacturer). Official car dealers can be cited as an example of such a commercial concession. Merchant Franchising (Merchant Franchising) is a way of doing business whereby a copyright holder who manufactures a product grants the right to sell its products to the user, with the obligatory use of the trademark for the goods and services of the right holder and in a clearly defined franchise territory ${ }^{39}$.

The second classification of franchising is related to internationalization of business. Depending on the method of organization, structure and relationships of the franchise network distinguish the following models of franchising ${ }^{40}$ :

${ }^{35}$ Biloshytskyi S. (2008) Modeli dohovoriv komertsiinoi kontsesii [Models of franchise agreement]. Pravovyi tyzhden, № 13 (86) vid 25.03.2008 r., S. 8. [in Ukrainian].

${ }^{36}$ Sudarykov S.A. (2009) Sudarikov S.A. Pravo intellektualnoj sobstvennosti: uchebnik [Intellectual property right: a textbook]. M. : Prospekt, 2009. S. 284. [in Russian]

${ }^{37}$ Leheida E. (1996) Franchaizynh. Novaia forma orhanyzatsyy byznesa [Franchising. A new form of business organization]. Byznes - ynform, № 20, S. 32. [in Russian].

${ }^{38}$ Biloshytskyi S. (2008) Modeli dohovoriv komertsiinoi kontsesii [Models of franchise agreement]. Pravovyi tyzhden, № 13 (86) vid 25.03.2008 r., S. 8. [in Ukrainian].

39 Biloshytskyi S. (2008) Modeli dohovoriv komertsiinoi kontsesii [Models of franchise agreement]. Pravovyi tyzhden, № 13 (86) vid 25.03.2008 r., S. 8. [in Ukrainian].

${ }^{40}$ VOIS (1995) Rukovodstvo po franshize [Franchising guide]. Zheneva: VOIS, 1995. S. 50. [in Russian]; Leheida E. (1996) Franchaizynh. Novaia forma orhanyzatsyy byznesa [Franchising. A new form of business organization]. Byznes - ynform, № 20, S. 32. [in Russian]. 
- direct franchising (classic franchising, regional commercial concession agreement) - the contract is concluded between the right holder located in one country and the user located in another country. This scheme is possible if the countries are geographically nearby and they have related culture and customs. In this case, the right holder controls the business of the user. The classic model, also called direct franchising, involves a direct relationship between the right holder and the user. The rights holder himself searches for the user's applications, negotiates with them and enters into contracts. The direct franchise model is most effective when the right holder and the user are in the same state. Franchising network in direct franchising can be built on two basic principles: the conclusion of simple contracts between the right holder and one or more users to open one franchise point to each user (single element franchise), concluding with one or more users franchisee to develop contracts for the development of franchise. Most often, combinations of these methods are used in one network.

- indirect franchising (developing franchising, that is, a development concession agreement) - this type is used when countries are geographically distant from one another and there are significant differences in culture, customs, language barrier. Structural elements of the franchising system are subsidiaries, branches, joint ventures. In this case, the established businesses ensure the adaptation of the franchise system to the local conditions, as well as provide direct communication between the right holder and the user. An example of this type is the creation of a McDonald's restaurant chain in Ukraine. The development contract provides for the opening by the user of several franchise points in the specified contract area and for a specified period. In this case, a separate franchise agreement is signed for each new point. In other words, the user is obliged to open the number of franchise points discussed, and the right holder guarantees to conclude an appropriate number of franchise agreements with him.

- master franchising (sub-franchising, sub-concession) - in this case the contract is concluded for the purpose of organization of franchising enterprises, ie the scheme of relations can be displayed in the following way: right holder - main user - user. The disadvantage of such a system is the inability to effectively control user activity.

The division of such models is based on the emergence of new, additional parties to the commercial concession agreements and, as a result, related features in the rights and obligations of the parties that are determined during the conclusion of the commercial concession agreement. In new models, in addition to the already mentioned subjects of the commercial concession 
agreement, such as the right holder and the user, there are additional parties: the main user, the sub-user, the developing user $^{41}$.

A commercial concession contract can be based on the combination of several models and combine, for example, a territorial concession and a developing concession.

\section{SUMMARY}

For the person who created the result of intellectual activity (intellectual product), the conclusion of the contract is one of the legal forms of realization of rights to the results of intellectual activity. Intellectual property performance treaties have a specific nature that sets them apart from other treaties. The results of intellectual activity are intangible and can be embodied in the material medium. Intellectual property rights are limited in time and space. In addition, the results of intellectual activity can be used not only by the entity but also by others. That is, the right holder can not only use the intellectual product independently, but at the same time give permission for its use to other interested persons. Intellectual property performance contracts are concluded only for those intellectual products that are recognized by law enforcement as required by law.

\section{REFERENCES}

1. Iakubivskyi I. (2007) Dohovory shchodo rozporiadzhannia mainovymy pravamy intelektualnoi vlasnosti za zakonodavstvom Ukrainy [Agreements on the disposal of intellectual property rights under the legislation of Ukraine]. Pidpryiemnytstvo, hospodarstvo ta pravo, № 8, S. 16. [in Ukrainian].

2. Kryzhna V. (2004) Zahalna kharakterystyka dohovoriv shchodo rozporiadzhennia mainovymy pravamy intelektualnoi vlasnosti [General characteristics of the agreements on the disposal of intellectual property rights]. Pravo Ukrainy, № 9, S. 68. [in Ukrainian].

3. Ruzakova O. (2008) Problemy postroeniya sistemy dogovorov o sozdanii rezultatov intellektualnoj deyatelnosti i rasporyazhenii isklyuchitelnymi pravami [Challenges in constructing the system of agreements on the creation of intellectual deliverables and exclusive rights]. YS. Avtorskoe pravo y smezhnye prava, № 6, S. 26. [in Russian].

4. Naumova E. (2008) Dogovornoe regulirovanie oborota prav na intellektualnuyu sobstvennost [Contractual regulation of the circulation of

${ }^{41}$ Biloshytskyi S. (2008) Modeli dohovoriv komertsiinoi kontsesii [Models of franchise agreement]. Pravovyi tyzhden, № 13 (86) vid 25.03.2008 r., S. 8. [in Ukrainian]. 
intellectual property rights]. Yntellektualnaia sobstvennost. Avtorskoe pravo y smezhnye prava, № 6, S. 70-71. [in Russian].

5. Kuvyrkova A.Yu. (2009) Licenzionnyj dogovor o predostavlenii prava ispolzovaniya obekta intellektualnyh smezhnyh prav [License agreement on granting the right to use the object of intellectual related rights]. Zakonodatelstvo, № 5, S. 58. [in Russian].

6. Melnyk O. (2003) Dohovory u sferi intelektualnoi vlasnosti za novym Tsyvilnym kodeksom Ukrainy [Intellectual property contracts under the new Civil Code of Ukraine]. Pidpryiemnytstvo, hospodarstvo ta pravo, № 9, S. 8. [in Ukrainian].

7. Dobrynina H. (2007) Litsenziina diialnist shchodo obiektiv prava intelektualnoi vlasnosti [Licensing activity towards intellectual property objects]. Spravochnik ekonomista, № 3. S. 5. [in Ukrainian].

8. Levchenko D. (2006) Aspekty licenzionnyh dogovorov. Otnositelno licenzionnyh dogovorov o peredache prav na obekty intellektualnoj sobstvennosti [Aspects of license agreements. On license agreements on the assignment of intellectual property rights]. Yurydycheskaia praktyka, № 11, S. 22. [in Russian].

9. Kyryliuk A.V. (2008) Litsenziinyi dohovir na vykorystannia literaturnykh tvoriv: poniattia, umovy, forma [License agreements on the use of literary writings: concept, conditions, form]. Aktualni problemy derzhavy $i$ prava, № 41, S. 192. [in Ukrainian].

10. Sorokyna L.V. (2008) Otgranichenie avtorskogo dogovora zakaza ot smezhnyh dogovorov [Delimitation of commissioning agreement from related agreements]. Rossyiskyi yurydycheskyi zhurnal, № 5, S. 204. [in Russian].

11.Zavalna Zh. (2002) Osoblyvosti dohovoru zamovlennia v avtorskomu pravi [Special aspects of an ordering agreement in copyright law]. Pidpryiemnytstvo, hospodarstvo i pravo, № 12, S. 15. [in Ukrainian].

12. Mamunia A. (2008) «Avtorstvo» v kommercheskom dogovore. Rasporyazhenie imushestvennymi pravami avtora $\mathrm{v}$ ramkah kompleksnogo soglasheniya ["Authorship" in the commercial contract. Disposal of property rights of the author under the framework of a complex agreement]. Yurydycheskaia praktyka, № 21 (543) ot 20.05 .08 h. // http://yurpractika.com. [in Russian].

13. Zhylynkova E. (2009) Klassifikaciya dogovorov v sfere realizacii imushestvennyh prav na obekty avtorskogo prava na Ukraine [Contracts classification in the area of intellectual property rights in Ukraine]. Yntellektualnaia sobstvennost. Avtorskoe pravo y smezhnye prava, № 1, S. 48. [in Russian].

14. Danevych B. (2009) Raspredelenie prav na avtorstvo. Problemnye aspekty raspredeleniya prav intellektualnoj sobstvennosti mezhdu rabotnikom 
i rabotodatelem [Allocation of author rights. Challenges of allocation of intellectual property rights between employee and employer]. Yurydycheskaia praktyka, 2009. № 39 (61) ot 29.09 .09 h. // http://yurpractika.com. [in Russian].

15. Klymenko A. (2004) Dogovor franchajzinga - analiz soderzhaniya [Franchise agreement - content analysis]. Nalohy y bukhhalterskyi uchët, № 74 (736) ot 13.09.2004, S. 25. [in Russian].

16. Biloshytskyi S. (2008) Modeli dohovoriv komertsiinoi kontsesii [Models of franchise agreement]. Pravovyi tyzhden, № 13 (86) vid 25.03.2008 r., S. 8. [in Ukrainian].

17. Leheida E. (1996) Franchaizynh. Novaia forma orhanyzatsyy byznesa [Franchising. A new form of business organization]. Byznes - ynform, № 20, S. 32. [in Russian].

Information about the author: Svitlana Mazurenko,

$\mathrm{PhD}$ in Law, Associated Professor at the Department of Intellectual Property Law, National University "Odessa Law Academy" 2, Academychna str., Odessa, 65009, Ukraine 


\section{STATE SYSTEM GUARANTEES: THEORETICAL AND LEGAL CHARACTERISTICS}

\section{Larysa Nalyvaiko}

\section{INTRODUCTION}

In the legal literature, more and more attention is paid to state system. The formation of a modern state system necessitates a scientific search in the field of guarantee in order to ensure its adequacy to the realities and prospects of socio-political development. At present, there is no comprehensive substantiated approach to defining the concept, features, classification criteria and types of state system guarantees.

Thematic actualization is related to the fact that the formation of the rule of law and civil society in Ukraine is directly related to the problem of creating a system of effective state system guarantees, the solution of which is based on the development and application of beneficial conditions, techniques and mechanisms for their implementation in public relations. After all, no matter what high authority the norms which fix the state system have, possessing a priority position not only in the Constitution, but in the whole system of legislation of Ukraine, they have to be effectively implemented in actual social relations. Creating an independent, constitutional and social state with a democratic system of government is a paramount task on the path to stability, and having effective guarantees is a prerequisite for its existence.

The state system guaranteeing is actualized by the need to improve the activity of the state as a whole and of separate bodies of state power which are intended to ensure the stability of its basic principles and institutions. The existence of a system of state system guarantees is a mandatory consequence of the existence and formation of a certain type of state system. In the absence of state system guarantees, the possibility of considering it as a functionally and structurally stable, political and legal phenomenon is lost.

\section{The concept and features of state system guarantees}

In jurisprudence, there is hardly another category that is so commonly used and, at the same time, has such a broad semantic form which contains a wide variety of meanings. This category is guarantees. In some cases we are talking about guarantees of legality, in others - about legality as a guarantee, about guarantees of the constitutional order, about guarantees of law and order, about law enforcement guarantees and law enforcement as a guarantee, 
about guarantees of the rights and freedoms of citizens and about the rights of a person as a guarantee of his freedom, etc.

Generally, the guarantee is an ideal model according to which the legal and factual status of a particular state as a whole should be shaped.

Guarantees are one of the main issues in the problem of the correct application of legal norms, the assurance of legality and many other processes of legal validity. The concept of guarantee is quite widely used in various spheres of human activity, in politics, philosophy, diplomacy, as well as in everyday, non-professional word usage ${ }^{1}$.

Studies of individual theoretical aspects of the state system and elements of the system of its guarantees were carried out by domestic and foreign scientists: M. Abdulaiev, N. Bobrova, M. Vitruk, T. Zavorotchenko, A. Kolodii, V. Kopieichikov, V. Korelskyi, V. Kotiuk, I. Magnovskyi, M. Marchenko, O. Mickiewicz, O. Negodchenko, M. Orzikh, V. Perevalov, V. Pogorilko, A. Polianskyi, Zh. Pustovit, Yu. Sokolenko, M. Stavniichuk, E. Supruniuk, V. Tatsii, Yu. Todiuk, O. Fritskyi, V. Shapoval, Yu. Shemshuchenko, Yu. Shymin and others.

Humanity has always sought to create a system of democracy that would truly be democratic and would protect their rights and freedoms, and without a credible mechanism of guarantee this would seem impossible. For a long time, scientists have sought to show at the theoretical level the need to create legitimate social institutions that should guarantee the existence of a democratic state system.

From the legal and technical side, the guarantee can be described as the proper activity of the subjects of law for the purpose of realization, actualization of certain social interest provided by legal protection. In such a context, the state of guaranteeing is determined by certain positive activities of the subjects of law, and in case of a breach of the balance of their interests, by the need for the use of instruments of legal protection and legal responsibility ${ }^{2}$.

In the theory of state and law, under "guarantees" some scholars understand the system of conditions, means and methods that provide each and every level of opportunity ${ }^{3}$. Others define "guarantees of democracy" as objective conditions and means that ensure not only the proclamation and

${ }^{1}$ Nalyvajko L.R. (2005) Gharantiji derzhavnogho ladu Ukrajiny: problemy vyznachennja ponjattja [State system of Ukraine guarantees: problems of definition of the concept]. Naukovyj visnyk Jurydychnoji akademiji Ministerstva vnutrishnikh sprav, no. 4 (24), pp. 153-159.

${ }^{2}$ Nalyvajko L.R. (2009) Derzhavnyj lad Ukrajiny: teoretyko-pravova modelj [State system of Ukraine: theoretical and legal model]: monoghrafija. Kharkiv: Pravo.

3 Korel'skiy V.M., Perevalov V.D. (1998) Teoriya gosudarstva i prava [Theory of Government and Rights]: uchebnik. Moskva: Infra-M, P. 504. 
legal consolidation of democratic principles, ideas, rights and freedoms of citizens, but also their comprehensive protection and implementation ${ }^{4}$. P. Rabinovych believes that the "guarantees of legality" are a system of means by which legitimacy is introduced, protected and, in the event of a breach, established in public life. In its turn, the scientist defines "legal guarantees of legality" as special means of introduction, protection and, in case of violation, restoration of legality ${ }^{5}$.

In modern science, from the standpoint of reflecting the guarantees of the rights and freedoms of man and citizen in the political and legal thought, I. Magnovskyi examines the ideas of Ukrainian scientists of the late $19^{\text {th }}-$ the first half of the $20^{\text {th }}$ century (M. Drahomanov, M. Kovalevskyi) on guaranteeing human rights ${ }^{6}$. V. Kotiuk explores "the guarantees of human and citizen rights and freedoms" as conditions, means and methods that ensure the comprehensive protection of the rights and freedoms of the individual ${ }^{7}$. $\mathrm{Yu}$. Oborotov believes that the decisive principle of forming a system of legal guarantees of rights and freedoms is the universality of their provision in all ways that are not contrary to the law. At the same time, among the legal guarantees of rights and freedoms $\mathrm{Yu}$. Oborotov distinguishes the guarantees of implementation and guarantees of protection ${ }^{8}$. In the Legal Encyclopedia S. Lysenkov, A. Taranov define guarantees of human and citizen rights and freedoms as conditions, means, ways that ensure full and complete protection of the rights and freedoms of a person ${ }^{9}$. In this context, the notion of guarantees encompasses the totality of objective and subjective factors aimed at the practical realization of rights and freedoms and the elimination of possible obstacles to their full or proper exercise.

Thus, in the theory of state and law, the main focus is on the guarantees of the realization and protection of human and citizen rights and freedoms, since the protection of individual rights is the key to the development of a democratic state.

\footnotetext{
${ }^{4}$ Marchenko M.N. (2002) Obshchaya teoriya gosudarstva i prava [General Theory of State and Law]. Akademicheskiy kurs: v 3 t, t. 3. 2-e izd., pererab. i dop. Moskva: Zertsalo-M, P. 77.

${ }^{5}$ Rabinovych P.M. (2002) Osnovy zaghaljnoji teoriji prava ta derzhavy [Fundamentals of the general theory of law and state]: navch. posib. 6-e vyd. Kharkiv: Konsum, pp. 116-117.

${ }^{6}$ Maghnovsjkyj I. (2002) Vidobrazhennja gharantij prav i svobod ljudyny ta ghromadjanyna u poghljadakh M. Draghomanova i M. Kovalevsjkogho [Reflection of guarantees of human and citizen rights and freedoms in the views of M. Drahomanov and M. Kovalevskyi]. Pravo Ukrajiny, no. 5, pp. 137-139.

${ }^{7}$ Kotjuk V.O. (2005) Zaghaljna teorija derzhavy i prava [General theory of state and law]: navch. posib. Kyjiv: Atika, P. 382.

8 Oborotov Yu.M. (1998) Suchasna derzhava: osnovy teoriji [The modern state: the foundations of theory]: navch. kurs. Odesa: Astroprynt, pp. 86-87.

${ }^{9}$ Shemshuchenko Ju. S. (ed.) Jurydychna encyklopedija [Legal Encyclopedia]: v 6 t., t. 1 : A-Gh. K. : Ukr. encykl. im. M. p. Bazhana, 1998, pp. 555.
} 
In civil law, a guarantee is understood as a caution, security, pledge, a condition that protects and secures ${ }^{10}$. A guarantee in civil law is a way of securing civil obligations, relationships between the parties and the special entity.

The problems of guarantees in labour law have been investigated in the works of such scientists as: N. Bolotina, V. Rudyk, S. Syvak, V. Skobielkin, B. Stashkiv and others ${ }^{11}$. In particular, the most thoroughly analyzed are the problems of regulatory guarantee as a specific legal means of securing, implementing, safeguarding and protecting labour rights.

Investigating the content of the administrative and legal support of human and citizen rights and freedoms, I. Yerusalimova, I. Yerusalimov, P. Pavlik, J. Udovenko call it an integral guarantee, that is the legal means which safeguard and protect the rights of citizens, suspend and eliminate violations, provide opportunities for their renewal ${ }^{12}$.

In addition, it should be noted that in legal science, the content of guarantees is often limited to the protection of legal norms, in particular, the reduction of guarantees to sanctions, the establishment of liability for their violation. However, if this principle is applied to other areas of law, especially those characterized by the regulation of public relations through prohibitions, this approach is correct. However, it seems rather limited, for example, for constitutional law. The specificity of the method of legal regulation of constitutional law is determined by the social function of this branch of law, which is characterized by the ability to guarantee the existence of certain social phenomena in reality.

Considering the state of development of state system guarantees as a relatively independent problem, it is worth noting that it is at the initial stage of the study and has not been comprehensively studied. Until now, only certain parts of the state legal sphere have been objects of guarantee. In the scientific literature there are no studies on the state system guarantees. In particular, one can cite examples of the following types of guarantees being successfully researched and explored in science: "guarantees of direct democracy", "guarantees of freedom of choice of representative bodies of

${ }^{10}$ Dal' V. (1955) Tolkovyy slovar' zhivogo velikorusskogo yazika [The Explanatory Dictionary of the Living Great Russian Language]: v 4 t. Moskva: Rus. yaz.,. T. 1, P. 344.

11 Rudyk V. (2005) Pro problemni pytannja normatyvnogho gharantuvannja prava na socialjnyj zakhyst [On the problematic issues of regulatory guarantee of the right to social protection]. Pidpryjemnyctvo, ghospodarstvo i pravo, no. 9, P. 37.

12 Ijerusalimova I.O., Ijerusalimov I.O., Pavlik P.M., Udovenko Zh.V. (2007) Administratyvno-pravove zabezpechennja prav i svobod ljudyny i ghromadjanyna [Administrative and legal support of human and citizen's rights and freedoms]: navch. posib. Kyjiv: Znannja. 
power" and "guarantees of elections". Exploring the reality of direct democracy, G. Murashyn identified guarantees of both the imposition of responsibility and the enforcement of coercive sanctions against violators of constitutional norms and principles, relevant provisions of other legislative acts aimed at protecting democratic foundations of life ${ }^{13}$.

The greatest attention was paid to the "guarantees of human and citizen rights and freedoms", which, for example, are described by A. Kolodii and A. Oliinyk as a system of norms-principles, conditions and means that ensure, in their totality, the exercise of constitutional rights, freedoms and legitimate interests of human beings and citizens ${ }^{14}$. The effectiveness of this system depends on various factors, the main among which is the presence of specific elements in the system of functioning of state power ${ }^{15}$. The guarantees make the necessary transition from the legal possibility to the actual exercise of rights and freedoms. For this reason, general guarantees are understood in the literature as those which encompass the totality of objective and subjective factors aimed at eliminating possible causes and obstacles to their improper implementation. And special (legal) guarantees are interpreted as legal means and methods by which the rights and freedoms of a person are realized, safeguarded and protected, and the violated rights are eliminated or renewed $^{16}$. The literature states that, on the whole, scholars are unanimous in their belief that the system of guarantees of human and citizen rights and freedoms includes the economic, political, social, moral, international, organizational and legal prerequisites necessary for securing and effective implementing, and comprehensive safeguarding of rights and freedoms of the individual, as well as the mechanism of their protection ${ }^{17}$. In monographs and other doctrinal studies a comprehensive analysis of the institute of constitutional rights and freedoms of man and citizen and problems of their guaranteeing has been made. The unity of approaches is that in the general

${ }^{13}$ Murashyn Gh.O. (2001) Gharantiji bezposerednjoji demokratiji [Guarantees of direct democracy]. Konstytucijno-pravovi formy bezposerednjoji demokratiji v Ukrajini: problemy teoriji i praktyky. Do 10-ji richnyci nezalezhnosti Ukrajiny. Kyjiv: In-t derzhavy i prava im. V.M. Korecjkogho NAN Ukrajiny, pp. 328-352

${ }^{14}$ Kolodij A.M., Olijnyk A.Yu. (2003) Prava ljudyny i ghromadjanyna [Human and citizen rights]: navch. posib. Kyjiv: Jurinkom Inter, P. 223.

${ }^{15}$ Olijnyk A.Yu. (2008) Konstytucijno-pravovyj mekhanizm zabezpechennja osnovnykh svobod ljudyny i ghromadjanyna v Ukrajini [The constitutional and legal mechanism for ensuring the fundamental freedoms of man and citizen in Ukraine]: monoghrafija. Kyjiv: Alerta; KNT; Centr navchaljnoji literatury, P. 157.

${ }^{16}$ Bessonova M., Birjukov O., S. Bondaruk (ed.) (2002) Osnovy demokratiji [Fundamentals of democracy]: navch. posib. dlja stud. vyshh. navch. zakl. Kyjiv: Aj Bi, P. 179.

${ }^{17}$ Zavorotchenko T. (2002) Systema konstytucijno-pravovykh gharantij i svobod ljudyny i ghromadjanyna v Ukrajini [The system of constitutional legal guarantees and freedoms of human and citizen in Ukraine]. Pravo Ukrajiny, no. 5, P. 110. 
form guarantees are characterized as rules, conditions, means and methods that ensure the effective implementation of the statutory capacity of human and citizen.

The general theoretical guarantee can be defined as a certain phenomenon that ensures a concrete positive result.

Terminological ambiguity in the sphere of state system guaranteeing in terms of its democratic modification adversely affects both the development of legal doctrine and the practice of state formation.

All social conditions, factors, phenomena that are part of the process of formation of the Ukrainian state system, which affect it, create a social background (environment), are considered for the subject of their guaranteeing power through the legal prism and legal "equivalent", through those criteria produced by the legal science, which allow us to distinguish the general prerequisites of reality, the state system guaranteeing from the actual guarantees of its implementation in the aspect of ensuring democracy and stability.

Scientific elaboration of this problem allows to define the Ukrainian state system guarantees as a system of general conditions and special (normativelegal and organizational-legal) means that ensure the existence and effectiveness of institutions of the state system.

The state system guarantees serve as a basis for the formation of certain social relations that have a common specificity. This allows them to be grouped together and characterized by distinguishing common features that are inherent in state system guarantees in general.

I would like to emphasise that in socio-political science the term "guarantees" is often used when it comes to principles. N. Bobrova explains this with the ambiguity of the term "guarantee", the authority and validity of its perception by citizens ${ }^{18}$. In legal science, the use of the term "guarantees" in the sense of prerequisites is unjustified. To designate general social guarantees a special term "principles" was created by jurisprudence.

Appeal to the principles (foundations, prerequisites) in the study of guarantees is explained, in addition, by the tendency of generalized coverage of guarantees of complex state-legal phenomena. "General guarantees" must be viewed through the prism of their true and probable anchorage, and differentiated with respect to the guaranteed object.

Hereafter, we will consider the basic features inherent in the Ukrainian state system guarantees.

1. Formal certainty. The state system guarantees, first of all, are enshrined in the Constitution and legislation of Ukraine. The role of the Constitution and

${ }^{18}$ Bobrova N.A. (1984) Garantii realizatsii gosudarstvenno-pravovykh norm [Guarantees of implementation of state legal norms]. Voronezh: Izd-vo Voronezh. un-ta, P. 28. 
laws of Ukraine in the state system guaranteeing is recognized by many researchers. Moreover, in a number of works it is pointed out that the Constitution (as a normative legal act of the highest legal force) is not only a guarantee of the stability of the state system, but also in general, is a condition for its existence ${ }^{19}$.

2. Systematicity. The systematicity of state system guarantees is determined, first of all, by the principle of systematicity of law. Systematicity of law, in turn, is a manifestation of social processes. The system of law in action is the interoperability of its individual elements, where the effectiveness of the whole chain of guaranteeing depends on the individual link, since the interconnection of phenomena helps to understand their essence more deeply. The system of state system guarantees can vary (for example, the range of subjects - government guarantors may be narrowed or expanded). However, the existence of these guarantees is a necessary consequence of the existence and formation of a state system of a certain type.

3. Purposefulness. First of all, ensuring any relationship or process is the basis of the concept of guarantees. This feature makes it possible to distinguish this legal phenomenon from others, such as subjective law, legal obligation, to single it out into an independent category, if the legal phenomenon does not ensure the achievement of the purpose, which is set in a certain phenomenon, it cannot be considered a guarantee ${ }^{20}$. In addition, the guarantee cannot exist as an independent phenomenon, regardless of the specific object, because the securing process always involves the presence of the object.

4. Procedurality. The realization of the goal set out in the guarantees implies the existence of procedural actions without which it is impossible to achieve a positive result. State system guarantees are largely determined by the behavior and activities of the subjects concerned. Therefore, when determining the state system guarantees, first of all, it must be assumed that they in any case have the subject of the activities of the relevant subjects. The subjects that ensure the sustainable functioning and development of the state system include: the Verkhovna Rada of Ukraine, the President of Ukraine, the Cabinet of Ministers of Ukraine, citizens of Ukraine, state-owned enterprises, institutions, organizations and more. Their activities are aimed at guaranteeing the rule of law.

5. Materiality. This feature is characterized by the fact that the state system guarantees are contained and enshrined in the norms of law, embodied in the acts of enforcement. Mandatory prerequisites for the possible and

${ }^{19}$ Poghorilko V.F. (1997) Osnovy konstytucijnogho ladu Ukrajiny [Fundamentals of the constitutional system of Ukraine]. Kyjiv: In Jure, P. 95.

${ }^{20}$ Skobelkin V.N. (1969) Yuridicheskie garantii trudovykh prav rabochikh i sluzhashchikh [Legal guarantees of labour rights of workers and employees]. Moskva: Nauka, P. 10. 
proper conduct of persons exercising power are legal acts that determine the conditions under which certain persons acquire a specific subjective right and have an appropriate legal obligation.

6. The permanent nature of the guarantees and the determination of the powers of the guarantor subjects. That is, the existence of actions or events with which the rules of law are associated with the occurrence of legal consequences, indicates the period of validity of guarantees, and in accordance with the constitutional principle of organization and activity of public authorities, we have a clear determination of their powers. For example, in the activity of such a subject of the state system as the Verkhovna Rada of Ukraine, the functioning of the guaranteeing mechanism begins after the occurrence of legal facts that determine the conditions for acquiring parliamentary powers, and ends with the termination of powers of the deputy, that is, the end of certain events and actions (sessions, meetings, etc.) or the attainment of a goal stipulated in the rule of law on the possible or proper conduct of a deputy, etc.

7. Effectiveness. The effectiveness of a legal phenomenon has traditionally been defined as the ratio between the actual result of the action of legal norms and those social goals to achieve which these norms were adopted $^{21}$. The research area is the most complex criteria for measuring performance, diffusion, systemic action and counteraction. It is virtually nondimensional, such as quantitative indicators of economic or legal effectiveness. It is difficult to apply the methods of specific sociology together with all the criteria for its measurement. Another feature of the effectiveness of state system guarantees is that it always has a political side associated with the development of democracy, the rule of law, and therefore it must be evaluated no less than the achievement of results in the economic sphere.

Indicators of the effectiveness of state system guarantees are both the qualitative state of the norms of the Constitution and other normative legal acts, as well as the mechanism of ensuring their implementation in social reality.

8. Adequacy of guarantees (orientation to the real level of development of public relations). The norms that correspond to the level of development of social relations, consistent with the system of law can be guaranteed.

The specificity of their legal nature is influenced by the implementation of the rules guaranteeing the state system order. They are an important constituent of the Constitution, have a high level of normative generalizations, have a special content and in a concentrated form fix the basic provisions on the organization and functioning of the state and its institutions.

${ }^{21}$ Bobrova N.A., Zrazhevskaya T.D. Otvetstvennost' v sisteme garantiy konstitutsionnykh norm (gosudarstvenno-pravovye aspekty) [Responsibility in the system of guarantees of constitutional norms (state and legal aspects)]. Voronezh: Izd-vo Voronezh. un-ta, 1985, pp. 124-126. 
The unity of the distinguished features characterizes the mechanism of guaranteeing state system, which ensures the smooth and efficient functioning of both the whole state mechanism and the state as a whole.

\section{State system guarantees: classification criteria and types}

The classification of guarantees is to some extent derived from the classification of the asset being guaranteed. Just as the choice of means to achieve any goal depends on the goal itself, so are the state system guarantees due to certain objects in need of guarantee. The derivation of classification criteria and relatively independent types of state system guarantees is based on the analysis of ideas, theories, doctrines and is conditioned by the historical, legislative, national and other features of the development of this institute.

Various classification criteria can be based on the classification of state system guarantees: the form of securing guarantees; the scope of the guarantees; the degree of their state security; the nature of the legal rules governing the state system; the relationship between the state and the citizen and other criteria. Depending on this, different approaches can be devised to divide state system guarantees into groups.

Traditionally, both in the theory of state and law, and in constitutional law, depending on the content and type of social activity, it is customary to allocate general and special (legal) guarantees.

General (social) guarantees are a set of objective and subjective factors that are aimed at practical implementation and comprehensive protection, elimination of possible causes and obstacles to the formation of a democratic state system in Ukraine. It is expedient to divide the general state system guarantee by the spheres of the state system into economic, political, social, ideological and cultural (spiritual).

It is worth noting that the economic state system guarantees are regulated by the Constitution and other normative legal acts of Ukraine, economic conditions and possibilities of implementation of the constitutional and legal regulations, the ability of the society and the state to provide the necessary material and financial resources for establishing a democratic state system in Ukraine. Economic guarantees are important in the system of state system guarantees, because they provide for the availability of appropriate environment and material basis for the stable functioning of the state.

Political guarantees of the state system are the system of democracy, appropriately oriented state policy, provided by the Constitution and other normative legal acts of Ukraine, aimed at democratization of the Ukrainian state system as a set of state and non-state institutions that exercise power, control of the society, ethnic and other groups, provide stability in the society, the corresponding order in it. Political guarantees of the state system are a set 
of political factors that ensure the promotion of a democratic legal regime in the country.

Social guarantees of the state system are a set of social conditions created and secured by the state, a system of social relations, unimpeded and free functioning of the institutions of a developed civil society, the state and the individual, the prevention of crisis phenomena in society and deepening the content of the legal status of a renewed state with a democratic state system based on the principles of humanism, justice, equality, and the expansion of real conditions in realizing the capabilities of each individual.

Social guarantees include a qualitatively new form of civic life that demonstrates a completely different relation between society, state and personality, its relation to other personalities and to itself ${ }^{22}$.

Economic, political and social guarantees create a set of conditions that ensures the development of the Ukrainian state system in a new vector of democratization and approximation to world standards.

Ideological guarantees of the state system are state-guaranteed ideological diversity, inadmissibility of recognition of any ideology obligatory by the state, prohibition of censorship, a system of moral and legal representations of personality. The ideological guarantees of the state system are the system of worldviews of the individual, which does not separate himself from the state. Such guarantees include the general and legal culture of society, ideological pluralism, the prohibition of the monopolization of ideology, democratic public opinion, and the like. These guarantees also include the activities of the state, its bodies, officials, local self-government bodies and society as a whole in the legal education of the population, which allows a person to participate more competently in making important socially important decisions.

The cultural (spiritual) guarantees of the state system are the system of cultural and spiritual values of the individual, proper cultural and educational level of the state, consolidation and development of the Ukrainian nation, its historical consciousness, traditions and culture. They are determined by the cultural function of the state and the existing systems of education, science, culture, art, information in the state and by the stable historical traditions in the sphere of cultural development of the state.

All, both general and special (legal) guarantees work in combination. General guarantees in general influence, create the basis for the existence of a democratic state system. But, even if such a system of guarantees is in place, its practical implementation is ensured, above all, by effective organizational activity.

${ }^{22}$ Zavorotchenko T. (2002) Systema konstytucijno-pravovykh gharantij i svobod ljudyny i ghromadjanyna $v$ Ukrajini [The system of constitutional legal guarantees and freedoms of human and citizen in Ukraine]. Pravo Ukrajiny, no. 5, pp. 112. 
In the process of forming the rule of law, the role of special (legal) guarantees of the state system - legal forms, means and methods by which the activity of the state in general and the activity of public authorities in particular are implemented, safeguarded and protected, deficiencies are eliminated and responsibility is established for violation of the current legislation, which ensures the existence of a democratic state system - is significantly increasing.

The peculiarity of special guarantees is that they directly ensure the lawfulness of the behaviour of the subjects of public relations, so special (legal) guarantees are a system of interrelated forms, means (regulatory, institutional and procedural) and methods that ensure the existence, effectiveness and the security of public institutions.

Special (legal) guarantees can be divided into two groups: normative-legal and organizational-legal, which form a unity, which is special organizationallegal guaranteeing.

Among the guarantees of the Ukrainian state system, the most important are the normative-legal guarantees. Normative-legal state system guarantees are a system of legal norms by which the functioning, safeguarding and protection of the Ukrainian state system are ensured. These include the guarantees enshrined in the Constitution of Ukraine and other legal acts. From the point of view of the broad approach, the normative-legal guarantees of the state system are a complex of legal norms and means by which the democratic nature of the state system, its safeguarding and protection are ensured. Depending on the form of objectification, the normative-legal guarantees of the state system are divided into: 1) constitutional; 2) sectoral (criminal, administrative, civil, criminal-procedural, administrative-procedural, etc.).

Constitutional guarantees are a set of rules and legal mechanisms established by the Basic Law, which are the basis for guaranteeing the stability and democracy of the functioning of the state system. It is important to emphasise that constitutional guarantees are of great importance, since it is the Constitution that determines the state system, the order of formation of state bodies and their system, and in general terms their competence. It is the system of constitutional guarantees that attests to the reality of the state system, which is especially important for ensuring its effectiveness.

Sectoral guarantees are the legal norms of the relevant branches of law (administrative, civil, family, criminal, etc.), which establish the legal means, forms and methods of the state system. These guarantees are also of considerable importance, since they guarantee the regulation at the legislative level of any public relations in the sphere of securing the formation of a state system. 
Let us take a closer look at the above types of guarantees.

V. Pogorilko defined constitutional guarantees as a type of legal guarantees, a mechanism for ensuring the observance, implementation, application and use of constitutional and other norms of law by state authorities, local self-government, their officials, other individuals and legal entities $^{23}$. Constitutional guarantees have the highest legal force and are the basis of legal guarantees. Constitutional guarantees in the narrow sense are guarantees regarding the Constitution of Ukraine itself as a normative legal act. In a broad sense, the constitutional guarantees are aimed at protecting the state and public order, rights, freedoms and responsibilities of man and citizen, forms of direct democracy, the President of Ukraine, bodies of legislative, executive and judicial power, institutions of local self-government, territorial structure of Ukraine, etc. Yu. Todyk, V. Zhuravskiy note that constitutional guarantees are the means, methods and mechanisms stipulated by the Fundamental Law of Ukraine that ensure the realization of a certain institute ${ }^{24}$.

Guaranteeing the Ukrainian state system consists in establishing its own status of the Constitution and, accordingly, the status of those institutions which it secures: in limiting the possibilities of introducing changes and additions to it, ie providing the Constitution with its own stability, as well as in regulating its order of definition, protection, functioning and changes in the Ukrainian state system.

The Constitution of Ukraine has the highest legal force, defines the status of state and non-state institutions that act as guarantors of the implementation of the constitutional rules on the Ukrainian state system, which results in the functioning of the respective constitutional order. Therefore, an important guarantee of the rule of law is the stability of the Constitution. Such stability is ensured by the difficult conditions envisaged in the Constitution regarding the procedure for introducing amendments to those parts which set the foundations of the state system.

Thus, the normative legal guarantee of the state system is ensured: first, by the Constitution of Ukraine; secondly, the whole system of current legislation of Ukraine: constitutional, administrative, informational, criminal, customs, etc. The list of guarantees offered is not exhaustive.

Normative-legal guarantees of the state system in terms of the content of regulatory influence can be divided into: 1) material guarantees - norms that establish both the basic and additional foundations of the state system

${ }^{23}$ Shemshuchenko Yu.S. (ed.) Jurydychna encyklopedija [Legal Encyclopedia]: v 6 t., t. 1 : A-Gh. K. : Ukr. encykl. im. M. p. Bazhana, 1998, pp. 554-555.

${ }^{24}$ Todyky Yu.M., Zhuravsjkogho V.S. (2002) Konstytucijne pravo Ukrajiny [Constitutional Law of Ukraine]: pidruchnyk. Kyjiv: In Jure, P. 167. 
(for example, norms-principles, which are enshrined in the Constitution of Ukraine and determine the principles of an all-Ukrainian referendum, principles of suffrage in elections to state bodies and local self-government, etc.); 2) procedural guarantees - norms that establish the legal obligations of public authorities (for example, regulate the procedure for preparing, organizing and holding a popular vote and the procedure for implementing its decisions, etc.); norms of law that establish the procedure for bringing to justice the violation of the principles of the state system.

Another group of special (legal) guarantees is organizational-legal guarantees. Organizational-legal (institutional) guarantees of the state system are a system of institutions (subjects) empowered to provide the implementation, safeguarding and protection of the main elements of the state system.

The analysis of the current Constitution of Ukraine gives sufficient reason to claim that it has enshrined a relatively complete system of organizational-legal guarantees of the state system. The following subjects are included in this system: the Ukrainian people, the state as a whole and represented by its respective bodies: the Verkhovna Rada of Ukraine, the President of Ukraine, the Cabinet of Ministers of Ukraine and other executive authorities, the courts of the judicial system, the Constitutional Court of Ukraine, the prosecutor's office and other supervisory bodies, as well as other subjects (political parties, public organizations, mass media, international bodies and organizations, etc.).

Organizational-legal guarantees of the state system can be classified according to the following criteria: 1 ) by the method of creating guarantors: state and non-state; 2) depending on the scope of action: domestic and international; 3) by nature of activity: bodies-guarantors of general competence and bodies-guarantors of special competence; 4) within the territory of the competence of the guarantor bodies: national and local; 5) by the functional purpose of the guarantor bodies: organizational-political, organizational-economic, organizational-social, organizational-cultural and organizational-ideological.

The guarantors of the state system may be state and non-state. The state as a whole, its respective bodies and institutes are the basic (main) guarantors of the state system, its stability and inviolability.

In the legal doctrine, state guarantors are called "principal" 25 . However, even in view of such an exceptional role of state institutions in guaranteeing the state system (for some of them, performing this function is a priority), it is noted in the literature that defining them as "principal" guarantors requires some

25 Poghorilko V.F. (1999) Zaghaljni zasady konstytucijnogho ladu Ukrajiny [General principles of the constitutional order of Ukraine] // Konstytucijne pravo Ukrajiny [Constitutional Law of Ukraine]: pidruchnyk / za red. V.Ya. Tacija, V.F. Poghorilka, Yu.M. Todyky. Kyjiv: Ukrajinsjkyj centr pravnychykh studij, pp. 100-101. 
clarification $^{26}$. In examining the state and public authorities as the main guarantors of the state system, it should be clearly understood that the exercise of this function is not aimed at ensuring the domination and restoration of a certain political regime or the realization of the interests of the ruling political elite, but only to preserve and further develop the democratic form of the state system.

In this sense, guaranteeing the state system, maintaining its stability and inviolability are a common goal of both the state and civil society. This emphasises the general vector of the development of the state, which should make every effort to promote the implementation of the principles founded by the constitution.

Non-state actors that are the guarantors of the state system are, for example, the media, who play an important role in leading the change of public consciousness. A democratic process is impossible without information sharing. This exchange of knowledge and information brings together the various levels of the state system and enables the institutions of power to perform the functions of governing the state and society. In this context, it should be noted that political information is important, that is, the information needed to make decisions in the sphere of public authority.

The activity of the guarantors of the state system is embodied in certain organizational-legal and procedural forms ${ }^{27}$. The guarantors of the state system should be regarded as the bearers of the complex of fundamental rights and freedoms, powers and responsibilities, which are intended to act within the limits and in the manner stipulated by law. The organizational form of legal personality of the guarantors of the state system was manifested through the recognition of them, in accordance with the Constitution and laws of Ukraine, of the rights and powers exercised through legal forms and means of activity (legal procedures).

The most important element of the organizational structure of the guarantors of the state system is the form of organization of public power. Organizational autonomy of public authorities lies in their exclusive rule, independence throughout Ukraine. Public authorities gain their status by creating them in the manner prescribed by the Constitution and other normative legal acts of Ukraine. The functions of public affairs management in the state are not subject to assignment by other organizations and communities, except for the bodies of power specified in the Constitution and

${ }^{26}$ Shymin Yu.V. (2003) Systema gharantij konstytucijnogho ladu: aktualjni pytannja teoriji i praktyky [The system of guarantees of the constitutional order: current questions of theory and practice]. Bjuletenj Ministerstva justyciji Ukrajiny, no. 11, pp. 93.

${ }^{27}$ Savchyn M. (1999) Konstytucijnyj Sud Ukrajiny u mekhanizmi gharantuvannja prav i svobod ljudyny [The Constitutional Court of Ukraine in the mechanism of guaranteeing human rights and freedoms]. Pravo Ukrajiny, no. 4, pp. 35-38. 
laws of Ukraine. The basis of public authority organization is to ensure coherence in society (the equal development of social groups).

A comprehensive and thorough analysis of the problem of scientific classification of state system guarantees allows to make the following generalizations. All guarantees are interdependent, complementary, and act as a single mechanism to ensure the stability and democracy of the Ukrainian state system. The system of state system guarantees - both general and special (legal) - is not exhaustive. It can and should be expanded, acquire the greatest effectiveness, clarity, purposefulness, while defending the basic democratic principles of the Ukrainian state system. State system guarantees can also be classified by other criteria.

In order to ensure the completeness of the consideration of the theory of state system guarantees, they can be classified by other criteria. Thus, depending on the nature of legal norms, the state system guarantees can be divided into material and procedural.

It should be emphasised that, as in the previous classification, material and procedural guarantees are closely interrelated, interdependent and interconnected, since procedural guarantees are a form of implementation of material guarantees. In terms of scope, state system guarantees are divided into domestic and international law.

Classification of these guarantees by other criteria is of great importance for the development of the theory of state system guarantees and their practical implementation. In particular, according to the subject of implementation we can distinguish the following guarantees: parliamentary, presidential, judicial, prosecutorial, administrative (managerial), controlling, etc. By the subject of guarantee, they can also be divided into: national guarantees, international guarantees and guarantees provided by the state with the participation of relevant associations of citizens (political parties, trade unions, etc.). By functional orientation, legal guarantees of the state system can be divided into: guarantees of implementation, guarantees of safeguarding, guarantees of protection. In the field of safeguarding and protection of the state system guarantees can be classified by the following objectives: 1) preventive (precautionary) guarantees, which are to prevent offences affecting the sustainable functioning of the Ukrainian state system; 2) preservative guarantees, aimed at the termination of detected offences that encroach on the state system; 3) punitive guarantees, aimed at the realization of the legal responsibility of offenders who encroach on the Ukrainian state system.

All the above classifications of state system guarantees are inherently logical and justified. The classification criteria are certain features of guarantees that do not fully reflect their content, nature and substance. To summarize, it should be noted that each of these groups of guarantees is at the 
forefront of the whole system of state system guarantees, and their interaction gives the greatest practical effect in the sphere of general requirements of the development of the democratic state system of Ukraine and strengthening of the rule of law.

\section{CONCLUSIONS}

The Ukrainian state system guarantees are a system of general conditions and special (normative-legal and organizational-legal) means that ensure the existence and effectiveness of institutions of the state system. State system guarantees are interconnected and interrelated, form the appropriate system and, in the aggregate, provide for its formation, comprehensive safeguarding and reliable protection. Signs of the state system guarantees are the following: formal certainty, systematicity, purposefulness, procedurality, materiality, permanent nature of the guarantees and determination of powers of the subjects of the state system, effectiveness, adequacy of guarantees (orientation to the real level of development of social relations).

Derivation of classification criteria and relatively independent types of guarantees of the state system is based on the analysis of ideas, theories, doctrines and is conditioned by the historical, legislative, national, political and other features of the development of this institution. Various classification criteria are based on the classification of guarantees. The scientific classification, taken as a basis, allows us to consistently explore the complex, multilevel and multifaceted mechanism of guaranteeing the state system, without violating the integrity of the criteria. The application of different classification models allows to obtain a comprehensive description of the system of state system guarantees, to understand the specifics of their practical implementation. Analysis of the state system guarantees from the standpoint of the systematic approach allows to distinguish the following classification criteria and types of state system guarantees: depending on the content and type of social activity: general and special (legal) guarantees. State system guarantees in the spheres of government are divided into: economic, political, social, ideological and cultural guarantees.

Special (legal) guarantees by way of security can be divided into two groups: normative-legal and organizational-legal guarantees. Normative-legal guarantees of the state system can be classified: by the content of regulatory influence on: material and procedural guarantees; by objectification form: constitutional and sectoral (criminal, administrative, civil, criminalprocedural, administrative-procedural, etc.) guarantees. In turn, organizational-legal guarantees of the state system should be classified according to the following criteria: by the method of creating guarantors: state and non-state; depending on the scope: domestic and international; by nature 
of activity: bodies-guarantors of general competence and bodies-guarantors of special competence; by territory of competence of guarantors: national and local; by functional purpose: organizational-political, organizationaleconomic, organizational-social, organizational-cultural and organizationalideological.

Classification of these guarantees by other criteria is also important for the development of the theory of state system guarantees and their practical implementation: by the subject of implementation: parliamentary, presidential, judicial, prosecutorial, administrative (managerial), controlling, etc.; by subject of guarantee: national, international and guarantees provided by the state with the participation of relevant associations of citizens (political parties, trade unions, etc.); by functional orientation: guarantees of implementation, guarantees of safeguarding, guarantees of protection; for the immediate purposes: preventive (precautionary), preservative, punitive.

\section{SUMMARY}

The paper deals with the problem of guaranteeing state system. It is determined that the actualization of ensuring the stability and efficiency of the state system is due to the fact that not all norms that guarantee the state system are implemented and have been embodied in actual social relations. This situation is explained by the crisis of transients that are taking place not only in the legal sphere, but also in the sphere of economy, politics, culture and social life. The transition period in the legal sphere is a relatively long process of instability, incompleteness, imbalance, characterized by the unstable nature of alternatives and options for development.

It is emphasised that the purpose of state system guarantees is to create the most favorable conditions for the functioning of its institutions, so that the democratic form of the state system is not only constitutionally proclaimed "de jure", but also unimpeded, effective and consistently implemented "de facto", That is, the possibility envisaged in the law would be turned into reality. An effective system of state system guarantees is a recognized measure of its reality.

Research into the etymology of the term "guarantee" and the analysis of scientific points of view on understanding the concept of state system guarantees made it possible to formulate a definition. The Ukrainian state system guarantees are a system of general conditions and special (normativelegal and organizational-legal) means that ensure the existence and effectiveness of institutions of the state system. The features of state system guarantees are the following: formal certainty, systematicity, purposefulness, procedurality, materiality, permanent nature of the guarantees and determination of powers of the subjects of the state system, effectiveness, 
adequacy of guarantees (orientation to the real level of development of social relations).

Derivation of classification criteria and relatively independent types of state system guarantees is based on the analysis of ideas, theories, doctrines, and is conditioned by the historical, legislative, national, political and other features of the development of this institution. Various classification criteria are based on the classification of guarantees. The scientific classification, taken as a basis, allows us to consistently explore the complex, multilevel and multifaceted mechanism of guaranteeing the state system without violating the integrity of the criteria.

\section{REFERENCES}

1. Nalyvajko L.R. (2005) Gharantiji derzhavnogho ladu Ukrajiny: problemy vyznachennja ponjattja [State system of Ukraine guarantees: problems of definition of the concept]. Naukovyj visnyk Jurydychnoji akademiji Ministerstva vnutrishnikh sprav, no. 4 (24), pp. 153-159 [in Ukrainian].

2. Nalyvajko L.R. (2009) Derzhavnyj lad Ukrajiny: teoretyko-pravova modelj [State system of Ukraine: theoretical and legal model]: monoghrafija. Kharkiv: Pravo [in Ukrainian].

3. Korel'skiy V.M., Perevalov V.D. (1998) Teoriya gosudarstva i prava [Theory of Government and Rights]: uchebnik. Moskva: Infra-M [in Russian].

4. Marchenko M.N. (ed.) (2002) Obshchaya teoriya gosudarstva i prava [General Theory of State and Law]. Akademicheskiy kurs: v 3 t, t. 3. 2-e izd., pererab. i dop. Moskva: Zertsalo-M, pp. 69-88 [in Russian].

5. Rabinovych P.M. (2002) Osnovy zaghaljnoji teoriji prava ta derzhavy [Fundamentals of the general theory of law and state]: navch. posib. 6-e vyd. Kharkiv: Konsum [in Ukrainian].

6. Maghnovsjkyj I. (2002) Vidobrazhennja gharantij prav i svobod ljudyny ta ghromadjanyna u poghljadakh M. Draghomanova i M. Kovalevsjkogho [Reflection of guarantees of human and citizen rights and freedoms in the views of M. Drahomanov and M. Kovalevskyi]. Pravo Ukrajiny, no. 5, pp. 137-139 [in Ukrainian].

7. Kotjuk V.O. (2005) Zaghaljna teorija derzhavy i prava [General theory of state and law]: navch. posib. Kyjiv: Atika [in Ukrainian].

8. Oborotov Yu.M. (1998) Suchasna derzhava: osnovy teoriji [The modern state: the foundations of theory]: navch. kurs. Odesa: Astroprynt [in Ukrainian].

9. Shemshuchenko Yu.S. (ed.) Jurydychna encyklopedija [Legal Encyclopedia]: v 6 t., t. 1 : A-Gh. K. : Ukr. encykl. im. M.P. Bazhana, 1998 [in Ukrainian]. 
10. Dal' V. (1955) Tolkovyy slovar' zhivogo velikorusskogo yazika [The Explanatory Dictionary of the Living Great Russian Language]: v 4 t. Moskva: Rus. yaz.,. T. 1 [in Russian].

11. Rudyk V. (2005) Pro problemni pytannja normatyvnogho gharantuvannja prava na socialjnyj zakhyst [On the problematic issues of regulatory guarantee of the right to social protection]. Pidpryjemnyctvo, ghospodarstvo i pravo, no. 9, pp. 37-39 [in Ukrainian].

12. Ijerusalimova I.O., Ijerusalimov I.O., Pavlik P.M., Udovenko Zh.V. (2007) Administratyvno-pravove zabezpechennja prav i svobod ljudyny i ghromadjanyna [Administrative and legal support of human and citizen's rights and freedoms]: navch. posib. Kyjiv: Znannja [in Ukrainian].

13. Murashyn Gh.O. (2001) Gharantiji bezposerednjoji demokratiji [Guarantees of direct democracy]. Konstytucijno-pravovi formy bezposerednjoji demokratiji v Ukrajini: problemy teoriji i praktyky. Do 10-ji richnyci nezalezhnosti Ukrajiny. Kyjiv: In-t derzhavy i prava im. V.M. Korecjkogho NAN Ukrajiny, pp. 328-352 [in Ukrainian].

14. Kolodij A.M., Olijnyk A.Yu. (2003) Prava ljudyny i ghromadjanyna [Human and citizen rights]: navch. posib. Kyjiv: Jurinkom Inter [in Ukrainian].

15. Olijnyk A.Yu. (2008) Konstytucijno-pravovyj mekhanizm zabezpechennja osnovnykh svobod ljudyny i ghromadjanyna v Ukrajini [The constitutional and legal mechanism for ensuring the fundamental freedoms of man and citizen in Ukraine]: monoghrafija. Kyjiv: Alerta; KNT; Centr navchaljnoji literatury [in Ukrainian].

16. Bessonova M., Birjukov O., Bondaruk S. (ed.) (2002) Osnovy demokratiji [Fundamentals of democracy]: navch. posib. dlja stud. vyshh. navch. zakl. Kyjiv: Aj Bi [in Ukrainian].

17. Zavorotchenko T. (2002) Systema konstytucijno-pravovykh gharantij i svobod ljudyny i ghromadjanyna v Ukrajini [The system of constitutional legal guarantees and freedoms of human and citizen in Ukraine]. Pravo Ukrajiny, no. 5, pp. 110-115 [in Ukrainian].

18. Bobrova N.A. (1984) Garantii realizatsii gosudarstvenno-pravovykh norm [Guarantees of implementation of state legal norms]. Voronezh: Izd-vo Voronezh. un-ta [in Russian].

19. Poghorilko V.F. (1997) Osnovy konstytucijnogho ladu Ukrajiny [Fundamentals of the constitutional system of Ukraine]. Kyjiv: In Jure [in Ukrainian].

20. Skobelkin V.N. (1969) Yuridicheskie garantii trudovykh prav rabochikh i sluzhashchikh [Legal guarantees of labour rights of workers and employees]. Moskva: Nauka [in Russian]. 
21. Bobrova N.A., Zrazhevskaya T.D. Otvetstvennost' v sisteme garantiy konstitutsionnykh norm (gosudarstvenno-pravovye aspekty) [Responsibility in the system of guarantees of constitutional norms (state and legal aspects)]. Voronezh: Izd-vo Voronezh. un-ta, 1985 [in Russian].

22. Todyky Yu.M., Zhuravsjkogho V.S. (2002) Konstytucijne pravo Ukrajiny [Constitutional Law of Ukraine]: pidruchnyk. Kyjiv: In Jure [in Ukrainian].

23. Poghorilko V.F. (1999) Zaghaljni zasady konstytucijnogho ladu Ukrajiny [General principles of the constitutional order of Ukraine] // Konstytucijne pravo Ukrajiny [Constitutional Law of Ukraine]: pidruchnyk / za red. V.Ya. Tacija, V.F. Poghorilka, Yu.M. Todyky. Kyjiv: Ukrajinsjkyj centr pravnychykh studij, pp. 63-103 [in Ukrainian].

24. Shymin Yu.V. (2003) Systema gharantij konstytucijnogho ladu: aktualjni pytannja teoriji i praktyky [The system of guarantees of the constitutional order: current questions of theory and practice]. Bjuletenj Ministerstva justyciji Ukrajiny, no. 11, pp. 86-96 [in Ukrainian].

25. Savchyn M. (1999) Konstytucijnyj Sud Ukrajiny u mekhanizmi gharantuvannja prav i svobod ljudyny [The Constitutional Court of Ukraine in the mechanism of guaranteeing human rights and freedoms]. Pravo Ukrajiny, no. 4, pp. 35-38 [in Ukrainian].

Information about the author:

Larysa Nalyvaiko,

Doctor of Law, Professor,

Honored Lawyer of Ukraine, Vice-Rector, Dnipropetrovsk State University of Internal Affairs

26, Gagarina Ave, Dnipro, Ukraine

ORCID ID: orcid.org/0000-0002-7696-4223 


\section{RISK AS A MENTAL ELEMENT OF CIVIL LIABILITY OF POLICE OFFICERS IN UKRAINE}

\section{Olha Panchenko}

\section{INTRODUCTION}

Risk is one of the least studied concepts in legal science. For example, in criminal law, risk is investigated within the institution of circumstances that exclude criminality of an act (Section VIII of the Criminal Code of Ukraine) ${ }^{1}$. Thus, the actions of a person, who caused harm to legitimate interests in the conditions of a justified risk in order to achieve socially useful purpose, are recognized as lawful, and the person who caused harm under such conditions is not held criminally liable.

The problem for jurisprudence lies not in the mere fact of the existence of risky situations, but in the determination of criteria for the distinction between lawful and unlawful risk. In the theory of criminal law, within which the issue of risk was given special consideration, the following types of justifiable risk are defined: industrial, economic, professional, medical or technical, medical, pedagogical, sports, creative, administrative, risk in law enforcement, scientific experiment, etc. It appears from the foregoing that the problem of the risk cannot be solved within the criminal or any other area of law. It is complex, intersectoral problem.

The scientists summarize the factors that have actualized the problem of risk in Ukraine: 1) the rapid development of social and political relations in Ukraine encouraged the emergence of new relations in society; 2) the development of international relations at all levels is characterized by instability and danger both for the sovereignty of the State directly and for the world as a whole; 3 ) the role of Ukraine in certain international processes is of an exceptional nature, arising from its geographical position, natural, human, economic potential, etc. It is obvious that risk covers all aspects of human life. This category is related to production, creativity, recreation, sports, scientific and technological progress, etc. Risk is an integral part of many professional activities, particularly of law enforcement activities. Initiative, innovations are not possible without risk. The term "initiative" has two meanings: 1) the first step in any case, an act; 2) the ability to come up with new ideas, suggestions; ability to start any business independently; persistence, energy,

${ }^{1}$ Kryminaljnyj kodeks Ukrajiny. Stanom na 18 zhovtnja 2019 r. [Criminal Code of Ukraine: as of October 18, 2019]. Kyiv: Alerta. (in Ukrainian). 
entrepreneurship. Therefore, it is natural that the concept of risk is actively used in various fields of knowledge - not only in law, but also in economics, management, medicine, sports, and psychology ${ }^{2}$.

Risk is a multidimensional category, which is reflected in many rules of civil law, but it is revealed variously, using different terminology. For example, the Civil Code of Ukraine ${ }^{3}$ refers to the risk of accidental destruction and accidental damage to property (Art. 323 of the Civil Code of Ukraine), the risk of accidental destruction or accidental damage to the collateral (Article 580 of the Civil Code of Ukraine), the risk of accidental destruction or accidental damage to an item (Article 594 of the Civil Code of Ukraine), the risk of accidental destruction or accidental damage to the goods (Article 668 of the Civil Code of Ukraine), etc. Articles 924 and 947 of the Civil Code of Ukraine provide a somewhat opposite wording of the category under consideration - mainly the risk of "loss, deficiency, spoilage or damage". And this, obviously, does not limit the use of the term in civil law.

Under this article we will consider risk as a mental element of the civil responsibility of police officers, since the activities of police officers is precisely risky, and therefore in case of harm under justified risk, a person should be exempt from any kind of legal liability.

\section{Risk as a mental element of liability without fault}

In accordance with the provisions of Art. 1176, Part 1 of the Civil Code of Ukraine the injury caused by illegal actions of bodies of preliminary investigation, public prosecution and trial should be entirely compensate by the state regardless of fault of officials.

Traditionally, the concept of fault in domestic civil law coincides with the concept of fault in criminal law. Fault is the mental attitude of a person to his or her actions (unlawful behavior) and their result (breach of contract, harm, unjustified enrichment), the legal content of which is the desire or unwillingness of the occurrence of a wrongful result, the possibility or impossibility of predicting this result and its avoidance. Intent and negligence have traditionally been considered forms of guilt ${ }^{4}$.

As a general rule, fault is a necessary component of a civil offense, which requires the application of civil liability. According to of Art. 614, Part 1 of the Civil Code of Ukraine, the person who breached the obligation is

${ }^{2}$ Bondarchuk V.V. (2013). Ryzyk jak pravova kateghorija [Risk as a legal category]. Journal of Kyiv University of Law, no. 2. pp. 312-315.

${ }^{3}$ Cyviljnyj kodeks Ukrajiny: stanom na 30 veresnja 2018 r. [Civil Code of Ukraine: as of September 30, 2018]. Kharkiv: Law. (in Ukrainian).

${ }^{4}$ Dmitrieva O.V. (1997). Otvetstvennost bez viny v grazhdanskom prave [Liability without fault in civil law]. Voronezh: Ministry of Internal Affairs of the Russian Federation (in Russian). 
responsible in case of his (her) fault (intent or negligence), unless otherwise stipulated by the contract or law. Therefore, civil law presumes the fault of a person, that is, a person is guilty until he or she proves that he or she has taken all the measures necessary for the proper fulfillment of the obligation. This rule is confirmed by the provisions of Art. 614, Part 2 and Art. 1166, Part 2 of the Civil Code of Ukraine.

Liability without fault is an exception and applies only in cases expressly provided by law. Instead, I.S. Kanzafarova argues that in many cases civil law does not require the presence of all the elements of the crime. According to her opinion, the legal structure of the offense is alien to civil law, and the artificial spread of the criminal doctrine of the crime into the civil sphere has not only caused significant damage to the investigation of civil liability issues, but also led to the fact that the fundamental line between public and private law was violated ${ }^{5}$.

V.V. Parykusha, who disagrees with the views of those scientists, who do not consider innocent liability as civil one, is of the same opinion. Civil liability including liability without fault performs a compensatory function, unlike criminal liability, which performs punitive and corrective function and is reasonably linked to fault. It is important not to punish but to compensate the victim in full for civil liability, so in some cases fault has no legal value in bringing the offender to civil liability. The main thing is that there is harm and violated subjective rights of a person, which must be restored at any cost, even at the expense of the offender, though not innocent. Thus, liability without such an element of civil offense as fault is possible and it is quite normal for civil law, given the peculiarities of its functions ${ }^{6}$.

The justification of liability without fault in civil science was carried out in two directions. The first one was related to the search for objective reasons for the legislative assumption of no-fault liability, and the second one was the search for the subjective condition of such liability. Within the first direction of justification of liability without fault, the following theories were posed: justice; legal insurance; professional risk, which is now called "objective risk" theory; procedural benefits for the victim (procedural simplification); organizational and technical prevention and others ${ }^{7}$. However, as K. Adler correctly pointed out,

\footnotetext{
${ }^{5}$ Kanzafarova I.S. (2007). Teoretychni osnovy cyviljno-pravovoji vidpovidaljnosti v Ukrajini [Theoretical Foundations of Civil Liability in Ukraine] (Doctoral Thesis), Kiev: Institute of State and Law. V.M. Koretsky National Academy of Sciences of Ukraine.

${ }^{6}$ Parikusha V.V. (2010). Problemni aspekty cyviljno-pravovoji vidpovidaljnosti bez vyny [Problematic aspects of civil liability without fault]. Bulletin of the High Council of Justice, no. 2, 66-74.

${ }^{7}$ Dmitrieva O.V. (1997). Otvetstvennost bez viny v grazhdanskom prave [Liability without fault in civil law (in Russian).]. Voronezh: Ministry of Internal Affairs of the Russian Federation (in Russian).
} 
"Whatever liability (for the fault or no-fault) is enshrined in the law, it may turn out that the innocent will suffer in any particular case", that is, will be liable or compensate for accidentally caused damage.

The representatives of the second direction believe that the absence of fault in the attribution of no-fault liability does not mean that there is no subjective condition of civil liability in this situation. They argue that such condition is the risk of the offender.

What is risk? According to the definition given in the Great Interpretive Dictionary of Modern Ukrainian, "risk is the conscious possibility of danger, courageous, proactive action, action with the prospect of success, positive result; the possibility of loss or failure in any case" ${ }^{9}$. However, this definition is generalized and can be used in all spheres of society. To determine the legal nature of the risk, let's consider the views of the leading civilian scientists on this category.

According to $\mathrm{Yu}$.V. Baulin, risk is an objective state of danger of causing harm, in which it is not known whether this harm will occur or not ${ }^{10}$.

V.V. Baburin believes that risk is the conscious use of an opportunity to achieve the desired result by dangerous act or omission. Risk in its socio-legal significance is an important way of removing social and legal uncertainty, which causes tension in social relations ${ }^{11}$.

S.N. Bratus defines risk as conscious assumption of potential random events when operating a source of increased risk that entail negative consequences for others, and accepting these consequences by the owner of the source of increased risk ${ }^{12}$.

V.V. Yakovlev, for his part, argues that risk is possible only if a probable process is considered, and the decision-maker has the right to choose one or the other course of action or to refuse any of them ${ }^{13}$.

${ }^{8}$ Adler K. (1914). Otvetstvennost bez viny v grazhdanskom i ugolovnom prave [Liability without fault in civil and criminal law]. St-Petersburg: publishing house Law book store named after N.K. Martynov (in Russian).

${ }^{9}$ Busel V.T. (2005). Velykyj tlumachnyj slovnyk suchasnoji ukrajinsjkoji movy [The Great Explanatory Dictionary of Modern Ukrainian]. Kyiv; Irpin: Perun. (in Ukrainian).

${ }^{10}$ Baulin Y.V. (1989). K voprosu o professionalnom i khozyaystvennom riske $\mathrm{v}$ proekte Osnov ugolovnogo zakonodatelstva [To the issue of professional and economic risk in the Draft Fundamentals of the Criminal Law. State of Law, issue 1, pp. 226-229.

${ }^{11}$ Baburin V.V. (2009). Risk kak osnovanie differentsiatsii ugolovnoy otvetstvennosti [Risk as a basis for the differentiation of criminal responsibility] (Doctoral Thesis), Omsk: The Ministry of the Interior of the Russian Federation, Omsk Academy.

${ }^{12}$ Bratus S.N. (1973). Spornye voprosy teorii yuridicheskoy otvetstvennosti [Controversial issues of the theory of legal liability]. Soviet State and Law, no. 4, pp. 27-35.

${ }^{13}$ Mamaykin V.P., Shcherbakov V.N., Yakovlev V.V. (1996). Problema otsenki riska [The problem of risk assessment]. Life and Safety, no 4. pp. 103-108. 
V.A. Oygenzikht assesses risk from the standpoint of psychology and provides the following definition of the concept: "risk is the mental attitude of the actors to the result of their own actions or to the behavior of others, as well as the possible result of an objective case and accidentally impossible actions, expressed in the conscious assumption of negative, including irreversible, property consequences. The presumption of adverse effects from the possible result of such actions (events) means the assumption of these consequences or their imposition on the subjects who are "at risk" in this case ${ }^{14}$.

This is exactly how the police officers perceive the result of the performance of their duties. They carry out functions with a higher degree of social responsibility, which are associated with a significant level of danger or conditions of extreme need, and use objects that are sources of high risk (vehicles, weapons, service dogs, etc.). In such circumstances, the possibility of causing damage to life, health or property of a person cannot be completely excluded.

On the basis of the foregoing, we remain of the view of those scholars who believe that responsibility for risk in civil law has every reason to be responsibility in its own sense. Therefore, let's take a closer look at the views of those scientists who are adherents of the concept of subjective risk. Subjective risk theory has received the greatest development in the scientific works of V.A. Oygenzikht, S.N. Bratus and Yu.G. Basin.

The representatives of this theory believe that the absence of fault in the attribution of liability without fault does not mean that in this situation there is no mental element of civil liability. In their view, the mental element is the risk of the offender. Risk is, like fault and innocence, a mental attitude of the subject to his (her) behavior, which, however, is different from both fault and innocence. Thus, V.A. Oygenzikht explains that "risk differs from innocence by the fact that innocence always precludes any prediction and even any possibility of predicting the harmful consequences by the subject of his (her) behavior, and the conscious assumption inherent in the risk involves the prediction, at least not absolute, but in the form of an abstract opportunities. The fault implies the undoubted anticipation of the consequences or the possibility of such prediction, while assuming the same risk leaves a certain percentage of doubt, bearing in mind only a certain probability, but not an absolute necessity of the occurrence of the harmful consequences"15.

According to S.N. Bratus, the subjective basis for the emergence of a legal obligation to compensate for the harm and liability arising from the failure to

14 Oygenzikht V.A. (1971). Kategoriya riska v sovetskom grazhdanskom prave [Risk in Soviet Civil Law]. Jurisprudence, no. 5, pp. 64-70.

${ }^{15}$ Oygenzikht V.A. (1972). Problema riska v grazhdanskom prave [The problem of risk in civil law]. Dushanbe: Irfon. (in Russian). 
fulfill this obligation is the risk as a presumption of "probable", accidental conditions that cause adverse consequences for others ${ }^{16}$.

It is obvious that not all scientists agree with the representatives of this theory. Thus, the subjective concept of risk is criticized by T.I. Illarionova, who, in particular, points out that according to the rules of law risk is associated with chance, which, in the author's opinion, excludes mental attitude ${ }^{17}$. However, this statement is somewhat outdated, since not all the rules of the current Civil Code of Ukraine that contain the term "risk" use solely its objective understanding, linking the risk with chance, and secondly, thanks to the norms of the Civil Code of Ukraine connected with the concept of risk, the party to civil relations, in some cases, still has the choice to take (or not to take) all the necessary measures to reduce the negative consequences of the realization of such risk.

F.A. Vyacheslavov criticizes the subjective concept of risk as well, stating that such an understanding of risk goes against the traditions of both Roman and national civil law, as according to the classical interpretation of this category risk is considered an objective onset of certain consequences in the form of threat. The scientist considers the reason for the emergence of the subjective concept of risk in the fact that the understanding of this category was not based on the universal definition of risk as a possibility of certain harm, but on the usual day-to-day expression "to take risk"18.

It is difficult to agree with such a view of a scientist. The risk is possible only when the subject is engaged in some particular kind of activity (carries out scientific tests, saves the life of hostages, operates of a source of high risk). There is no risk in the situation, in which the subject does not take actions related to the occurrence of unfavorable consequences for him. The criterion of the individual's mental attitude to his (her) own actions (if the risk is directly related to the activity of the party to civil relations), or to certain circumstances independent of the will of the individual (e. g., actions of other persons) comes to the fore according to this concept. The threat of certain adverse effects is not considered a risk by itself, since on case of such a threat an individual must make his (her) own choice of behavior, within a certain alternative, and therefore makes a choice between several possible options for such behavior, evaluating them for expediency and effectiveness.

${ }^{16}$ Bratus S.N. (1986). Yuridicheskaya otvetstvennost i zakonnost [Legal responsibility and lawfulness]. Volume 1. Moskow: Science. (in Russian).

${ }^{17}$ Maidanyk R.A. (2007). Anomaliji v cyviljnomu pravi Ukrajiny [Anomalies in the Civil Law of Ukraine]. Kyiv: Justinian. (in Ukrainian).

${ }^{18}$ Vyacheslavov F.A. (2007). Raspredelenie riskov: ponyatie i znachenie v grazhdanskom prave [Risk allocation: the concept and meaning in civil law]. Bulletin of the Moscow University. M.V. Lomonosov, Series 11: Law, no. 4, pp. 74-91. 
We support the notion that liability without fault is based on the acceptance of risk and agree with the statement that the using the term "liability without fault" is incorrect, it is more correct to speak about liability for risk, since the real condition for imposing liability is the effect of an incident as a flip side of legal risk"19. This statement is well founded, but concerns only tort liability. Unlike tort liaility, contractual liability arises within preexisting legal relationships, which clearly define the debtor and creditor, their rights and obligations. The debtor, by entering into an agreement, compares or at least has to compare his capabilities with the content of the obligations assumed; he is aware of the nature of the obligations assumed and specifically provides for the possibility of liability in case of their breach. In this regard, the onset of contractual liability in the vast majority of cases is devoid of the factor of suddenness, and therefore risk ${ }^{20}$.

\section{Risk in the activities of police officers}

Therefore, on the basis of the stated above, we have succeeded in proving that police officers are liable exectly for risk when performing their duties. This is due to the fact that police officers are sometimes forced to make vital decisions in stressful situations, with neither time nor possibility to evaluate all the circumstances of the case for taking adequate measures to respond to it. In case of non-compliency of the measures taken to the circumstances of the case, police officers hold liable for the results. In this regard, most of them are constantly in a stress, which accordingly affects their mental state and the decisions they make.

The very work of police officers on the performance of duties imposed on them by law is a priori risky, since it may lead to a violation of the subjective rights and freedoms of a person. Risk involves the admission of adverse events and the willingness of the subject to take responsibility for them. This activity, as it was already noted, is the performance of the corresponding duties by police oficers.

Indeed, according to Art. 23 of the Law of Ukraine "On the National Police" (hereinafter - the Law) ${ }^{21}$ police officers in accordance with the tasks entrusted to them: 1) carry out preventive activities aimed at preventing the commission of offenses; 2) determine the causes and conditions contributing

${ }^{19}$ Ioffe O.S. (1975). Obyazatelnoe pravo [Law of Obligations]. Moskow: Legal Literature. (in Russian).

${ }^{20}$ Petrycyn N.T. (2012). Teoretyko-pravovyj analiz osoblyvostej cyviljnoji vidpovidaljnosti za ryzyk [Theoretical and legal analysis of the features of civil liability for risk]. Actual problems of State and Law. no. 64. pp. 325-330.

${ }^{21}$ Zakon Ukrajiny "Pro Nacionaljnu policiju" stanom na 05 ljutogho $2016 \mathrm{r}$. [Law of Ukraine on the National Police: current legislation as of February 05, 2016]. Kyiv: Alerta. (in Ukrainian). 
to the commission of criminal and administrative offenses, and take measures within their competence to eliminate them; 3 ) take measures to detect criminal and administrative offenses; terminate detected criminal and administrative offenses; 4) take measures aimed at eliminating threats to life and health of individuals and public safety resulting from the commission of a criminal, administrative offense; 5) promptly respond to allegations and reports on criminal, administrative offenses; 6) conduct pre-trial investigation of criminal offenses within the defined jurisdiction; 7) search for persons hiding from the bodies of pre-trial investigation, investigating judge, court, evading criminal punishment, missing persons, and other persons in cases prescribed by law; 8 ) conduct proceedings in cases of administrative offenses, make decisions on the use of administrative penalties and ensure their enforcement in cases specified by law; 9) deliver detained persons, suspected of committing a criminal offense and persons who committed an administrative offense in cases and in the order, prescribed by; 10) take measures to ensure public safety and order in the streets, squares, parks, squares, stadiums, railway stations, airports, sea and river ports, other public places, etc.

It is clear enough that when exercising such powers, police officers may encounter resistance from certain persons. To counter this, police officers have the right to use police measures that are acts or complex of acts of preventive or coercive nature that restrict certain human rights and freedoms and are used by police officers under the law to enforce the powers vested in the police (Article 29 of the Law).

Preventive police measures are: 1) verification of identity documents; 2) interviewing a person; 3) cursory inspection; 4) halt of the vehicle; 5) the requirement to leave some place and restrict access to the designated area; 6) restricting the movement of a person, vehicle or actual possession of the thing; 7) penetration into the dwelling or other possession of a person; 8 ) verification of compliance with the requirements of the permit system of law enforcement agencies; 9) the use of technical instruments and equipment with the functions of photo and video recording; 10) verification of compliance with the statutory restrictions on persons under administrative supervision and other categories of persons; 11) police care.

When exercising their authority police officers are empowered to apply the following coercive measures: 1) physical influence (force); 2) the use of special means; 3 ) the use of firearms. The rules and conditions for implication of police coercion measures are regulated by Art. Art. 42-46 of the Law.

The objectivity of risk when using police measures is obvious, since life and health of others, as well as their ability to exercise the rights and freedoms provided for in the Constitution and laws of Ukraine may depend on the actions of police officers. 
The subjectivity of risk is expressed in the right of police officers to make their own decisions on the implementation of the appropriate preventive measure. Indeed, Art. 43, Part 3 enshrines that the type and intensity of coercive measures are determined taking into account the specificity of the situation, the nature of the offense and the individual characteristics of the person who committed the offense.

Besides, in order for the risk to be justified, the applied police coercive measure must meet certain requirements, namely: 1) be lawful - a police officer is prohibited to apply any measures other than those determined by the laws of Ukraine; 2) be necessary - that is, for the performance of police powers it is impossible to apply another measure or its implementation will be ineffective, as well as such measure should caus the least harm to both the addressee of the measure and other persons; 3) be proportional - the damage caused to human rights or freedoms, protected by law by the law, or to the interests of society or the State, must not exceed the good for the protection of which it was applied, or the created threat of harm; 4) effective - the application of a coercive measure ensures exercise of the police powers.

The greatest risk, as we understand it, is related to the use of weapons. Indeed, the use of firearms almost always occurs in a stressful situation, in which it is very difficult to determine the nature and extent of the threat of an attack. In other words, it is quite problematic for a police officer to evaluate the possible consequences of a socially dangerous act, as well as the proportionality of the harm caused to the offender as a result of the use of a weapon, with the harm that may result from the unlawful act of the latter.

Therefore it is very important that the legal evaluation of the actions of the police officers be carried out impartially, without an accusatory bias, taking into account all the circumstances of the case. As I.V . Dymon correctly points out, "the use of firearms to kill is a complex psychological process for a police officer, since the activity of a police officer in each individual situation is formed on the motivational and value characteristics of the police officer's personality, his or her cultural and religious orientations, and, on individual features of social perception"22.

In the USA, for comparison, where police officers are forced to deal with dangerous, aggressive and armed crime in the same way as in Ukraine, in the majority of cases, such actions by US cops are considered legitimate, even if it has led to fatal consequences. For US police, the use of weapons against offenders is a common practice. For example, in the last 15 years, 179

22 Dymon I.V. (2014). Zastosuvannja voghnepaljnoji zbroji jak krajnjogho zakhodu administratyvnogho prypynennja [The use of firearms as the last resort of administrative termination]. Our law, no. 6, pp. 28-33. 
incidents involving the use of firearms have occurred in the jurisdiction of the New York Police Department. Only in three of these cases police officers were formally charged. And only one case case resulted in judicial sentence ${ }^{23}$.

Risk in the profession of police officer can be defined as the presence of the possibility of adverse conditions and the effects of adverse factors in professional situations, which can lead to inconclusive results with the mandatory presence of adverse effects for the police officer ${ }^{24}$.

P. Kabanov, when considering the problems of risk in the investigation of crimes commited by the representatives of law enforcement agencies, notes that the measures aimed at crime solving and investigation is characterized by decision-making in the absence of information.

The consequences of risk can be divided into two types: tactical and procedural.

Tactical consequences include the weakening of the evidential force of previously obtained information, the loss of tactical advantage, and in general lead to the complication of the investigative situation, combined with additional costs to neutralize the negative effects of risk ${ }^{25}$.

For example, in accordance with the provisions of Art. 223 of the Criminal Code of Ukraine no one has the right to penetrate into the dwelling or other possession of a person for any purpose, except with the voluntary consent of the person who owns it or on the basis of the order of the investigating judge solely in cases prescribed by law. An investigator, a prosecutor has the right to enter a dwelling or other possession of a person prior to order of an investigating judge only in urgent cases connected with saving human life and property or directly prosecuting persons suspected of committing a crime. In such a case, a prosecutor, an investigator in agreement with the prosecutor, is obliged to submit a request for a seach to an investigating judge after such actions have been taken. The investigating judge considers such a request in accordance with the requirements of Art. 234 of this Code, verifying, among other things, whether there were really grounds for entering into the dwelling or other possession of a person without the order of an investigating judge. If the prosecutor refuses to agree to the request of the investigator for the search or the investigating judge refuses to satisfy the request for search, the

23 Lukjanchuk S. (2016). Chomu policija SShA ne vaghajuchysj striljaje u pravoporushnykiv? [Why does the US police not hesitant to shoot offenders?] [Electronic resource]. Retrieved November 10, 2019 from http://cripo.com.ua/? sect_id $=1 \&$ aid $=208566$.

${ }^{24}$ Osintseva A.V. (2015). Viktimologicheskiy aspekt professionalnoy deyatelnosti sotrudnika politsii $\mathrm{v}$ kontekste professionalnykh riskov [Victimological aspect of professional activity of police officer in the context of professional risks]. Victimology, no. 4 (6), pp. 19-25.

${ }^{25}$ Kabanov P. (1989). Risk pri rassledovanii prestupleniy [Crime Investigation Risk]. Social legitimacy, no. 2. pp. 56-58. 
evidence established as a result of such search is inadmissible and the information obtained should be destroyed. In this situation there is a manifestation of risk. The purpose for conducting preliminary investigation is socially useful: it is to collect evidence of a socially dangerous act and the fault of a person in its commission. The mode of action in a situation, which is urgent and cannot be postponed may be chosen by the representative of the law enforcement agency on his (her) own. For example, a person involved in a crime has locked up in an apartment and an investigator believes that he (she) is trying to hide the traces of the crime. There are two options for an investigator: the first one is to contact an investigating judge for permission to search a dwelling; the second one - to conduct a search without obtaining such a permission. In doing so there is a risk in both options. In the first case, it is likely that during the time required to obtain a court permission, the suspect will conceal or destroy the traces of a crime, and the investigator will not be able to prove his (her) involvement in the crime. In the second case the court may find the actions of an investigator illegal and unsubstantiated, and in this case the evidence obtained during their conduct will lose probative value. Therefore, both the first course of action and the second one involve the risk of loss of evidence in the case.

To procedural (social and legal) consequences of the risk P. Kabanov includes restrictions on the rights of citizens, violation of their personal integrity, defamation of law enforcement agencies ${ }^{26}$.

Particularly problematic is the issue of the actions of law enforcement officers in extreme conditions. Extreme conditions mean circumstances of high degree of danger caused by phenomena of natural, biological and social nature and require from law enforcement agencies special organizational and legal measures and their resourcing. This set of factors that dramatically violate the normal conditions of life of the population, public safety and the rule of law significantly complicates law enforcement activities.

The sources that create extreme conditions can be divided into three groups: 1) phenomena associated with the actions of the natural forces of nature; 2) social phenomena related to human behavior; 3) phenomena caused by reasons of technical nature ${ }^{27}$.

Considering the second group of factors, it should be noted that the general condition is the unlawfulness of conduct, violation of public order,

${ }^{26}$ Kabanov P. (1989). Risk pri rassledovanii prestupleniy [Crime Investigation Risk]. Social legitimacy, no. 2. pp. 56-58.

27 Maydykov A.F. (1989). Predmet, zadachi i sistema kursa "Upravlenie organami vnutrennikh del $\mathrm{v}$ ekstremal'nykh usloviyakh" [Subject, tasks and system of the course "Management of law-enforcement agencies in extreme conditions"]. Moskow: Academy of the Ministry of Internal Affairs of the USSR. 
committing socially dangerous actions, etc. (for example, mass riots, hostagetaking, escape from a place of detention and custody). The cessation and elimination of these phenomena present the greatest difficulties for the law enforcement agencies, as they can cause death, serious harm in case of failure to take timely decisions and sufficient measures.

Extreme conditions change the usual methods of police officers activities. This is due to the situation of choice between the expediency and legality of the actions taken and the lack of the necessary legal regulation of the activities of police officers in such conditions.

\section{CONCLUSIONS}

Based on the stated above, we can conclude that risk as a subjective condition of civil liability of police officers is a multifaceted category that affects not only the norms of civil law, but also the norms of many other branches of law, especially criminal law. Risk is the necessary element of the activities of the National Police of Ukraine, as police officers are constantly forced to make decisions in precarious conditions and unusual situations when performing the duties on protection of human rights and freedoms, combating crime, maintaining public safety and order assigned to them by the law. In this regard, the majority of police officers are constantly under stress, which affects both their mental state and the decisions they make.

As A.P. Algin correctly points out, the risk causes the existence of a "situation of risk" in the activities of police officers, provided the following conditions are met: 1) the presence of uncertainty - it is difficult to predict the development of the situation; the probability of occurrence of negative consequences is quite high if the situation is not affected; 2) the need to choose an alternative (including the refusal to choose) - the behavior of police officer is governed by applicable law, but in the situation the line between what is allowed and necessary is rather blurred; 3 ) the opportunity to evaluate the possibility of implementing of selected alternatives - as a correlation of the possibility of occurrence of positive and negative results, depending on the decision ${ }^{28}$.

Therefore, in our opinion, risk as a mental element of civil liability of police officers is the policemen's awareness of the possibility of adverse consequences in the process of performance of the tasks to ensure the protection of human rights and freedoms, counteract crime, maintain public safety and order, assigned to them by law.

${ }^{28}$ Algin A.P. (1989). Risk i ego rol' v obshchestvennoy zhizni [Risk and its role in public life]. Moskow: Thought. (in Russian). 


\section{SUMMARY}

The article deals with the problem of risk as a mental element of civil liability of police officers. An accent is placed on the complexity of the problem of risk, its cross-sectoral nature. The article examines scientific approaches to the definition of the concept of "risk", studies the objective and subjective theories of risk. The author takes the view of those scholars who believe that responsibility for risk in civil law has every reasonable basis to be responsibility in its own sense, and argues that the performance of police duties is always linked to the risk, which they are conscious of. The article examines the objectivity and subjectivity of risk, as well as the criteria for justification of risk in police activity. Based on the study of the relevant legislation and police practice, specific examples of the calculated risk in the activities of police officers are provided. It is noted that the consequences of risk in police activities can be divided into two types: tactical and procedural; it is considered what these consequences are. Attention is drawn to the fact that the issue of police officers actions in extreme conditions is particularly problematic. The author's definition of risk as a subjective condition of civil liability of police is given. It is emphasized that the legal evaluation of the actions of the police officers be carried out impartially, without an accusatory bias, taking into account all the circumstances of the case.

\section{REFERENCES}

1. Adler K. (1914). Otvetstvennost bez viny $v$ grazhdanskom i ugolovnom prave [Liability without fault in civil and criminal law]. St-Petersburg: publishing house Law book store named after N.K. Martynov (in Russian).

2. Algin A.P. (1989). Risk i ego rol' v obshchestvennoy zhizni [Risk and its role in public life]. Moskow: Thought. (in Russian).Kryminaljnyj kodeks Ukrajiny. Stanom na 18 zhovtnja 2019 r. [Criminal Code of Ukraine: as of October 18, 2019]. Kyiv: Alerta. (in Ukrainian).

3. Baburin V.V. (2009). Risk kak osnovanie differentsiatsii ugolovnoy otvetstvennosti [Risk as a basis for the differentiation of criminal responsibility] (Doctoral Thesis), Omsk: The Ministry of the Interior of the Russian Federation, Omsk Academy.

4. Baulin Y.V. (1989). K voprosu o professionalnom i khozyaystvennom riske $\mathrm{v}$ proekte Osnov ugolovnogo zakonodatelstva [To the issue of professional and economic risk in the Draft Fundamentals of the Criminal Law. State of Law, issue 1, pp. 226-229.

5. Bondarchuk V.V. (2013). Ryzyk jak pravova kateghorija [Risk as a legal category]. Journal of Kyiv University of Law, no. 2. pp. 312-315. 
6. Bratus S.N. (1973). Spornye voprosy teorii yuridicheskoy otvetstvennosti [Controversial issues of the theory of legal liability]. Soviet State and Law, no. 4, pp. 27-35.

7. Bratus S.N. (1986). Yuridicheskaya otvetstvennost i zakonnost [Legal responsibility and lawfulness]. Volume 1. Moskow: Science. (in Russian).

8. Busel V.T. (2005). Velykyj tlumachnyj slovnyk suchasnoji ukrajinsjkoji movy [The Great Explanatory Dictionary of Modern Ukrainian]. Kyiv; Irpin: Perun. (in Ukrainian).

9. Cyviljnyj kodeks Ukrajiny: stanom na 30 veresnja 2018 r. [Civil Code of Ukraine: as of September 30, 2018]. Kharkiv: Law. (in Ukrainian).

10. Dmitrieva O.V. (1997). Otvetstvennost bez viny v grazhdanskom prave [Liability without fault in civil law]. Voronezh: Ministry of Internal Affairs of the Russian Federation (in Russian).

11. Dymon I.V. (2014). Zastosuvannja voghnepaljnoji zbroji jak krajnjogho zakhodu administratyvnogho prypynennja [The use of firearms as the last resort of administrative termination]. Our law, no. 6, pp. 28-33.

12. Ioffe O.S. (1975). Obyazatelnoe pravo [Law of Obligations]. Moskow: Legal Literature. (in Russian).

13. Kabanov P. (1989). Risk pri rassledovanii prestupleniy [Crime Investigation Risk]. Social legitimacy, no. 2. pp. 56-58.

14. Kanzafarova I.S. (2007). Teoretychni osnovy cyviljno-pravovoji vidpovidaljnosti v Ukrajini [Theoretical Foundations of Civil Liability in Ukraine] (Doctoral Thesis), Kiev: Institute of State and Law. V.M. Koretsky National Academy of Sciences of Ukraine.

15. Lukjanchuk S. (2016). Chomu policija SShA ne vaghajuchysj striljaje $\mathrm{u}$ pravoporushnykiv? [Why does the US police not hesitant to shoot offenders?] [Electronic resource]. Retrieved November 10, 2019 from http://cripo.com.ua/?sect_id $=1 \&$ aid $=208566$.

16. Maidanyk R.A. (2007). Anomaliji v cyviljnomu pravi Ukrajiny [Anomalies in the Civil Law of Ukraine]. Kyiv: Justinian. (in Ukrainian).

17. Mamaykin V.P., Shcherbakov V.N., Yakovlev V.V. (1996). Problema otsenki riska [The problem of risk assessment]. Life and Safety, no 4. pp. 103-108.

18. Maydykov A.F. (1989). Predmet, zadachi i sistema kursa "Upravlenie organami vnutrennikh del v ekstremal'nykh usloviyakh" [Subject, tasks and system of the course "Management of law-enforcement agencies in extreme conditions"]. Moskow: Academy of the Ministry of Internal Affairs of the USSR.

19. Osintseva A.V. (2015). Viktimologicheskiy aspekt professionalnoy deyatelnosti sotrudnika politsii $\mathrm{v}$ kontekste professionalnykh riskov 
[Victimological aspect of professional activity of police officer in the context of professional risks]. Victimology, no. 4 (6), pp. 19-25.

20. Oygenzikht V.A. (1971). Kategoriya riska v sovetskom grazhdanskom prave [Risk in Soviet Civil Law]. Jurisprudence, no. 5, pp. 64-70.

21. Oygenzikht V.A. (1972). Problema riska v grazhdanskom prave [The problem of risk in civil law]. Dushanbe: Irfon. (in Russian).

22. Parikusha V.V. (2010). Problemni aspekty cyviljno-pravovoji vidpovidaljnosti bez vyny [Problematic aspects of civil liability without fault]. Bulletin of the High Council of Justice, no. 2, 66-74.

23. Petrycyn N.T. (2012). Teoretyko-pravovyj analiz osoblyvostej cyviljnoji vidpovidaljnosti za ryzyk [Theoretical and legal analysis of the features of civil liability for risk]. Actual problems of State and Law. no. 64. pp. 325-330.

24. Vyacheslavov F.A. (2007). Raspredelenie riskov: ponyatie i znachenie $\mathrm{v}$ grazhdanskom prave [Risk allocation: the concept and meaning in civil law]. Bulletin of the Moscow University. M.V. Lomonosov, Series 11: Law, no. 4, pp. 74-91.

25.Zakon Ukrajiny "Pro Nacionaljnu policiju" stanom na 05 ljutogho 2016 r. [Law of Ukraine on the National Police: current legislation as of February 05, 2016]. Kyiv: Alerta. (in Ukrainian).

\section{Information about the author: \\ Olha Panchenko, \\ $\mathrm{PhD}$ in Law,}

District Officer of Mirgorod Police Department

34, Jakova Usyka str., Mirgorod, 37600, Ukraine

ORCID ID: orcid.org/0000-0003-4365-0495 


\section{WAYS TO INTERPRET TAX LEGISLATION}

\section{Igor Samsin}

\section{INTRODUCTION}

An urgent need in Ukraine was to ensure the consistency of case law. Such unity is in the countries of the European Community and in the Anglo-Saxon legal system. This is due to the processes of globalization and prospects for European integration of Ukraine. The established and unique jurisprudence in these countries has been shaped for centuries. Ukraine should establish such practices in a short time.

It is possible, if it comes the realization that time intuitive, artistic, organoleptic, associative and irrational law passed. It is a rational law. The onset of this delayed time with the reason that, until recently, either in our country or in other countries are not carried out a thorough study on the interpretation of regulations. These studies gave us the opportunity to see the full range of logical and legal means, the use of which reveals the content of the provisions of legal acts in their system.

In general, all processes occurring in the field of law: law-making, lawenforcement and law-interpreting, because these processes are intellectual and designed to make their outcome accessible and understandable to everyone. Achieving this criterion is possible only if the fundamental principles of these processes will have a universal character of logical thinking.

Considering interpretation as an intellectual activity, A. Cherdantsev proceeded from the fact that this is the process of logical deduction and proving the truth of our knowledge about the content of the rules of law, in the course of which apply all the laws and techniques that are in the arsenal of $\operatorname{logic}{ }^{1}$. From this point of view, he indicated that all ways of interpretation are logical. However, the researcher singled out logical interpretation in the narrow sense, as a separate way of interpretation, understanding the interpretation in which the interpreter with the help of purely logical techniques operates the material of the most interpreted norm, without going beyond its boundaries, without resorting to other norms of law (logical transformation, the conclusion from the previous to the next, the conclusion from the opposite, the following from the concepts, the conclusions of the

\footnotetext{
${ }^{1}$ Cherdantsev A.F. (1972). Voprosy tolkovaniya sovetskogo prava [Interpretation issues of Soviet law]. (p. 79) Sverdlovsk [in Russian].
} 
degree, the derivation of norms from norms, analogy, bringing to the absurd and etc. $)^{2}$.

An important part in the interpretation issue is the approach to clarifying the meaning of the acts disclosed in certain rules and techniques, which in turn defines different ways of interpreting acts of tax law. In turn, these tools make it possible to see in legal acts all their legal content, which today the average lawyer sees less than fifty percent.

The established methods of elaboration of normative texts make it possible to constructively solve a number of problems that are solved unilaterally and unconstructively without this knowledge. These are the problems of correlation of natural and positivist legal thinking, judicial lawmaking, contra legem court decisions, algorithm of interpretation, application of the principles of law, especially the principle of the rule of law, the analogy of the law and law.

\section{Approaches to the classification of ways of interpreting acts of tax legislation}

One of the most important tools for regulating public relations is law. It acts as a regulator and a means of direct managerial influence. Norms of law encourage people to engage in active behavior, punish, prohibit, or allow specific actions. Norms of law are usually understood to be a formally binding rule of physical conduct, of a general nature, established or sanctioned by the state for the purpose of regulating public relations and provided with appropriate safeguards for its implementation ${ }^{3}$. From how state will is formulated in law, largely depends on the effectiveness of its implementation, its understanding of the performers, compliance with their actions to the requirements of law ${ }^{4}$.

The constitution and laws must be interpreted in accordance with certain rules. Only then can an adequate understanding and clarification of legal rules be relied upon ${ }^{5}$.

The purpose of clarifying the meaning of a rule is to interpret it as a process based on the application of methods and techniques that allow the formulation of a lawful (logical) rule.

\footnotetext{
${ }^{2}$ Cherdantsev A.F. (1972). Voprosy tolkovaniya sovetskogo prava [Interpretation issues of Soviet law] (p. 81) Sverdlovsk [in Russian].

${ }^{3}$ Shemshuchenko Yu.S. (Eds.) (2003). Jurydychna encyklopedija [Legal Encyclopedia] (Vols. 1-6) (Vol. 4). Kyiv: Ukrainska Encyklopediya [in Ukrainian].

${ }^{4}$ Alekseev S.S. (1999). Sotsial'naya tsennost' prava v sovetskom obshchestve [The social value of law in Soviet society]. Moscow: Yuridichtskaya Literatura [in Russian].

${ }^{5}$ Todyka Yu.M. (2001). Tlumachennja konstytuciji i zakoniv Ukrajiny: teorija i praktyka: monoghraf [Interpretation of the constitution and laws of Ukraine: theory and practice: monograph]. (p. 122) Kharkiv: Fakt [in Ukrainian].
} 
The method of interpretation in the literature refers to a set of homogeneous techniques and rules of interpretation ${ }^{6}$. Namely, according to S. Alekseev, the method of interpretation is a general concept, which also includes methods of interpretation. Indeed, the admission is a "specific cognitive action" that is realized within the limits of a particular mode of interpretation and obeys the laws and rules of this method.

The eminent jurist E. Vaskovskii the interpretation as such is generally defined through the techniques, indicating that the interpretation, or interpretation, is a set of techniques used in the creativity of people in order to understand its essence ${ }^{8}$.

Among the techniques of the interpretation are called comparison, analogy, the derivation of one knowledge from another. ${ }^{9}$ Special interpretation is also in isolation from the letter of the law or associative interpretation ${ }^{10}$.

Ukrainian scientists M. Kelman and O. Murashyn define a way of interpretation as a set of techniques and means that allow to find out the content of a rule of law and expressed the purpose in of their implementation ${ }^{11}$.

It is difficult to agree with the proposed definition, since the reference to "means" of interpretation means references to the logistical, intellectual factors that usually affect the interpretation process in each case, but do not form the basis of its methodology.

It is advisable to offer another definition of how to interpret tax legislation: it is a system of approaches to clarifying the content (meaning) of acts disclosed in specific rules and techniques, the application of which allows to establish a logical rule of tax law to overcome defective legal material with the purpose establishing the true value of the rule of law to be applied to the disputed case.

\footnotetext{
${ }^{6}$ Alekseeva S.S. (Ed.) (1987) Problemy teorii gosudarstva i prava [Problems of the theory of state and law]. (p. 397) Moscow: Yuridichtskaya Literatura [in Russian].

${ }^{7}$ Voplenko N.N. (1993). Tolkovanie prava. Obshchaya teoriya prava [The interpretation of law. General Theory of Law] kurs lektsiy, (p. 373). Nizhniy Novgorod [in Russian].

${ }^{8}$ Vas'kovskiy E.V. (1913). Rukovodstvo k tolkovaniyu i primeneniyu zakonov: dlya nachinayushchikh yuristov [Guide to the Interpretation and Application of Laws: For Beginners]. (p. 32) Moscow : Br. Bashmakovykh [in Russian].

${ }^{9}$ Voplenko N.N. (1993). Tolkovanie prava. Obshchaya teoriya prava [The interpretation of law. General Theory of Law] kurs lektsiy, (p. 373). Nizhniy Novgorod [in Russian].

${ }^{10}$ Rotanj V. (Ed.) (2008) Naukovo-praktychnyj komentar do cyviljnogho zakonodavstva Ukrajiny [Scientific and practical commentary on the civil legislation of Ukraine] (Vols. 1-4) Metodologhija tlumachennja normatyvno-pravovykh aktiv Ukrajiny [Methodology of interpretation of normative legal acts of Ukraine] (Vol. 3) (p. 328) Kyiv: Juryd. kn.; Sevastopolj: In-t juryd.doslidzhenj [in Ukrainian].

${ }^{11}$ Keljman M.S., Murashyn O.Gh. (2006). Zaghaljna teorija derzhavy i prava [General theory of state and law] Kyiv: Kondor [in Ukrainian].
} 
In connection with the outlined approach the interpretation methods are all epistemological means of the recognition. "Legal understanding recognizes the theoretical and practical importance of linguistic, textual (hermeneutical), structuralist, logical-analytical, legal-dogmatic directions, techniques and means of studying the problems of law" $" 12$.

In view of this, let us try to distinguish the characteristic features of the ways of interpreting the rules of law, to which we consider it appropriate to include the following:

1) ways of interpreting legal rules include techniques and rules for the interpretation of legal rules;

2) the ways in which legal rules are interpreted make it possible to comprehensively understand the content of a legal rule;

3) ways of interpreting legal norms contribute to the realization of law by defining the true content of the legal norm and bringing it to the attention of the subjects of law and subjects of law;

4) ways of interpretation of legal norms ensure the comprehensiveness and complexity of the interpretation of legal rules;

5) ways of interpretation of legal norms are implemented in the activities of the subjects of interpretation of law, the content of which is the internal mental process of establishing the content of the legal norm in the mind of the subject of interpretation of the rule of law;

6) the ways of interpreting legal norms determine the official or informal nature of the interpretation of legal norms;

7) ways of interpretation of legal norms are conditioned by the content of the legal norm and the professional level of the subjects of interpretation of the rule of law;

8) the ways of interpreting legal norms ensure the effectiveness of the interpretation of legal norms in general, which consists in providing a reasonable answer regarding the content of the will of the law-maker, which is enshrined in the legal norm;

9) the application of methods of interpretation of legal norms is reflected in the content of the act of interpretation of legal norms, which has an individually determined character ${ }^{13}$.

There is no single approach to the classification of ways of interpretation in the literature.

12 Nersesyants V.S. (2006). Filosofiya prava [Philosophy of Law] ucheb. dlya vuzov. (2nd ed., rev.) (p. 91) Moscow: Norma [in Russian].

${ }^{13}$ Sposib tlumachennja pravovykh norm jak jurydychna kateghorija [Method of interpreting legal norms as a legal category] (issue 21, part 2, Vol. 1) Serija Pravo. [in Ukrainian]. 
The most common is the classification of ways of interpretation into linguistic, logical, systemic (systematic), historical ${ }^{14}$.

E. Vaskovskii proposed the concept of division of the interpretation into literal and real interpretation, which reflects the coverage of the appropriate type of interpretation of the application of techniques aimed at establishing the literal meaning of the text of the law, or its "true, internal meaning" 15 . At the same time, the author determined that the method of grammatical interpretation is used for the literal interpretation, and the logical methods of interpretation are characteristic for the real one.

A. Cherdantsev noted that interpretation is a process of logical deduction and proving the truth of our knowledge about the content of the rules of law, in the process of which all the laws and techniques in the arsenal of logic are applied. From this point of view, he pointed out, that all ways of interpretation are logical ${ }^{16}$. Thus, according to the "form" of the existence of a rule of law the following ways of interpretation are called: linguistic, systematic, historical and functional ${ }^{17}$.

Further, the author notes that in the process of interpretation the interpreter operates with the help of logical techniques the material of the most interpreted norm, without going beyond its boundaries, without resorting to other norms of law (the conclusion from the opposite, the emergence of concepts, analogy, etc.), so it is advisable totality of such to call techniques a logical way of interpretation ${ }^{18}$.

S. Alekseev as a logical way understands the meaning of the rule of law through the use of laws and rules of formal logic; analysis not of words and expressions, but of the concepts they reflect ${ }^{19}$. According to him, this method allows to reveal the content of legal norms, which sometimes does not coincide with the literal meaning due to the unsuccessful choice by the legislator of verbal forms.

${ }^{14}$ Shemshuchenko Yu.S. (Eds.) (2003). Jurydychna encyklopedija [Legal Encyclopedia] (Vols. 1-6) (Vol. 4). Kyiv: Ukrainska Encyklopediya [in Ukrainian].

15 Vas'kovskiy E.V. (1913). Rukovodstvo k tolkovaniyu i primeneniyu zakonov: dlya nachinayushchikh yuristov [Guide to the Interpretation and Application of Laws: For Beginners] (p. 32) Moscow : Br. Bashmakovykh [in Russian].

${ }^{16}$ Cherdantsev A.F. (1972). Voprosy tolkovaniya sovetskogo prava [Interpretation issues of Soviet law] (p. 79) Sverdlovsk [in Russian].

${ }^{17}$ Cherdantsev A.F. (1972). Voprosy tolkovaniya sovetskogo prava [Interpretation issues of Soviet law] (p. 81) Sverdlovsk [in Russian].

${ }^{18}$ Cherdantsev A.F. (1972). Voprosy tolkovaniya sovetskogo prava [Interpretation issues of Soviet law] (p. 81) Sverdlovsk [in Russian].

${ }^{19}$ Alekseeva S.S. (Ed.) (1987) Problemy teorii gosudarstva i prava [Problems of the theory of state and law] Moscow: Yuridichtskaya Literatura [in Russian]. 
We believe that more or less every author is right, because, as noted above, the method primarily reflects the approach of the interpreter, which is different in originality and originality.

From the analysis of the law enforcement practice of the tax authorities, it is possible to use the following methods of interpretation of tax legislation: linguistic, logical, systemic and historical, the essence of which will be analyzed in more detail below.

\section{Linguistic and logical ways of interpreting the rules of law}

The interpretation and understanding of the rules of law depends on the quality of the paper on the will of the legislator, that is, it is mediated by written text. The object of the interpretation is the text of the legal act, as is any language text. It should be noted that language plays a decisive role in the formation of society, one of the functions of the language is the stategovernment. Without language there can be no right ${ }^{20}$. The language of the law is an extremely important factor in the implementation of state will. The verbal-textual envelope of this will must not only add to the law the property of meaningful accessibility, but also harmonize the very content of the law, promote its transformation into a holistic and modern product of intellectual labor $^{21}$. In law-making it is necessary to pay particular attention to the language of the law, carefully construct each sentence, pick words and phrases, make clear and simple statement of the rule of law. This is a list of the first, simplest requirements for those involved in the creation of any law, not just the tax law.

One way to interpret the rules of law, which is especially relevant to tax law, is through linguistic interpretation. Linguistic (philological, linguistic, textual, grammatical) interpretation is the clarification of the content of a rule of law through a grammatical analysis of its verbal formulation using the laws of philology; which is based on the laws of grammar, vocabulary and assumes the analysis of words, sentences, verbal formulations of legal norms. This method is to determine the meaning of each word and expression used in the legal act, the analysis of the grammatical forms of nouns and adjectives, the ways of verbs, the type of participles and the understanding of the grammatical structure of sentences. An important disadvantage of this method is that the grammatical interpretation reveals the literal content of the rule of law, on the basis of which it is not always possible to make a reliable

\footnotetext{
${ }^{20}$ Masenko L.T. (2004). Mova i suspiljstvo: Postkolonialjnyj vymir [Language and Society: Postcolonial Dimension] Kyiv : KM Aekademija [in Ukrainian].

${ }^{21}$ Bjeljakov K.I. (2006). Informacija v pravi : teorija i praktyka [Information in law: theory and practice] (p. 77) Kyiv: KVIC [in Ukrainian].
} 
conclusion. According to A. Ushakov, philologists are only interested in the language form, only its expression, which is detached from its content, so the study of the language of regulatory acts is mostly formal ${ }^{22}$. However, in order to fully and accurately apply the rules of linguistic interpretation of texts of normative legal acts, it is advisable to observe the principle of unity of terminology, unambiguous understanding of legal terms in a particular legal system.

One cannot disagree with the clarified definition of the concept of legallinguistic interpretation given by L. Chulinda. In her view, a legal-linguistic interpretation is a set of mental operations that enable, through linguistic analysis of the content of a written document containing norms of law with the formulated intention of the ruler, to overcome possible contradictions in the understanding of norms or between norms, to clarify the meaning of individual words and text in general ${ }^{23}$.

Criticizing the positivists (especially the representatives of analytical jurisprudence), V. Nersesiants indicated that in the case of the increased interest of the latter to the linguistic and textological interpretations of the law, while explicitly ignoring its legal meaning, legal epistemology is replaced by linguistic ${ }^{24}$.

Fully endorsing the expressed objection to the linguistic approach of all legal epistemology, which would ultimately mean abandoning other ways of interpreting the law, it is also necessary to speak in defense of the linguistic way of interpreting tax legislation.

We believe, that there is an objective need for linguistic interpretation of the acts of legislation, especially tax laws. "The linguistic formulation of normative legal acts, according to the logic of things, taking into account the importance of the normative text for relations between people, ultimately for their life, should be as simple as possible" 25 . However, tax legislation is hardly easy to understand from a linguistic point of view. Many of its

${ }^{22}$ Ushakov A.A. (1983). O yazyke zakonov i zakonodatel'noy stilistike [On the language of laws and legislative style]. Struktura lingvostilistiki i ee osnovnye kategorii - The structure of linguistic stylistics and its main categories. (pp. 82-87) Perm' [in Russian].

23 Chulinda L.I. (2006). Jurydyko-linghvistychne tlumachennja tekstiv normatyvnopravovykh aktiv [Legal and linguistic interpretation of texts of normative legal acts] Kyiv: Atika [in Ukrainian].

${ }^{24}$ Nersesyants V.S. (2006). Filosofiya prava [Philosophy of Law] ucheb. dlya vuzov. (2nd ed., rev.) (p. 91) Moscow: Norma [in Russian].

${ }^{25}$ Rotanj V. (Ed.) (2008) Naukovo-praktychnyj komentar do cyviljnogho zakonodavstva Ukrajiny [Scientific and practical commentary on the civil legislation of Ukraine] (Vols. 1-4) Metodologhija tlumachennja normatyvno-pravovykh aktiv Ukrajiny [Methodology of interpretation of normative legal acts of Ukraine] (Vol. 3) (p. 480) Kyiv: Juryd.kn.; Sevastopolj: In-t juryd.doslidzhenj [in Ukrainian]. 
provisions require grammatical and syntactic analysis in order to clarify the will of the legislator.

Here is an example of the content of the paragraph of the third subparagraph 5.3.3 of clause 5.3 of Art. 5 of the Law of Ukraine "On Corporate Income Taxation", which was in force until the adoption of the Tax Code of Ukraine. It stated that "If the payer of income tax registered as a payer of value added tax simultaneously carries out transactions for the sale of goods (works, services), which are subject to value added tax and are exempt from taxation with such a tax, the value added tax paid as part of the cost of acquiring goods (works, services) related to gross expenses and fixed assets and intangible assets subject to depreciation is included in accordance with the gross cost or book value of the group assets increased by an amount not included in the tax credit the taxpayer pursuant to the Law of Ukraine "On Value Added Tax". The logical structure of the complex sentence being analyzed requires revision and suggests the addition of the conjunction "so that" before the selected words "value added tax".

In the new version of the Tax Code of Ukraine, legislators try to avoid such problems that existed in previous tax laws.

Let us turn to the case law which uses a method of linguistic interpretation.

In one of the cases reviewed by the Supreme Court of Ukraine on December 2, 2015, there was a need to interpret Art. 71, 72, 74 of the Tax Code of Ukraine. The court concluded that in such circumstances, the actions of the supervisory authority regarding the entry into the electronic database of information obtained as a result of the tax audit, including the result obtained by the act, were only the official activity of employees of the tax authority in fulfillment of their professional duties to collect evidential information regarding the presence or absence of documentary confirmation of the respective operations, unless the actions for the exercise of such control are found unlawful in the institution order. These actions alone do not create for the taxpayer any legal consequences in the form of change or termination of his rights and do not give rise to binding legal consequences for him.

It is a matter of fixed substantive law. For example, on the one hand, granting the customs declaration the status of tax, on the other - the establishment as a mandatory requisite of the tax bill of goods in accordance with UCT ZED (Ukrainian Classification of Goods for Foreign Economic Activity) (Art. 201 of the Tax Code of Ukraine).

Thus, the need for linguistic interpretation of tax law acts results from the objective textual complexity of the latter, the need to clarify the etymology of a particular term, and in some cases to correct any syntactic and stylistic errors. However, linguistic interpretation should not be confused with the concept of "literal interpretation", which does not go beyond the "letter of the 
law" and imposes a prohibition in the methodological plan on any logical refinement of the provisions of the law, which traditionally contrasts with interpretation using the methods of logical transformation of norms and associative interpretations.

The provisions of legislative acts are the result of understanding by the law-making bodies of reality, set out in the form of normative text through the main means of social communication - language, that is through words, sentences, groups of sentences. Human language obeys the logic that is inherent in human consciousness. The logic is guided by both those who seek to convey their thoughts and those who seek to perceive them. This also applies to law-enforcement bodies which, within the limits of their powers, inform their respective entities through legal acts and addressees of those requirements. The addressees understand the provisions set out in the regulations, because they have the same reasoning logic as the law-making body. With this in mind, any interpretation of regulations is a logical interpretation, but it does not prevent the identification of certain ways of interpretation and designation by special terms without the use of the word "logical". However, even after isolating the relevant types of interpretation, logical interpretation still has some meaning. This justifies the use of the term "logical interpretation of legal acts (regulations, acts of law)".

By means of logical interpretation, the provisions of legal acts reveal the legal content, which is not textually expressed in them.

A large part of the provisions required logical interpretation, which were in force before the adoption of the Tax Code of Ukraine, which in the example of par. 17.3. Art. 17 of the Law of Ukraine "On the procedure for paying off taxpayers obligations to budgets and state trust funds", according to which the payment (collection) of penalties provided for in this Article shall be equal to the payment (collection) of the tax and the appeal of their amounts. Carrying out a logical analysis of the stated norm, we will conclude that the word "appeal" is omitted in the first part of this rule, since in the current wording it turns out that the payment (penalty) of penalties equates to the payment (charge) of tax and the appeal of their amounts. However, it is obvious that the payment (penalty) of penalties cannot simultaneously be equal to the payment (charge) of the tax and to the appeal of their sums, since these are different concepts.

Thus, in previous laws, the appeal of the tax liability determined by the tax authority is regulated by par. 5.2.2. of this Law, and payment and recovery par. 15.1.1., which sets the statute of limitations.

On the basis of the above, it is necessary to state the reasons for presenting the analyzed provision in the following wording: "payment (penalty) of 
penalties and appeal of their sums stipulated by this Article shall be equal to payment (charge) of tax and appeal of their amounts".

Today, in the current version of the Tax Code, the same rules have remained, but in a different interpretation: appeals against decisions of regulatory bodies are regulated by Art. 56 of the PC (Tax Code) of Ukraine, and payment of the monetary obligation is determined in par. 14.1.39 of the PC (Tax Code) of Ukraine; limitation period provided by Art.102 PC (Tax Code) of Ukraine.

The example that will be set forth here, is particularly illustrated by the fact that, without taking into account legal prescriptions that are indirectly derived from acts of law and which are found when interpreted by a conclusion on the basis of incomplete logical identity (a fortiori), enforcement loses its legal character and acquires and even vulgar positivism.

This is a different interpretation of subpar. (a) of par. 7.7.2 of part 7.7 of Art. 7 before the current Law "On Value Added Tax": "Budget compensation is subject to ... part of the negative value (liability for value added tax Auto.), which is equal to the amount of tax actually paid by the recipient of goods (services) in the previous tax period to suppliers of such goods (services). "In one case, the court found that the amount of the budgetary compensation could not take into account the amount of value added tax paid in the tax period that preceded the aforementioned prior tax period. This was strictly in line with the law, which the court had read harshly with the signs of positivism referred to above. The plaintiff was outraged by the judgment and characterized the legislative provision on the basis of which he was denied the claim and which was cited above as inanimate and technocratic.

Another court interpreted the same legislative provision as follows: "Within the meaning of subpar. (a) of par. 7.7.2 of Art. 7 of the Law on "Value Added Tax", when determining the amount of budgetary compensation, account should be taken of the value added tax paid by the plaintiff in the composition of the price of goods not only in the previous tax period, but also in all tax periods that preceded the previous tax period; provided that these amounts have not previously been included in the tax credit or taken into account in determining the amount of budgetary compensation".

If we read carefully this fragment of the court order and compare it with the previous one, one can see how the letter of the law comes to life in the given court fragment, thanks to the intuition of experienced judges, as it deprives itself of the signs of technocratism and acquires the signs of rationalism, sociality, civilization.

But it also draws attention to the fact that the content of the last ruling of the court was adopted without reliance on science, on the basis of intuition 
with reference to the meaning of the law. This court order would have become scientific if the court had so motivated its decision: "Subparagraph" a "of par. 7.7.2 of part 7.7 of Art. 7 of the Law "On Value Added Tax" prescribes when determining the amount of budgetary compensation to take into account the value added tax paid by the payer of such tax in the price of goods in the previous tax period. From this provision indirectly follows and a fortiori conclusion reveals a legal prescription according to which value added tax paid by the payer of value added tax in the periods preceding the tax period, which in subpar. 7.7.2 part 7.7 of Art. 7 of the Law "On value added tax" is marked as preliminary, the more it should be taken into account in determining the amount of budgetary compensation claimed by the taxpayer for the reporting tax period, provided that the payer of value added tax or not previously exercised the right to a tax credit or did not take into account the value added tax paid in the periods preceding the previous tax period when determining the amount of budgetary compensation.

It is interesting how the legislator responded to the lack of certainty that the provisions of subpar. "a" of par. 7.7.2 of part 7.7 of Art. 7 before the current Law on Value Added Tax due to lack of methodology for interpreting acts of legislation. By the Law "On the State Budget of Ukraine for 2008 and Amendments to Certain Legislative Acts of Ukraine" in this paragraph the words "in the previous tax period" were replaced by the words "in the previous tax periods". The same wording is used in par "a" of part 200.4 of Art. 200 PC. (Tax Code).

Thus, the results of the logical interpretation of tax laws can formulate a more successful and logically correct formulation of the interpreted provision.

The content of the logical way of interpretation is specified in its techniques, which are the logical transformation of the provisions of the law. The conformity of such a transformation to the requirements of logical (correct) thinking, that is, to the laws of logic, is a criterion for delimiting the interpretation made in this way from interpretation contrary to law.

\section{Systematic, historical and teleological ways of interpreting the rules of law}

It should be noted that the rules of law are interconnected with each other, that is, in a particular system. This is the reason for determining the content of individual rules by comparing them and tracing relationships with other rules of law. According to N. Onishchenko, the systematic way of interpretation is to identify the interconnection and interaction of legislative acts, the harmonization of each new legislative act with the constitutional norms, acts 
of their own and other branches of law, as well as those that provide legal liability for violations of existing legislation ${ }^{26}$.

The interpretation of a rule of tax law must be based on the consideration of a particular rule as part of the general system of law. Failure to do so may result in a gross violation of the law, rights and interests of taxable persons. Courts resort to a systematic interpretation of the law to find out the logical relationship between legal categories, that is, for example, the generic belonging of one concept to another.

For example, in one case the Supreme Court of Ukraine stated: "as follows from the systematic analysis of par. 1.1. and 1.2 Art. 1 of the Law of Ukraine On the Procedure for Repayment of Taxpayers' Obligations to the Budgets and State Trust Funds of 21.12.2000 No. 2181-III, which at that time settled controversial relationships, under the taxpayer's tax liability in the context of subpar. 15.1.3. par. 15.1 of Art. 15 should be understood as the amount of tax (principal payment), as well as penalties and penalties."

In a ruling of the Supreme Court of Ukraine of November 17, 2015, a panel of judges found that judges of previous instances had violated par/ 74.1 of Art. 74 of the PC (Tax Code) of Ukraine, stating that tax information collected under this Code could be stored and processed in the control databases bodies or directly by the officials (officials) of the controlling bodies.

On the basis of the act, the Inspectorate adjusted the Company's tax reporting indicators in all information bases of the State Tax Service bodies and made changes to the respective system, thereby reducing the amount of tax credit and tax liabilities by counterparties for April 2014.

The conclusions set out in the act are a reflection of the actions of tax inspectors, do not give rise to legal consequences for the taxpayer, and, accordingly, such an act does not violate the latter's rights.

The inclusion of the power of the subject in the database of information about such verification does not create any obstacles for the activity of the taxpayer.

Based on the systematic interpretation of Art. 71, 72, 74 of the PC (Tax Code), the panel of judges concluded that the information received from the tax control was used for the information and analytical support of the activity of the controlling body and could not be excluded from the databases if such control was carried out. not found unlawful in due course. Therefore, such submissions on the basis of the act are unjustified.

${ }^{26}$ Onishhenko N.M. (2002). Pravova systema i derzhava v Ukrajini [Legal system and state in Ukraine] Kyiv: Instytut derzhavy i prava im. V.M. Korecjkogho NAN Ukrajiny [in Ukrainian]. 
A similar legal position on the application of these substantive law rules has already been expressed by a panel of judges of the Judicial Chamber in administrative cases of the Supreme Court of Ukraine in its rulings of December 9, 2014 (Case No. 21-511a14).

An example of a systematic interpretation may also be the decision of October 29, 2014 in Case K / 9991/25760/12, in which the Supreme Administrative Court of Ukraine, by establishing the procedure for repayment of taxpayer's obligations, performs a comprehensive analysis of tax legislation. In doing so, the court provides clarification on the sequence of stages of tax debt recovery. Yes, the tax authority has the right to use the property of the payer to repay his tax debt in case of insufficient or lack of funds in the accounts of the enterprise or lack of information about the existence of such accounts at all. According to the content of Art. 95 of the Tax Code of Ukraine, it does not follow that the tax authority has the right to go to court for permission to pay off tax debt at the expense of the payer's property, bypassing the stage of collection of funds from the taxpayer to pay off his tax debt.

In its ruling of April 12, 2016, in the case No. 21-240a16, the Supreme Court of Ukraine, analyzing the legal norms for imposing a levy on the taxpayer, using a systematic way of interpretation, produces the grounds on which the taxpayer may be held liable on the basis of par. 123.2 of Art. 123 PC (Tax Code) in the form of tax collection of taxes, fees (compulsory payments), which are subject to accrual without applying a tax benefit. Yes, the court notes that such liability can only be applied in the presence of statutory purposes and / or conditions or purposes of using sums of funds not paid to the budget, and provided that proving the use of such sums is not for the purpose and / or contrary to the conditions or purposes defined by law. Article 18 of the Law of Ukraine of March 19, 1996 No. 93/96-BP "On the regime of foreign investment", according to which the Company was exempted from the payment of duties on import of a bus, as well as the said Law as a whole, did not specify the purpose and / or conditions or purposes of using the amounts of funds that were not paid to the budget as a result of the application of the privilege established by it, therefore the application to the Society of the established par. 123.2 of Art. 123 PC (Tax Code) liability is unfounded.

Therefore, as the law of practice shows, systematic and logical ways of interpreting tax law norms are perhaps the most common, which is understandable given the complex nature of tax law. However, in order to find out the true will of the legislature of the court, a systematic way of interpretation is not enough.

The need for a historical interpretation of the rule of law arises quite often. This method is to compare the applicable rule of law with those previously applied. An interpreter examines normative material in a historical, 
retrospective or perspective perspective that facilitates an understanding of the purpose of adopting or amending this legal rule. Historical interpretation makes it possible to understand more fully and fully the meaning that the legislator sought to bring into force. However, not all scholars identify the historical way of interpreting the rules of law as independent. According to A. Bonner, historical interpretation is a kind of systemic. It takes into account the historical aspect of the legal system ${ }^{27}$.

Very successful is the statement about the historical way of interpreting the rules of law of the French theorist J.-L. Bergell, the historical method is based on the idea that law is a process, a dynamic act of society, and laws act only as a temporal reflection, which must evolve with the changing social environment. Thus, laws can be removed from the original will of the legislator and make new sense in order to adapt to current requirements that are put forward by reality ${ }^{28}$.

Thus, in the blighty system of legislation, the historical method of interpretation is subject to all rules of law adopted before 1991, that is during the Soviet Union. The inertia of the domestic lawmaker in the replacement of obsolete norms of law leads to the fact that many important spheres of public life have for a long time been regulated (and in some cases continue to be regulated today) by rules adopted in the context of Soviet realities. Indicative examples are the Labor Code of Ukraine (1972), the Residential Code of Ukraine (1983), and the Code of Administrative Offenses (1984), which remain in force. Although a considerable number of fragmentary changes have been introduced to these codes since 1991, this does not solve the problem of their interpretation, since the concept of legal regulation of public relations is outdated ${ }^{29}$.

Let us turn to the enforcement example. At present, the Tax Code of Ukraine does not provide legal regulation of state liability for late payment of the amount of budget compensation. Therefore, the question arises whether this is a gap in legal regulation, or the absence of a relevant provision in the law is the will of the legislator.

As the task of interpretation is "to find out the opinion and will of the legislator" ${ }^{\prime 30}$, then in the absence of the will of the legislator to directly regulate the

27 Bonner A.T. (1980) Primenenie normativnikh aktov v grazhdanskom protsesse [Application of normative acts in civil procedure] (p. 19) Moscow: Yuridichtskaya Literatura [in Russian].

${ }^{28}$ Berzhel' Zh.-L. (2000). Obshchaya teoriya prava [General Theory of Law]. Danilenko V.I. (Ed). (Churshukova G.V. Trans.) (p. 432) Moscow: NOTA BENE [in Russian].

${ }_{29}$ Kryvycjkyj Yu.V. (2012). Istorychnyj sposib tlumachennja norm prava: zaghaljnoteoretychnyj aspekt [The historical way of interpreting the rules of law: a general theoretical aspect] (pp. 32-36) Kyiv: Chasopys Kyjivsjkogho universytetu prav [in Ukrainian].

30 Vas'kovskiy E.V. (1913). Rukovodstvo k tolkovaniyu i primeneniyu zakonov: dlya nachinayushchikh yuristov [Guide to the Interpretation and Application of Laws: For Beginners] (p. 34) Moscow : Br. Bashmakovykh [in Russian]. 
liability of the state for delayed fulfillment of the obligation to pay budgetary compensation, it is impossible to speak about the existence of a gap.

However, the absence of a reference in the Tax Code of Ukraine on the responsibility of the state for late payment of budget compensation does not indicate the existence of a gap.

The role of historical interpretation of tax law may also be to establish the existence or absence of a gap in the legal regulation of tax relations. If, as a result of the historical interpretation of the tax law act, it turns out that the legislator had previously settled a certain tax issue, and in the current legislation there was no such or any other regulation, then it is impossible to conclude unequivocally the existence of a gap in law, because the law itself, as stated above, the phenomenon is dynamic. Since the adoption of the previous legal norms, other regulations could be adopted to regulate this issue. Therefore, other ways of interpreting, in particular, systemic ones, should be used to conclude that there is or should not be a specified gap.

The following will also be illustrative of the possibility of an effective use of the historical way of interpreting tax law. As Art. 26 of the Law of Ukraine "On Freedom of Conscience and Religious Organizations" of April 23, 1991 No. 987-XII specifies that the legislation of labor, generally applicable, applies to citizens who work in religious organizations and enterprises, charitable institutions established by them under the terms of an employment contract. state social insurance, taxation. At present, the provisions of the Tax Code do not include the concept of "tax legislation", such term was included in the legislative acts that were in force prior to the adoption of the Tax Code. Currently, the term "taxation legislation" is replaced by "tax law." Therefore, based on the "letter of the law", its provisions would be inapplicable at this time, but the subject of interpretation, knowing that in historical retrospect, the term "taxation legislation" has been transformed into "tax law", applies the current provisions of tax law.

It should be noted that, in addition to the above methods of interpretation, scientists also identify a teleological way of interpretation. The teleological method of interpretation is closely related to the methods of interpretation described above. P. Rabinovich points to the relationship of teleological and historical mode of interpretation. So, the historical way of interpretation is to establish what came before the publication and at the time of the law, and the teleological way of interpretation reveals what will (should) be after the implementation of the law in life ${ }^{31}$.

${ }^{31}$ Rabinovich P.M. (1966). Sotsialisticheskaya zakonnost' i tselesoobraznost' v sovetskom prave [Socialist legality and expediency in Soviet law] Extended abstract of candidate's thesis. Moscov [in Russian]. 
T. Nasirov, justifying the independence of the teleological way of interpretation, rightly points out that all ways of interpretation contribute to clarifying the purpose of the rule of law, but at the same time none of them is interpreted in accordance with its purpose. In this regard, the author sees the specifics of the teleological method of interpretation in that it investigates an objective result, aimed at the implementation of a norm that goes beyond the internal logical content of the rule of law and does not coincide with the analysis of the relationship of the norm with other prescriptions. In this respect, the teleological method of interpretation is not covered by other means, since it is the only one that is directly aimed at clarifying the meaning of a rule of law, depending on the results that should be achieved in its implementation ${ }^{32}$.

Considering that the goal is the basic structural element of the rule of law, and the form and content act as means to achieve it, it is not surprising that the structure of techniques of the teleological method of interpretation is a place for the elements of logical, linguistic and systematic ways of interpretation. The rule of law has a strong willed character, that is, a power commandment, which establishes a certain obligatory variant of the behavior of the subjects in one or other circumstances.

B. Malyshev exploring the teleological method of interpretation points to specific techniques of this method of interpretation, namely: the possibility of determining the purpose of the rule of law by correlating it with the relevant norms-goals. As the author rightly points out, at first glance, this technique duplicates the reception of a systematic interpretation of the relationship of the interpreted rule with the principle of law, but in the teleological way, the relationship between the principle and the norm is considered in the context of the meta-means model, and not in the context of a systemic interpretation model ("whole - part", "abstract - concrete") ${ }^{33}$.

The opinion of Judge of the Permanent Chamber of International Justice in the League of Nations M. Antsilotti remains relevant, according to which it is impossible to conclude on the true purpose of an article of any convention until its goals and objectives have been determined. Therefore, these questions must be answered before interpreting ${ }^{34}$.

32 Nasyrova T.Ya. (1988). Teleologicheskoe (tselevoe) tolkovanie sovetskogo zakona. Teoriya i praktika [Teleological (target) interpretation of Soviet law. Theory and practice] (pp. 69-71) Kazan' : Izd-vo Kazanskogo universiteta [in Russian].

33 Malyshev V.P. (2011). Teleologhichnyj sposib tlumachennja norm prava: zaghaljnoteoretychni aspekty [The teleological way of interpreting the rules of law: general theoretical aspects] Kyiv: Advokat (10 (133) ed.) (p. 7-14) [in Ukrainian]

${ }^{34}$ European Court of Human rights, Engel and Others v. the Netherlands judgment of 8 June 1976. European Court of Human Rights Portal. Retrieved from www.echr.coe.int. 


\section{CONCLUSION}

The Constitution of Ukraine incorporates the best global experience of constitutional regulation of public relations. It directs ongoing law-making activities. Therefore, Ukraine has a system of legislation that meets the needs of intensive progressive development of political, economic, social spheres, the needs of affirmation of human honor and dignity, its moral, intellectual and physical development. The task is only to ensure the implementation of the Constitution, laws and other legislative acts. The leading role in this belongs to the law enforcement agencies.

But the law enforcement agencies can fulfill their part of the task of introducing into the public relations of the Constitution, laws of Ukraine and other acts of legislation only on condition that they will have perfect tools for rational elaboration of the provisions of the Constitution, laws, and other legal acts. One of the rational tools for elaborating normative legal acts is the methods of interpretation, which are determined by the set of techniques and means used by the law enforcement agency in determining the content of the legal norm.

The main ways of interpreting normative legal acts are: philological (linguistic), logical, systemic, historical and teleological.

The correct application of the provisions of acts of taxation legislation can be ensured by the methodology of their interpretation, if it is possessed by tax authorities, judges and other specialists working with the relevant acts.

\section{SUMMARY}

The article is devoted to the actual problem of ways of interpreting acts of the legislation of Ukraine on taxation. The need for a transition from an intuitive to a rational approach to drafting tax legislation was emphasized. The scientific approaches to the definition of "ways of interpretation" are covered. The role of ways of interpreting tax legislation acts in determining whether or not there is a gap in the legal regulation of tax relations is analyzed. Approaches to the classification of ways of interpretation are investigated and the methods and problems of interpretation of acts of taxation legislation are characterized. The importance and necessity of applying such methods of interpretation as linguistic, logical, systemic, historical and teleological are analyzed in practice. An analysis of the norms of the current tax legislation as well as the legislation that has been in force is given, taking into account the methods of interpretation specified by the author. The purpose and results of the interpretative activity of tax legislation acts are determined. 


\section{REFERENCES}

1. Alekseev S.S. (1999). Sotsial'naya tsennost' prava $v$ sovetskom obshchestve [The social value of law in Soviet society]. Moscow: Yuridichtskaya Literatura [in Russian].

2. Berzhel' Zh.-L. (2000). Obshchaya teoriya prava [General Theory of Law]. Danilenko V.I. (Ed). (Churshukova G.V. Trans.) Moscow: NOTA BENE [in Russian].

3. Bjeljakov K.I. (2006). Informacija $v$ pravi : teorija $i$ praktyka [Information in law: theory and practice] Kyiv: KVIC [in Ukrainian].

4. Bonner A.T. (1980) Primenenie normativnikh aktov v grazhdanskom protsesse [Application of normative acts in civil procedure] Moscow: Yuridichtskaya Literatura [in Russian].

5. Vas'kovskiy E.V. (1913). Rukovodstvo $k$ tolkovaniyu i primeneniyu zakonov: dlya nachinayushchikh yuristov [Guide to the Interpretation and Application of Laws: For Beginners] Moscow : Br. Bashmakovykh [in Russian].

6. Voplenko N.N. (1993). Tolkovanie prava. Obshchaya teoriya prava [The interpretation of law. General Theory of Law] kurs lektsiy. Nizhniy Novgorod [in Russian].

7. Keljman M.S., Murashyn O.Gh. (2006). Zaghaljna teorija derzhavy $i$ prava [General theory of state and law] Kyiv: Kondor [in Ukrainian].

8. Kryvycjkyj Yu.V. (2012). Istorychnyj sposib tlumachennja norm prava: zaghaljnoteoretychnyj aspekt [The historical way of interpreting the rules of law: a general theoretical aspect] Kyiv: Chasopys Kyjivsjkogho universytetu prav [in Ukrainian].

9. Malyshev V.P. (2011). Teleologhichnyj sposib tlumachennja norm prava: zaghaljnoteoretychni aspekty [The teleological way of interpreting the rules of law: general theoretical aspects] Kyiv: Advokat (10 (133) ed.) [in Ukrainian].

10. Masenko L.T. (2004). Mova i suspiljstvo: Postkolonialjnyj vymir [Language and Society: Postcolonial Dimension] Kyiv : KM Aekademija [in Ukrainian].

11. Nasyrova T.Ya. (1988). Teleologicheskoe (tselevoe) tolkovanie sovetskogo zakona. Teoriya i praktika [Teleological (target) interpretation of Soviet law. Theory and practice] Kazan' : Izd-vo Kazanskogo universiteta [in Russian].

12. Rotanj V. (Ed.) (2008) Naukovo-praktychnyj komentar do cyviljnogho zakonodavstva Ukrajiny [Scientific and practical commentary on the civil legislation of Ukraine] (Vols. 1-4) Metodologhija tlumachennja normatyvnopravovykh aktiv Ukrajiny [Methodology of interpretation of normative legal acts of Ukraine] (Vol. 3) Kyiv: Juryd.kn.; Sevastopolj: In-t juryd.doslidzhenj [in Ukrainian]. 
13. Nersesyants V.S. (2006). Filosofiya prava [Philosophy of Law] ucheb. dlya vuzov. (2nd ed., rev.) - Moscow: Norma [in Russian].

14. Onishhenko N.M. (2002). Pravova systema $i$ derzhava v Ukrajini [Legal system and state in Ukraine] Kyiv: Instytut derzhavy i prava im. V.M. Korecjkogho NAN Ukrajiny [in Ukrainian].

15. Alekseeva S.S. (Ed.) (1987) Problemy teorii gosudarstva i prava [Problems of the theory of state and law] Moscow: Yuridichtskaya Literatura [in Russian].

16. Rabinovich P.M. (1966). Sotsialisticheskaya zakonnost' $i$ tselesoobraznost' $v$ sovetskom prave [Socialist legality and expediency in Soviet law] Extended abstract of candidate's thesis. Moscov [in Russian].

17. Sposib tlumachennja pravovykh norm jak jurydychna kateghorija [Method of interpreting legal norms as a legal category](issue 21, part 2, Vol. 1) Serija Pravo. [in Ukrainian].

18. Todyka Yu.M. (2001). Tlumachennja konstytuciji i zakoniv Ukrajiny: teorija i praktyka: monoghraf [Interpretation of the constitution and laws of Ukraine: theory and practice: monograph] Kharkiv: Fakt [in Ukrainian].

19. Ushakov A.A. (1983). O yazyke zakonov i zakonodatel'noy stilistike [On the language of laws and legislative style]. Struktura lingvostilistiki i ee osnovnye kategorii - The structure of linguistic stylistics and its main categories. Perm' [in Russian].

20. Cherdantsev A.F. (1972). Voprosy tolkovaniya sovetskogo prava [Interpretation issues of Soviet law] Sverdlovsk [in Russian].

21. Chulinda L.I. (2006). Jurydyko-linghvistychne tlumachennja tekstiv normatyvno-pravovykh aktiv [Legal and linguistic interpretation of texts of normative legal acts] Kyiv: Atika [in Ukrainian].

22. Shemshuchenko Ju.S. (Eds.) (2003). Jurydychna encyklopedija [Legal Encyclopedia] (Vols. 1-6) (Vol. 4). Kyiv: Ukrainska Encyklopediya [in Ukrainian].

23. European Court of Human rights, Engel and Others v. the Netherlands judgment of 8 June 1976. European Court of Human Rights Portal. Retrieved from www.echr.coe.int.

\section{Information about the author:}

Igor Samsin,

Honored Lawyer of Ukraine, Doctor of Laws, Docent, Professor at the Department of Constitutional,

Administrative and Financial Law, Khmelnytsky University of Management and Law 8, Heroyiv maydanu str., Khmelnitsky, 29000, Ukraine

ORCID ID: orcid.org/0000-0003-4118-8452 


\section{MULTICULTURALISM: A HUMAN RIGHTS-BASED APPROACH}

\section{Vitalii Serohin}

\section{INTRODUCTION}

The modern state is a nation-state, that is, a sovereign political and legal organization of the people. However, the people, being as an organic unity within internal- and external political relations, as the bearer of a single political will, turns out on closer examination to be complex in ethnic, religious, ideological and many other features. At the same time, all modern states in the structural plan are organized around one or several dominant social groups, called state-forming, which, as a rule, constitute the majority of the population of the country and are the bearers of a certain culture, including language, religion, customs, mode of life, etc. From this point of view, even the states with a mono-national population, such as North and South Korea, Japan, or Scandinavian countries, are multicultural in a broad sense. The situation is even more complicated in the context of globalization, with unprecedented rates of population migration and cultural exchange. All this puts before the state and society the problem of finding the optimal interaction between the dominant (predominant) groups of the population, including titular ethnic groups, and national, linguistic and other cultural minorities.

Initially, the concept of a multicultural society had a rather clear ideological orientation: it reflected the growing concern of politicians, government officials and public figures that immigrants and their children could successfully integrate into society, despite existing differences in education, income, degree of involvement into state administration, political and religious views, etc. Multiculturalism was intended to protect the divided society from serious social conflicts, including from civil wars on ethnic and religious grounds, to promote the solidarity of a multinational and polyconfessional society, to guarantee its progressive development in terms of mutual enrichment of cultures. However, the problems of intercultural interaction have in no way lost their urgency over the past decades, when the policy of multiculturalism was proclaimed at national and international levels; moreover, they have become even larger and more diverse.

Unfortunately, the problems of multiculturalism are currently being discussed predominantly within the political aspect, while their practical resolution requires, as a rule, the transition into the legal sphere, into the plane of interpersonal, intergroup and inter-institutional relations. The fact is that a 
significant part of the individual's needs related to cultural identity are realized in the legal sphere; the behavior of people, where their cultural identity is manifested, is largely regulated by the norms of law and is embodied through certain forms of enforcement (use of rights, fulfillment of duties, observance of prohibitions). Accordingly, all participants in intercultural dialogue, in the legal sense, act as bearers of certain legal rights, freedoms and obligations, both individual and collective.

On this basis, the author of this article attempts to determine the ways of solving the problems of intercultural interaction precisely within the legal sphere. As the methodological basis, the author has offered to use the socalled "a human rights-based approach", which is to consider certain issues through the prism of guaranteeing human rights as the main criterion for social progress, the main indicator in assessing the level of development of the state and society. Such an approach is characterized by high humanism and, at the same time, is sufficiently effective to resolve specific cases arising in the law enforcement practice of various multicultural states.

\section{The Problem of Intercultural Interaction in Modern Society: the Main Causes of the Origin and Approaches to Solving}

Consideration of the problem of multiculturalism requires clarity in definitions, however it is difficult to accomplish this with regard to culture. In view of the extreme abundance of doctrinal approaches to the definition of the phenomenon of culture, let us refer to positive law. In accordance with the Mexico City Declaration on Cultural Policies (1982), the culture, in the broadest sense, can be viewed as "a combination of pronounced traits, spiritual and material, intellectual and emotional that characterize a society or social group. The culture encompasses, apart from art and literature, a way of life, fundamental human rights, value systems, traditions and faith" ${ }^{1}$. It seems appropriate to consider multiculturalism in the same context.

The presence of several, sometimes significantly different, cultures within one state system inevitably creates the need for a fundamental solution of the issue about their relationship and interaction. In terms of legal state system, this political decision, by its nature, must be embodied in the legal form, including the constitutional one.

There are three main approaches to solving the problem of intercultural interaction in the most general form: a) "dissolution" of cultural minorities among the total mass of dominant cultural groups (the principle of

\footnotetext{
${ }^{1}$ Mexico City Declaration on Cultural Policies. World Conference on Cultural Policies, Mexico City, 26 July - 6 August 1982. Retrieved from: https://culturalrights.net/descargas/ drets_culturals401.pdf (accessed 12.11.2019).
} 
assimilation); b) mutual "dissolution" of primary cultures together with the formation of a new, synthetic, nation-wide nation (the principle of a "meltingpot"); c) recognition and preservation of all cultural differences among all social groups (the principle of recognition and tolerance).

Starting from the second half of the XX century, the overwhelming majority of Western democracies prefer the latter way, which received the name of multiculturalism. Without going too deeply into the theory and history of the issue, we would like to note that multiculturalism in the generally accepted sense is a policy aimed at developing and preserving cultural differences in a single country and in the world in the whole, and the theory or ideology justifying such a policy; it is one of the aspects of tolerance, which consists in demanding the parallel existence of cultures for the purpose of their mutual penetration, enrichment and development within the universal direction of mass culture. Multiculturalism, applied to modern Europe, supposes, first of all, the inclusion of the elements of immigrants' cultures from the "third world" countries into its cultural field. The very concept of "multiculturalism" has been known since the 40's of the XX century, it became relevant in the 60's, and serious comprehensive studies of this phenomenon were deployed in the 90's - in the optimistic decade of multiculturalism, when it really seemed that it could be realized practically in any multicultural society.

It was originally planned that the children of migrant workers will persistently study in the education system of Western Europe and North America (to compensate their lower level of education and linguistic skills), will get decent work, compete with representatives of the titular nation on equal terms, will be inspired with the "national spirit" and finally will integrate into the political nation preserving their cultural identity. However, in practice, it happened quite differently: the descendants of migrant workers instead of integration, created their own mono-cultural groups, sufficiently closed to the outside environment - it was the situation with the Turks in Germany, Moroccans in the Netherlands, Algerians in France, Pakistanis in the UK and so on. Their representatives become active participants in street gangs, often have conflicts with neighbors or classmates and teachers, openly opposing themselves not only to the cultural traditions of the political nation, but also to the existing system of justice. It is not surprising that such facts, spread by the mass media, create and support negative stereotypes in society about cultural minorities and, of course, do not contribute to the promotion of multiculturalism in the public consciousness.

The re-actualization of multiculturalism theme has been recently explicitly linked to the migration crisis, especially in Europe. The supporters of this concept, in the case of immigrants, emphasize that multiculturalism is quite compatible 
with the integration of immigrants into society, and does not contradict it, since it provides more fair conditions for immigrants' integration.

However, the beginning of the XXI century was marked by a serious disappointment with the policy of multiculturalism throughout Europe, clearly manifested in the official statements of the heads of the states and governments in Great Britain, Germany, France and other countries.

The reasons for the disappointment, of course, were significant. Thus, according to the results of a sociological survey conducted in 2009 by the order of the German government among migrants, the Turks, who make up more than half of the 6.8 million immigrants in Germany, are worse integrated in the German society than all others. It turned out, for example, that every fourth Turks in Germany does not know German, and every second almost does not communicate with the Germans. The situation with education is not better: $67 \%$ of the Poles, $60 \%$ of the Greeks and $44 \%$ of the Italians living in Germany, have completed secondary education, and only $41 \%$ of the Turks have the secondary education. At the same time, the number of the Turks living on social benefits is up to $15 \%$ in their group, while among the Greeks this indicator is only $7.5 \%$. According to German Interior Minister Thomas de Maiziere, $10-15 \%$ of migrants in Germany openly refuse to integrate into German society ${ }^{2}$.

The problem of multiculturalism remains relevant for Ukraine, however for a few other reasons. There is no problem of a massive wave of migrants in Ukraine, mainly due to a serious social and economic crisis, but there is a problem of interethnic and inter-confessional relations. So, according to the latest population census (2001), Ukrainians make up the majority of the national population of Ukraine, their number is about 37.54 million people ( $77.8 \%$ of the total population). However, almost $15 \%$ of citizens, who identified themselves as Ukrainians by nationality (that is, every sixth), indicated Russian as their native language. The number of representatives of other nationalities in Ukraine is about 11 million people $(22.2 \%$ of the total population). The most numerous of them are Russians, Jews, Belarusians, Moldovans, Bulgarians, Poles, Hungarians, Romanians, Greeks, Tatars, Armenians and Gypsies. The Russians occupy the first place among the national minorities in Ukraine -8.3 million people, or $17.3 \%$ of the total population. At the same time, almost all citizens, naming themselves Russians by nationality $(96 \%)$, indicated Russian as their native language ${ }^{3}$.

${ }^{2}$ Turki plokho integriruyutsya v Germanii [Turks poorly integrate in Germany]. InterRight. April 17, 2010. Retrieved from: http://inright.ru/news/id_984 (accessed 12.11.2019) (in Russian).

${ }^{3}$ Pro kiljkistj ta sklad naselennja Ukrajiny za pidsumkamy Vseukrajinsjkogho perepysu naselennja 2001 roku [About the number and composition of the population of Ukraine according to the results of the 2001 All-Ukrainian Population Census]. Retrieved from: http://2001.ukrcensus.gov.ua/ results/general/nationality/ (accessed 12.11.2019) (in Ukrainian). 
At the same time, Ukraine has been and remains a multi-confessional state with a wide structure of faiths. Nowadays there are about 37 thousand religious organizations of 55 confessional lines on its territory ${ }^{4}$. Each confession, by definition, has its own characteristics, differences, its doctrinal paradigm and cult system. These features and differences become most visible in the process of the relationship between different confessions as components of a single poly-confessional religious space of society.

It comes as no surprise, when Charles Taylor - the world-famous philosopher, professor at McGill University in Canada, one of the "gurus of multiculturalism", who came to Ukraine in the summer of 2013, suggested that the future of our country is "in the diversity of a multicultural context" . "If Ukraine can recognize the existence and coexistence of such diversity in the country, this will be its great strength, both for building its future and for having its role in the region", he said.

At the same time, discussions about the acceptability and necessity of multiculturalism are still go on. The supporters of multiculturalism see it as a manifestation of humanism, tolerance and pluralistic democracy, a way of ensuring intercultural harmony and guaranteeing the rights of various kinds of minorities. In turn, the critics of this policy say that multiculturalism leads to cultural expansion, the complete destruction of the centuries-long cultural backgrounds, developed cultural traditions, or, at best, to the eclectic averaging and universal assertion of global, national and impersonal mass culture. According to them, if the low level of cultural development of migrants is undoubtedly increased, then the high level of culture of the country taking multiculturalism is invariably falling. Besides, in practice it turns out that multiculturalism, highlighting certain groups and providing resources for strengthening ethnic communities and organizations, destroys the social unity and divides the community itself ${ }^{6}$.

\footnotetext{
${ }^{4}$ Pro stan i tendenciji rozvytku relighijnoji sytuaciji ta derzhavno-konfesijnykh vidnosyn $\mathrm{v}$ Ukrajini za 2012 rik: Informacijnyj zvit Ministerstva kuljtury Ukrajiny [On the Status and Trends of the Development of the Religious Situation and State-Confessional Relations in Ukraine in 2012: Information Report of the Ministry of Culture of Ukraine]. Retrieved from: http://www.irs.in.ua/index.php?option=com_content\&view=article\&id=1212\%3A1\&catid=51\%3 Astats\&Itemid $=79 \&$ lang $=$ uk (accessed 12.11.2019) (in Ukrainian).

5 Charl'z Teylor: «V raznoobrazii mul'tikul'turnogo konteksta - budushchee Ukrainy» [Charles Taylor: "In the diversity of multicultural context - the future of Ukraine"]. Zerkalo nedeli Зеркало недели [Mirror of the week]. 2013. Vol. 24. June 26 - July 5. URL: https://zn.ua/socium/charlz-teylor-v-raznoobrazii-multikulturnogo-konteksta-buduscheeukrainy-_html (accessed 12.11.2019) (in Russian).

${ }^{6}$ Eisenberg A. (2006) Equality, trust and multiculturalism. Social Capital, Diversity, and the Welfare State / F. Kay and R. Johnson (eds). Vancouver: University of British Columbia Press, 2006, pp. 67-68.
} 
Sometimes supporters and opponents of multiculturalism find fundamentally different qualities there. For example, some antimulticulturalists, such as Brian Barry and Samuel Huntington, say that multiculturalist ideas are inherently illiberal - ie., that multiculturalism is based on a repudiation of Enlightenment values of individual freedom, democratic citizenship and universal human rights, and it is precisely this repudiation of core Enlightenment principles which explains why multiculturalists seek to challenge traditional Western models of national citizenship in the name of cultural difference. At the same time multiculturalists, vice versa, accept that multiculturalism is rooted in familiar liberal-democratic ideals of equality, freedom and citizenship, and indeed aims precisely to address the many ways in which full equality and citizenship are denied to minorities.

J. Rex and G. Singh describe two opposing views on multiculturalism. "The soft look" is illustrated by a favorable phrase often used by politicians: "We now live in a multicultural society". Multiculturalism according to that statement is viewed as a natural continuation of liberal democracy and democratic values of tolerance and respect for diversity. Conversely, the "hard look" views multiculturalism, with its emphasis on the group over the individual, as a threat to liberal and democratic values and, therefore, believes that economic migrants or political migrants and refugees can be regarded as threatening the unity of society ${ }^{7}$. At the same time, most experts are inclined to some "middle point of view" that views multiculturalism, or at least the recognition and tolerance of different expressions of culture, as one, perhaps the only possible mean for Western countries in order to cope with the problems arising in regard to globalization, mass immigration and increasing number of ethnic minorities within their borders.

All these views can be observed in various degrees in different European countries. For example, Britain is often regarded as the most developed form of multiculturalism, where Britons, at least according to official policy, stand for a society that provides equal status to certain cultural and religious groups without the domination of any culture. UK law allows ensuring the legitimation of a significant number of minorities such as blacks, Asians, Muslims, etc. and even provide special legal protection to the members of such groups. Conversely, France is often perceived as the main supporter of the assimilation of European nations.

Critics often argued that multiculturalism is the segregation and creation of "parallel communities" and it should be replaced by "civic integration"

${ }^{7}$ Rex, J., Singh, G. (2003) Multiculturalism and political Integration in Modern Nation States. International Journal of Multicultural Societies, Vol. 5(1), p. 4. 
approach based on such postulates as linguistic requirements and citizenship tests (Joppke 2004, 2007). Multiculturalism theorists always insisted that multiculturalism for immigrant groups is aimed not at segregation, but at the integration method aimed at fairer inclusion conditions. Thus, there is no significant contradiction at the conceptual level between multiculturalism policy and civic integration policy, and indeed such countries as Canada and Australia always had an effective integration policy alongside with their decades-old multiculturalism policy.

It should be borne in mind that any state policy, including multiculturalism, is mainly implemented through legal instruments. Legal instruments occupy the leading role for the states that declare themselves as legal at the constitutional level. In this regard, the state's legal policy in the field of intercultural relations and those conceptual approaches that are the basis for such a policy are of particular importance. In our opinion, "a human rights-based approach", which essence, content and perspectives will be revealed in the following section of our research, should be the main, systemforming approach for the formation of the legal policy of Ukraine, as well as of other European states.

\section{2. "A Human Rights-Based Approach" to Resolving Intercultural Interaction: Nature, Content, Perspectives for Implementation}

One of the key problems of multiculturalism is the guaranteeing of human rights, in particular the achievement of a public consensus on the totality of human rights, which is mandatory for all members of society regardless of any cultural differences. At the same time, the supporters of consistent multiculturalism pay attention on collective, group human rights, for example, on the right of ethnic and religious groups to observe their customs within the relations between men and women, including the duty of ladies to wear veils and the subordinate position of women in the family. The supporters of the priority of individual human rights are, for example, against discrimination against women, against wearing explicit items of religious affiliation in unreligious schools, etc.

One should admit that the rhetoric of "the right of every culture to selfexpression" can hide not only the tendency to self-isolation, but also possible totalitarian claims. Taking into account the liberal origin of multiculturalism, one may use a shocking at first sight statement: "If the cannibal culture is in no way inferior to the liberal culture, then a liberal should be ready to throw himself under the bus"8.

${ }^{8}$ Lukovskaya D.I. (2007) Problema universal'nosti prav cheloveka [The issue of the universality of human rights]. Istoriya gosudarstva i prava [History of State and Law], no. 12, pp. 32-35 (in Russian). 
It is important to note that multiculturalism, by its very nature, is contrary to the principle of the universality of human rights. Therefore, from the international and legal, constitutional and legal points of view, the search for acceptable solutions should be in moderate versions of multiculturalism that are completely compatible with the very principle of respect for human rights. Accordingly, multiculturalism is not the basis for comprehensive tolerance. In this regard, the official policy of multiculturalism practiced in Canada is preferable, where the Pierre Trudeau government in 1971 held a course for multiculturalism under the slogan "One nation, two languages, many peoples and cultures"9. In 1988, Canada even passed a special Act on multiculturalism, which clearly stated that "multiculturalism highlights the principle of universalism, that is, the thing that unites us is more important than our differences. But multiculturalism is not the basis for the comprehensive tolerance". In accordance with the official policy of multiculturalism in Canada, ethnic differences are admitted and accepted by the state only to the extent when individuals (not groups) can identify themselves with the cultural tradition of their choice, but only if this identification does not violate human rights, the rights of others or the laws of the country ${ }^{10}$.

Unjustified "flirting" of the state with representatives of cultural minorities, especially in the legal sphere, involves extremely negative consequences. Bright examples of this kind are given by O.N. Bublik and D.L. Coleman ${ }^{11}$. So, an American of Japanese descent drowned two young children and tried (unsuccessfully) to commit suicide because of her husband's betrayal - the court admitted these actions as corresponding to the ancient Japanese custom and practically justified her, and charged her to one year of imprisonment, which she spent being under investigation. In accordance to another criminal case, the court acquitted an American of Chinese descent for killing a wife because of her infidelity, finding these actions consistent with the Chinese custom of washing away the shame with blood. In a third criminal case, an American of Laotian descent was kidnapped from her job and forced to have sexual intercourse - a Lao descent immigrant was sentenced to 120 days of imprisonment and 900 dollars of

9 Terborn G. (2001) Mul'tikul'turnye obshchestva. [Multicultural Societies]. Sotsiologicheskoe obozrenie [Sociological Review], vol. 1, no. 1, pp. 50-51 (in Russian).

${ }^{10}$ Cryderman B.K., Fleras A., O'Toole C.N. (1998) Police, Rase and Elhnicity. A Guide for Law Enforcement Officers. Toronto; Vancouver: Butter-worths, p. 20.

${ }^{11}$ Coleman D.L. (1996) Individualizing Justice through Multiculturalism: The Liberals' Dilemma. Columbia Law Review, vol. 96, no. 5, pp. 1093-1167; Bibik O.N. (2012). Vvedenie v kul'turologiyu ugolovnogo prava [Introduction to the Cultural Studies of Criminal Law]. Moscow: Yurlitinform, $352 \mathrm{p}$. 
compensation for the caused damage, as his tribe considered such a way of choosing the bride to be ordinary. It seems that it is hard to imagine more damage to the legal foundations of society, including the principles of equality, legality and the rule of law!

In this regard, we have to refer to the UNESCO Universal Declaration on Cultural Diversity (2001), which proclaims in the Art. 4: "The defence of cultural diversity is an ethical imperative, inseparable from respect for human dignity. It implies a commitment to human rights and fundamental freedoms, in particular the rights of persons belonging to minorities and those of indigenous peoples. No one may invoke cultural diversity to infringe upon human rights guaranteed by international law, nor to limit their scope"12.

We are deeply convinced that the recognition of a certain range of special (group, corporate) rights in any cultural communities should in no way prejudice the universality and fundamental nature of human rights as the fundamental principle of any national legal order. In this regard A.A. Marchenkov fairly notes "in the world, where everything is relative, where everything has shifted from one place to another and is in the constant motion, human rights are a standing point, a system of universal legal and ethical coordinates, where society can determine the degree of its suitability for a civilized, worthy existence. The existence and recognition of the "basic nature" of the values of human rights sort of "restrain" postmodern reality"13. Besides, it should be borne in mind that there are very different ideas in traditional cultures about individual's values in general, and about human rights and freedoms in particular, about the individual's limits of freedom and the limits of his bondage to traditions and religious beliefs; and these representations can not be quickly and easily changed. However, if there is no deep certainty in the society that the rules of the game are the same for everyone, then there won't be mutual trust, which is one of the most essential prerequisites for solidarity.

It should be noted that the problem of ensuring the rights of representatives of cultural minorities in the overwhelming majority of cases is, in fact, not a problem of ensuring the basic rights of a person and citizen, but

${ }^{12}$ UNESCO Universal Declaration on Cultural Diversity. Adopted by the 31 st Session of the General Conference of UNESCO, Paris, 2 November 2001. Retrieved from: http://www.unesco.org/new/fileadmin/MULTIMEDIA/HQ/CLT/pdf/5_Cultural_Diversity_EN.pd $\mathrm{f}$ (accessed 12.11.2019).

13 Marchenkov A.A. (2006) Obrazovanie pravozashchitnoorientirovannykh kommunikativnykh soobshchestv cherez tekst [Formation of human rights-based communication communities through text]. Proceedings of the Prava cheloveka $v$ kontekste rossiyskoy modernizatsii: mezhregional'naya nauchno-prakticheskaya konferentsiya (Russia, Permian, May 17-18, 2006). Retrieved from: http://old.pgpalata.ru/reshr/grow/04.shtml (in Russian) (accessed 12.11.2019). 
rather the matter of the limits and forms of their implementation. Indeed, the ban on riding motorbike without a protective helmet is not so much a restriction of the human right to an individual external image (as part of the right to privacy), but a manifestation of the elementary care about a person's life, taking into account all those dangers associated with traffic. Therefore, a person wearing a turban should clearly define what is more important for him: "purity of the image" or the opportunity to become a biker. Similarly, a Muslim woman has every right to wear a veil, unless the nature of public relations requires a clear identification of a person (photographing for obtaining a passport or other identity document, passing customs and passport control, participation in meetings, demonstrations and other mass actions, etc.). The rejection of the corresponding limits of the exercise of the rights and freedoms by a representative of a particular cultural group is identical with the rejection of the existing legal order. Accordingly, this person is obliged either to measure his behavior to the existing law and order, or to emigrate searching such a law and order that best corresponds to his group (corporate) rights.

Will Kymlicka quite correctly emphasizes that existing theories of "liberal multiculturalism" explicitly or indirectly assume "desecuritized" relations between the state and minorities, that is, these relations are viewed as social policy issues that should normally be resolved within democratic process of making demands, their discussion and making decisions, not as national security issues that go beyond the normal democratic process ${ }^{14}$. However, political and legal practice indicates the opposite: multiculturalism after the events of September 11, 2001, had to co-exist in the context of increasingly "securitized" relations between the state and cultural minorities. Even though terrorism has no nationality, and thousands of immigrants from European countries (English, French, Germans, Russians, etc.) fought within the ISIGS, however, is strongly associated in the public consciousness (largely due to the media's propaganda role) with Muslims and the Arab world, and states are compelled to respond to this in their domestic and foreign policies, in international and legal acts and in national law. Accordingly, the fight for the preservation of cultural identity can not be a cover for the dissemination of views and practices that threaten the democratic system and universally recognized human rights.

In this regard, it should also be noted that multiculturalism, in its extremely liberal version, which viewed representatives of cultural minorities, including immigrants, as persons who arrived for permanent residence,

${ }^{14}$ Kymlicka W. (2014) The Essentialist Critique of Multiculturalism: Theories, Policies, Ethos. Robert Schuman Centre for Advanced Studies Research Paper no. RSCAS 2014/59, p. 18. Retrieved from: http://dx.doi.org/10.2139/ssrn.2441133 (accessed 12.11.2019). 
socially useful work and loyal to the constitutional system of the hosting state, gradually lost its relevance under the influence of the latest challenges posed by mass illegal migration, transnational crime and international terrorism pretending for own state system. Accordingly, liberal multiculturalism is replaced by rationalized and securitized multiculturalism, which allows to reconcile cultural diversity with national and democratic legal state system, sustainable development and promotion of human rights.

Multicultural societies of the early XXI century, under the influence of mass migration and the flow of special demands based on tolerance for cultural diversity, faced a real threat to the erosion of national identity. And there are many examples of this: a significant increase in the number of Africans among French and Dutch citizens, an excess of mosques over the number of Christian temples in the UK capital, and, of course, the massive spread of "national blocks" (Chinese, Russian, Arab, etc.) in the United States, Canada and the European Union countries. In the context when the share of the "newly arrived" population is steadily increasing due to migration and the "demographic boom" among newcomers, occurring against the background of low birth rates among representatives of the titular nation, each multicultural state will sooner or later faces the dilemma of further national development: whether to preserve national identity formed by centuries of previous historical development, or to follow the "covenants of the ancestors", and, accordingly, to give preference to the policy of "dissolution" of newly arrived cultural minorities, or to continue the policy of multiculturalism, which in the current demographic realities will inevitably change the "status quo" and transform the national identity into a qualitatively new one. It should be noted that such a change in the cultural "status quo" has occurred many times within historical retrospective; it is enough to remember at least how the cultural appearance of the territory of modern Spain has changed from antiquity to the late Middle Ages. Therefore, it is necessary to treat changes in the cultural appearance of the country as an element of the historical process, but the decision must be ultimately made by the people. It is another matter that the choice must be conscious, and science, including jurisprudence, has to play a significant role in this matter.

Rationalized multiculturalism implies the creation of an effective organizational and legal mechanism that includes a proper regulatory basis, a branched network of legitimate public authorities and civil society institutions, as well as law enforcement practices that transfer cultural diversity into a sustainable system of justice. At the same time, the regulatory basis of a multicultural society should have several levels, each of them would have commensurate methods of ensuring social order. 
The upper level of normative regulation is made up by the Constitution and other acts of constitutional legislation (including international legal acts that have become part of national legislation), which establish the basis for the legal status of the individual, including the basic (constitutional) rights and freedoms of the individual. And this level, as have already been mentioned, is not only a matter of the national legal order, but also a matter of international obligations of the state. Consequently, this upper level of normative and legal regulation can not be the subject matter of "political bargaining" between the state and cultural communities, however powerful and plural they might be. The basic principle of a person's legal status - is the principle of equality can not be the subject matter to revision.

The medium level of normative regulation is national legislation, special (sectoral) status of certain categories of subjects, not dependent on their cultural self-identification (participants in civil circulation, traffic, criminal justice, etc.). These norms can establish a special procedure of wearing uniform, special ceremonial, rules for handling dangerous substances, etc. Participation of representatives of these or those cultural communities in these legal relations compels them, if necessary, to remove their "cultural mask", subordinating their behavior to the rules that are common to all homogeneous subjects. In case of a contradiction between these norms and the corporate rules of cultural communities, representatives of the latter may simply refuse to participate in the relevant legal relations (to cease the relevant special status) and thus, independently resolve the conflict that has been revealed.

Finally, the third, lower level of normative regulation is the norms that establish the rights of cultural communities (national, linguistic, religious, etc.). Will Kymlicka refers them as "group differentiated rights"15. At the same time, the special status of these groups should correlate with the constitutional status of the individual. If we are talking about the rights of certain socially vulnerable layers of the population (including various kinds of minorities, as well as pensioners, disabled people, the poor, etc.), then the privileges granted to them (as a manifestation of positive discrimination and at the same time social character of the state) should be exclusively compensatory in nature, that is, to ensure equalization of the real situation of this category of persons in comparison with other persons, based on their lower "starting opportunities". A classic example of this kind can be the rights of national minorities, provided for by the Declaration of the Rights of

${ }^{15}$ Kymlicka W. (1989) Liberalism, Community, and Culture. Oxford: Oxford University Press, 290 p. 
Nationalities in Ukraine $(1991)^{16}$ and the current Law of Ukraine "On National Minorities" (1992) $)^{17}$.

It should be added to the foregoing that not every activity of cultural communities is legally significant, and therefore, is the subject of normative and legal regulation. The length of the outerwear, the color of the turban, either to wear a veil or not while staying in the own apartment, - these issues are outside the legal scope and, therefore, are not the subject to legal assessment.

\section{CONCLUSIONS}

The conducted research of the relevant problems of implementing the policy of multiculturalism in the legal plane makes it possible to conclude the following:

1. Despite serious criticism from academic circles, multiculturalism remains the backbone of the development of intercultural relations in developed Western democracies. At the same time, liberal multiculturalism is replaced by realistic, "securitized" multiculturalism, which soundly assesses intercultural relations in terms of national security threats, democratic system and universally recognized human rights.

2. Rationalized multiculturalism implies the creation of an effective organizational and legal mechanism, including a proper regulatory basis, a branched network of legitimate public authorities and civil society institutions, as well as law enforcement practices that transfer cultural diversity into a stable system of justice. At the same time, the regulatory basis of a multicultural society must be complex in nature and include at least three levels: the first - is the constitutional, which is the basis for the fundamentals of legal position of an individual, the second - is the level of national legislation, which enshrines the special (sectoral) status of certain categories of subjects that are independent from their cultural self-identification, and the third - is the level of legislation that enshrines the rights of cultural communities.

3. The recognition of a particular range of special (group, corporate) rights over certain cultural communities should in no way call into question the universalism and fundamentality of human rights as the key pillar of any national system of justice. The problem of guaranteeing the rights of

${ }^{16}$ Deklaracija prav nacionaljnostej Ukrajiny [Declaration of Rights of Nationalities of Ukraine], adopted November 1, 1991. Retrieved from: http://zakon.rada.gov.ua/laws/ show/177112 (accessed 12.11.2019) (in Ukrainian).

${ }_{17}$ Pro nacionaljni menshyny v Ukrajini [About national minorities in Ukraine]: Law of Ukraine of June 25, 1992 no 2494-XII. Retrieved from: http://zakon.rada.gov.ua/laws/show/249412 (accessed 12.11.2019) (in Ukrainian). 
representatives of cultural minorities in the vast majority of cases is not a problem of ensuring basic human and civil rights, but rather the issue on the limits and forms of their realization. The rejection of the relevant limits of realizing the rights and freedoms by a representative of a particular cultural group is identical with the rejection of the existing system of justice.

\section{SUMMARY}

The article deals with relevant problems of legal regulation of intercultural relations arising in the modern multicultural society. The basic approaches to the evaluation of multiculturalism and its influence on the development of democratic rule of law state system are analyzed. As a methodological basis, the author offers to use the so-called "a human rights-based approach", which is to consider certain issues through the prism of guaranteeing human rights as the main criterion for social progress, the main indicator while assessing the level of development of the state and society. It has been noted that the regulatory basis of a multicultural society within such an approach should include three levels: the first - the constitutional one, which establishes the basics for the legal status of an individual, the second - the level of national legislation establishing the special status of certain categories of subjects, independent of their cultural self-identification and the third one - the level of legislation enshrining the rights of cultural communities.

The author has grounded the conclusion that the recognition of a particular range of special (group, corporate) rights over certain cultural communities should in no way call into question the universalism and fundamentality of human rights as the key pillar of any national system of justice, and the problem of ensuring the rights of representatives of cultural minorities is reduced to the issue about the limits and forms of their implementation. Accordingly, each participant of intercultural legal interaction is obliged either to harmonize own behavior with the existing system of justice, or to emigrate in search of such system of justice that best fits his or her group (corporate) rights.

\section{REFERENCES}

1. Mexico City Declaration on Cultural Policies. World Conference on Cultural Policies, Mexico City, 26 July - 6 August 1982. Retrieved from: https://culturalrights.net/descargas/drets_culturals401.pdf (accessed 12.11.2019).

2. Turki plokho integriruyutsya $v$ Germanii [Turks poorly integrate in Germany]. InterRight. April 17, 2010. Retrieved from: http://inright.ru/ news/id_984 (accessed 12.11.2019) (in Russian).

3. Pro kiljkistj ta sklad naselennja Ukrajiny za pidsumkamy Vseukrajinsjkogho perepysu naselennja 2001 roku [About the number and 
composition of the population of Ukraine according to the results of the 2001 All-Ukrainian Population Census]. Retrieved from: http://2001.ukrcensus.gov.ua/results/general/nationality/ (accessed 12.11.2019) (in Ukrainian).

4. Pro stan i tendenciji rozvytku relighijnoji sytuaciji ta derzhavnokonfesijnykh vidnosyn v Ukrajini za 2012 rik: Informacijnyj zvit Ministerstva kuljtury Ukrajiny [On the Status and Trends of the Development of the Religious Situation and State-Confessional Relations in Ukraine in 2012: Information Report of the Ministry of Culture of Ukraine]. Retrieved from: http://www.irs.in.ua/index.php?option=com_content\&view=article\&id=1212 $\% 3 \mathrm{~A} 1 \&$ catid $=51 \% 3$ Astats\&Itemid=79\&lang=uk (accessed 12.11.2019) (in Ukrainian).

5. Charl'z Teylor: "V raznoobrazii mul'tikul'turnogo konteksta budushchee Ukrainy" [Charles Taylor: "In the diversity of multicultural context - the future of Ukraine"]. Zerkalo nedeli Зеркало недели [Mirror of the week]. 2013. Vol. 24. June 26 - July 5. URL: https://zn.ua/socium/charlzteylor-v-raznoobrazii-multikulturnogo-konteksta-buduschee-ukrainy-_.html (accessed 12.11.2019) (in Russian).

6. Eisenberg A. (2006) Equality, trust and multiculturalism. Social Capital, Diversity, and the Welfare State / F. Kay and R. Johnson (eds). Vancouver: University of British Columbia Press, 2006, pp. 67-94.

7. Rex, J., Singh, G. (2003) Multiculturalism and political Integration in Modern Nation States. International Journal of Multicultural Societies, Vol. 5(1), pp. 3-19.

8. Lukovskaya D.I. (2007) Problema universal'nosti prav cheloveka [The issue of the universality of human rights]. Istoriya gosudarstva $i$ prava [History of State and Law], no. 12, pp. 32-35 (in Russian).

9. Терборн Г. Мультикультурные общества. Социологическое обозрение. 2001. № 1. Т. 1. С. 50-51.

10. Cryderman B.K., Fleras A., O’Toole C.N. (1998) Police, Rase and Elhnicity. A Guide for Law Enforcement Officers. Toronto; Vancouver: Butter-worths, $234 \mathrm{p}$.

11. Coleman D. L. (1996) Individualizing Justice through Multiculturalism: The Liberals' Dilemma. Columbia Law Review, vol. 96, no. 5 , pp. $1093-1167$.

12. Bibik O. N. (2012). Vvedenie v kul'turologiyu ugolovnogo prava [Introduction to the Cultural Studies of Criminal Law]. Moscow: Yurlitinform, $352 \mathrm{p}$.

13. UNESCO Universal Declaration on Cultural Diversity. Adopted by the 31st Session of the General Conference of UNESCO, Paris, 2 November 
2001. Retrieved from: http://www.unesco.org/new/fileadmin/MULTIMEDIA/ HQ/CLT/pdf/5_Cultural_Diversity_EN.pdf (accessed 12.11.2019).

14. Marchenkov A.A. (2006) Obrazovanie pravozashchitnoorientirovannykh kommunikativnykh soobshchestv cherez tekst [Formation of human rights-based communication communities through text]. Proceedings of the Prava cheloveka $v$ kontekste rossiyskoy modernizatsii: mezhregional'naya nauchno-prakticheskaya konferentsiya (Russia, Permian, May 17-18, 2006). Retrieved from: http://old.pgpalata.ru/reshr/grow/04.shtml (in Russian) (accessed 12.11.2019).

15. Kymlicka W. (2014) The Essentialist Critique of Multiculturalism: Theories, Policies, Ethos. Robert Schuman Centre for Advanced Studies Research Paper no. RSCAS 2014/59, p. 18. Retrieved from: http://dx.doi.org/10.2139/ssrn.2441133 (accessed 12.11.2019).

16. Kymlicka W. (1989) Liberalism, Community, and Culture. Oxford: Oxford University Press, 290 p.

17. Deklaracija prav nacionaljnostej Ukrajiny [Declaration of Rights of Nationalities of Ukraine], adopted November 1, 1991. Retrieved from: http://zakon.rada.gov.ua/laws/show/1771-12 (accessed 12.11.2019) (in Ukrainian).

18. Pro nacionaljni menshyny $\mathrm{v}$ Ukrajini [About national minorities in Ukraine]: Law of Ukraine no 2494-XII, adopted June 25, 1992. Retrieved from: http://zakon.rada.gov.ua/laws/show/2494-12 (accessed 12.11.2019) (in Ukrainian).

\section{Information about the author:} Vitalii Serohin, Doctor in Law, Professor, Professor at the Constitutional and Municipal Law Department of the School of Law,

V.N. Karazin Kharkiv National University

4, Svobody Sq., Kharkiv, 61022, Ukraine ORCID ID: orcid.org/0000-0002-1973-9310 


\section{PROFESSIONAL AND ETHICAL STANDARDS FOR CIVIL SERVANTS OF INTERNATIONAL INTERGOVERNMENTAL ORGANIZATIONS}

\section{Tetiana Syroid}

\section{INTRODUCTION}

The development of international relations has led to the creation of international intergovernmental organization (hereinafter - IGO), which, as noted by Prof. Franz Liszt, being called to a greater or lesser number of states to manage common interest, are legitimate international agencies by virtue of their international authority ${ }^{1}$. IGOs have an important place on the international scene and, together with states, act as subjects of international law. Modern IGO is a great, well-organized, effective system that promotes certain interests of the founding states. However, it should be noted that each system of government, public authority, or international organization is not just an abstract machine devoid of human subjective factor. Qualified and independent staff plays an essential role in its work. In view of this, international legal regulation of the status and activity of employees of international organizations is intended to ensure the proper level of their capacity, competence and independence ${ }^{2}$.

To address the goal the states deal with, team of skilled employees of the widest possible geographical representation whose activity meets the highest ideals of humanity is needed. Staff is the most important asset of any organization. The IGO staff is international civil servants by their status.

It should be mentioned that the creation of a system of international organizations as specialized bodies of international cooperation after the World War II, was carried out during the existence of some differences between the states. To ensure the high level of independence of the new system, it was necessary to separate sector-oriented activity from the political core of the organization. Thus, a coherent and unified international civil service was created, the activity of which was to be based on common standards, methods and mechanisms for staff that would avoid serious

1 Franz von Liszt. (1909). Mezhdunarodnoe pravo $v$ sistematicheskom izlozhenii [International law in systematic content]. (V.E. Grabar, Trans). Moscow: Tipografiia K. Mattissena [in Russian].

${ }^{2}$ Report of the International Civil Service Commission for the year 2017, A/72/30. (2017). undocs.org. Retrieved from https://undocs.org/en/A/72/30 [in English]. 
inconsistencies in terms of service and competition during recruitment and promote staff mobility within the system. International civil service has undergone significant changes during its development and establishment.

The international civil service is responsible for the implementation of the goals and objectives of the IGOs. It is based on the rich traditions of public administration that have evolved in the member states, traditions based on the principles of competence, integrity, impartiality, independence and prudence. International civil servants are called to serve the ideals of peace, which is the basis for the functioning of modern IGOs, respect for fundamental rights without any distinction, economic and social progress of all countries and of international cooperation. As employees of an IGO, they do not represent the unilateral interests of the state under the instructions they receive, but common interests according to a free personal confidence ${ }^{3}$. They act on behalf of the organization as a whole. IGO's staff promotes the rule of diplomacy in international relations.

Nowadays, the new challenges for states, in particular, terrorism, trafficking in human beings, illegal migration, etc., could not fail to reflect on modern IGOs that should respond in time and adequately to them, correct the directions, approach of their activity, where, undoubtedly, the main burden lies on their employees. In this regard, the international community should make efforts to proper selection and training of its officials and create appropriate conditions (develop, improve the legal framework for their functioning, improve standards of conduct in different circumstances, create an institutional basis for the protection of their personal rights and interests) to fulfill their responsibilities.

Based on the above, the topic of the article is relevant and caters to contemporary needs.

It is worth noting that some issues regarding the legal status of the IGO's staff were considered in scientific works of domestic and foreign scientists devoted to the law of international organizations, including: M. Baimuratov, V. Butkevych, K. Koliar, O. Kuchyk, P. Lukin, M. Mitrofanov, G. Morozov, T. Neshatayeva, V. Seytimova, T. Symonian, A. Fedotov, T. Tsygankov, A. Shulipa and others. The research of such authors as B.B. Butler, F.P. Walters, A. Evans, J. Langrod, D. Owen, J.P. Rennige, and F. Sayershted, became significant achievements in this field. At the same time, the chosen topic requires further research, taking into account the current realities of functioning of IGOs and their staff.

3 Franz von Liszt. (1909). Mezhdunarodnoe pravo $v$ sistematicheskom izlozhenii [International law in systematic content]. (V.E. Grabar, Trans). Moscow: Tipografiia K. Mattissena [in Russian]. 
The purpose of the article is to analyze the provisions of universal and regional acts of IGOs (the UN, WIPO, OSCE, Council of Europe, CIS) containing standards of professional and ethical conduct for civil servants; to define the role of standards in the creation of cohesive management culture of an IGO and their impact on the external activity of organization and adherence to generally accepted principles of international law which is the basis of global stability, protection of values and progressive development; to make relevant conclusions and recommendations.

\section{International universal professional and ethical standards for civil servants of IGOs}

The successful functioning of any IGO requires favorable conditions for staffing. This requires systems, rules and procedures that set a common standard of behavior and activity and ensure that each employee's work contributes to the achievement of common goals and objectives. With respect to the United Nations (hereinafter - the UN), the following objectives have a global character: the maintenance of international peace and security, the development of cooperation between Member States in all spheres, and the promotion and development of respect for human rights and freedoms (p. 165) ${ }^{4}$. The purpose of the Organization is to deprive future generations of the disasters of war and to provide every man, woman and child with the opportunity to live with dignity in freedom. Such highest ideals have not lost their relevance nowadays.

The status of the UN staff is governed by a number of constituent and internal legal acts of the Organization. The UN Charter grants its officials the status of international civil servants, which in turn confers on them the relevant rights and responsibilities (Art. $100 \mathrm{UN}$ Charter) ${ }^{5}$. The behavior of such servants must be in accordance with high ethical standards. For this purpose, international civil servants must be guided by the unique Standards of Conduct for International Civil Service (hereinafter - SCICS), which were originally developed in 1954 by the International Civil Service Advisory Board. The principles and norms enshrined in the document, which came to light in 1954, have stood the test of time and become part of the culture and heritage of international organizations. Of the International Civil Service Commission (hereinafter - ICSC) twice reviewed the SCICS - in 2001 and in 2013. During the development of the latest version of the Standard that was

4 Syroid, T.L. (2017) Vnutrishnia systema vreghuliuvannia sporiv Orghanizatsiyi Obiednanykh Natsiy [Internal Dispute Settlement System of the United Nations]. V.N. Karazin Kharkiv National University Journal, 23, 165-168 [in Ukrainian].

${ }^{5}$ Charter of the United Nations. (n.d.). www.un.org. Retrieved from https://www.un.org/ en/charter-united-nations/index.html [in English]. 
approved by the UN General Assembly A/RES/67/257, ICSC stemmed from the fact that the internal culture of every international organization has its own characteristics, but they face similar ethical problems.

The SCICS is intended to become guidelines for the ethical conduct of employees of international organizations. Not only do they inform, but also inspire officials of international organizations to uphold the highest ethical and moral values. They reflect the philosophical concept behind the international civil service. Standards are a comprehensive codification of rules designed to regulate the various fields of activity of international civil servants, in particular, they establish the guidelines of the international civil service, define the rules governing the official relationship of international civil servants, abuse of office, conflict of interests, disclosure of information, use of the UN resources, role of the secretariats, sets restrictions after the end of international civil service, contains rules on relations between staff and administration, Member States and governing bodies, public relations, the media, the principle of respect for different customs and cultures, rules on safety and security, personal conduct of international civil servants, nonorganizational work and off-duty activity, gifts and awards from sources outside the organization ${ }^{6}$.

The UN Staff Regulations and Rules stipulate that employees should share and adhere to the principles set out in the UN Charter, including the belief in fundamental human rights, dignity and value of the human being and the equality of men and women. Employees should show respect for all cultures; they should not discriminate against any person or group of persons or in any other way abuse the power and powers conferred on them. Employees must ensure a high level of performance, competence, integrity and loyalty. The notion of good faith includes but is not limited to honesty, impartiality, fairness, honesty and truthfulness in all matters pertaining to their work and status (regulation 1.2) ${ }^{7}$. The concept of good faith, with fortified the UN Charter covers all aspects of behavior of an international civil servant and includes such qualities as honesty, truthfulness, impartiality and incorruptibility. These qualities are no less important than the competence and capacity, which are also enshrined in the Charter. Tolerance and understanding are basic human values. They are also fundamental values for international civil servants, who must equally respect everyone without

\footnotetext{
${ }^{6}$ Shulipa O. (2015). Standarty povedinky mizhnarodnyh tsyvilnyh sluzhbovtsiv [Standards of Conduct for the International Civil Servants]. Scientific Journal "Chronicles of KUL», 2, 368-371 [in Ukrainian].

7 Staff Rules and Staff Regulations of the United Nations, ST/SGB/2014/1. (2014). undocs.org. Retrieved from https://undocs.org/en/ST/SGB/2014/1 [in English].
} 
distinction on whatever grounds. Such respect contributes to the creation of such a climate and conditions that meet the common needs (para. 5,6$)^{8}$.

In addition, in order to maintain the impartiality of the international civil service, international civil servants should remain independent of any authority outside the organization. In accordance with their oath of office, they must not solicit or accept instructions from any government, person or other party outside the organization. It should also be emphasized that international civil servants do not represent their national governments or other parties or the leaders of their policies. This rule applies equally to international civil servants who have been seconded by governments and those sent by other parties. International civil servants must always remember that, by adopting the Statute and the relevant legal documents of each organization, Member States and their representatives have undertaken to respect their independent status. Impartiality should be understood as tolerance and restraint, especially with regard to political and religious beliefs. The personal opinions of international civil servants remain intact, however, unlike an individual, they are not allowed to stand or express their views on controversial issues, whether in their personal capacity or as members of a group. This does not mean that international civil servants should abandon their personal political views or national outlook. This, however, means that they must constantly reflect a broad international outlook and a spirit of understanding about the international community as a whole. International civil servants responsible for implementing projects in specific countries or regions may be invited to exercise special caution while maintaining their independence. From time to time they may receive instructions from the receiving State, but such instructions shall not jeopardize their independence. If, at any time, they believe that such instructions threaten their independence, they should consult their managers.

In addition, international civil servants should refrain from providing assistance to third parties in their relations with the organization in cases where this may lead to actual or perceived preferential treatment. This is particularly important in procurement matters or in the negotiation of possible engagement. Occasionally, international civil servants, by virtue of their position or their functions, may, in accordance with the organization's policy, be required to provide information about certain personal assets in order for the organization to be satisfied that there is no conflict of interest. In doing so, organizations must maintain the confidentiality of all such disclosed information and use it only for a specific purpose or in the manner permitted

${ }^{8}$ Standards of Conduct for the International Civil Service. (n.d.). unesdoc.unesco.org. Retrieved from https://unesdoc.unesco.org/ark:/48223/pf0000230879 [in English]. 
by relevant international civil employees. International civil servants should also advise in advance of a possible conflict of interest arising in the course of their duties and consult on mitigation and settlement. They must carry out their duties and conduct their personal affairs so that the public's confidence in their honesty and the integrity of their organization is maintained and strengthened (para. 8-10, 12, 24) .

In case of actual or potential conflict of interests, when as a result of the act or omission, the personal interests of the employee conflict with the performance of his or her official duties and functions or with the requirements of honesty, independence and impartiality shown to the employee as to international civil servant, employee must report such conflict to the head of their unit (regulation $1.2(\mathrm{~m}))^{10}$. Conflicts of interest include circumstances in which international civil employees, directly or indirectly, may not profit properly or allow a third party to benefit improperly through their links with the organization. Conflicts of interest may arise as a result of personal or family business relationships of an employee of an international organization with third parties, individuals, beneficiaries or other parties. Risk factors associated with conflicts of interest can usually arise at two levels: in the form of organizational conflict of interest and in the form of a conflict of personal interests. Organizational conflict of interest arises when, because of other activities or relationships, the organization cannot impartially provide services, the objectivity of the organization when conducting its work is exposed or may be jeopardized, or the organization receives an undeserved competitive advantage. Conflict of personal interests can generally be understood as a situation in which a person's interest conflicts or may conflict with the performance of official duties. In the event of a conflict of interest or the possibility of its occurrence, information about it should be made public, it should be given due attention and it should be regulated in the highest interests of the organization. Issues of conflict of interest can be very sensitive and therefore require careful consideration (para. 23) ${ }^{11}$.

Attention should also be drawn to the fact that all P-1 and above staff are required to submit declarations of income and financial assets at the appointment and with the frequency established by the Secretary-General of

9 Standards of Conduct for the International Civil Service. (n.d.). unesdoc.unesco.org. Retrieved from https://unesdoc.unesco.org/ark:/48223/pf0000230879 [in English].

10 Staff Rules and Staff Regulations of the United Nations, ST/SGB/2014/1. (2014). undocs.org. Retrieved from https://undocs.org/en/ST/SGB/2014/1 [in English].

${ }^{11}$ Resolution adopted by the General Assembly Statute of the United Nations System Staff College in Turin, Italy, A/RES/55/278. (n.d.). documents-dds-ny.un.org. Retrieved from https://documents-dds-ny.un.org/doc/UNDOC/GEN/N00/575/77/PDF/N0057577.pdf?OpenElement [in English]. 
the UN for themselves, their husbands/wives and their children on their content. The income and financial assets declaration shall include information showing that the possession of assets and the economic activities of employees, their spouses and dependent children does not conflict with their official responsibilities or the interests of the UN (regulation $1.2(\mathrm{n}))^{12}$.

An essential guarantee of ensuring the impartiality and independence of the IGO in its relations with other international organizations and states is the provision in its internal regulations of the restriction on the acceptance by employees of honorary titles, awards, services, gifts or monetary remuneration in connection with the performance of official duties. This situation may result in a real or potential conflict of interest and make the organization a debtor to the giver.

Thus, usually small gifts from non-governmental sources that are acceptable in society or as a tribute to tradition are acceptable but should be reported to the head of department or unit. Even when given permission, employees should try not to give the impression that personal gain may not properly affect professional decisions. However, in order to prevent the unfavorable impression of an international civil service, international civil servants should not, without the permission of the administrative manager, accept any honorary titles, awards, gifts, services or material benefits of more than symbolic value, of which there were sources outside the organization. International civil servants should not receive additional payments and other subsidies from governments or from any other sources before, during or after their work in the UN system, if such payments are related to this work $(\text { para. } 50,51)^{13}$.

The Standards also contains provisions that set out the specificities of communication between staff members and the media. Thus, for the effective functioning of the UN the Organization must have public support. In this regard, it is the responsibility of all international civil servants to promote a better understanding of the goals and activity of their organization. This requires that international civil servants are aware of the achievements of their organizations and familiar with the work of the UN system as a whole. International civil servants also do not have to make public their personal complaints or publicly criticize their organizations. International civil servants should always strive to maintain good reputation of the international civil

12 Staff Rules and Staff Regulations of the United Nations, ST/SGB/2014/1. (2014). undocs.org. Retrieved from https://undocs.org/en/ST/SGB/2014/1 [in English].

${ }^{13}$ Resolution adopted by the General Assembly Statute of the United Nations System Staff College in Turin, Italy, A/RES/55/278. (n.d.). documents-dds-ny.un.org. Retrieved from https://documents-dds-ny.un.org/doc/UNDOC/GEN/N00/575/77/PDF/N0057577.pdf?OpenElement [in English]. 
service in accordance with their pledge of loyalty. When communicating with the media, the principle of openness and transparency of information must be respected, this is an effective means of disseminating information about the tasks of organizations. Organizations should provide appropriate guidelines and procedures that should be based on the following principles: international civil servants should proceed on behalf of their organization and should therefore refrain from presenting personal feedback and opinions; under no circumstances should they use the media in their own interest, make public complaints, disclose non-disclosable information, or seek to influence policy decisions made by their organizations (para. 35-38) ${ }^{14}$.

Employees may also be subject to certain restrictions, both during and after the service. Thus, upon completion of UN system work, international civil servants should not improperly use their previous position, including through the unauthorized use or dissemination of classified or confidential information; international civil servants, including those working in procurement services and as procurement staff, should not seek to unduly influence the organization's decisions in the interests or requests of third parties in order to obtain employment with such third parties (para. 26). Employees involved in the procurement process are prohibited from engaging in certain activities after they have stopped working at the UN. We are talking about employees who are dismissed, terminated or retired. The list of activities that constitute "participation in the procurement process" is contained in the bulletin of the Secretary-General ST/SGB/2006/15. These include, in particular, the selection of potential contractors and suppliers, participation in the contracting process. Former employees who have participated in the procurement process at the UN are not allowed to take up employment or accept job offers from any UN contractor or supplier within one year of termination of service. In addition, former employees who participated in the procurement process were banned from using the UN administrative resource for two years ${ }^{15}$.

It is important to emphasize that the United Nations System Staff College (hereinafter - the UNSSC) was established to provide training and continuous training for UN system staff, in particular in the areas of socio-economic development, peace and security and internal governance. The UNSSC is an independent, system-wide institution dedicated to the accumulation and

${ }^{14}$ Resolution adopted by the General Assembly Statute of the United Nations System Staff College in Turin, Italy, A/RES/55/278. (n.d.). documents-dds-ny.un.org. Retrieved from https://documents-dds-ny.un.org/doc/UNDOC/GEN/N00/575/77/PDF/N0057577.pdf?OpenElement [in English].

15 Secretary-General's bulletin Post-employment restrictions, ST/SGB/2006/15. (2006). undocs.org. Retrieved from https://undocs.org/en/ST/SGB/2006/15 [in English]. 
dissemination of knowledge and training to foster coherent governance across the UN system. It provides for the development of strategic civil leadership and management skills for international civil servants to enhance system-wide collaboration in areas within the overall competence of different organizations; increase of efficiency of activity; strengthen cooperation with Member States and specialized agencies, regional commissions, nongovernmental organizations and civil society in order to create more coherent system-wide governance. The UNSSC operates in light of the needs expressed by the institutions of the UN system and in close cooperation with vocational training institutes (Art. 1, 2) ${ }^{16}$.

Employees should also possess the necessary level of professional skills. Annex II to the ICSC Report A/57/30 "Basic Professional Qualification for Senior Leadership" identifies qualities such as the ability to manage the transformation process; ability to maximize the potential of employees; ability to be driven by results; ability to establish partnerships; communicative; prudence and decision-making skills and more.

Thus, the ability to manage the transformation process is a professional quality that encompasses the ability to evaluate prospects and develop strategy in broad context of the organization's objectives and global contexts, including program goals, priorities, values and other factors. This ability also includes the ability to create a work environment that encourages creativity, a sense of commitment and perseverance, even in adverse circumstances, persuading others to adopt an innovative approach.

The ability to maximize the potential of employees is to be able to inspire, engage, and direct others to achieve goals of shared mission. Such professional quality also includes the ability to set an example for imitation, to foster mutual trust and commitment; create favorable conditions; cooperate with employees on setting realistic expectations in work; respond to what is happening and expect the appropriate response from others; provide mentoring as needed; establish and maintain working relationships characterized by a spirit of cooperation; create a culture that encourages high standards, a spirit of collectivism and a sense of pride.

The ability to be results-oriented should be understood as the willingness to be responsible for the results. A person who is required to possess such professional quality should be able to identify opportunities to improve systems and improve performance; take into account the wishes of customers, as well as the interests of

\footnotetext{
${ }^{16}$ Resolution adopted by the General Assembly Statute of the United Nations System Staff College in Turin, Italy, A/RES/55/278. (n.d.). documents-dds-ny.un.org. Retrieved from https://documents-dds-ny.un.org/doc/UNDOC/GEN/N00/575/77/PDF/N0057577.pdf?OpenElement [in English].
} 
parties and Member States; manage resources under conditions of changing priorities in order to achieve the expected results on time and within budget and quality standards, adjust plans and priorities if circumstances change.

Another core professional skill is the ability to forge partnerships, which includes the ability to forge relationships and strengthen alliances; encourage and support cross-functional and collaborative activities; take into account the broad priorities of the organization and different perspectives; collaborate and find common ground with a wide range of stakeholders; identify and use opportunities to improve work through partnerships. Employee endowed with such a quality must strive for consensus and establish relationships that contribute to the achievement of goals; approach the solution of the problem in order to provide conditions favorable to all; promote, through persuasion and negotiation with the parties, both inside and outside the organization, the achievement of the organization's goals. In addition, communication is an important component of employee professionalism. Such a skill requires the person to be able to explain, propagate and express opinions in a convincing manner; to be an effective advocate of the values of the organization and its tasks; be a careful listener; be attentive to and respond to the problems, needs, and feelings of others; negotiate with individuals and groups, both within and outside the organization; be tactful, listen to the opinions of others; treat people with respect; encourage open exchange of views ${ }^{17}$.

Staff Regulations and Rules of the International Bureau of the World Intellectual Property Organization (hereinafter - the WIPO) provides for the acceptance and signature by the staff of the organizations, prior to the beginning of their official duties, oaths or statements of the following content: "I solemnly swear (alternatively: I confirm, declare, I promise) to perform, with all loyalty and prudence, the functions fully entrusted to me as an employee of the International Bureau, to perform these functions and behave with the sole interests of the International Bureau, in accordance with the Rules of Conduct for International Civil Servants, and do not seek or accept instructions or assistance in the performance of my duties by any government or other body outside the International Bureau". The oath is given (or made) in the presence of the Director-General or an authorized representative of the Director-General and is kept in the employee's personal file. The DirectorGeneral takes an oath before the General Assembly.

The above-mentioned Rules and Regulations also set out the procedure for accepting honors and gifts by employees. No employee shall, without the prior permission of the Director-General, have the right to receive honors, awards,

${ }^{17}$ Report of the International Civil Service Commission, A/57/30. (2002). undocs.org. Retrieved from https://undocs.org/en/A/57/30(SUPP) [in English]. 
services, gifts or awards outside the International Bureau. Permission is granted only where such honors, awards, services, gifts or awards do not contravene the employee's status as an employee of an international organization. The Director-General shall determine the guidelines for the interpretation of this provision by issuing a service instruction. In cases where the Director-General is concerned, the authorization shall be issued by the Coordination Committee. Employees may not offer or promise services, gifts, rewards, or any other personal benefits to other employees or to any third party in order to obtain, refuse to accept or delay any formal decision. Similarly, employees are not entitled to solicit or accept any services, gifts, awards or any other personal benefits from other employees or any third party in exchange for making, refusing to accept or delay any formal decision (regulation 1.8). In addition, employees must not engage in any political activity that is incompatible with their status as an international civil employee or that may affect their independence and impartiality. Membership of employees in political parties is permitted, provided that such membership does not entail actions or obligations to perform actions contrary to the provisions (regulation 1.9).

The WIPO International Bureau's Staff Regulations and Rules prohibit any form of discrimination or harassment, including sexual harassment or harassment on the basis of sex, as well as physical or verbal abuse in the workplace or in connection with the performance of official duties (rule 1.5.1) $)^{18}$.

\section{Professional and ethical standards for civil servants of regional IGOs}

The need for the staff to maintain high standards of professional conduct is also envisaged in the constituent and internal acts of the Council of Europe. Thus, in particular, the Council of Europe Staff Regulations (Part III) ${ }^{19}$ states that in the performance of their duties, staff members must sign, in the presence of the Secretary-General, a declaration stating that such a person "... solemnly declares that he/she is carrying out the duties assigned to him/her as a member of the Council of Europe, in good faith... The Council of Europe's interests will be considered solely in the performance of his/her duties and in official conduct... He/she will not seek or receive any instructions in connection with the exercise of his/her functions by any government, body, organization or persons outside the Council... refrain from doing any actions that could harm moral or material to the Council". Employees must not, without the permission of the Secretary-General, accept directly or indirectly any material or other

\footnotetext{
${ }^{18}$ WIPO International Bureau's Staff Regulations and Rules. (n.d.). www.wipo.int. Retrieved from http://www.wipo.int/export/sites/www/erecruitment/ru/pdf/staff_rules_part_a.pdf [in English].

19 Council of Europe Staff Regulations. (n.d.). publicsearch.coe.int. Retrieved from https://publicsearch.coe.int/Pages/result_details.aspx?ObjectID=090000168078183a [in English].
} 
benefits conferred on them in the performance of their duties. They must exercise high care in the facts and information which they become aware of in course of their duty or in connection with it. Without the permission of the Secretary-General, they must not transmit in any form to any third party any documents or information which have not been made public. This obligation remains in force after the employee has ceased to work.

Employees, who in the performance of their duty, have to deal with issues affecting their personal interests in such a way that this may affect their objectivity, should report this to their immediate supervisor. They should be relieved of responsibility for any matter concerning themselves or their family member (Art. 25, 33-36).

The Council of Europe has developed rules concerning the standards of conduct for members of the Parliamentary Assembly, which have been enshrined in the Code of Conduct for Members of the Parliamentary Assembly of the Council of Europe ${ }^{20}$. It sets out general principles of conduct to be followed by the Assembly members in the performance of their powers, including: honestly, integrity; impartiality. They must make decisions solely in the service of society without being bound by any instructions that would jeopardize compliance with the Code by the staff of the Assembly; use the resources available to them in a responsible manner; promote and uphold the principles set out; adhere to established rules of conduct; etc. (Art. 5).

Standards of conduct for the OSCE officials provided by the Rules of Procedure (Section II Responsibilities and Privileges) ${ }^{21}$, in addition to which the OSCE Code of Conduct for staff/mission members was adopted, which stipulates that OSCE officials should always carry out their activity at the highest personal and professional level, while performing and discharging duty, to represent the OSCE. OSCE officials should not act in such a way that it is likely to discredit the secretariat, institution or mission to which they were assigned, staff and the OSCE as a whole. They must adhere to the OSCE principles, norms and obligations and the mandate of their respective agency or mission (para. 1) 2 $^{22}$ The feature of the Code is a provision that focuses on compliance in the organization of human rights and counter trade and human beings as a material breach of these rights.

In summary, the above appointed acts of the OSCE contain a number of professional and ethical standards of OSCE officials, among them: they

\footnotetext{
${ }^{20}$ Code of conduct for members of the Parliamentary Assembly. (n.d.). website-pace.net. Retrieved from http://website-pace.net/documents/10643/375483/CodeOfConduct-EN.pdf [in English].

${ }^{21}$ OSCE Staff Regulations and Staff Rules. (n.d.). publicsearch.coe.int. Retrieved from https://publicsearch.coe.int/Pages/result_details.aspx?ObjectID=090000168078183a [in English].

22 OSCE Code of conduct for staff/mission members Appendix 1 to the OSCE Staff Regulations and Staff Rules, Permanent Council Decision 550/Corr.1. (2003). www.osce.org. Retrieved from https://www.osce.org/secretariat/31781?download=true [in English].
} 
should behave at any time so as it corresponds to the status of international civil servant; be treated equally and with respect, regardless of gender, race, creed or religion, nationality, ethnic or social background, age, sexual orientation, spouse status or other aspects of personal status; do not have a financial interest in any business if it is related to their official position in the OSCE; do not engage in any activity incompatible with the discharge of his/her duty in the OSCE (do not participate in any paid activity or employment outside the OSCE without the prior approval of the Secretary); do not use, disseminate or publish information that became known to them through their official position; compensate the damages caused to the organization; take care of organization security and more.

Ethical standards should include the following: not using the post for their own personal benefit; not accepting any reward or gift that goes beyond mere politeness. The Secretariat, its institution or mission, its staff/members must not receive any honor, award, commitment or gift in excess of 40 Euros from any government or from any source outside the OSCE without the permission of the Secretary-General and their respective head of institution/mission.

Regulations on civil servants found their consolidation in the Agreement on the Status of the North Atlantic Treaty Organization, National Representatives and International Staff of 1951, where attention is focused generally on the privileges and immunities of employees of various categories ${ }^{23}$.

In the CIS also the attention is paid to the proper level of standards of conduct for employees of the organization, the legal basis for the organization in this area is the Agreement on legal status of officials and the staff of bodies of the CIS of 2003, the Convention on the Inter-Parliamentary Assembly of the CIS of 1995. In particular, the Agreement of 2003 provides that officials and employees of the Commonwealth bodies must not engage in any activity other than scientific, creative and teaching activity (Art. 7) ${ }^{24}$. A special feature of the Commonwealth acts is also the emphasis on the privileges and immunities of the staff of the organization, subject to Art. VII of the Convention on the Privileges and Immunities of the United Nations of 1946 relating to the issuance of passes.

\section{CONCLUSIONS}

An analysis of the provisions of the constituent internal statutes of the IGO on the status of staff gave reason to determine that the distinctive features of an

23 Agreement on the status of the North Atlantic Treaty Organization, National Representatives and International Staff signed in Ottawa. (n.d.). www.nato.int. Retrieved from https://www.nato.int/cps/en/natohq/official_texts_17248.htm? [in English].

${ }^{24}$ Soglashenie o pravovom statuse lits i sotrudnikov organov Sodruzhestva Nezavisimyh Gosudarstv [Agreement on legal status of officials and the staff of bodies of the Commonwealth of Independent States]. (2003). cis.minsk.by. Retrieved from http://cis.minsk.by/reestr/ru/ index.html\#reestr/view/text?doc=1384 [in Russian]. 
international civil servant are loyalty to the organization, fulfillment of international rather than national obligations, compliance with high professional standards, which is a guarantee that the international civil service - an effective instrument to carry out its duties and aspirations of the peoples of the world.

The basic professional standards of conduct for international civil servants envisaged at the universal and regional levels include the following: independence, impartiality, high level of culture, proficiency, international loyalty, non-discrimination, non-disclosure of confidential information, which became a refusal to hold office, ban on past employment, ban on influencing the organization's interests or third party requests, etc.; priority of interests of an IGO. This prevent emergence of conflicting or competing interests that could affect their impartiality.

Ethical standards should include: not accepting honors, awards, service, and gifts outside the organization; prohibition of any form of discrimination or harassment, including sexual harassment or harassment on the basis of sex, as well as physical or verbal abuse in a workplace or in connection with the performance of official duties.

Ensuring compliance with the standards of conduct for the international civil service is aimed at achieving efficiency and maintaining the authority of the IGO. International civil servants must adhere to high values, principles and standards, as they have a primary responsibility for the implementation of the broad ideals they have committed to serve. At the same time, IGOs are obliged to enforce these standards through their regulatory framework, including rules, regulations and other internal administrative acts, and, in addition, by improving the qualification of the staff of the IGO through various forms of trainings, seminars and more.

\section{SUMMARY}

The article analyzes the legal basis (constituent and internal acts) of international intergovernmental organizations of universal and regional nature, in particular: the United Nations, the World Intellectual Property Organization, the Organization for Security and Cooperation in Europe, the Council of Europe, the North Atlantic Treaty Organization, and the Commonwealth of Independent States containing the professional and ethical standards for civil servants. Emphasis is placed on the provisions of universal international instruments, particularly, the Standards of Conduct for International Civil Service, adopted within the UN, which are a comprehensive codification of rules designed to regulate the various fields of activity of international civil servants. It is stated that the provisions laid down in the UN Standards contain general rules of professional ethics for civil servants, which are also enshrined in the acts of international regional organizations. The importance of the United Nations System Staff College 
(UNSSC), which is an independent system-wide institution dedicated to the accumulation and dissemination of knowledge and training, to promote coherent governance culture throughout the Organization is emphasized. The internal acts of the International Bureau of the World Intellectual Property Organization, which contain the relevant norms, are characterized.

Attention is paid to the acts of regional international organizations, the Council of Europe Staff Regulations, the OSCE Rules of Procedure, the OSCE Code of Conduct for staff/mission members, the Agreement on the Status of the North Atlantic Treaty Organization, National Representatives and International Staff, the Agreement on legal status of officials and the staff of bodies of the CIS, to establish the professional and ethical standards of their employees. Emphasis is also placed on special features of the provisions of regional international organizations acts regarding the standards for their employees, for instance, it is noted that the OSCE acts emphasize the observance of human rights and anti-trafficking by employees of the Organization as a material violation of these rights; ensuring the safety of the organization's activity, etc. Relevant conclusions are made.

\section{REFERENCES}

1. Franz von Liszt. (1909). Mezhdunarodnoe pravo v sistematicheskom izlozhenii [International law in systematic content]. (V.E. Grabar, Trans). Moscow: Tipografiia K. Mattissena [in Russian].

2. Report of the International Civil Service Commission for the year 2017, A/72/30. (2017). undocs.org. Retrieved from https://undocs.org/en/ A/72/30 [in English].

3. Syroid, T.L. (2017) Vnutrishnia systema vreghuliuvannia sporiv Orghanizatsiyi Obiednanykh Natsiy [Internal Dispute Settlement System of the United Nations]. V.N. Karazin Kharkiv National University Journal, 23, 165-168 [in Ukrainian].

4. Charter of the United Nations. (n.d.). www.un.org. Retrieved from https://www.un.org/en/charter-united-nations/index.html [in English].

5. Shulipa O. (2015). Standarty povedinky mizhnarodnyh tsyvilnyh sluzhbovtsiv [Standards of Conduct for the International Civil Servants]. Scientific Journal "Chronicles of KUL", 2, 368-371 [in Ukrainian].

6. Staff Rules and Staff Regulations of the United Nations, ST/SGB/2014/1. (2014). undocs.org. Retrieved from https://undocs.org/ en/ST/SGB/2014/1 [in English].

7. Standards of Conduct for the International Civil Service. (n.d.). unesdoc.unesco.org. Retrieved from https://unesdoc.unesco.org/ark:/ 48223/pf0000230879 [in English].

8. Resolution adopted by the General Assembly Statute of the United Nations System Staff College in Turin, Italy, A/RES/55/278. (n.d.). 
documents-dds-ny.un.org. Retrieved from https://documents-dds-ny.un.org/ doc/UNDOC/GEN/N00/575/77/PDF/N0057577.pdf?OpenElement [in English].

9. Secretary-General's bulletin Post-employment restrictions, ST/SGB/2006/15. (2006). undocs.org. Retrieved from https://undocs.org/en/ ST/SGB/2006/15 [in English].

10. Report of the International Civil Service Commission, A/57/30. (2002). undocs.org. Retrieved from https://undocs.org/en/A/57/30(SUPP) [in English].

11. WIPO International Bureau's Staff Regulations and Rules. (n.d.). www.wipo.int. Retrieved from http://www.wipo.int/export/sites/www/ erecruitment/ru/pdf/staff_rules_part_a.pdf [in English].

12. Council of Europe Staff Regulations. (n.d.). publicsearch.coe.int. Retrieved from https://publicsearch.coe.int/Pages/result_details.aspx? ObjectID=090000168078183a [in English].

13. Code of conduct for members of the Parliamentary Assembly. (n.d.). website-pace.net. Retrieved from http://website-pace.net/documents/ 10643/375483/CodeOfConduct-EN.pdf [in English].

14. OSCE Staff Regulations and Staff Rules. (n.d.). publicsearch.coe.int. Retrieved from https://publicsearch.coe.int/Pages/result_details.aspx? ObjectID=090000168078183a [in English].

15. OSCE Code of conduct for staff/mission members Appendix 1 to the OSCE Staff Regulations and Staff Rules, Permanent Council Decision 550/Corr.1. (2003). www.osce.org. Retrieved from https://www.osce.org/ secretariat/31781?download=true [in English].

16. Agreement on the status of the North Atlantic Treaty Organization, National Representatives and International Staff signed in Ottawa. (n.d.). www.nato.int. Retrieved from https://www.nato.int/cps/en/natohq/official_ texts_17248.htm? [in English].

17. Soglashenie o pravovom statuse lits i sotrudnikov organov Sodruzhestva Nezavisimyh Gosudarstv [Agreement on legal status of officials and the staff of bodies of the Commonwealth of Independent States]. (2003). cis.minsk.by. Retrieved from http://cis.minsk.by/reestr/ru/index.html\# reestr/view/text?doc=1384 [in Russian].

\section{Information about the author: Tetiana Syroid, D.J.S., Professor,} Head of the Department of International and European Law,

V.N. Karazin Kharkiv National University 4, Svobody Square, Kharkiv, 61022, Ukraine ORCID ID: orcid.org/0000-0002-8165-4078 


\section{SOCIAL AND LEGAL SUPERVISION AND CONTROL FOR COMPLIANCE WITH FACTORY LEGISLATION IN SCIENTIFIC VIEWS OF THE LATE XIX - EARLY XX CENTURY}

\section{Halyna Terela}

\section{INTRODUCTION}

The establishment and development of an institution for supervision and control of labor legislation observance should be considered in general context of legislation system genesis, especially its sectoral components, such as administrative and labor law. This involves a comprehensive study of historical and theoretical section of the issue related to the explaining the legal nature of supervision and control in the labor sector as a form of social control, an objectively existing phenomenon of legal reality that has arisen, transformed and functions as a result of social relations development.

Theoretical cognition is considered in scientific literature as "object's history, ie logic of its development, formation, logic for its "organs" formation, its parts functions, logic of its integrity, logic of its process ..."1. Taking into account that the relations of supervision and control over the labor law observance are regulated in a legal form, and legal regulation is a form of state influence on public relations, it is obvious that clarifying the essential characteristics of supervision and control in statics and due to pricisely historical conditions in dynamics as well. The clarifying is possible according to a framework for a comprehensive genesis study of law institution regarding the genesis of a society, law and state. Following the appropriate remark by M. Miroshnychenko, “... it is necessary to reproduce in a theory of the true history referring to law and legal phenomena as organic aspects of society"2. Actually, the law history itself provides a wide range of information sources that allow scientific criteria evaluate social phenomena, theoretical conclusions on a solid basis of facts.

It is known that today there are different models of state supervision and labor inspection control in the world. We set a goal to find out the prerequisites and

${ }^{1}$ Il'in A.Ya.(ex. ed.), Molodcov V.S., Korshunov A.M. (1970) Metodologicheskie problemy sovremennoj nauki [Methodological problems of modern science]. Moscow: Izd-vo Mosk. un-ta. (in Russian), pp. 332-333.

2 Miroshnychenko M.I. (2012) Henezys pravovoi systemy Ukrainy: teoretykometodolohichnyi aspekt [Genesis of the legal system in Ukraine: theoretical and methodological aspect] (Doctor of Science Thesis), Kyiv: Open International University of Human Development «Ukraine», p. 87. 
peculiarities for the emergence of factory institution inspection as a specialized state body, designed to supervise and control the compliance with (labor, industrial) legislation; identify views as for the place and role of supervision and control in securing the rights of workers from the imperial period at the example of Ukraine, which in the late XIX - early XX centuries was divided between Russian and Austro-Hungarian empires.

The social essence of the phenomena in modern scientific literature is understood as "... the ability to serve as a means of meeting the needs (interests) of particular subjects of society" ". Such a feature of the legal phenomenon as "sociality" stems from the fact that the subjects of law are exclusively people and their origins. The emergence of legal norms cannot be imagined without the support of people's interests. The content of interest is based on the totality of human needs and lies in the conscious attitude of the subject to social environment, prerequisites and the necessity to meet such needs ${ }^{4}$.

The so-called "need" conceptual approach, interpreted in the 1980s as "... identifying the historically predetermined specific needs for the subjects of public life and establishing the role, function (potential, and real) of those or other objects, phenomena of such needs satisfaction" "will solve the problems of this study.

\section{Raising the problem on the necessity and limits of state intervention in the relationship between manufacturers and workers}

The establishment of supervision and control in the field of wage labor was accompanied by its organizational and legal form of factory inspection institution at the end of the nineteenth century. The legal system of Ukraine (divided between Russian and Austro-Hungarian empires) was at the stage of "legal centralization and neutralization of conditions for the development of national law" $"$. At the same time, legal practices and traditions were imprinted

${ }^{3}$ Rabinovych P., Lutsiv O. (2017) Verkhovenstvo prava yak omriianyi rezultat zdiisnennia prav liudyny (pidkhody do interpretatsii, kryterii otsiniuvannia) [Rule of law as a dreamy result of the realization of human rights (approaches to interpretation, evaluation criteria)]. Law of Ukraine, no. 3, p. 104.

${ }^{4}$ Honcharova K.V., Ivchuk Yu.Yu., Prylypko S.M., Yaroshenko O.M. (2014) Derzhava ta yii orhany yak subiekty trudovoho prava: teoretyko-prykladnyi narys [The State and its Bodies as Subjects of Labor Law: Theoretical and Applied Outline]. Kharkiv: Pravo. (in Ukrainian), p. 11.

${ }^{5}$ Rabinovych P., Lutsiv O. (2017) Verkhovenstvo prava yak omriianyi rezultat zdiisnennia prav liudyny (pidkhody do interpretatsii, kryterii otsiniuvannia) [Rule of law as a dreamy result of the realization of human rights (approaches to interpretation, evaluation criteria)]. Law of Ukraine, no. 3, p. 104.

6 Miroshnychenko M.I. (2012) Henezys pravovoi systemy Ukrainy: teoretykometodolohichnyi aspekt [Genesis of the legal system in Ukraine: theoretical and methodological aspect] (Doctor of Science Thesis), Kyiv: Open International University of Human Development «Ukraine», p. 188. 
within law enforcement practices. The legal opinion of the scientists at that time evolved, showing the substantiation of law concepts, differentiation of the police state and law-based state features, social nature of law, serving as "...a kind of key to understanding the laws, nature and tendencies of the development of law, which do not disappear with the change of socioeconomic formations, and undergo transformational changes in the process of state development"

The bourgeois revolutions within European countries recognized a number of human and citizen rights and freedoms based on traditional liberal values and defining the limits of state interference in private relations, reflecting the beginning of legal equality period due to the destruction of the feudal system. Léon Duguit explained the general tendency of new social development foundations: "State authority should subordinate to the power of law" .

It is known that the transition to bourgeois relations was delayed in Russian Empire, but this did not prevent the well-known scholars in the field of law and economics from discussing acute problems of further state-legal and social development. Thus, famous lawyer from Kyiv, Head for the Department of Legal Encyclopedia in Imperial University of St. Vladimir from 1871 to 1880 and a mayor ${ }^{9}$ of Kyiv in the period from 1875 to $1879-$ M. Rennenkampff, considering the role of the state in protecting the rights of citizens to prevent cases of "personal defense and lynching", noted the need for the latter to establish general and permanent surveillance measures ${ }^{10}$. The scientist attributed supervising to the measures of administrative protection of rights and laid the responsibility for its implementation upon the police, administrative and public authorities. So highlighting the private, public (state) and interstate law, M. Rennenkampff far-sightedly emphasized that "... time and state understand the meaning, boundaries, and correlation of law parts, so the systematization of law has its history which shows how due to the influence of certain conditions of reality different branches of law gradually

7 Zhyhalkin I.P. (2016) Systema pryntsypiv trudovoho prava $v$ umovakh formuvannia pravovoi doktryny Ukrainy [System of labor law principles in the conditions of legal doctrine in Ukraine formation] (Doctor of Science Thesis), Kyiv: Taras Shevchenko National University of Kyiv, p. 137.

${ }^{8}$ Djugi L. (1909) Social'noe pravo, individual'noe pravo i preobrazovanie gosudarstva [Social law, individual law and state transformation]. Moscow: Izdanie N.N. Klochkova. (in Russian), p. III.

${ }^{9}$ Hlyz Yu. (2013) Miskyi holova Kyieva M. K. Rennenkampf: sproba sotsiolohichnoho portretu [Kyiv Mayor M.K. Rennenkampff: an attempt of a sociological portrait]. Local History, no. 2, p. 191.

${ }_{10}$ Rennenkampf N.K. (1907) Juridicheskaja jenciklopedija [Legal Encyclopedia]. Kyiv; St. Petersburg: Izd. knigoprodavca N.Ya. Ogloblina [Lito-tipogr. T-va I.N. Kushnarev]. (in Russian), p. 202. 
emerged, the content was distributed between them and the relationship was established"11.

Ukrainian scientist, associate professor for the Department of Police Law in Imperial University of Saint Vladimir A. Antonovich, being, first of all, a scientist-economist, opposed the excessive government interference in the development of industry so that not to complicate private enterpreneurship with the measures of "excessive supervision". A. Antonovich emphasized that it is not so important to define a certain framework for the administrative activity of the state, but to establish such interaction between police bodies when it is possible to achieve national welfare, unconceivable, in his opinion, without personal freedom $1^{12}$.

Turning to the problem of rights and freedoms, Russian scientistadministrativist A. Yelistratov emphasized the anarchic essence of "absolute freedom", in his view it is incompatible with the tasks of a public nature assumed by the state, and defined the "right of personal freedom" as a set legal norms that determine the attitude of public authorities to the personal freedom of citizens, including the latter and "the right to work (sphere of economic activity of citizens)" 13 .

Therefore, one of the problems in the legal science, caused by the needs of public practice, was to justify the necessity and limits of state intervention in the relationship between industrialists and workers. There were highlited three main positions as for the so-called labor issue in the literature of that time. Proponents of the individualistic direction were opposed to any state intervention in the industrial sphere, they did not see the need for legal regulation of labor relations. This position prevailed in England for some time, it promoted the development of trade unions and their execution of the function for protecting the workers interests.

Contrary to the individualistic concept, the representatives of another extreme point of view emphasized the need for a comprehensive influence of state institutions on all social relations. V. Lytvynov-Falinsky rightly noted that such a position was most clearly manifested in Russian Empire, an agricultural country with a poorly developed industry and as a consequence:

11 Rennenkampf N.K. (1907) Juridicheskaja jenciklopedija [Legal Encyclopedia]. Kyiv; St. Petersburg: Izd. knigoprodavca N. Ja. Ogloblina [Lito-tipogr. T-va I. N. Kushnarev]. (in Russian), p. 202.

${ }^{12}$ Antonovich A.Ya. (1890) Kurs" gosudarstvennago blagoustroystva (politseyskago prava) [Public Improvement Course (Police Law)]. Kyiv: Tip. V.I. Zavadzkago, Vol. 1 (in Russian), p. 103.

${ }^{13}$ Elistratov A. I. (1910) Uchebnik' russkago administrativnogo prava. Posobie k' lektsiyam [Textbook of Russian administrative law. Lecture Manual]. Moscow: Izdanie O-va Vzaimopomoshchi Studentov-Yuristov Mosk. Universiteta Vol. I. (in Russian), p. 84. 
almost complete lack of individual activity of workers ${ }^{14}$. Factory legislation emerged in European countries when workers were free, in Russian Empire factory legislation was characterized by a shortage of freelance workers ${ }^{15}$.

When setting up a factory inspection in accordance with the Law "On juveniles working in factories, plants and manufactories" adopted on June 1, 1882, its powers were supervisory, albeit narrow in scope, extending to the verification of the labor use and the organization of schooling for juvenile workers. On June 3, 1886, with the adoption of the Law "Rules on Supervision of Factory Industries and Mutual Relations of Manufacturers and Workers", which gave the inspection a status of general supervisory body and enshrined the principle of state intervention, the activities of the latter acquired preventive and patronizing details of internal factory regulations and obligation upon inspectors to prevent inconsistencies and clashes between workers and industrialists by administrative influence. G. Shershenevych summarized the change of legislative policy as to the status of factory inspection from the body for protection the working class against exploitation by the factory owners it turned into the body for the police supervision over the workers loyalty.

The contemporary of the events G. Biletsky thought it was necessary to give factory inspection the powers "... to observe the preservation and integrity of the law - its essence, not its letter" $"$. V. Lytvynov-Falinsky tried to substantiate the feasibility of solving the misunderstandings between workers and industrialists "not formally, but in fairness" 17 with the help of inspection by giving various examples from practice. Such a view expressed by factory inspectors demonstrated the guardianship nature of the inspection activity, combination of its performance for both control and supervisory functions. Inspectors practiced interventions in the domestic affairs of enterprises, guided by "the essence of the law and their own discretion"18.

${ }^{14}$ Litvinov-Falinskiy V. p. (1904) Fabrichnoe zakonodatel'stvo i fabrichnaya inspektsiya $v$ Rossii [Factory legislation and factory inspection in Russia]. St. Petersburg: tip. A. S. Suvorina. (in Russian), p. XVIII.

${ }^{15}$ Shershenevich G.F. (1908) Kurs torgovogo prava. T. I: Vvedenie. Torgovye deyateli [Commercial law course. T. I: Introduction. Trading figures]. St. Petersburg: Izdanie Br. Bashmakovykh. (in Russian), p. 225.

16 Balitskiy G. (1907) Kakaya dolzhna byt' fabrichnaya inspektsiya [The way factory inspection should be]. Moscow. (in Russian), p. 32.

${ }^{17}$ Litvinov-Falinskiy V. p. (1904) Fabrichnoe zakonodatel'stvo i fabrichnaya inspektsiya $v$ Rossii [Factory legislation and factory inspection in Russia]. St. Petersburg: tip. A. S. Suvorina. (in Russian), p. 333-335.

${ }^{18}$ Zav'yalov M. F. (2013) Nadzor i kontrol' za soblyudeniem zakonodatel'stva o trude kak sposoby zashchity trudovykh prav rabotnikov [Supervision and monitoring of compliance with labor laws as the ways to protect labor rights of workers] ( $\mathrm{PhD}$ thesis abstract), Moscow: Institute of Legislation and Comparative Law under the Government of Russian Federation, p. 14. 
Russian Empire of the late nineteenth and early twentieth centuries, despite the increasing number of various regulations was characterized by legal arbitrariness, which was justified by the desire to provide a safe and prosperous living conditions for a person who, "by the way, was regarded as a juvenile, unable to understand what is good or bad for him"19.

L. Tal emphasized the peculiarity of regulating relations between industrialists and workers in Russian Empire. According to L. Tal, state intervention in the activity of industrial enterprises was practiced, but it had a purely external and coercive nature, which prevented the initiative of the concerned social groups. The workers were under "comprehensive care and vigilant supervision of the administration", mechanically submitting to the owners, whose power allegedly borrowed their authority from the state. L. Tal noted that " ... the police point of view prevailed over the social point of view" 20 , acknowledging a large number of special laws on factory industry in Russian Empire. L. Tal summed up "industrial law of this era was... centralized or public law; it brought up the branch of administrative (police) law"21.

The supporters of the optimal interaction for state intervention and public initiative took an intermediate place in the attempts of the urgent labor issue solving. In the early twentieth century factory legislation researcher B. Belikov wrote that even the most intransigent supporters of the individualistic direction of social policy began to recognize the "right and duty of a legislator to interfere in relationship between employers and workers" 22 .

At the end of the nineteenth century, a well-known Russian scientist I. Tarasov stated that the least intervention of the state in the sphere of safety, sanitary norms and factory life would be logical, since ensuring the proper conditions of the latter ones would only help to increase labor productivity. "However, unthoughtful self-interest in the alliance with the dark ignorance put the states in the need in this area, first of all, to start compulsory measures" 23 .

${ }^{19}$ Hrytsenko I. S. (2013) Istorychni peredumovy zaprovadzhennia administratyvnoi yustytsii: ukrainska tradytsiia [Historical Background for Administrative Justice: Ukrainian Tradition]. Administrative law and process, no. 1, p. 107.

${ }^{20}$ Tal' L.S. (1918) Ocherki promyshlennogo prava [Essays on Industrial Labor Law]. Moscow: Moskovskoe nauchnoe izdatel'stvo. (in Russian), pp. 12-13.

${ }^{21}$ Tal' L.S. (1918) Ocherki promyshlennogo prava [Essays on Industrial Labor Law]. Moscow: Moskovskoe nauchnoe izdatel'stvo. (in Russian), p. 6.

${ }^{22}$ Belikov Zh.D. (1914) Zhenshchina $v$ promyshlennoy inspektsii Zapada: $k$ voprosu o vvedenii zhenskoy fabrichnoy inspektsii v Rossii. [A woman in the industrial inspection of the West: on the introduction of a female factory inspection in Russia]. Tver: Tipo-Litografiya M.V. Blinova (in Russian), p. 3.

${ }^{23}$ Tarasov I.T. (1897) Ocherk nauki politseyskago prava [Essay on the Science of The Police Law]. Moscow: Visochayshe utverzhd. T-stvo «Pechatnya S.P. Yakovleva». (in Russian), p. 677. 
State attitude change toward the labor issue was clearly imprinted. The concentration processes of production and capital, which began in the 80-ies of the nineteenth century, developed during economic crisis of 1900-1903 and reached their climax during $\mathrm{WWI}^{24}$. The state emerged as an economic entity in such sectors of the economy, which were considered to be an exclusively private sphere. As a consequence, on the one hand, it was a prerequisite for an anti-individualistic attitude to contractual freedom, and on the other hand - a prerequisite for the socialization idea for civil law emergence, ie, the prevailing interests of the whole society over the interests of its individual members and thus state interference justification within the freedom of contractual relationship in individual cases but also as a "socio-political principle that should be laid in a basis of the legal system" 25 .

\section{Prerequisites for factory inspection institution establishment}

The emergence of factory legislation was largely driven by social factors, among which there were the demands of workers to reduce the level of exploitation of their labor ${ }^{26}$. The interestss of people stipulated the emergence of legislation for their labor protection.

Workers' strikes first swept in 1875-1882 in Yuzivka, Orekhovo-Zuev, St. Petersburg, Warsaw, Narva, then in 1884 - early 1885 in Moscow and Vladimir provinces, forced the government to analyze their causes. As a result, it was found that the prerequisites for factory uproar were not accidental in nature and were caused by improper relations between manufacturers and workers: breach of employment conditions; reduction of wages; fines that were unjustifiably imposed on workers and amounted to up to 40 percent of wages; obligation to buy goods within the factory at inflated prices, etc ${ }^{27}$. The result of the investigation was introduction of the draft "Rules on the supervision over the establishments dealing with factory industry and on the relations between the owners and their workers" for the

24 Mashkin O.M. (2010) Monopolizatsiia kapitalistychna [Capitalist Monopolization] Entsyklopediia istorii Ukrainy [Encyclopedia of Ukrainian history], vol. 7. Kyiv: V-vo «Naukova dumka». Retrieved from: http://www.history.org.ua/?termin=Monopolizatsiia_kapitalistychna (accessed 10 October 2019).

25 Kaminskaya P.D. (1927) Sovetskoe trudovoe pravo: obzor deystvuyushchego zakonodatel'stva s prakticheskim komentariem [Soviet labor law: a review of existing legislation with practical comment]. Kharkiv: Yurid. izd-vo Narkomyusta USSR (in Ukrainian), p. 25.

${ }^{26}$ Biriukova A. (2016) Okremi pytannia stanovlennia ta rozvytku trudovoho zakonodavstva v Ukraini [Some issues of formation and development of labor legislation in Ukraine]. Entrepreneurship, economy and law, no. 2, p. 66.

${ }^{27}$ Sliozberg' G.B. (1903) Iz tekushchey praktiki Ugolovnogo Kassatsionnogo Departamenta [From the current practice of the Criminal Cassation Department]. Herald of Law, no. 4, pp. 243-244. 
State Council, written by Minister of Finance and Minister of Internal Affairs. The explanatory note for the project stated: "Personal recruitment for labor in factories ... it is entirely within the field of civil relations, interests of the state..., it is a subject to the police improvement; thus, by virtue of its importance for public order, one cannot but enter the area of special concern and supervision of the government" 28 .

Unsatisfactory working conditions in factories became a sign of imminent threat to national security, growing unrest of workers, the need to regulate relations between industrialists and workers in the conditions of serfdom remnants - all this led to the emergence of factory legislation and factory inspection - the body to supervise compliance with the former one by manufactures. One of the Russian leading police law specialists, V. Deryuzhinsky defined factory legislation as a set of rules governing the relationship between businessmen and workers, protecting the interests of the latter from the adverse effects of large-scale production ${ }^{29}$.

Exploring the state of industry and working conditions in Western Europe, Russian economist I. Kulisher, reasonably concluded that the development of factory legislation showed the passage of the same stages in different countries, consistently covering some then other working conditions and working class groups, creating substantially similar norms. Such uniformity of factory legislation, that incidentally embodied the legislation on labor protection was explained by the scientist as the general principles of social development, produced by "economic science and life" and homogeneous throughout the civilized world "principles of morality and hygiene" 30 . This substantiated the attempt to develop the standards aimed at worker labor protection of international level at the end of the nineteenth century. In March 1890, an international conference was held in Berlin with the participation of representatives from fifteen European countries. One of the important decisions made by the participants was the recommendation to subordinate labor legislation supervision to inspectors, independent on both manufacturers and workers ${ }^{31}$.

${ }^{28}$ Sliozberg' G.B. (1903) Iz tekushchey praktiki Ugolovnogo Kassatsionnogo Departamenta [From the current practice of the Criminal Cassation Department]. Herald of Law, no. 4, p. 244.

${ }^{29}$ Deryuzhinskiy V. F. (1917) Politseyskoe pravo: posobie dlya studentov [Police Law: Student Manual]. Petrograd: Senat. tip. (in Russian), p. 478-479.

${ }^{30}$ Kulisher I.M. (1923) Promyshlennost' $i$ usloviya truda na Zapade v XIX stoletii [Industry and working conditions of the West in the 19th century]. Petrograd: Izdatel'stvo Brokgauz Efron (in Russian), p. 229.

${ }^{31}$ Kulisher I.M. (1923) Promyshlennost' $i$ usloviya truda na Zapade v XIX stoletii [Industry and working conditions of the West in the 19th century]. Petrograd: Izdatel'stvo Brokgauz Efron (in Russian), p. 231. 
There are many examples from factory legislation history of different countries, especially the first laws aimed at working hour regulation, which was neglected by manufacturers regarding the prescriptions of their norms. Therefore in a certain period of time there was an enlightment that "laws without their compliance, orders and prohibitions without supervision are powerless and remain only on paper" ${ }^{32}$. Many scientists addressed to law enforcement and its effectiveness at the end of the nineteenth century, ranging from the author of sociological theory of state formation, development and law - Rudolf von Hering with his "implementation is life and truth of the law, is the law itself" ${ }^{33}$ to I. Novgorodtsev, Russian lawyer and philosopher who wrote: "If there are rules and supervision of their implementation, there is law and power or, quoting the old axiom, ubi societas, ibi jus" (law is there, where society is - from Latin. $)^{34}$. P. Obninsky, Russian lawyer and public figure known for defending the interests of workers in Moscow Prisutstvie on factory affairs, paid attention to the same problem in the article "Legal protection of children working in workshops and issues of its nearest future"; the author warned that every law that aims at collective protection of interests, no matter how perfect and predictable it is, retains value as much as it is fulfilled, otherwise turning into a "dead, needless letter of the law" 35 .

Eugene Ehrlich, a well-known Austrian scientist-lawyer, one of the founders for sociology of law, studying the real "living" law of Bukovina, incidentally came to conclusion that the administrative activity of the country was more effective in comparison with the condition of legislation. According to his observations, in the countries with backward legislation and effective work of factory inspection, the labor protection was better organized than in the countries with advanced legislation and poorly developed factory inspection $^{36}$.

${ }^{32}$ Kulisher I.M. (1923) Promyshlennost' i usloviya truda na Zapade v XIX stoletii [Industry and working conditions of the West in the 19th century]. Petrograd: Izdatel'stvo Brokgauz Efron (in Russian), p. 250.

${ }^{33}$ Iering R. (1905) Yuridicheskaya tekhnika [Legal Technique] St. Petersburg. (in Russian), p. 18.

${ }^{34}$ Novgorodtsev P.I. (1917) Vvedenie v filosofiyu prava. III: Ob obshchestvennom ideale [Introduction to the philosophy of law. III: On the social ideal]. Vol. I. Moscow: Tipo-litografiya T-va I.N. Kushnerev i K. (in Russian), p. 458.

${ }^{35}$ Obninskiy p. N. (1890) Yuridicheskaya okhrana detey, rabotayushchikh v masterskikh, i voprosy ee blizhayshego budushchego [Legal protection of children working in workshops and issues of its near future] Legal messenger, vol. V, no. 5-6, p. 181.

${ }^{36}$ Il'inskiy I.D. (1925) Pravo i byt [Law and Life]. Leningrad; Moscow: Gosudarstvennoe izdatel'stvo (in Russian), p. 23. 


\section{The legal nature for supervision and control of compliance with factory legislation}

In the scientific literature of the late XIX - early XX centuries, there were made first attempts to define the concepts, essential features, assignments, types and forms of supervision and control of compliance with factory legislation. It is worth agreeing with the repeatedly expressed opinion of scientists that both supervision and control are multifaceted categories, and the definition of their essential features depends on the point of view regarding the concept of control and supervision as a legal phenomenon for the state and science ${ }^{37}$. Therefore, it is important to find out how surveillance and control have been positioned in general and in compliance with factory legislation by scholars of the imperial period in particular. The administrativist-scientist A. Elistratov extending the regulatory influence of administrative law to the institution of administrative supervision, defined the latter as a "means of ensuring legality in management"38. A. Elistratov identified the following forms of "supervision or control": (1) reporting; (2) audit; (3) continuous surveillance. Thus, the terms "supervision" and "control" were used by the scientist as synonymous words, referring the first and foremost to the notion of supervision from the position of protection function implementation for public law as a way of legality ensuring. Analyzing the "Volumes of reports" from factory inspectors, A. Bykov concluded that they "...characterize the audits of our factory inspection mainly from the formal side", as most of described violation cases "... established for the supervision of formalities" ${ }^{39}$. As a modern Ukrainian scientist D. Arutyunyan rightly remarked, "...at the origins of administrative law science development, the state control was viewed in the same way as a modern vision of its functional side from the position of regulation, information gathering and surveillance (observation)" ${ }^{\text {"40 }}$.

37 Baklan O.V. (2003) Kontrolno-nahliadova diialnist ta administratyvnyi prymus $v$ sferi okhorony pratsi [Supervision and administrative coercion in the field of labor protection]. Kyiv: Poliprom. (in Ukrainian), p. 22.

38 Elistratov A.I. (1914) Osnovnyya nachala administrativnogo prava: Uchebnoe rukovodstvo [Fundamental Principles of Administrative Law: A Training Manual]. Moscow: Izdanie G.A. Lemmana (in Russian), p. 294.

${ }^{39}$ Bykov A.N. (1909) Fabrichnoe zakonodatel'stvo i razvitie ego $v$ Rossii: lektsii, chitannye $v$ Spb. politekhnikume i v Tekhnologicheskom institute v 1908-9 ucheb. Godu [Factory legislation and its development in Russia: lectures delivered in St. Petersburg. Polytechnic and Technological Institute in 1908 - 9 academic year]. St. Petersburg: Tip. «Pravda». (in Russian), p. 267.

${ }^{40}$ Arutiunian D.A. (2016) Derzhavnyi kontrol u sferi vedennia lisovoho hospodarstva v Ukraini: teoretyko-pravovi zasady doslidzhennia [State control in the field of forestry in Ukraine: theoretical and legal bases of the research]. Scientific Bulletin of Kherson State University. Legal Sciences Series, vol. 5, no. 2, p. 9. 
The researcher of commercial and industrial law V. Udintsev distinguished the following types of state supervision: (1) the highest supervision which was carried out by the Chief Prisutstvie of mining and factory affairs; (2) "nearterm" supervision by district factory inspection officers; (3) local supervision by senior inspectors and precinct officers; (4) supervision of the "general police" in the cases provided for by law, namely: supervision of the teenagers work (Art. 124-125 of the Statute of Industry), supervision of compliance with the improvement and order of factories and plants (Art. 148); (5) the police supervision over the cash settlements for workers ${ }^{41}$.

The administrativists-scientists turned to the functional aspects of supervision and control study at the end of the nineteenth and early twentieth centuries. Thus, I. Tarasov emphasized that if a desired requirement for separation of control from management was not observed, the certain rules had to be observed during the implementation, among them: (1) controlling bodies should be independent of the controlled ones; 2) result of the control must have legal consequences; (3) supervisory authorities should not be involved in management actions to comply with their orders and regulations, confining themselves to purely controlling functions ${ }^{42}$. The scientist drew attention to the need of extensive supervision and control over public persons and individuals (industrialists, in particular) to ensure public and state interests.

Russia clearly identified and actively manifested the prerequisites for labor law science formation at the turn of the nineteenth and twentieth centuries. The labor scientists, ie, representatives of academic science; factory inspectors; government officials and business representatives, addressed the legal nature of the supervision and control of compliance with factory legislation $^{43}$.

L. Tal said, "the order of an enterprise is normalized by the state in a certain part. So this part constitutes the subject of a legal discipline called labor law, industrial, or social law"44. The study of labor law subject at that time meant the study of labor law formation. V. Litvinov-Falinsky substantiated the complex structure of the subject of labor law, including

${ }^{41}$ Udintsev V.A. (1907) Russkoe torgovo-promyshlennoe pravo [Russian commercial and industrial law]. Kyiv: Tipografiya I. I. Chokolova (in Russian), p. 312-314.

${ }^{42}$ Tarasov I.T. (1910) Lektsii po politseyskomu (administrativnomu) pravu. Tom vtoroy. Obshchaya chast' [Lectures on the police (administrative) law. Volume Two. A common part]. Moscow: Pechatnya A.I. Snegirevoy (in Russian), p. 197.

${ }^{43}$ Lushnikov A.M. (2010) Rossiyskaya shkola trudovogo prava i prava sotsial'nogo obespecheniya: portrety na fone vremeni (sravnitel'no-pravovoe issledovanie) [[Russian school of labor law and social security law: portraits at the background of time (comparative legal study)]. Monografiya: V 2 t. T. 1. Yaroslavl: YarGU (in Russian), p. 18.

${ }_{44}$ Tal' L.S. (1918) Ocherki promyshlennogo prava [Essays on Industrial Labor Law]. Moscow: Moskovskoe nauchnoe izdatel'stvo. (in Russian), p. 2. 
employment relations between an employer and a worker but also control and supervision. He noted that due to factory legislation, hired labor relations were transferred from the field of private civil law to the field of public law ${ }^{45}$. The scientists attributed the regulation of employment and labor, ie, the relationship between workers and owners, based on the contract of personal employment (factory, labor or employment contract) to the subject of factory (labor) legislation. The proper order and improvement, as well as safety in factories and plants, were distinguished as the subject based on the content of Art. 1-2 of the Statute on Industrial Labor (1913 edition). At the same time, factory inspection was entrusted with "supervision of compliance with the rules governing duties and relationship between manufacturers and workers" (Art. 34, Paragraph 5, of the Statute on Industrial Labor).

L. Tal described supervision as "the only guarantee, recognized by our law," the application of legislative regulations adopted to restrain manufacturer's power and improve working conditions ${ }^{46}$. Criticizing the position of those scientists who attributed the contractual obligations to life and health protection of workers from harmful production factors, L. Tal justified their other legal nature. Such obligations stemmed from the "Rules on the compensation of casualties due to accidents to workers and employees, as well as members of their families in the enterprises of factory and mining industry" of June 2, 1903, determining the professional risks of a manufacturer, they were of non-contractual, public-law nature ${ }^{47}$. The essence of the new law did not mean to impose the obligation to compensate workers for disability or death on business owners. Such liability was established by general civil laws. The basic importance of this law was the detailed elaboration of the conditions for the implementation of its norms for the injured workers and their right to demand such remuneration ${ }^{48}$.

Thus, the recognition of the workers' right for labor protection and legal obligations laid on employers became the catalyst that caused the establishment and development of supervision (control) institution for compliance with factory (labor) legislation as a way for the rights securing.

45 Lushnikov A.M. (2010) Rossiyskaya shkola trudovogo prava i prava sotsial'nogo obespecheniya: portrety na fone vremeni (sravnitel'no-pravovoe issledovanie [Russian school of labor law and social security law: portraits at the background of time (comparative legal study)]. Monografiya: V 2 t. T. 1. Yaroslavl: YarGU (in Russian), p. 181.

46 Tal' L.S. (1918) Ocherki promyshlennogo prava [Essays on Industrial Labor Law]. Moscow: Moskovskoe nauchnoe izdatel'stvo. (in Russian), p. 12.

47 Tal' L.S. (1918) Ocherki promyshlennogo prava [Essays on Industrial Labor Law]. Moscow: Moskovskoe nauchnoe izdatel'stvo. (in Russian), p. 162.

${ }^{48}$ Shershenevich G.F. (1908) Kurs torgovogo prava. T. I: Vvedenie. Torgovye deyateli [Commercial law course. T. I: Introduction. Trading figures]. St. Petersburg: Izdanie Br. Bashmakovykh. (in Russian), p. 272. 
At that time, the problem of the distinction criteria between public and private law remained a leading issue in scientific community. Proponents of material theory, following Domitius Ulpian took the content of legal relations and interest as the basis. Representatives of the formal theory, following Rudolf von Ehring, saw a fundamental difference in the ways of the rights protection. The third - mixed theory - was based on a combination of both criteria. One way or another, but essentially unanimously attributing the relationship to the protection of workers' rights to public relation, the scientists determined the specifics to protect these rights. Public interest protection was entrusted to the public authorities, initiating this protection, and the latter took place in the context of an administrative or criminal process $^{49}$.

It is significant that during the period of strikes in the run-up to the 19051907 revolution, considering the Smirnov's (factory owner) case of the reduction in workers' wages due to the closure of the factory on non-holiday days and the changing prices which they had allegedly previously agreed with the workers, the Criminal Cassation Department stood up for protection of the workers. The reasoning part of the decision stated that the consent of the victim does not always rule out the crime of the act, namely that the solution of the problem depends on the specifics of the law protected relations whether it is of state importance or concerns only individuals. "There is no doubt", the Court concluded, “... all factory legislation... is of national importance. Only under this condition, factory legislation can have a raison d'être (the reason of being - from French), since it is not possible to speak of the contractual relations freedom in the mutual relations of manufacturers and factory workers with the full economic dependence of the latter on the representatives of capital" ${ }^{\prime 50}$, that is why, - it was justified due to the court decision, - "the whole branch of contractual relations in the interests of the common good is set by law within known limits, the contracting parties are endowed with special rights and duties, their fulfillment is ensured by administrative penalties in accordance with factory inspection order ... and its violation is punishable in accordance with public prosecution order" ${ }^{\prime 51}$.

O. Bykov, having analyzed in detail the development of factory legislation in European countries, concluded that the Austrian model was the most

${ }^{49}$ Khvostov V.M. (1908) Obshchaya teoriya prava. Elementarnyy ocherk [General theory of law. Elementary essay]. Moscow: Sklad izdaniya v knizhnykh magazinakh N.P. Karbasnikova. (in Russian), p. 76.

${ }^{50}$ Sliozberg' G.B. (1903) Iz tekushchey praktiki Ugolovnogo Kassatsionnogo Departamenta [From the current practice of the Criminal Cassation Department]. Herald of Law, no. 4, p. 244.

${ }^{51}$ Sliozberg' G.B. (1903) Iz tekushchey praktiki Ugolovnogo Kassatsionnogo Departamenta [From the current practice of the Criminal Cassation Department]. Herald of Law, no. 4, p. 240. 
similar to the factory inspection system in Russia. An Austrian industrial inspector had to oversee the implementation of the laws, through "benevolent control" to take care of the "implementation of the good points of the law for workers" and at the same time "...with the proper tact to support the manufacturers in their legal requirements, being a fair mediator between the two parties" ${ }^{, 52}$.

\section{CONCLUSIONS}

Thus, in scientific literature of the late XIX - early XX centuries, the need for a comprehensive influence of state institutions referring to all social relations in both Russian and Austro-Hungarian empires occupied the prevailing position. That situation showed the superiority of the police point of view over social one and the corresponding development in the specified period of factory (industrial) legislation as a part of the administrative (police) law. The emergence of factory legislation was largely driven by social factors, among which there were the demands of workers to reduce the level of exploitation of their labor. The interests of people led to the emergence of legislation aimed at protecting their work. Recognition of the workers' rights for labor protection and legal obligations laid on employers has become the catalyst that led to the establishment and development of the institution for supervision (control) of compliance with factory (labor) legislation as a way of ensuring these rights.

The scientific works of the late XIX - early XX centuries show that social purpose of supervision and control was realized through the protection function of public legal interest. The social essence of supervision and control institution was, on the one hand, to protect workers from over-exploitation and unsafe working conditions and, on the other hand, to create an equitable competition for manufacturers.

Supervision and control are multifaceted legal categories, and the definition of their essential features depends on the prevailing in the concept consideration point of view. The administrativists-scientists characterized supervision as a means of ensuring legitimacy in management. On the contrary, the first labor scientists viewed supervision as a guarantee of compliance with the rules of factory legislation.

According to the retrospective analysis, the development of factory legislation during the imperial period was characterized by supervision of its

\footnotetext{
${ }^{52}$ Bykov A.N. (1909) Fabrichnoe zakonodatel'stvo i razvitie ego v Rossii: lektsii, chitannye $v$ $S p b$. politekhnikume $i v$ Tekhnologicheskom institute v 1908-9 ucheb. Godu [Factory legislation and its development in Russia: lectures delivered in St. Petersburg. Polytechnic and Technological Institute in 1908-9 academic year]. St. Petersburg: Tip. «Pravda». (in Russian), p. $123-124$.
} 
implementation, which was realized in a mixed supervisory and control procedure. The governments of both Russian and Austro-Hungarian empires aimed at initial supervision or "benevolent control" over the implementation of factory legislation, interfering in the internal affairs of manufacturers as little as possible. However, under the influence of the labor movement, they had to add to the inspectors' powers broader control and reconciliation functions, which resulted in gaining a patronage nature for the inspection activities.

\section{SUMMARY}

The purpose of this study is to analyze the prerequisites and peculiarities of factory inspection institution as a specialized state body, designed to supervise and control the compliance with (labor, industrial) legislation; characteristics of social and legal aspects for supervision and control based on the analysis of scientific works by the scientists of the imperial period at the example of Ukraine as a part of Russian and Austro-Hungarian empires at the end of the 19th - beginning of the 20th century. The subject of the study is social and legal nature of supervision and control of compliance with factory legislation in historical retrospection. The study determined the predominance position towards a need for a comprehensive influence of state institutions on all public relations in both Russian and Austro-Hungarian empires in scientific literature of the imperial period; superiority of the police point of view over the social point of view; corresponding development of factory legislation as a component of administrative (police) law during a specified period. Social essence of supervising and controlling the compliance with factory legislation has been clarified. Thus, factory legislation, on the one hand, protected workers from over-exploitation and unsafe working conditions and, on the other hand, created an equitable competition for manufacturers. Taking into account the multidimensionality of supervision and control concept. It is emphasized that administratists-scientists characterized supervision as a means of ensuring legality in management. On the contrary to the above mentioned, first labour scientists considered supervision as a guarantee of compliance with the rules of factory legislation. The study proved that the factory legislation development was characterized by supervision over its realization and was implemented in a mixed supervisory and control procedure during the imperial period.

\section{REFERENCES}

1. Il'in A.Ya. (ex. ed.), Molodcov V.S., Korshunov A.M. (1970) Metodologicheskie problemy sovremennoj nauki [Methodological problems of modern science]. Moscow: Izd-vo Mosk. un-ta. (in Russian). 
2. Miroshnychenko M.I. (2012) Henezys pravovoi systemy Ukrainy: teoretyko-metodolohichnyi aspekt [Genesis of the legal system in Ukraine: theoretical and methodological aspect] (Doctor of Science Thesis), Kyiv: Open International University of Human Development "Ukraine".

3. Rabinovych P., Lutsiv O. (2017) Verkhovenstvo prava yak omriianyi rezultat zdiisnennia prav liudyny (pidkhody do interpretatsii, kryterii otsiniuvannia) [Rule of law as a dreamy result of the realization of human rights (approaches to interpretation, evaluation criteria)]. Law of Ukraine, no. 3, p. 100-106.

4. Honcharova K.V., Ivchuk Yu.Yu., Prylypko S.M., Yaroshenko O.M. (2014) Derzhava ta yii orhany yak subiekty trudovoho prava: teoretykoprykladnyi narys [The State and its Bodies as Subjects of Labor Law: Theoretical and Applied Outline]. Kharkiv: Pravo. (in Ukrainian).

5. Rabinovych P., Lutsiv O. (2017) Verkhovenstvo prava yak omriianyi rezultat zdiisnennia prav liudyny (pidkhody do interpretatsii, kryterii otsiniuvannia) [Rule of law as a dreamy result of the realization of human rights (approaches to interpretation, evaluation criteria)]. Law of Ukraine, no. 3, p. 100-106.

6. Miroshnychenko M.I. (2012) Henezys pravovoi systemy Ukrainy: teoretyko-metodolohichnyi aspekt [Genesis of the legal system in Ukraine: theoretical and methodological aspect] (Doctor of Science Thesis), Kyiv: Open International University of Human Development "Ukraine".

7. Zhyhalkin I.P. (2016) Systema pryntsypiv trudovoho prava v umovakh formuvannia pravovoi doktryny Ukrainy [System of labor law principles in the conditions of legal doctrine in Ukraine formation] (Doctor of Science Thesis), Kyiv: Taras Shevchenko National University of Kyiv.

8. Djugi L. (1909) Social'noe pravo, individual'noe pravo $i$ preobrazovanie gosudarstva [Social law, individual law and state transformation]. Moscow: Izdanie N.N. Klochkova. (in Russian).

9. Hlyz Yu. (2013) Miskyi holova Kyieva M. K. Rennenkampf: sproba sotsiolohichnoho portretu [Kyiv Mayor M.K. Rennenkampff: an attempt of a sociological portrait]. Local History. no. 2, p. 191-196.

10. Rennenkampf N.K. (1907) Juridicheskaja jenciklopedija [Legal Encyclopedia]. Kyiv; St. Petersburg: Izd. knigoprodavca N. Ja. Ogloblina [Lito-tipogr. T-va I.N. Kushnarev]. (in Russian).

11. Rennenkampf N.K. (1907) Juridicheskaja jenciklopedija [Legal Encyclopedia]. Kyiv; St. Petersburg: Izd. knigoprodavca N.Ya. Ogloblina [Lito-tipogr. T-va I.N. Kushnarev]. (in Russian).

12. Antonovich A.Ya. (1890) Kurs" gosudarstvennago blagoustroystva (politseyskago prava) [Public Improvement Course (Police Law)]. Kyiv: Tip. V.I. Zavadzkago, Vol. 1 (in Russian). 
13. Elistratov A.I. (1910) Uchebnik' russkago administrativnogo prava. Posobie $k$ ' lektsiyam [Textbook of Russian administrative law. Lecture Manual]. Moscow: Izdanie O-va Vzaimopomoshchi Studentov-Yuristov Mosk. Universiteta Vol. I. (in Russian).

14. Litvinov-Falinskiy V.P. (1904) Fabrichnoe zakonodatel'stvo $i$ fabrichnaya inspektsiya $v$ Rossii [Factory legislation and factory inspection in Russia]. St. Petersburg: tip. A.S. Suvorina. (in Russian).

15. Shershenevich G.F. (1908) Kurs torgovogo prava. T. I: Vvedenie. Torgovye deyateli [Commercial law course. T. I: Introduction. Trading figures]. St. Petersburg: Izdanie Br. Bashmakovykh. (in Russian).

16. Balitskiy G. (1907) Kakaya dolzhna byt' fabrichnaya inspektsiya [The way factory inspection should be]. Moscow. (in Russian).

17. Litvinov-Falinskiy V.P. (1904) Fabrichnoe zakonodatel'stvo $i$ fabrichnaya inspektsiya $v$ Rossii [Factory legislation and factory inspection in Russia]. St. Petersburg: tip. A. S. Suvorina. (in Russian).

18. Zav'yalov M.F. (2013) Nadzor $i$ kontrol' za soblyudeniem zakonodatel'stva o trude kak sposoby zashchity trudovykh prav rabotnikov [Supervision and monitoring of compliance with labor laws as the ways to protect labor rights of workers] (PhD thesis abstract), Moscow: Institute of Legislation and Comparative Law under the Government of Russian Federation.

19. Hrytsenko I.S. (2013) Istorychni peredumovy zaprovadzhennia administratyvnoi yustytsii: ukrainska tradytsiia [Historical Background for Administrative Justice: Ukrainian Tradition]. Administrative law and process, no. 1 , p. 107-121.

20. Tal' L.S. (1918) Ocherki promyshlennogo prava [Essays on Industrial Labor Law]. Moscow: Moskovskoe nauchnoe izdatel'stvo. (in Russian).

21. Tal' L.S. (1918) Ocherki promyshlennogo prava [Essays on Industrial Labor Law]. Moscow: Moskovskoe nauchnoe izdatel'stvo. (in Russian).

22. Belikov Zh.D. (1914) Zhenshchina $v$ promyshlennoy inspektsii Zapada: $k$ voprosu o vvedenii zhenskoy fabrichnoy inspektsii $v$ Rossii. [A woman in the industrial inspection of the West: on the introduction of a female factory inspection in Russia]. Tver: Tipo-Litografiya M. V. Blinova (in Russian).

23. Tarasov I.T. (1897) Ocherk nauki politseyskago prava [Essay on the Science of The Police Law]. Moscow: Visochayshe utverzhd. T-stvo "Pechatnya S. P. Yakovleva". (in Russian).

24. Mashkin O.M. (2010) Monopolizatsiia kapitalistychna [Capitalist Monopolization] Entsyklopediia istorii Ukrainy [Encyclopedia of Ukrainian history], vol. 7. Kyiv: V-vo "Naukova dumka". Retrieved from: http://www.history.org.ua/?termin=Monopolizatsiia_kapitalistychna (accessed 10 October 2019). 
25. Kaminskaya P.D. (1927) Sovetskoe trudovoe pravo: obzor deystvuyushchego zakonodatel'stva s prakticheskim komentariem [Soviet labor law: a review of existing legislation with practical comment]. Kharkiv: Yurid. izd-vo Narkomyusta USSR (in Ukrainian).

26. Biriukova A. (2016) Okremi pytannia stanovlennia ta rozvytku trudovoho zakonodavstva $\mathrm{v}$ Ukraini [Some issues of formation and development of labor legislation in Ukraine]. Entrepreneurship, economy and law, no. 2, p. 66-70.

27. Sliozberg' G.B. (1903) Iz tekushchey praktiki Ugolovnogo Kassatsionnogo Departamenta [From the current practice of the Criminal Cassation Department]. Herald of Law, no. 4, pp. 231-256.

28. Sliozberg' G.B. (1903) Iz tekushchey praktiki Ugolovnogo Kassatsionnogo Departamenta [From the current practice of the Criminal Cassation Department]. Herald of Law, no. 4, pp. 231-256.

29. Deryuzhinskiy V.F. (1917) Politseyskoe pravo: posobie dlya studentov [Police Law: Student Manual]. Petrograd: Senat. tip. (in Russian).

30. Kulisher I.M. (1923) Promyshlennost' $i$ usloviya truda na Zapade $v$ XIX stoletii [Industry and working conditions of the West in the 19th century]. Petrograd: Izdatel'stvo Brokgauz - Efron (in Russian).

31. Kulisher I.M. (1923) Promyshlennost' i usloviya truda na Zapade $v$ XIX stoletii [Industry and working conditions of the West in the 19th century]. Petrograd: Izdatel'stvo Brokgauz - Efron (in Russian).

32. Kulisher I.M. (1923) Promyshlennost' $i$ usloviya truda na Zapade $v$ XIX stoletii [Industry and working conditions of the West in the 19th century]. Petrograd: Izdatel'stvo Brokgauz - Efron (in Russian).

33. Iering R. (1905) Yuridicheskaya tekhnika [Legal Technique] St. Petersburg. (in Russian).

34. Novgorodtsev P.I. (1917) Vvedenie $v$ filosofiyu prava. III: Ob obshchestvennom ideale [Introduction to the philosophy of law. III: On the social ideal]. Vol. I. Moscow: Tipo-litografiya T-va I.N. Kushnerev i K. (in Russian).

35. Obninskiy P.N. (1890) Yuridicheskaya okhrana detey, rabotayushchikh $\mathrm{v}$ masterskikh, i voprosy ee blizhayshego budushchego [Legal protection of children working in workshops and issues of its near future] Legal messenger, vol. V, no. 5-6, p. 179-188.

36. Il'inskiy I.D. (1925) Pravo i byt [Law and Life]. Leningrad; Moscow: Gosudarstvennoe izdatel'stvo (in Russian).

37. Baklan O.V. (2003) Kontrolno-nahliadova diialnist ta administratyvnyi prymus $v$ sferi okhorony pratsi [Supervision and administrative coercion in the field of labor protection]. Kyiv: Poliprom. (in Ukrainian). 
38. Elistratov A.I. (1914) Osnovnyya nachala administrativnogo prava: Uchebnoe rukovodstvo [Fundamental Principles of Administrative Law: A Training Manual]. Moscow: Izdanie G. A. Lemmana (in Russian).

39. Bykov A.N. (1909) Fabrichnoe zakonodatel'stvo i razvitie ego $v$ Rossii: lektsii, chitannye $v$ Spb. politekhnikume $i v$ Tekhnologicheskom institute v 1908-9 ucheb. Godu [Factory legislation and its development in Russia: lectures delivered in St. Petersburg. Polytechnic and Technological Institute in 1908-9 academic year]. St. Petersburg: Tip. "Pravda". (in Russian).

40. Arutiunian D.A. (2016) Derzhavnyi kontrol u sferi vedennia lisovoho hospodarstva v Ukraini: teoretyko-pravovi zasady doslidzhennia [State control in the field of forestry in Ukraine: theoretical and legal bases of the research]. Scientific Bulletin of Kherson State University. Legal Sciences Series, vol. 5, no. 2, p. 7-11.

41. Udintsev V.A. (1907) Russkoe torgovo-promyshlennoe pravo [Russian commercial and industrial law]. Kyiv: Tipografiya I.I. Chokolova (in Russian).

42. Tarasov I.T. (1910) Lektsii po politseyskomu (administrativnomu) pravu. Tom vtoroy. Obshchaya chast' [Lectures on the police (administrative) law. Volume Two. A common part]. Moscow: Pechatnya A. I. Snegirevoy (in Russian).

43. Lushnikov A.M. (2010) Rossiyskaya shkola trudovogo prava i prava sotsial'nogo obespecheniya: portrety na fone vremeni (sravnitel'no-pravovoe issledovanie) [[Russian school of labor law and social security law: portraits at the background of time (comparative legal study)]. Monografiya: V $2 \mathrm{t}$. T. 1. Yaroslavl: YarGU (in Russian).

44. Tal' L.S. (1918) Ocherki promyshlennogo prava [Essays on Industrial Labor Law]. Moscow: Moskovskoe nauchnoe izdatel'stvo. (in Russian).

45. Lushnikov A.M. (2010) Rossiyskaya shkola trudovogo prava i prava sotsial'nogo obespecheniya: portrety na fone vremeni (sravnitel'no-pravovoe issledovanie [Russian school of labor law and social security law: portraits at the background of time (comparative legal study)]. Monografiya: V 2 t. T. 1. Yaroslavl: YarGU (in Russian).

46. Tal' L.S. (1918) Ocherki promyshlennogo prava [Essays on Industrial Labor Law]. Moscow: Moskovskoe nauchnoe izdatel'stvo. (in Russian).

47. Tal' L.S. (1918) Ocherki promyshlennogo prava [Essays on Industrial Labor Law]. Moscow: Moskovskoe nauchnoe izdatel'stvo. (in Russian).

48. Shershenevich G.F. (1908) Kurs torgovogo prava. T. I: Vvedenie. Torgovye deyateli [Commercial law course. T. I: Introduction. Trading figures]. St. Petersburg: Izdanie Br. Bashmakovykh. (in Russian). 
49. Khvostov V.M. (1908) Obshchaya teoriya prava. Elementarnyy ocherk [General theory of law. Elementary essay]. Moscow: Sklad izdaniya v knizhnykh magazinakh N. P. Karbasnikova. (in Russian).

50. Sliozberg' G.B. (1903) Iz tekushchey praktiki Ugolovnogo Kassatsionnogo Departamenta [From the current practice of the Criminal Cassation Department]. Herald of Law, no. 4, pp. 231-256.

51. Sliozberg' G.B. (1903) Iz tekushchey praktiki Ugolovnogo Kassatsionnogo Departamenta [From the current practice of the Criminal Cassation Department]. Herald of Law, no. 4, pp. 231-256.

52. Bykov A.N. (1909) Fabrichnoe zakonodatel'stvo $i$ razvitie ego $v$ Rossii: lektsii, chitannye $v$ Spb. politekhnikume $i v$ Tekhnologicheskom institute v 1908-9 ucheb. Godu [Factory legislation and its development in Russia: lectures delivered in St. Petersburg. Polytechnic and Technological Institute in 1908-9 academic year]. St. Petersburg: Tip. "Pravda". (in Russian).

\section{Information about the author:}

Halyna Terela,

Candidate of Historical Sciences, Docent, Associate Professor at the Chair of Law, Poltava University of Economics and Trade

3, Koval str., Poltava, 36000, Ukraine ORCID ID: orcid.org/0000-0001-5102-7068 


\section{TERRITORIAL BOUNDARIES OF CRIMINAL JURISDICTION OF UKRAINE}

\section{Oleksandr Zhytnyi}

\section{INTRODUCTION}

The idea about national criminal law as about spatial sphere and at the same time as a tool that serves to protect the most valuable public relations within the country, to maintain international law and order and international cooperation in the field of combating crime, and which can be applied to crimes committed both in the country and abroad, requires detailed legislative regulation of the limits of national criminal law (the research was conducted taking into account jurisdictional rescripts of the Criminal Code (CC) of Ukraine of 2001).

One of the most important aspects of this problem is the consideration of interaction and relationship between the criminal law of the country and the principles and norms of international law. In today's world, law enforcement agencies, when globalization becomes one of the tendencies of modern life in the world and a feature of most social practices (including criminal ones), are increasingly confronted with the need to apply the law to criminal acts committed on the territories of several states. This is due to the development of traditional and the emergence of new forms of transnational crimes, such as international drug crime, cybercrime, terrorism, trafficking in human beings, weapons, organs and tissues of the human body, antiques, stolen cars, etc. Besides, country's international obligations require it to implement the provisions of a number of international conventions on combating certain types of crime into national law. These circumstances require careful regulation by the national criminal law regarding the limits of the state's powers to apply.

\section{National Criminal Jurisdiction in Regard to Crimes Committed on Ukraine's Territory: General Regulation Principles}

Territory is the necessary attribute of the state, the material basis of the life of its people. The Constitution of Ukraine links the assertion of national sovereignty and territorial supremacy of Ukraine with the territory of the state (Article 3$)^{1}$. According to J. Brownlie, "The legal competence of states and the norms of their

${ }^{1}$ Konstytutsiia Ukrainy [Constitution of Ukraine]. 1996, June 28. Vidomosti Verkhovnoi Rady Ukrainy - Bulletin of the Verkhovna Rada of Ukraine. Kyiv: Parlam. vyd-vo [in Ukrainian]. 
protection depend on the presence and presuppose the existence of a stable, physically bounded territorial and political organism (homeland)",2.

The main principle of criminal jurisdiction is the fact that the state owns it fully within its territory. The legislation of Ukraine correlates to the territorial principle of the validity of the criminal law in space: all persons committed crimes on the territory of Ukraine are liable on the basis of the Criminal Code of Ukraine (Part 1 of the Art. 6 of the Criminal Code). It expresses the well-known idea of applying the law of the crime scene to the person who committed the crime.

The criminal law literature of Ukraine refers to several groups of objects, which are under the Criminal Code of Ukraine. The first group is objects that are part of the territory of Ukraine (for example, land within the state border of Ukraine). The second is objects that are not geographically within the territory of Ukraine but are equal to it (for example, warships or boats that navigate under the flag of Ukraine). The third is objects and spaces that equate to the territory of Ukraine in cases stipulated by international law (for example, the exclusive (maritime) economic zone of Ukraine) ${ }^{3}$. However, there are differences in the field of criminal science related to the recognition of certain objects that unconditionally belong to the territory of Ukraine or provisionally recognized by Ukraine in the interests of extending the criminal jurisdiction of Ukraine. For example, some attribute the continental shelf to the territory of Ukraine ${ }^{4}$, others call it as the object that is not the territory of Ukraine, but which, under certain conditions provided by international and national law, is within the scope of the Criminal Code of Ukraine ${ }^{5}$, and others do not mention it while revealing the constituent territories of Ukraine ${ }^{6}$.

2 Brounli, Ya. (1977). Mezhdunarodnoe pravo [International law]. Moskov: Progress [in Russian], p. 174.

${ }^{3}$ Malyarenko, V.T., Stashis, V.V., Taciy, V.Y. (Eds.). (2004). Kryminalnyi kodeks Ukrainy: naukovo-praktychnyi komentar [Criminal code of Ukraine: scientific and practical commentary]. Kharkiv: Odyssey [in Ukrainian], p. 20-22; Melnyk, M.I., Khavroniuk, M.I. (Eds.). (2008) Naukovo-praktychnyi komentar do Kryminalnoho kodeksu Ukrainy [Scientific and Practical Commentary to the Criminal Code of Ukraine]. Kyiv: Yurydychna dumka Legal Opinion[in Ukrainian], p. 24-26; Andrushko, P.P. Honcharenko, V.H., Fesenko, Ye.V. (Eds.) (2009). Naukovo-praktychnyi komentar do Kryminalnoho kodeksu Ukrainy [Scientific and Practical Commentary to the Criminal Code of Ukraine]. Kyiv: Alerta ; KNT ; Tsentr uchbovoi literatury [in Ukrainian], C. 30-31.

${ }^{4}$ Melnyk, M.I., Khavroniuk, M.I. (Eds.). (2008) Naukovo-praktychnyi komentar do Kryminalnoho kodeksu Ukrainy [Scientific and Practical Commentary to the Criminal Code of Ukraine]. Kyiv: Yurydychna dumka Legal Opinion[in Ukrainian], p. 24.

${ }^{5}$ Malyarenko, V.T., Stashis, V.V., Taciy, V.Y. (Eds.). (2004). Kryminalnyi kodeks Ukrainy: naukovo-praktychnyi komentar [Criminal code of Ukraine: scientific and practical commentary]. Kharkiv: Odyssey [in Ukrainian], p. 21.

6 Yatsenko, S.S. (Eds.). (2003). Ugolovnyiy kodeks Ukrainyi: nauchno-prakticheskiy kommentariy [Criminal Code of Ukraine: scientific and practical commentary]. Kyiv: A.C.K. [in Ukrainian], p. 12. 
Generalization of the constitutional and administrative legislation of Ukraine, as well as the norms of international law allows to conclude that we should understand the territory of Ukraine in the context of the provisions of the Art. 6 of the Criminal Code, as the natural spaces or artificial objects, where a crime may be initiated, continued, terminated or stopped. These include:

1) the state territory of Ukraine. It is the part of the globe that is under its sovereignty and whose outer borders are marked by the state border of Ukraine. The Law of Ukraine "On the State Border of Ukraine" defines it as a line and a vertical surface running along this line, which define the boundaries of the territory of Ukraine - land, water, subsoil, air space ${ }^{7}$;

2) spaces, natural and artificial objects permanently located outside the boundaries of the state border of Ukraine (continental shelf, exclusive maritime economic zone, submarine cables and pipelines belonging to Ukraine and passing along the bottom outside the territorial waters of any state). They are adjacent to the territory of Ukraine, but they are not part of it. The jurisdiction of Ukraine extends to them within the limits defined by the norms and principles of international law;

3) artificial objects, which due to their mobility, may be located anywhere outside the territory of Ukraine (military and non-military water and air vehicles launched in space by Ukraine), but are equated with it and are under the criminal jurisdiction of the country in accordance with international legal practice, under the flag or sign they stay. Such division of territories of the state is known for a long time. Thus, back in the XIX century specialists distinguished the real territory of the state (land, water, air space above them, which are under the supreme power of the state) and the sham territory, which may be wider or narrower than the real and is determined by international legislation and national law of the country ${ }^{8}$.

Besides, it should be noted that Ukraine, in accordance with the Law of Ukraine dated from April 15, 2014 No. 1207-VII "On Ensuring the Rights and Freedoms of Citizens and Legal Regime on the Temporarily Occupied Territory of Ukraine", officially recognized Autonomous Republic of Crimea as the territory temporarily occupied by the Russian Federation ${ }^{9}$. In this

${ }^{7}$ Zakon Ukrainy Pro derzhavnyi kordon Ukrainy [On the State Border of Ukraine]. (1991, April 4). Vidomosti Verkhovnoi Rady Ukrainy - Bulletin of Verkhovna Rada of Ukraine. Kyiv: Parlam. vyd-vo [in Ukrainian].

${ }^{8}$ Tagantsev, N. S. (1994). Russkoe ugolovnoe pravo [Russian criminal law]. Moskov: Nauka [in Russian], p. 123-124.

${ }^{9}$ Zakon Ukrainy Pro zabezpechennia prav i svobod hromadian ta pravovyi rezhym na tymchasovo okupovanii terytorii Ukrainy [On Ensuring the Rights and Freedoms of Citizens and 
regard, we should follow the provisions of the Convention on the Protection of Civilians during the War dated from 12 August 1949 while dealing the issues of the criminal jurisdiction of Ukraine on this territory. The criminal law of the Occupied Territory in accordance with Part 1 of the Art. 64 of this Convention, remains in force, except cases, when its action is abolished or suspended by the occupying country, if such law constitutes the threat to the security of the occupying country or impedes the implementation of this Convention. In this regard, the Criminal Code of Ukraine is in force and acts concerning the crimes committed on the temporarily occupied territory of Ukraine $^{10}$.

\section{International Regulation of Boundaries and Types of the Country's Territory as a Spatial Basis of National Criminal Jurisdiction}

On the basis of the norms of international law, the criminal jurisdiction of the country extends to objects that are actually located outside this territory. Nowadays, there are generally recognized concepts within international law in regard to the territory, which is understood in the broad sense as the natural spaces of the Earth (land and water, seabed, subsoil), air space in its atmosphere, outer space, celestial bodies, artificial objects and structures (spacecrafts, fixed offshore platforms, etc.) ${ }^{11}$. There are several classifications of territory within international and legal literature. Thus, J. Brownlie distinguishes territorial sovereignty according to the regime of the territory; the territory not covered by the sovereignty of any state or a group of states and having its own status (e.g., trust areas); res nullius; res communis ${ }^{12}$. T. Syroid offered a clearer classification of territories: 1) state territory; 2) international public territory; 3) mixed-regime territory. The state territory means the territory that is under the sovereignty of a particular state, which exercises its territorial primacy within its boundaries. International Public Territory is areas not covered by the sovereignty of any state and which are in the common use of all states under international law (open sea, air space above it, international seabed). Mixed-regime territory is continental shelf, an exclusive economic zone and an adjoining zone - spaces that are not under the

the Legal Regime in the Temporarily Occupied Territory of Ukraine]. (n.d.). zakon3.rada.gov.ua Retrieved from http://zakon3.rada.gov.ua/laws/show/1207-18 [in Ukrainian].

${ }^{10}$ Konventsiia pro zakhyst tsyvilnoho naselennia pid chas viiny [Convention for the Protection of Civilian Persons in Time of War]. (n.d.). zakon5.rada.gov.ua. Retrieved from http://zakon5.rada.gov.ua/laws/show/995_154/print1459194719931410 [in Ukrainian].

11 Buromensky, M.V. (Eds.). (2006). Mizhnarodne pravo [International Law]. Kyiv: Yurinkom Inter [in Ukrainian], C. 94; Baimuratov, M.O. (2002) Mizhnarodne pravo [International Law]. Kharkiv: Odyssey [in Ukrainian], p. 399.

12 Brounli, Ya. (1977). Mezhdunarodnoe pravo [International law]. Moskov: Progress [in Russian], p. 179. 
sovereignty of a particular country, located outside its borders, and which are simultaneously subject to international law (the United Nations Convention on the Law of the Sea of 1982), and, coastal state legislation on some issues ${ }^{13}$. Some other specialists offer a similar classification of territories ${ }^{14}$. M. Baimuratov also includes international streams and channels to the territories with mixed-regime ${ }^{15}$.

International law distinguishes the conditional territory of the state ("quasi-state territory") - it is the territory of diplomatic missions of the state abroad, merchant ships in the high seas, aircrafts and spacecrafts under the flag or sign of this state, underwater pipelines and cables, surface structures in the high seas (above the shelf). Among these objects (also referred to as "floating", "flying", "space" territories, etc.) we distinguish absolute (warships equivalent to the territory of their state) and relative or conditional territory (e.g., transport of the head of a diplomatic mission) ${ }^{16}$.

Thus, the "territorial principle of the validity of the criminal law of Ukraine in space" extends criminal jurisdiction to places that are the state territory of Ukraine and to spaces that are recognized only by international agreements and are under the jurisdiction of Ukraine. However, the Ukrainian legislator covers all these places with the concept of "territory of Ukraine" in violation of the principles and criteria for the classification of territory within international law. Therefore, the Art. 6 of the Criminal Code in the current wording can be regarded as the norm with legal fiction.

Legal fiction is understood as such regulatory prescriptions as enshrined in legal acts and used in legal practice in the form of a specific mean (approach), which is expressed in a conditional declaration of an existing fact or other circumstances that did not actually take place or are not established ${ }^{17}$. Fictions are not something negative in law. Their use is conditioned by the intrinsic

${ }^{13}$ Syroid, T. L. (2005). Mizhnarodne publichne pravo [Public International Law]. Kharkiv: Prometei-Pres [in Ukrainian], p. 75.

${ }^{14}$ Kalmakaryan, R.A., \& Migachev, Y.I. (2004). Mezhdunarodnoe pravo [International law]. Moskov: Eksmo [in Russian], p. 465.

${ }^{15}$ Baimuratov, M.O. (2006) Mizhnarodne pravo [International law]. Sumy: University book; Odessa: Astroprint [in Ukrainian], p. 263; Ignatenko, G.V., \& Tiunov, O.I. (1999). Mezhdunarodnoe pravo [International law]. Moskov: NORMA - INFRA [in Russian], p. 292.

${ }^{16}$ Baimuratov, M.O. (2002) Mizhnarodne pravo [International Law]. Kharkiv: Odyssey [in Ukrainian], p. 411; Matsko, A. (2003) Mizhnarodne pravo [International Law]. Kyiv: MAUP [in Ukrainian], p. 23; Kalmakaryan, R.A., \& Migachev, Y.I. (2004). Mezhdunarodnoe pravo [International law]. Moskov: Eksmo [in Russian], p. 466.

17 Gorshenev, V.M. (1978). Netipichnyie normativnyie predpisaniya v prave [Atypical regulatory requirements in law]. Sovetskoe gosudarstvo $i$ pravo - Soviet state and law, 3. 117-118 [in Russian], p. 117; Tsvik, M.V., Tkachenko, V.D., Petryshyn, O.V. (Eds.). (2002). Zahalna teoriia derzhavy i prava [General theory of state and law]. Kharkiv: Pravo [in Ukrainian], p. 287. 
features of law as a regulator of social relations, in particular, as its property as formal certainty; the basis of the existence of fictions is the mismatch of the legal form and social content. The fictitious norms identify uncertainties for their object of regulation. They give them the forms of legal facts and are an extraordinary technical and legal decision of the legislator ${ }^{18}$. In our opinion, the existence of fictions is not justified in regard to the regulation of territorial jurisdiction within criminal law. It can be removed from the text of the criminal law. There are several reasons for this correction. First of all, the content of the concept of "territory of Ukraine", as previously demonstrated, does not fully correspond to the understanding of the territory of the state in the criminal law (the Art. 6 of the Criminal Code) provided to it in international law. Secondly, the Art. 6 of the Criminal Code does not reflect the fact of the delimitation of the law in space in accordance with the full criminal jurisdiction of Ukraine and limited by such jurisdiction. It is very important issue in view of the mutual respect obligation of the subjects of international relations to the sovereignty and jurisdiction of other subjects. Thus, Ukraine has full, absolute criminal jurisdiction in respect to its state territory (spaces within its state border), in the sense that the crime and punishment of any acts committed in this space are determined in any case by the Criminal Code of Ukraine. However, in such areas as the continental shelf, the exclusive maritime economic zone this jurisdiction is limited ${ }^{19}$. It is applied only to offenses established by international law. In particular it is applied to the issues on realizing the right to biological and mineral resources and to the activities related to the exploration, development and conservation of such resources. Legal relations that arise in this connection are regulated by the laws of Ukraine. Ukraine also exercises national jurisdiction in regard to objects that are within its exclusive (maritime) economic zone (artificial islands, equipment, structures, etc.). In other matters, the norms and principles of international law act on the continental shelf and the exclusive (maritime) economic zone, and in some matters - the norms of law of foreign countries. Thus, according to the Art. 4 of the Law of Ukraine "On the Exclusive (Maritime) Economic Zone of Ukraine" Ukraine has sovereign rights in its exclusive (maritime) economic zone to explore, develop and conserve natural resources both living and inanimate in the waters covering the seabed, on the

\footnotetext{
${ }^{18}$ Panko, K.K. (2004) Metodologiya i teoriya zakonodatelnoy tehniki ugolovnogo prava Rossii [Methodology and theory of the legislative technique of criminal law in Russia]. Voronezh: Publishing house of Voronezh state University [in Russian]. p. 224-228.

${ }^{19}$ Moiseev, O.I. (2007) Kryminalno-pravova yurysdyktsiia Ukrainy shchodo zlochyniv, vchynenykh za yii mezhamy [Criminal Law Jurisdiction of Ukraine on Crimes Committed Outside It]. Extended abstract of candidate's thesis. Kharkiv: Yaroslav Mudryi National Law University [in Ukrainian].
} 
seabed and in its depths, as well as to manage these resources and to undertake other economic exploration and development activities, including the generation of energy through the use of water, streams and wind; the jurisdiction provided by the relevant provisions of this Law and the norms of international law for the creation and use of artificial islands, installations and structures, the conduction of marine scientific research, the protection and conservation of the marine environment; other rights provided by this Law, other legislative acts of Ukraine and generally recognized norms of international $\operatorname{law}^{20}$. According to the wording of the Art. 6 of the Criminal Code, liability under this Code should be incurred for all crimes committed in a place, which this norm recognizes as the territory of Ukraine (including on the continental shelf and in the exclusive (maritime) economic zone). In fact, the jurisdiction of Ukraine in some territories extends only to certain crimes. Thus, if an act, related to the violation the norms and rules of the development and conservation of marine and mineral resources, was committed on board of a foreign vessel being in the economic zone of Ukraine, it may be qualified according to the Criminal Code of Ukraine and its perpetrators - should be responsible under this criminal law (for example, under the Art. 243 of the Criminal Code "Sea Pollution"). If, a foreign sailor on the same territory, causes personal injury to his compatriot, the offense is outside the criminal jurisdiction of Ukraine. This practice is generally accepted ${ }^{21}$.

Thirdly, some objects are considered to be Ukrainian territory only if it is recognized by international law (this statement is applied to quasi-state territory). These are, in particular, space objects launched by Ukraine into space. According to the Art. VIII of the Treaty on the Principles of the Activities of States for the Exploration and Use of Outer Space, including the Moon and Other Celestial Bodies (entered into force on October 10, 1967, for Ukraine - October 31, 1967) a State Member to the Treaty, which register contains the object launched into outer space retains jurisdiction and control over such object and over any crew of that object during their stay in outer space, including on celestial body ${ }^{22}$. Therefore, according to the norms of international space law, the crime and punishment of an act committed on a

${ }^{20}$ Zakon Ukrainy Pro vykliuchnu (morsku) ekonomichnu zonu Ukrainy [On the exclusive (maritime) economic zone of Ukraine]. (1995, Maj 16). Vidomosti Verkhovnoi Rady Ukrainy Bulletin of Verkhovna Rada of Ukraine. Kyiv: Parlam. vyd-vo [in Ukrainian].

${ }^{21}$ Malinin, V.B. (Eds.). (2005). Entsiklopediya ugolovnogo prava [Encyclopedia of Criminal Law]. SPb.: Izdanie professora Malinina [in Russian], P. 188-189.

${ }_{22}$ Dohovir pro pryntsypy diialnosti derzhav po doslidzhenniu i vykorystanniu kosmichnoho prostoru, vkliuchaiuchy Misiats ta inshi nebesni tila [Treaty on the Principles of the Activities of States for the Exploration and Use of Outer Space, including the Moon and Other Celestial Bodie]. (n.d.) zakon4.rada.gov.ua. Retrieved from http://zakon4.rada.gov.ua/laws/show/995_480 [in Ukrainian]. 
spacecraft's board should be determined by the Criminal Code of Ukraine, if it is the state of registration of this object. If there is no such a norm, the surface and interior premises of such a device after leaving the state territory of Ukraine would not be considered as places, where its criminal jurisdiction is exercised.

The same is applied to the so-called "floating" and "flying" quasi-state territory. Thus, the International Convention on the Unification of Certain Rules on Criminal Jurisdiction in Cases of Vessels Collision and Other Incidents Related to Navigation of 1952 stipulates that, in case of a collision or any incident in the field of shipping, which is connected with marine vessels and incurs criminal or any other liability of the captain or other person serving on the vessel, criminal or disciplinary prosecution can be initiated only by the state authorities under whose flag the vessel was at the time of the incident (the Article 1), except cases of collisions and other incidents related to shipping that have occurred in ports, raids or inland waters (the Article 4$)^{23}$. The United Nations Convention on the Law of the Sea (the Art. 97) provides a similar norm for navigation incidents in the high seas ${ }^{24}$.

The International Convention on offenses and certain other actions committed on board aircraft of 1963 establishes a general rule that the state of registration of an aircraft exercises its jurisdiction over criminal offenses and acts that may endanger the safety of the aircraft or persons or property on its board, or which threaten in keeping law and order committed during the flight of such aircraft, or on the surface of the water, or on any other surface outside the territory of any state. At the same time, this rule is not applied to aircrafts used for military, customs or police service ${ }^{25}$.

\section{Perspectives of Improving Normative Regulation of Boundaries of National Criminal Jurisdiction}

As one can see from the above, experts, explaining the opinion of the legislator, expressed in the Art. 6 of the Criminal Code, either have a tendency

${ }^{23}$ Mezhdunarodnaya konventsiya ob unifikatsii nekotoryih pravil ob ugolovnoy yurisdiktsii po delam o stolknovenii sudov i drugih proisshestviy, svyazannyih s sudohodstvom [International Convention on the Unification of Certain Rules on Criminal Jurisdiction in Cases of Collisions and Other Accidents Related to Shipping] (n.d.). zakon1.rada.gov.ua Retrieved from http://zakon1.rada.gov.ua/laws/show/995_564 [in Ukrainian].

${ }^{24}$ Konventsiia Orhanizatsii Obiednanykh Natsii z morskoho prava [The United Nations Convention on Law of the Sea]. (n.d.). zakon4.rada.gov.ua Retrieved from http://zakon4.rada.gov.ua/laws/show/995_057 [in Ukrainian].

${ }^{25}$ Konventsiya o pravonarusheniyah i nekotoryih drugih deystviyah, sovershennyih na bortu vozdushnogo sudna [Convention on Offenses and Certain Other Acts Committed on Board Aircraft]. (n.d.). zakon4.rada.gov.ua. Retrieved from http://zakon4.rada.gov.ua/laws/show/ 995_244 [in Russian]. 
to teleological interpretation of this provision, taking into account the objectives and reasons that led to the creation of this prescription, or apply an extended interpretation of the provisions of the Art. 6 of the Criminal Code in terms of understanding the category of "territory of Ukraine". As a result, the criminal law has actually established the view, which is based on the fact that the jurisdiction of the state has extraterritorial properties to some extent, within the territorial principle of the law on criminal liability in space. Such extraterritoriality exists on the basis of international treaties, the provisions of which are developed within national law. At the same time, teleological interpretation as an aproach of the latter should be applied along to the application of the laws of formal logic, as well as systematic and historical interpretation. In this regard, it should be noted that other norms regulating the validity of the national criminal law in space refer to the commission of a crime "outside" Ukraine (the Articles 7, 8, Part 1 of the Art. 9) and "beyond" Ukraine (the Art. 10 of the Criminal Code). Considering the fact that the boundaries of Ukraine, as noted above, are determined by the state border, then the relevant provisions of these Articles should be interpreted by using the systematic method like "committing a crime beyond (outside) the borders of Ukraine". At the same time, beyond the state border, as also noted above, there are many objects, where the commission of the crime, according to the established understanding of the Art. 6 of the Criminal Code and the territorial principle of the validity of the criminal law in space, is the basis for recognizing the territory of Ukraine as a crime scene. Thus, there is a conflict, where different ways of solving the same issue are established in one institution for national criminal law. For example, if a foreigner commits a crime while staying within Ukraine (territory that does not go beyond the state border), the issue of his liability under the Criminal Code of Ukraine is resolved according to the rules of territorial principle of its validity (the Art. 6 of the Criminal Code). If this person commits a crime outside (beyond the state border) Ukraine, the solution of the issue of the possibility to applyto the Criminal Code of our state to the committed crime is no longer so decisive. At the same time, if we rely on the traditional interpretation of the content of the territorial principle, we should consider the fact whether the crime scene outside Ukraine belongs to objects (territories, spaces) that are under the sovereignty of our state (for example, it is a deck of a warship sailing under the flag of Ukraine) and in the affirmative answer to this question requires to extend the criminal law of Ukraine on the committed action. At the same time, the Art. 8 of the Criminal Code allows to doubt on the correctness of this conclusion, since it states, in particular, that foreigners (as well as stateless persons who do not reside in Ukraine permanently) who have committed crimes abroad are subjects to criminal liability in Ukraine according to the 
Criminal Code in cases stipulated by international treaties. Of course, this can also be understood in such a way that acts committed outside Ukraine (outside its State border) are prosecuted under the Criminal Code of Ukraine only in cases stipulated by international treaties. At the first glance, we can conclude: since the extension of the criminal jurisdiction of Ukraine to certain territories beyond its geographical borders is provided by international treaties (for example, by the provisions of the United Nations Convention on the Law of the Sea on the Immunity of Warships, which means the location of their territories under the criminal jurisdiction of their state, regardless their actual place of stay), then the issue of liability for such crimes should be solved on the basis of the Art. 8 of the Criminal Code. However, this conclusion is contrary to the legal nature of the principle of universal jurisdiction, which (along with the real principle) is enshrined in this norm of national criminal law. We later paid attention to the analysis of the universal principle of the validity of national criminal law in space. Now, let us note that universal jurisdiction is primarily based on the nature of a crime, but not on the nationality of a person or place of the act's commission, and the relevant principle is considered in the world jurisprudence as an important mean of ensuring the inevitability of responsibility for crimes that violate international law and order ${ }^{26}$. Then it is not correct to solve the conflicts between the Art. 6 of the Criminal Code and the Art. 8 of the Criminal Code, referred to in this case, by appealing to the universal principle of the validity of the criminal law in space.

The material stated in previous paragraphs demonstrates that the territorial principle of the validity of the law of Ukraine on criminal liability in space is regulated not only by national law, but also by the norms of international law. At the same time, considering the fundamental importance of the problem for the harmonious functioning of the criminal justice system of Ukraine, there are grounds to conclude that the provisions of the Criminal Code on the spatial limits of the national criminal law in terms of formulating this principle should be clarified. There are several ways to make such clarifications. The first one is to implement the proposition available in scientific research to replace the term of the "territory of Ukraine" in the Art. 6 of the Criminal Code of Ukraine by the phrase "the territory of Ukraine, as well as the territories and objects, which are subjects of the criminal

\footnotetext{
${ }^{26}$ Tkachevsky, Y.M., \& Safarov N.A. Tkachevskiy, Yu. M. (2005). Nekotoryie problemyi primeneniya universalnoy yurisdiktsii $\mathrm{v}$ mezhdunarodnom ugolovnom prave i natsionalnom zakonodatelstve [Some problems of the application of universal jurisdiction in international criminal law and national legislation]. Vesnik Mosk. un-ta. Ser 11. Pravo-Bulletin Mosk. un-ta. Vol. 11. Law, 1, 27-47 [in Russian], p. 31.
} 
jurisdiction of Ukraine in accordance with international law or the laws of Ukraine"27. The disadvantage of this proposition is the need to introduce the category of "criminal jurisdiction of Ukraine" into the text of the criminal law, which has no normative consolidation, is used today only in the doctrine of criminal law and is still under development. The second is to supplement the dispositions of Part 1 of the Art. 6 with the general reference to the norms of international law. This method seems to be unsuitable in terms of practical use. The international and legal system contains hundreds of documents, the research of which may address the executor of law in the course of solving the issue on the possibility to apply the Criminal Code of Ukraine to a crime committed outside its borders. The third - is to restore the list of objects in the disposition of the Art. 6 of the Criminal Code, which according to the norms of international law, are under the criminal jurisdiction of Ukraine in case of committing crimes there. We can see relevant examples in the criminal law of foreign states, where references to international law in some of them specify the content of the territorial principle of the validity of the criminal law in $\operatorname{space}^{28}$. M. Khavroniuk correctly paid attention to this fact in his dissertation research, and demonstrated that the Criminal Codes of many European countries admit crimes committed on the territory of the respective state, if they are committed on territorial waters, air space, on the continental shelf of the state, in its exclusive economy zone, on a ship of this state, at the residence of its diplomatic and consular missions ${ }^{29}$.

As we kmow there are no such provisions in the Criminal Code of Ukraine, although references to the norms of international law are common in the theory of national criminal law, while covering the territorial principle of the validity of the criminal law in space ${ }^{30}$. In this regard, it is appropriate to

${ }^{27}$ Moiseev, O.I. (2007) Kryminalno-pravova yurysdyktsiia Ukrainy shchodo zlochyniv, vchynenykh za yii mezhamy [Criminal Law Jurisdiction of Ukraine on Crimes Committed Outside It] Extended abstract of candidate's thesis. Kharkiv: Yaroslav Mudryi National Law University [in Ukrainian], P. 8, 9.

${ }^{28}$ Zhytnyy, O.O. (2012) Intehratsiia norm mizhnarodnoho prava ta Zahalnoi chastyny natsionalnoho kryminalnoho zakonodavstva (zarubizhnyi dosvid) [Integration of International Law and the Common Part of National Criminal Law (Foreign Experience)]. Naukovyi visnyk Dnipropetrovskoho derzhavnoho universytetu vnutrishnikh sprav - Scientific Bulletin of Dnipropetrovsk State University of Internal Affairs, 2 (59), 361-368 [in Ukrainian], p. 361-368.

29 Khavroniuk, M.I. (2007). Kryminalne zakonodavstvo Ukrainy ta inshykh derzhav kontynentalnoi Yevropy: porivnialnyi analiz, problemy harmonizatsii [Criminal law of Ukraine and other continental European states: comparative analysis, problems of harmonization]. Extended abstract of Doctor's thesis. Kyiv: National Academy of Internal Affairs [in Ukrainian], P. 11.

${ }^{30}$ Stashis, V.V., Taciy, V.Y. (Eds.). (2010). Kryminalne pravo Ukrainy: Zahalna chastyna [Criminal law of Ukraine: Common part]. Kharkiv: Pravo [in Ukrainian], P. 63; Melnyk, M.I., Khavroniuk, M.I. (Eds.). (2008) Naukovo-praktychnyi komentar do Kryminalnoho kodeksu 
cite the position of A. Naumov, who provided the norm in the Theoretical Model of the General Part of the Criminal Code in the draft Article on the territorial principle of the validity of the law in space of the following content: "Liability for a crime committed on an aircraft, sea or river vessel outside the USSR under the flag or sign of the USSR shall come under this Code if a ship assigned to a port is located on the territory of the $\mathrm{USSR}^{31}$. We should pay attention to some provisions of the Model Criminal Code for Member States to the Commonwealth of Independent States (1996), which may be, with some refinement, as models for further improvement of the Art. 6 of the Criminal Code of Ukraine. The draft stipulated, in particular, that the validity of the criminal law of the state extended to crimes committed on its continental shelf or in its exclusive economic zone in cases provided by international treaties (Part 4 of the Art. 13). It also stipulated that a person who had committed a crime on a ship being in the high seas or in the open air was liable under the criminal law of the state, which flag it had, unless otherwise provided by international treaties; a person who had committed a crime on a military river, sea or aircraft of this state, regardless of the place of stay (Part 5 of the Art. 13) was liable under the criminal law of the state ${ }^{32}$. Therefore, in such cases, the norms of international law should be implemented to the norm on the validity of the law in space.

Since the criminal law should provide citizens with information about the limits of what is allowed and should serve as a clear source for law enforcement and judicial agencies of the state, which regulates their activity in the field of criminal justice, in our opinion, we should use the third method out of the offered above, stating the list of objects and spaces in the Art. 6 of the Criminal Code, which are equated to the territory of Ukraine according to the legislation of Ukraine and international law, in case of committing a crime on this territory by any person. Besides, it is advisable to make a general reference to international law there, leaving this list open. It is necessary because there is no possibility to provide the exhaustive list of such objects, and these lists will be changed over time.

Ukrainy [Scientific and Practical Commentary to the Criminal Code of Ukraine]. Kyiv: Yurydychna dumka Legal Opinion[in Ukrainian], P. 25-26.

${ }^{31}$ Kudryavtsev, V.N., Kelina, S.G. (Eds.). (1987). Ugolovnyiy zakon. Opyit teoreticheskogo modelirovaniya [Criminal law. The experience of theoretical modeling]. Moskov: Nauka [in Russian], P. 32.

${ }^{32}$ Modelnyiy ugolovnyiy kodeks dlya gosudarstv - uchastnikov Sodruzhestva Nezavisimyih Gosudarstv [Model Penal Code for the Member States of the Commonwealth of Independent States]. Informatsionnyiy byuleten - Newsletter, 10. Retrieved from http://www.iacis.ru/ $\mathrm{html} /$ ?id=22\&pag=30\&nid=1 [in Russian]. 


\section{CONCLUSIONS}

The conducted study allows to make a number of conclusions and suggestions. Considering the fundamental importance of quality regulation of the national criminal jurisdiction for the harmonious functioning of the criminal justice system of Ukraine and for the implementation of national criminal policy, there are grounds for concluding that it is necessary to clarify the provisions of the Criminal Code on the limits of the validity of the national criminal law (and, accordingly, on the limits of national criminal jurisdiction). In our opinion, the Art. 6 of the Criminal Code has contained the list of the objects and spaces which, according to the legislation of Ukraine and international law, equate to the territory of Ukraine in case of committing a crime there. Besides, it should also contain a general reference to the norms of international law, leaving this list open (it is necessary, since such objects can not be exhaustively enumerated, and these lists will be changed over time).

In regard to the mentioned above, it is offered to have the following wording of the Art. 6 of the Criminal Code:

"The Article 6. Validity of the law on criminal liability according to the crime scene

1. Persons who have committed crimes on the territory within the limits determined by the state border of Ukraine shall be criminally liable under this Code.

2. In cases envisaged by international treaties, where their mandatory consent has been given by Verkhovna Rada of Ukraine, the validity of this Code shall extend to persons, who have committed crimes on the continental shelf of Ukraine or in the exclusive (maritime) economic zone of Ukraine or on other territories, beyond state border of Ukraine.

3. Persons who have committed crimes on a ship assigned to the Ukrainian port shall be criminally liable under this Code, unless otherwise provided in international treaties, where their mandatory consent is provided by Verkhovna Rada of Ukraine. Persons who have committed crimes on a warship assigned to the Ukrainian port shall be criminally liable under this Code.

4. The crime is admitted as committed on the territory specified in paragraphs 1-3 of this Article, if it was started, continued or terminated on this territory.

5. The crime is admitted as committed on the territory specified in paragraphs 1-3 of this Article, if its perpetrator or at least one of the accomplices acted on this territory". 


\section{SUMMARY}

This work contains analysis of the problem of regulating territorial boundaries of criminal jurisdiction. The study has been conducted on the basis of the regulation of the validity of the criminal law in regard to crimes committed in Ukraine. The importance of the territory of the state in criminal law is considered. The content of the territorial principle of the validity of the criminal law of Ukraine in space has been considered. The author has analyzed the regulation of the territory of the state within national and international legal systems. He has pointed out the inconsistency with the principles of establishing the limits of state jurisdiction within international law. A new wording of the Art. 6 of the Criminal Code of Ukraine has been offered.

\section{REFERENCES}

1. Baimuratov, M.O. (2002) Mizhnarodne pravo [International Law]. Kharkiv: Odyssey [in Ukrainian].

2. Baimuratov, M.O. (2006) Mizhnarodne pravo [International law]. Sumy: University book; Odessa: Astroprint [in Ukrainian].

3. Brounli, Ya. (1977). Mezhdunarodnoe pravo [International law]. Moskov: Progress [in Russian].

4. Gorshenev, V.M. (1978). Netipichnyie normativnyie predpisaniya v prave [Atypical regulatory requirements in law]. Sovetskoe gosudarstvo $i$ pravo - Soviet state and law, 3. 117-118 [in Russian].

5. Dohovir pro pryntsypy diialnosti derzhav po doslidzhenniu i vykorystanniu kosmichnoho prostoru, vkliuchaiuchy Misiats ta inshi nebesni tila [Treaty on the Principles of the Activities of States for the Exploration and Use of Outer Space, including the Moon and Other Celestial Bodie]. (n.d.) zakon4.rada.gov.ua. Retrieved from http://zakon4.rada.gov.ua/laws/show/ 995_480 [in Ukrainian].

6. Zhytnyy, O.O. (2012) Intehratsiia norm mizhnarodnoho prava ta Zahalnoi chastyny natsionalnoho kryminalnoho zakonodavstva (zarubizhnyi dosvid) [Integration of International Law and the Common Part of National Criminal Law (Foreign Experience)]. Naukovyi visnyk Dnipropetrovskoho derzhavnoho universytetu vnutrishnikh sprav - Scientific Bulletin of Dnipropetrovsk State University of Internal Affairs, 2 (59), 361-368 [in Ukrainian].

7. Tsvik, M.V., Tkachenko, V.D., Petryshyn, O.V. (Eds.). (2002). Zahalna teoriia derzhavy i prava [General theory of state and law]. Kharkiv: Pravo [in Ukrainian].

8. Zakon Ukrainy Pro zabezpechennia prav i svobod hromadian ta pravovyi rezhym na tymchasovo okupovanii terytorii Ukrainy [On Ensuring 
the Rights and Freedoms of Citizens and the Legal Regime in the Temporarily Occupied Territory of Ukraine]. (n.d.). zakon3.rada.gov.ua Retrieved from http://zakon3.rada.gov.ua/laws/show/1207-18 [in Ukrainian].

9. Kalmakaryan, R.A., \& Migachev, Y.I. (2004). Mezhdunarodnoe pravo [International law]. Moskov: Eksmo [in Russian].

10. Konventsiya o pravonarusheniyah i nekotoryih drugih deystviyah, sovershennyih na bortu vozdushnogo sudna [Convention on Offenses and Certain Other Acts Committed on Board Aircraft]. (n.d.). zakon4.rada.gov.ua. Retrieved from http://zakon4.rada.gov.ua/laws/show/995_244 [in Russian].

11. Konventsiia pro zakhyst tsyvilnoho naselennia pid chas viiny [Convention for the Protection of Civilian Persons in Time of War]. (n.d.). zakon5.rada.gov.ua. Retrieved from http://zakon5.rada.gov.ua/laws/show/ 995_154/print1459194719931410 [in Ukrainian].

12. Konventsiia Orhanizatsii Obiednanykh Natsii z morskoho prava [The United Nations Convention on Law of the Sea]. (n.d.). zakon4.rada.gov.ua Retrieved from http://zakon4.rada.gov.ua/laws/show/995_057 [in Ukrainian].

13. Konstytutsiia Ukrainy [Constitution of Ukraine]. 1996, June 28. Vidomosti Verkhovnoi Rady Ukrainy - Bulletin of the Verkhovna Rada of Ukraine. Kyiv: Parlam. vyd-vo [in Ukrainian].

14. Stashis, V.V., Taciy, V.Y. (Eds.). (2010). Kryminalne pravo Ukrainy: Zahalna chastyna [Criminal law of Ukraine: Common part]. Kharkiv: Pravo [in Ukrainian].

15. Malyarenko, V.T., Stashis, V.V., Taciy, V.Y. (Eds.). (2004). Kryminalnyi kodeks Ukrainy: naukovo-praktychnyi komentar [Criminal code of Ukraine: scientific and practical commentary]. Kharkiv: Odyssey [in Ukrainian].

16. Matsko, A. (2003) Mizhnarodne pravo [International Law]. Kyiv: MAUP [in Ukrainian].

17. Mezhdunarodnaya konventsiya ob unifikatsii nekotoryih pravil ob ugolovnoy yurisdiktsii po delam o stolknovenii sudov i drugih proisshestviy, svyazannyih s sudohodstvom [International Convention on the Unification of Certain Rules on Criminal Jurisdiction in Cases of Collisions and Other Accidents Related to Shipping] (n.d.). zakon1.rada.gov.ua Retrieved from http://zakon1.rada.gov.ua/laws/show/995_564 [in Ukrainian].

18. Ignatenko, G.V., \& Tiunov, O.I. (1999). Mezhdunarodnoe pravo [International law]. Moskov: NORMA - INFRA [in Russian].

19. Buromensky, M.V. (Eds.). (2006). Mizhnarodne pravo [International Law]. Kyiv: Yurinkom Inter [in Ukrainian].

20. Modelnyiy ugolovnyiy kodeks dlya gosudarstv - uchastnikov Sodruzhestva Nezavisimyih Gosudarstv [Model Penal Code for the Member States of the Commonwealth of Independent States]. Informatsionnyiy 
byuleten - Newsletter, 10. Retrieved from http://www.iacis.ru/html/?id= 22\&pag=30\&nid=1 [in Russian].

21. Moiseev, O.I. (2007) Kryminalno-pravova yurysdyktsiia Ukrainy shchodo zlochyniv, vchynenykh za yii mezhamy [Criminal Law Jurisdiction of Ukraine on Crimes Committed Outside It] Extended abstract of candidate's thesis. Kharkiv: Yaroslav Mudryi National Law University [in Ukrainian].

22. Andrushko, P.P. Honcharenko, V.H., Fesenko, Ye.V. (Eds.) (2009). Naukovo-praktychnyi komentar do Kryminalnoho kodeksu Ukrainy [Scientific and Practical Commentary to the Criminal Code of Ukraine]. Kyiv: Alerta ; KNT ; Tsentr uchbovoi literatury [in Ukrainian].

23. Melnyk, M.I., Khavroniuk, M.I. (Eds.). (2008) Naukovo-praktychnyi komentar do Kryminalnoho kodeksu Ukrainy [Scientific and Practical Commentary to the Criminal Code of Ukraine]. Kyiv: Yurydychna dumka Legal Opinion[in Ukrainian].

24. Panko, K.K. (2004) Metodologiya i teoriya zakonodatelnoy tehniki ugolovnogo prava Rossii [Methodology and theory of the legislative technique of criminal law in Russia]. Voronezh: Publishing house of Voronezh state University [in Russian].

25.Zakon Ukrainy Pro vykliuchnu (morsku) ekonomichnu zonu Ukrainy [On the exclusive (maritime) economic zone of Ukraine]. (1995, Maj 16). Vidomosti Verkhovnoi Rady Ukrainy - Bulletin of Verkhovna Rada of Ukraine. Kyiv: Parlam. vyd-vo [in Ukrainian].

26. Zakon Ukrainy Pro derzhavnyi kordon Ukrainy [On the State Border of Ukraine]. (1991, April 4). Vidomosti Verkhovnoi Rady Ukrainy - Bulletin of Verkhovna Rada of Ukraine. Kyiv: Parlam. vyd-vo [in Ukrainian].

27. Syroid, T.L. (2005). Mizhnarodne publichne pravo [Public International Law]. Kharkiv: Prometei-Pres [in Ukrainian].

28. Tagantsev, N. S. (1994). Russkoe ugolovnoe pravo [Russian criminal law]. Moskov: Nauka [in Russian].

29. Tkachevsky, Y.M., \& Safarov N.A. Tkachevskiy, Yu.M. (2005). Nekotoryie problemyi primeneniya universalnoy yurisdiktsii v mezhdunarodnom ugolovnom prave i natsionalnom zakonodatelstve [Some problems of the application of universal jurisdiction in international criminal law and national legislation]. Vesnik Mosk. un-ta. Ser 11. Pravo - Bulletin Mosk. un-ta. Vol 11. Law, 1, 27-47 [in Russian].

30. Kudryavtsev, V.N., Kelina, S.G. (Eds.). (1987). Ugolovnyiy zakon. Opyit teoreticheskogo modelirovaniya [Criminal law. The experience of theoretical modeling]. Moskov: Nauka [in Russian].

31. Yatsenko, S.S. (Eds.). (2003). Ugolovnyiy kodeks Ukrainyi: nauchnoprakticheskiy kommentariy [Criminal Code of Ukraine: scientific and practical commentary]. Kyiv: A.C.K. [in Ukrainian]. 
32. Khavroniuk, M.I. (2007). Kryminalne zakonodavstvo Ukrainy ta inshykh derzhav kontynentalnoi Yevropy: porivnialnyi analiz, problemy harmonizatsii [Criminal law of Ukraine and other continental European states: comparative analysis, problems of harmonization]. Extended abstract of Doctor's thesis. Kyiv: National Academy of Internal Affairs [in Ukrainian].

33. Malinin, V.B. (Eds.). (2005). Entsiklopediya ugolovnogo prava [Encyclopedia of Criminal Law]. SPb.: Izdanie professora Malinina [in Russian].

\section{Information about the author:} Oleksandr Zhytnyi, Doctor in Law, Professor, Head of Criminal and Legal Disciplines Department of the Law Faculty, V.N. Karazin Kharkiv National University

6, Svobody sq., Kharkiv, 61022, Ukraine ORCID ID: orcid.org/0000-0003-0795-626X 
NOTES 
NOTES 
Publishing house "Liha-Pres"

9 Kastelivka str., Lviv, 79012, Ukraine 44 Lubicka str., Torun, 87-100, Poland

Printed by the publishing house "Liha-Pres"

Passed for printing: November 25, 2019.

A run of 150 copies. 